IVANA SOARES PAIM

\title{
POR ENXERGAR DEMAIS. A PINTURA DE HUGO ADAMI
}

Universidade de São Paulo

Departamento de Artes Plásticas da Escola de Comunicação e Artes

SÃO PAULO/SP

2002 
IVANA SOARES PAIM

\section{POR ENXERGAR DEMAIS. A PINTURA DE HUGO ADAMI}

Dissertação apresentada ao departamento de Artes Plásticas da Escola de Comunicação e Artes da Universidade de São Paulo como exigência parcial para a obtenção do título de Mestre em História da Arte, sob a orientação do Prof. Dr. Domingos Tadeu Chiarelli

Universidade de São Paulo

Departamento de Artes Plásticas da Escola de Comunicação e Artes

SÃO PAULO/SP 


\section{POR ENXERGAR DEMAIS. A PINTURA DE HUGO ADAMI}

Banca julgadora:

Orientador:

Data:

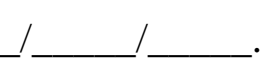

Universidade de São Paulo

Departamento de Artes Plásticas da Escola de Comunicação e Artes SÃO PAULO/SP 2002 


\section{AGRADECIMENTOS}

Agradeço à família do artista, aos colecionadores que gentilmente disponibilizaram suas coleções para este estudo. Ao pessoal do Museu Lasar Segall e do Instituto de Estudos Brasileiros da USP, como também aos funcionários do Museu de Arte Moderna de São Paulo, do Museu de Arte Contemporânea da USP, da Biblioteca Municipal Mário de Andrade, da biblioteca e arquivo da Faculdade de Direito do Largo de São Francisco da USP e da Sociarte, que foram tão prestativos.

Obrigada às pessoas que, de variadas maneiras, tanto contribuíram para a realização desta pesquisa: meus pais, Ana Thereza e Antônio, minha irmã Eliana e os amigos Roberto Grande Jr., Renata V. G. Rozestraten, Luciano Schinke, Rodrigo C. Cosentino, Maria Cecília Kunigk e Joaquim Nunes.

Agradeço especialmente a dedicação do professor orientador, Tadeu Chiarelli e a atenção e colaboração dos professores Helouise Costa, Lorenzo Mammi, Luciano Migliaccio e Mayra Laudanna. 
Dedico este trabalho à memória de Hugo Adami. 


\section{RESUMO}

Este estudo tem por objetivo contextualizar e esclarecer a importância da pintura do artista paulistano Hugo Adami para o Modernismo de São Paulo, como também, analisar esta produção entre o início da década de vinte e meados dos anos quarenta. A abordagem de sua pintura permeia questões como o Acadêmico, o Realismo, a pintura não-figurativa e as tendências de Retorno à Ordem, surgidas na Europa no período entre guerras. Esta monografia se propõe também a analisar o reflexo daquelas questões na arte brasileira e o reconhecimento de suas diretrizes nas pinturas de Adami, que seriam significativas para o desenvolvimento do projeto modernista de Mário de Andrade, em São Paulo, no final dos anos vinte. 
This monograph aims to contextualize and clarify the importance that Hugo Adami's paintings had to the development of Modernism in São Paulo. It also analyses his paintings produced within the beginning of the twenties and the middle forties. The study about Adami's paintings takes in account subjects such as the Academism, the Realism, the non-figurative painting and the Call to Order trends, which took place in Europe in the period between Wars. It considers as well, the way those movements were reflected on Brazilian Art and why the critic Mário de Andrade recognized in Adami's paintings the guiding lines he used to make his theories for Modernism in São Paulo, in the latest twenties. 
SUMÁRIO

INTRODUÇÃO: DUAS QUESTÕES SOBRE A PINTURA DE ADAMI

CAPÍTULO I - DO ACADÊMICO AO REALISMO, (EUROPA - BRASIL). AS PINTURAS INICIAIS DE

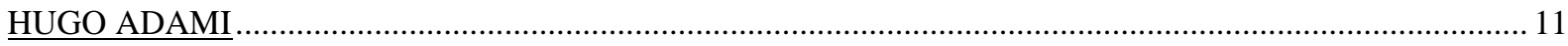

I.a. - Transformações do Acadêmico no Brasil e na Europa ………………………………............................ 12

I.b. - O desenvolvimento do Realismo e do Realismo/Naturalismo na França, Itália e Brasil até o início do

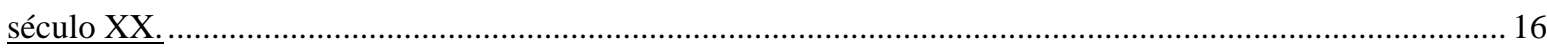

I.c. - Os primeiros professores de Adami e sua produção inicial ................................................................... 22

CAPÍTULO II - O NOVO REALISMO: O RETORNO À ORDEM E O NOVECENTO ITALIANO ……….... 27

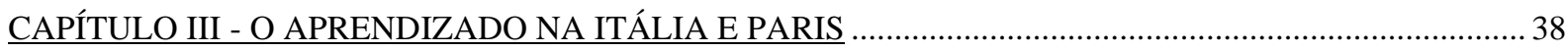

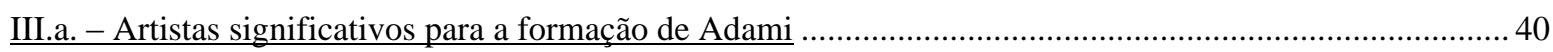

III.b. - Exposições na Europa e últimos anos na Itália e em Paris. ………………………………………….... 54

CAPÍTULO IV - A PINTURA DE HUGO ADAMI: NATUREZA-MORTA, PAISAGEM E RETRATO ..........57

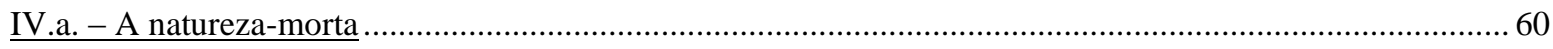

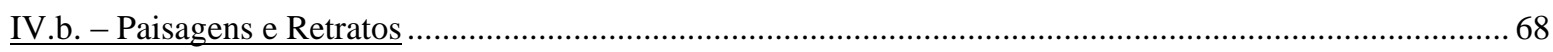

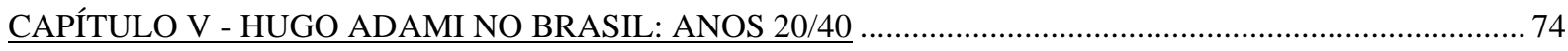

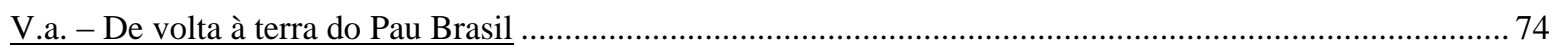

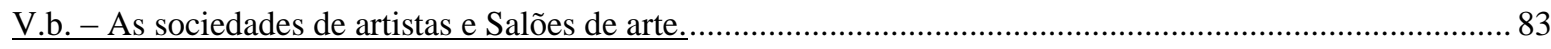

CONCLUSÃO

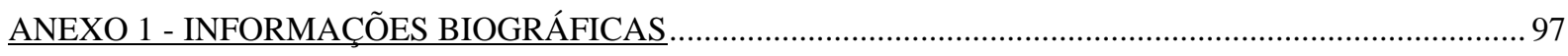

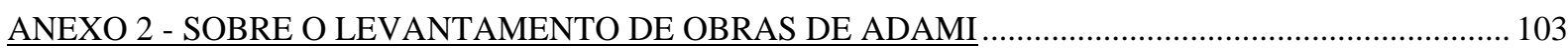

ANEXO 3 - LEVANTAMENTO PRELIMINAR DA OBRA DE HUGO ADAMI..................................... 105

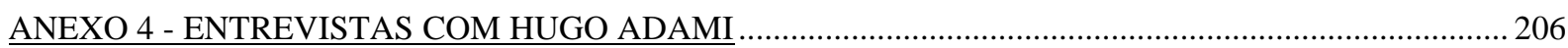

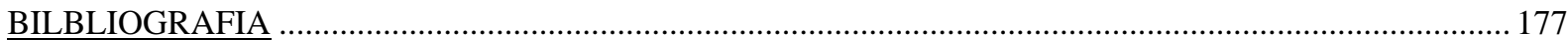




\section{INTRODUÇÃO: DUAS QUESTÕES SOBRE A PINTURA DE ADAMI}

Este estudo espera colocar a pintura de Adami em contexto e demonstrar sua relevância dentro do Modernismo paulistano, no período entre o início da década de vinte e meados da década de quarenta. Para tanto, foi necessário fazer um levantamento preliminar de suas obras afim de melhor caracterizar o conjunto de sua pintura.

Devido à atividade intensa do artista, não foi possível deixar de mencionar sua atuação junto às manifestações modernistas da época, como as associações de artistas e os salões.

Porém, antes de abordar propriamente o desenvolvimento de sua pintura no período mencionado, deve-se considerar e tentar esclarecer dois problemas que, de maneira geral, envolvem sua produção: em primeiro lugar, o longo período em que o artista permaneceu sem pintar; em segundo, a suposta vinculação de sua pintura ao que se convencionou chamar de arte acadêmica.

\section{O silêncio de Adami}

Hugo Adami, filho de italianos, mas nascido no Brasil, começou a pintar por volta de 1913, na Escola Profissional Masculina do Brás, e, quer neste país, (em São Paulo), quer na Itália, (Florença, Livorno, Sorrento), deu continuidade ao seu trabalho até 1945, aproximadamente. Depois dessa data, tendo já retornado de vez para seu país de nascimento, Adami parou de pintar, retomando essa atividade anos mais tarde, na década de setenta.

O crítico de arte Luiz Martins justificou tal silêncio do artista, relacionando-o à "onda abstracionista" que chegava aqui no Brasil na época, (logo seguida pela arte concreta e a pop) dando margem, supostamente, ao que o referido crítico chamou de "vigarice e aventureirismo" de alguns que, aproveitando da ignorância de outros, chegaram até: 
(...) ao absurdo da anti-arte - e por isso, não havia mais no Brasil de então, lugar para aqueles pintores que participaram da fase de renovação modernista da década de vinte: pintores pioneiros como Tarsila, Segall, Di Cavalcanti, etc, acharem que nada mais tinham a fazer nesse Carnaval de alegres e desenvoltos mascarados. (... $)^{1}$

Ao reler uma entrevista concedida por Adami em 1976, ${ }^{2}$ nota-se que, na verdade, o artista, ao decidir parar de pintar por volta de 1945, ainda não estava muito preocupado com a pintura não-figurativa que despontava no Brasil, naquela época. De fato, essa vertente só iria florescer no país no final da década de quarenta e começo dos anos cinqüenta. ${ }^{3}$

O que parece ter causado de início, o abandono dos pincéis por Adami foram, em primeiro lugar, questões de ordem pessoal, que o levavam a pensar sobre seu próprio fazer:

(...) parei de pintar porque numa certa hora comecei perceber que estava me repetindo, eu estava num beco sem saída (...) Vou parar e vou esperar que haja de novo um...uma razão, uma motivação, nem que seja através da evolução, da leitura, do convívio com as pessoas. (... $)^{4}$

Outro fato que o levou a cessar suas atividades pictóricas foi seu grande descontentamento ao ver, em São Paulo, as artes plásticas tomadas pela “onda cubista”, assim que chegou de volta ao Brasil, em 1940.

Foi exatamente naquele ano, com a exposição "Cento e Cinqüenta Anos de Pintura Francesa", que a geração modernista de 1930 teve um contato "vivo" com o trabalho dos principais artistas cubistas franceses.

Posteriormente, nos anos 1944 e 45, a Biblioteca Municipal começaria a importar livros de arte mais atualizados e a oferecer palestras sobre o Cubismo. Era significativo

\footnotetext{
${ }^{1}$ MARTINS, Luiz. “Hugo Adami”. O Estado de S. Paulo, 18/08/1976, p.12.

${ }^{2}$ Entrevista concedida por Hugo Adami ao artista Antônio Hélio Cabral no Museu Lasar Segall, São Paulo, março de 1976, fita a, p.8.

${ }^{3}$ GONÇALVES, Lisbeth Rebollo. Aldo Bonadei: o percurso de um pintor. São Paulo: Perspectiva, 1990, p.77.

${ }^{4}$ Entrevista concedida por Hugo Adami ao artista Antônio Hélio Cabral no Museu Lasar Segall, São Paulo, março de 1976, fita a., p.14.
} 
então, que a maioria dos artistas da geração de trinta começassem a pesquisar a linguagem cubista a partir da primeira metade dos anos quarenta. ${ }^{5}$

Sendo aquela linguagem pictórica totalmente avessa ao que Hugo Adami acreditava em arte - pois ia de encontro a toda sua formação realista - o artista afirmou ter perdido o entusiasmo pela pintura quando chegou aqui, e viu seus companheiros deixando-se levar pelo Cubismo.

$\mathrm{Na}$ época, Adami aconselhou vários artistas brasileiros a seguirem suas próprias linguagens e que evitassem o que chamava de pintura "encostada”, mera “cópia dos cubistas".

Dentre esses artistas aconselhados por Adami estavam: Cândido Portinari, Orlando Teruz, Dante Milano, Celso Antônio, Francisco Rebolo e Alfredo Volpi.

Porém, seu alvo de maiores críticas foi Portinari, chegando mesmo, certa vez, a desentender-se com ele. Quando Portinari expôs no Salão de Belas Artes do Rio, Hugo Adami - apesar de apreciar verdadeiramente o trabalho do colega e de ter ido ao almoço em sua homenagem pelo prêmio Pittisburg 6 - continuava a alertar o amigo sobre a maneira "errada" de se deixar influenciar por Picasso ou por outros pintores de vanguarda.

Tendo tido uma formação artística ligada ao Novecento Italiano, Adami não apreciava muito os pintores adotados por Portinari como Amedeo Modigliani e principalmente Pablo Picasso. Desse último, o pintor paulistano tinha até mesmo ojeriza. Em seu depoimento a Antônio Hélio Cabral, disse ser Picasso um artista fabuloso e charlatão ao mesmo tempo, por “encostar" seu trabalho naqueles de outros pintores, como Georges Braque ou Andrè Derain. Adami achava que Picasso só pararia de "copiar" outros pintores a partir de sua tela Mademoiseles D'Avignon. Mas o problema de Portinari, segundo ele, era “copiar” Picasso ao

\footnotetext{
${ }^{5}$ GONÇALVES, Lisbeth Rebollo. Aldo Bonadei: o percurso de um pintor. São Paulo: Perspectiva, 1990 , p.64.

${ }^{6}$ Almoço realizado em São Paulo para homenagear Portinari, devido à aquisição do prêmio internacional Pittisburg Exibition, promovido pelo Instituto Carnegie de Pittisburg. ZANINI, Walter. A Arte no Brasil nas décadas de1930 e 40. São Paulo: Instituto Walter Sales, s/d, p.64.
} 
extremo, a ponto de não ser capaz de desenvolver sua própria linguagem plástica. Adami dizia a Portinari:

(...) Picasso é um pintor que não se deve imitar, não se pode imitar, é uma bestialidade imitar. Pegue um primitivo qualquer, um puro qualquer, e ali você vai encontrar um filão para você se desenvolver, mas Picasso é a tua morte, ele te devora. Todo indivíduo que imitou Picasso não existe. Afirmo honestamente, Picasso fez um mal terrível, porque criou uma plêiade de artistas de todas as raças. Me lembro de japoneses imitando Picasso. Mas era tão Picasso que dava raiva. $(. . .)^{7}$

O que Adami parecia odiar no fato de Portinari se deixar "contaminar" por Picasso, não era apenas a anulação de uma linguagem "portinariana” própria, mais pessoal, mas o fato de Picasso e seu Cubismo Analítico não serem modelos aceitos pela sua formação novecentista. Tanto é que, como foi visto, recomendava Teruz e Portinari tomarem "qualquer primitivo ou puro" e partirem deles para constituírem suas linguagens próprias. O problema não era necessariamente o estabelecimento de um diálogo entre as pinturas daqueles artistas com aquela de Picasso, mas os resultados serem tão parecidos com a produção do último.

Adami relatou que ao voltar definitivamente ao Brasil em 1940, viu aqui a pintura se escravizando, se diluindo e se perdendo, tornando-se "encostada", naquela de Picasso e outros cubistas. Afirmou ter sido essa uma das razões que o levou a perder o interesse por pintar em meados da década de quarenta.

Se levarmos em consideração essas questões relativas ao pouco interesse de Adami pelo Cubismo e a elas aliarmos aquilo que escreveu o crítico Luiz Martins, veremos que, com a chegada do abstracionismo no Brasil, no final dos anos quarenta, todas aquelas dúvidas de Adami devem ter sido agravadas. Adami se questionava sobre os rumos que a pintura estava tomando no país e sobre sua própria postura como artista.

\footnotetext{
${ }^{7}$ Entrevista concedida por Hugo Adami ao artista Antônio Hélio Cabral no Museu Lasar Segall, São Paulo, março de 1976, fita b, p.12.
} 
Ele confrontou toda sua formação realista com aquela nova pintura, colocando em cheque suas convicções sobre o Realismo. Adami dizia ser muito "rígido" consigo mesmo e com seus colegas, no sentido de possuir uma preocupação constante em não deformar a imagem. Dizia também que, se talvez não tivesse sido assim tão duro consigo mesmo e com os outros, poderia ter continuado a pintar. ${ }^{8}$

Com essa afirmação, Adami mostrou que o conflito entre sua formação e a nova pintura o levaram a um impasse tão forte, que a única solução encontrada por ele, na época, foi o silêncio.

Depois de parar, não se sentia encorajado a voltar a pintar. Contudo, mesmo em silêncio, Adami nunca deixou de refletir sobre a pintura. Ficou refletindo, esperando o momento, a oportunidade de voltar a ela, caso aparecesse um motivo, uma razão que seria a resolução do impasse causado por aquele confronto de idéias.

Adami ressentia-se por não ter se permitido certas "deformações", por ter pintado sempre com o intelecto e a razão, chegando até mesmo a confessar, nos anos setenta, que teria desejado ser quase cego para que essa incapacidade física lhe permitisse - ou lhe obrigasse - a uma pintura mais solta, emocional..$^{9}$ Seu problema, dizia ele, era enxergar demais.

Então, em 1975, quando completava exatamente 75 anos de idade, a vida lhe deu essa oportunidade: naquele ano, o artista sofreu um deslocamento de retina que passou a lhe dificultar a visão. Nesta situação, começa a pintar novamente, produzindo paisagens em Campos do Jordão:

(...) só agora que eu pintei umas coisas (...), em Campos do Jordão. Mas quem sabe se agora seria interessante, agora que já não tenho mais olhos e as mãos não estão firmes, não é? Quem sabe se agora não é

\footnotetext{
${ }^{8}$ Ibidem, fita a., p.11.

${ }^{9}$ Ibidem, p. 10.
} 
interessante pegar de novo, não? Arrumar umas telas, começar a pintar outra vez, quem sabe se eu não vou atingir aquilo que eu achava que talvez conseguiria um dia, com menos vista, com menos, menos análise, não é? Menos perspicácia, não? (... $)^{10}$

Assim, “enxergar demais", como afirmou Adami, foi um dos motivos que o levou a não retomar a pintura antes de 1975. O artista só se permitiu recomeçar a produzir quando suas limitações físicas lhe ofereceram a oportunidade de buscar o que chamava de "certa deformação na figura". Ou seja, Hugo Adami pensou que sua limitação física libertaria seu olhar do Realismo, que julgava tão rígido, desde a década de quarenta. Esqueceu-se - talvez na ânsia de encontrar uma resposta para seu impasse - que o ato de ver não envolve apenas os olhos, mas também o pensamento. E seu pensamento continuava realista.

Portanto, embora criticasse sua própria rigidez ou fidelidade ao real, Adami, ao voltar a pintar nos anos setenta, não encaminhou seu trabalho totalmente para a pintura não-figurativa. Mesmo tendo, na década de oitenta, produzido uma ou outra paisagem distante da representação realista (figura 1), nunca pôde abandonar seu referencial: a natureza.

Não que fosse incapaz de compreender a pintura não-figurativa, como afirmou em uma entrevista em 1997, ${ }^{11}$ mas foi, na verdade, incapaz de aceita-la. Adami parece ter logrado um certo equilíbrio entre seu Realismo e a nova linguagem pictórica, sem, contudo, alcançar a deformação da figura. Conseguiu, porém, certa liberdade no uso da cor entre os anos oitenta e noventa.

Ao observar suas obras a partir da década de setenta, percebe-se também que Adami repetiu certos estilemas ou soluções compositivas, próprias aos seus quadros das décadas de vinte e trinta. Pintou naturezas-mortas e alguns retratos com um remoto aceno metafísico,

\footnotetext{
${ }^{10}$ Ibidem, p. 16.

${ }^{11}$ Adami demonstrava até certo repúdio à pintura não-figurativa ao dizer em tom contundente: "Pintura abstrata? Eu não entendo essa pintura". Na verdade, sua sentença soou mais como não aceitação do que incapacidade para compreende-la. Entrevista concedida por Hugo Adami a Maria Cecília Kunigk e à autora, em sua residência na Aclimação, São Paulo, outubro de 1997, p.2.
} 
como em "Natureza-Morta na Praia" (figura 2) e "Jardim da luz" (figura 3), onde adicionou elementos estranhos ao ambiente pintado, ou tentou criar, por meio da cor, uma atmosfera onírica.

No início daquela década, porém, abandona sua antiga preocupação com a cor, não alcançando resultados que o superassem, como nas telas de "Ubatuba" e "Campos do Jordão" (figura 4). Nessas pinturas de 1975, a combinação e organização de cores empobrecem, perdem o viço. Felizmente, no final da mesma década - até parar de pintar definitivamente em 1996 o artista recupera sua preocupação com a cor, utilizando-se de tons mais vibrantes, (principalmente em seus últimos quadros).

Suas pinturas da década de oitenta (figura 5), apresentam combinações de cores mais vivas como o rosa, laranja, amarelo e tons de azul que, apesar de contrastantes, apresentam-se em passagens sutis de um tom para outro, aliados a uma fatura ainda elaborada, mesmo com a "não firmeza" da mão.

Embora apresentasse uma composição com referências à realidade aparente, Adami já não finalizava o quadro por observação direta da natureza, mas recorria muitas vezes a anotações que fazia in loco ou de memória. ${ }^{12}$ Adami possuía blocos de folhas onde desenhava o que iria pintar e escrevia o nome das cores que usaria ao realizar o quadro.

À medida em que se aproximavam os anos noventa, aqueles contrastes de cor iriam se acentuando, tornando-se gritantes, mais brutos. Em algumas paisagens de montanhas, o céu amarelíssimo contrasta com os montes em azul ciano, ou aparecem faixas azuis num céu amarelo alaranjado. Um exemplo desse contraste seria a paisagem (figura 6). A filha adotiva do artista, Rosa Adami, em entrevista concedida à autora, declarou estar ele muito apegado,

\footnotetext{
${ }^{12}$ Entrevista concedida pela Profa. Dra. Mayra Laudana à autora, no Instituto de Estudos Brasileiros da USP (IEB), São Paulo, junho de 2001.
} 
nos últimos anos em que pintou, a um livro grosso de capa dura que falava sobre os fauvistas: Fauvismus: biographisch-kritische studie, de Jean Leymarie. ${ }^{13}$

Assim, embora tivesse trazido para suas pinturas inovações na cor, a estrutura formal de suas figuras continuava ligada ao real aparente. Adami não parece ter resolvido totalmente seu impasse: encontrar um equilíbrio maior entre sua figuração realista, "rígida" e a liberdade oferecida pela pintura não-figurativa.

Com o passar do tempo, sua resolução formal foi se enfraquecendo, tornando-se menos inteira. Não se vê em suas últimas pinturas a "deformação" tão desejada para a resolução formal, mas apenas o peso da idade. As últimas telas mostram pinturas desgastadas, umas até meio toscas, inacabadas...

Mesmo tendo direcionado seu tratamento da cor para uma solução mais vibrante, não chegou a acompanhar o passo da evolução das artes plásticas no país. Essas três últimas décadas de sua pintura devem ser examinadas dentro da busca individual do artista de uma solução para o impasse causado pela pintura não-figurativa e sua formação realista. Adami manteve-se à parte das descobertas e debates artísticos em artes desde os anos cinqüenta e sessenta, por estarem muito distantes de sua formação.

\section{Adami e o Acadêmico}

A segunda questão sobre a pintura de Hugo Adami cai no perigo de associa-la ao que a crítica, de uma maneira geral, define como Acadêmico.

Há uma contradição entre a opinião dos críticos Mário Barata e Luiz Martins, e a da estudiosa Vera D'Horta, quanto à sua produção. Os dois primeiros não classificam a pintura

\footnotetext{
${ }^{13}$ Entrevista concedida por Rosa Adami, filha adotiva do artista à autora, em sua residência na Aclimação, São Paulo, agosto de 2000.
} 
de Hugo Adami como acadêmica, colocando-a mesmo como reação àquele tipo de pintura. Já Vera D’Horta, define os trabalhos de Adami como partidários do "Acadêmico". ${ }^{14}$

O que Mário Barata e Luiz Martins chamaram de Acadêmico foi, na verdade, uma pintura sob orientação do Realismo/Naturalismo, já desgastada pelo gosto burguês da oligarquia cafeeira em São Paulo, no início do século XX. Mário Barata afirma que a importância de Adami se deveu ao fato do artista ter introduzido no Brasil, um novo tipo de natureza-morta e paisagens que iam contra esse tipo de pintura "academicista".

Em “Hugo Adami”, texto de Luiz Martins, publicado no jornal O Estado de S. Paulo, em 1976, o artista é colocado entre aqueles que lutaram contra o "passadismo acadêmico" no Brasil, na década de vinte.

Já em seu texto, “Três bons artistas e uma sugestão aos jovens”, Vera D’Horta afirma haver em toda a pintura de Adami, até a década de quarenta, traços da pintura acadêmica e coloca num mesmo patamar as telas do início dos anos vinte, "Velha Bretã", "Frango", (figura 7) e aquelas de sua fase italiana, "Natureza-Morta com garrafão", "Natureza-Morta com faisões", (figura 8) e “As artes” (figura 24), como se orientadas por um mesmo princípio:

(...) Na escolha dos temas (Natureza-Morta com garrafão, A velha bretã, Frango, As artes, NaturezaMorta com Faisões, etc); suas telas mostram vínculos fortes com o academicismo, enquanto que a fatura é vigorosa, sua textura dá existência individual aos objetos retratados. Realidade, ideal acadêmico, não refletem um todo harmonioso. $(\ldots)^{15}$

$\mathrm{Na}$ verdade, as obras de Adami produzidas a partir de sua fase italiana não receberam influência do Acadêmico, mas de artistas vinculados ao Realismo do Novecento Italiano, um

\footnotetext{
${ }^{14}$ BARATA, Mário. "Época e Visualidade na pintura de Hugo Adami”. In Hugo Adami, Museu de Arte Moderna de São Paulo, 1986, p.1. D’HORTA, Vera. "Três bons artistas e uma sugestão aos jovens”. Folha de São Paulo, Ilustrada. São Paulo, s/d p.19. MARTINS, Luiz. "Hugo Adami”. O Estado de São Paulo, 18/08/1976, p.12.

${ }^{15}$ D’Horta, Vera “Três bons artistas e uma sugestão aos jovens”. Folha de S. Paulo, Ilustrada. São Paulo, s/d, p.19.
} 
movimento de Retorno à Ordem, ocorrido na Itália no período entre guerras, que nada buscou na pintura acadêmica do século XIX. ${ }^{16}$

Além do mais, a pintura que vigorava no Brasil, na época em que Adami começou a pintar, não era mais orientada por um ideal acadêmico, mas por elementos da pintura realista/naturalista. Assim, tanto sua produção inicial - anterior a 1923 - como suas telas do período em que viveu na Itália e sua produção posterior no Brasil não tiveram influência do "Acadêmico".

Para melhor compreender o distanciamento da pintura de Adami daquilo que se convencionou chamar de "Acadêmico", assim como os pressupostos realistas pelos quais toda sua pintura se orientou, serão estudadas no Capítulo I, questões sobre o desenvolvimento do Acadêmico e do Realismo na Europa e seus desdobramentos no Brasil.

O Capítulo II, abordará o aparecimento de um novo Realismo no período do entre guerras na Europa em geral e na Itália com o Novecento. Os capítulos seguintes, tratarão da formação de Hugo Adami na Europa, da caracterização de sua pintura dentro desse novo Realismo e por fim, a recepção da mesma dentro do Modernismo paulista no final dos anos vinte.

${ }^{16}$ Esse assunto será tratado com mais detalhes nos Capítulos II e III desta dissertação. 


\section{CAPÍTULO I}

\section{DO ACADÊMICO AO REALISMO, (EUROPA - BRASIL). AS PINTURAS INICIAIS DE HUGO ADAMI}

A fim de melhor esclarecer a diferença entre a arte acadêmica e a realista/naturalista no Brasil, é necessário identificar como a arte acadêmica e a pintura realista/naturalista se desenvolveram na Europa e aqui, além de mostrar sob quais aspectos os movimentos nesses dois locais se diferenciavam. Mas antes de entrar diretamente nesse estudo, resta atentar para a escolha do termo Realismo/Naturalismo feita para essa pesquisa e suas razões.

Ao se pronunciar sobre as vertentes artísticas posteriores ao Romantismo e anteriores ao Impressionismo, o historiador inglês Arnold Hauser considerou o Naturalismo uma vertente artística estritamente plástica, preocupada apenas com a verossimilhança na elaboração da imagem pictórica. Já o Realismo, na opinião do autor, seria uma orientação filosófica, surgida no final do século XIX, opositora ao Romantismo, onde cabia também a preocupação social. ${ }^{17}$

Já a historiadora norte-americana Linda Nochlin não se utiliza do termo Naturalismo para falar de questões do Realismo, mas, nele reconhece também, a preocupação com as causas sociais. ${ }^{18}$

Por sua vez, o pesquisador norte-americano Paul Wood, chama aquele movimento de Realismo/Naturalismo, por ser clara a sua preocupação com o entorno, deixando o termo Realismo, apenas para se referir à obra engajada socialmente do pintor francês Gustave Courbet. ${ }^{19}$

\footnotetext{
${ }^{17}$ HAUSER, Arnold. História Social da Literatura e da Arte. Rio de Janeiro: Mestre Jou, 1982, p.944.

${ }^{18}$ NOCHLIN, Linda. Realism: style and civilization. New York/Baltimore: Penguin Inc., 1976, p.19.

${ }^{19}$ WOOD, Paul. In FER, Briony et. al. Realismo, Racionalismo, Surrealismo. São Paulo: Cosac \& Naify, 1998, p.10.
} 
Por englobar a preocupação com o entorno vinda do Naturalismo e devido àsconseqüências dessa preocupação na definição de um novo rumo para a arte na segunda metade do século XIX - descartando finalmente o Acadêmico - o termo dado por Wood àquela vertente foi aqui adotado. Essa abordagem será igualmente útil para diferenciar essa tendência específica do século XIX, dos diferentes tipos de Realismo que aparecerão na cena internacional no século passado, vistos no Capítulo II desta dissertação.

\section{I.a. - Transformações do Acadêmico no Brasil e na Europa}

No Brasil, por menos aristocráticos que tenham sido o primeiro e o segundo impérios, e por mais presa a valores burgueses que tenha sido a produção artística local naquela época, sem sombra de dúvida, alguns pintores possuíam muito daquele caráter pragmático da arte acadêmica européia, que sempre visou a glorificação do rei e da nobreza, criando símbolos por meio da pintura e outras modalidades.

Pedro Américo e Vítor Meireles foram os grandes acadêmicos encarregados de criar os principais símbolos do II Império.

Como é sabido, na França, a Academia - aparelho de Estado a serviço da realeza privilegiava a pintura histórica ou alegórica porque essa aproximaria o homem de Deus, através das imagens de reis, príncipes e heróis mitológicos. Os outros gêneros pictóricos, como a pintura de animais, paisagens e naturezas-mortas eram tidos como menos importantes ou menores, pois se afastavam da maior obra divina que era o corpo humano. ${ }^{20}$

Segundo o historiador Nikolaus Pevsner, um princípio acadêmico importante, era o desprezo a todos esses gêneros chamados menores, ou seja, qualquer coisa cujo título não começasse por Histoire. Pevsner cita o livro do teórico acadêmico francês, do século XVII,

\footnotetext{
${ }^{20}$ PEVSNER, Nikolaus. Academias de Arte: pasado y presente. Madrid: Cátedra, 1982, p.73.
} 
André Félibien, no qual encontram-se algumas escalas de valor segundo os temas do quadro e que influenciaram em grande medida as gerações seguintes. ${ }^{21}$

Nesse texto, Félibien afirmava que as naturezas-mortas estão no final da escala, sendo as paisagens mais apreciadas que elas e estando ainda num posto superior, as figuras de animais, já que tratam de uma forma de vida julgada superior à vegetal. A humanidade, por sua vez, seria superior aos animais e, assim, o retrato de uma pessoa seria mais valioso que uma imagem de animal. Contudo, a História estaria no topo dessa hierarquia, considerada muito mais importante que a apresentação realista de seres individuais em situações cotidianas, banais. ${ }^{22}$

A síntese do pensamento acadêmico francês, fornecida por Pevsner, ao indicar a supremacia que o assunto dito nobre devia possuir em qualquer obra de arte, aponta para a importância dada à Antiguidade como parâmetro para a elaboração de obras de arte. Tudo deveria estar submetido aos seus cânones, todos os elementos da obra deviam obedecê-los. Até a paisagem a ser retratada, tinha que adequar-se ao padrão da paisagem romana, tida como a "mais perfeita". ${ }^{23}$ A pintura, por sua vez, teria que estar vinculada ao desenho, em detrimento da cor, o que ressaltava seu caráter retórico, narrativo, ligado ao historicismo acadêmico. ${ }^{24}$

Contra esses cânones acadêmicos tão restritos, iriam aparecer os ideólogos da burguesia, trazendo consigo uma nova postura perante a arte. Segundo o estudioso Tadeu Chiarelli, um dos primeiros sintomas dessa mudança, na França, acontece na hierarquia dos

\footnotetext{
${ }^{21}$ O livro de Félibien ao qual Nikolaus Pevsner refere é, Entretiens sur les viés et sur les ouvrages des plus excellens peintres anciens et modernes, Paris, 1666 - 1688. Esta obra foi reeditada com o título: Félibibien's Life of Poussin. Comentários de Claire Pace. Londres: Thames \& Hudson, 1981.

${ }^{22}$ PEVSNER, Nikolaus. Academias de Arte: pasado y presente. Madrid: Cátedra, 1982, p.75.

${ }^{23}$ Ibidem, p.76.

${ }^{24}$ LICHTENSTEIN, Jacqueline. A cor eloqüente. São Paulo: Siciliano, 1994, p.38.
} 
gêneros pictóricos, quando a pintura de história começa a ser substituída naquele país pela pintura de gênero histórico. ${ }^{25}$

Esse gênero de pintura tirava o ideal da pintura de história, repudiando sua antiga grandiloqüência em prol de um prosaísmo do cotidiano, favorecendo já os ideais da classe burguesa, bem fortalecida no século XIX.

As batalhas representadas por Antoine Jean J. Gros, (figura 9) seriam um bom exemplo de pintura de gênero histórico, pois mostram uma nova concepção moral sobre o assunto "guerra". Foi ele o primeiro artista a representar batalhas de um ponto de vista humanitário, e a revelar-lhes aspectos não tão espetaculares. ${ }^{26}$

De acordo com o historiador Félix Ferreira, aqui no Brasil, no final do século XIX, o público já não estava mais afeito às heroicidades de "Riachuelo" e "Avaí" de Pedro Américo, da mesma forma que, na França, ao público parisiense dos anos trinta já não interessava a exaltação dos heróis franceses. ${ }^{27}$

Assim, contra a arte acadêmica, pelo qual a aristocracia tomava seus direitos de comando, enaltecendo seus heróis, surge, em contrapartida, a perspectiva burguesa, que propunha exatamente a retomada de uma pintura que mostrasse o cotidiano, que descrevesse o interior das casas e seus objetos, como também a vida das pessoas dessa classe. Assim, para a burguesia, não interessavam mais heroísmos e deuses, mas o cotidiano, a vida "comum". Esta seria, portanto, uma das principais razões para que os gêneros paisagem e natureza-morta vigorassem, em detrimento da pintura que exaltava símbolos e entusiasmos nacionais.

Mas o grande golpe que a hierarquia dos gêneros iria receber na França viria com Gustave Courbet, mais tarde considerado pai do Realismo na pintura. Suas telas "Os britadores de pedras", (figura 10) e "Funeral em Ornans", representam um marco na história

\footnotetext{
${ }^{25}$ CHIARELLI, Tadeu. De Almeida Jr. a Almeida Jr. Tese de doutorado. São Paulo: ECA/USP,1996, p.259.

${ }^{26}$ HAUSER, Arnold. História Social da Literatura e da Arte. Rio de Janeiro: Mestre Jou, 1985, v. II, p.805.

${ }^{27}$ CHIARELLI, Tadeu. De Almeida Jr. a Almeida Jr. Tese de doutorado. São Paulo: ECA/USP, 1996, p.259.
} 
ocidental. Nelas, pela primeira vez, um pintor ousava tomar telas de proporções consideráveis - destinadas tradicionalmente, apenas aos motivos históricos - para mostrar pessoas do povo, pequenos burgueses do interior, proletários, subproletários e camponeses.

A linguagem pictórica de Courbet igualmente rechaçava os clichês da tradição acadêmica, pois o artista buscava a visualidade popular para embasar a sua própria. E, embora sua obra, em seu compromisso com a realidade social francesa, tenha sido a mais radical entre todas, não foi a única a ir contra aqueles ideais acadêmicos.

Nas cenas inglesa e francesa já era possível perceber um interesse crescente de certos artistas em eleger paisagens campestres ou suburbanas, trabalhadores e pobres, como Honoré Daumier ou Jean François Millet. ${ }^{28}$ Assim, essa pintura realista elevava a antiga pintura de "cenas de gênero" ao status das antigas pinturas de história, assumindo o papel principal na escala de valores de uma parte considerável de artistas franceses, papel este que seria aceito pelo público burguês da época (não sem alguma polêmica), tanto na França quanto no restante do mundo ocidental.

${ }^{28}$ Ibidem, p.260. 
I.b. - O desenvolvimento do Realismo e do Realismo/Naturalismo na França, Itália e Brasil até o início do século XX.

No entanto, segundo a historiadora Linda Nochlin, o Realismo foi muito mais do que uma mudança hierárquica dos gêneros na pintura. A autora o considera como uma atitude estética que surgiu no final do século XVIII com a pintura de gênero histórico, citada há pouco, tendo florescido propriamente com o Realismo/Naturalismo no final do século XIX, desdobrando-se no movimento Impressionista e renascendo com novas características durante o período entre guerras. ${ }^{29}$ Considerar o Realismo como atitude estética, facilitará a compreensão das correntes realistas que aparecerão no século XX.

A autora citada, afirma que uma das maiores conquistas do Realismo na pintura foi superar o modelo ou esquema acadêmico existente entre o artista e a captação da natureza em seus trabalhos, o que se deu plenamente no final do século XIX com o movimento realista/naturalista. Quando o pintor inglês John Constable afirmou, em 1882, que ao sentar-se para pintar tentava se esquecer que já tivesse visto outros quadros, queria na verdade despir sua mente de todo conhecimento de fórmulas preconcebidas para a pintura e ter assim, um contato direto com a natureza. ${ }^{30}$

A fidelidade à percepção da realidade visual foi apenas um aspecto da empreitada realista/naturalista. Segundo Nochlin seria errôneo basear a concepção de tão complexo movimento, somente na verossimilhança. A autora afirma que para compreendê-lo com mais abrangência, deve se levar em conta duas de suas contribuições para o desenvolvimento da arte no século XIX: uma delas seria a conexão feita pelos realistas/naturalistas entre história e fato experienciado. Isto é, o verdadeiro entendimento e representação de ambos, passado

\footnotetext{
${ }^{29}$ NOCHLIN, Linda. Realism: style and civilization. New York/Baltimore: Penguin Inc., 1976, p.23.

${ }^{30}$ Ibidem, p. 26.
} 
e presente, passaria a depender de um escrupuloso exame da evidência; livre de qualquer avaliação convencional, moral ou metafísica. Em 1861 Courbet declarava que a pintura era essencialmente uma arte concreta e podia somente consistir na apresentação de coisas reais e existentes. Portanto, um objeto que não fosse visível, não existente no mundo físico, não seria digno da pintura. Esse pressuposto leva assim, à outra contribuição do movimento realista/naturalista: a contemporaneidade. Ora, se para os realistas como Courbet, o artista devia pintar apenas o que encontrasse à sua volta, isso significaria considerar o presente em que vivia. Assim, os realistas/naturalistas do final do século XIX não viam mais porque pintar fatos do passado ou futuro.

O crítico francês Jules Antoine Castagnary definiu claramente essa “contemporaneidade" eleita por aqueles artistas: "os naturalistas colocaram o artista de volta em sua própria era, com a missão de refleti-la (...) descrevem a aparência da própria sociedade e seus costumes e não mais aqueles das civilizações há muito desaparecidas". ${ }^{31}$

Na medida em que esse o Realismo/Naturalismo desenvolvia-se no final do século XIX, a demanda por contemporaneidade tornava-se mais rigorosa. A “instantaneidade" dos impressionistas era a "contemporaneidade" levada aos seus últimos limites. O "agora", o "hoje", o "presente", tornavam-se "este instante".

Sem dúvida, continua Nochlin, a fotografia ajudou a criar esta identificação do contemporâneo com o instantâneo, levando o poeta Baudelaire a afirmar: "A Modernidade é o transitório, o fugidio, o contingente". ${ }^{32}$ Assim, essa insistência de apreender o momento presente na arte foi um aspecto essencial para entender o desdobramento do Realismo/Naturalismo dentro de um "Realismo impressionista", na França. A captação do movimento passa a ser compreendida no "agora", num flash de visão.

\footnotetext{
${ }^{31}$ Ibidem, p.28.

32 Ibidem, p. 29.
} 
Na Itália, o Realismo/Naturalismo se desenvolveu de maneira eclética, onde ainda sobreviviam reminiscências classicistas e românticas.

No final do século XIX, a Itália passava por um período de unificação política, territorial e nacional, campo fértil para o desenvolvimento de idéias ligadas ao Realismo/Naturalismo. Mas ainda era um país fragmentado, não totalmente coeso, tanto no sentido político quanto ideológico. Daí ocorrerem concomitantemente orientações artísticas tão antagônicas dentro de um mesmo território. Foram postos assim, sob um mesmo ponto de vista, a fidelidade ótica, o historicismo romântico, a nova temática realista e o tema idealizado e edificante. É esse ecletismo, portanto, que explica como depois de florescer entre os anos de 1855 e 1877, a objetiva fidelidade ótica se reduziria a um divisionismo puramente ótico e decorativo e a temática realista agregaria em si um historicismo romântico levando a uma pintura cenográfica e até mesmo arqueológica no início do século XX. ${ }^{33}$

Mas, voltando ao início do século XIX, na Itália, o Realismo/Naturalismo surgiria como a "revolução da macchia", ou mancha de tinta, constituindo o que se chamou de movimento dos macchiaioli. Seus maiores expoentes foram: Giuseppe Abbati, Silvestro Lega, Telemaco Signorini e Giovanni Fattori, (figura 11). Esses pintores privilegiavam a busca da forma na pintura por meio da mancha de cor. ${ }^{34}$ Tal movimento, porém, não investiu somente na transformação da técnica ou da forma, mas, também do tema, do relacionamento humano e da postura dos artistas perante as coisas. Assinalou em toda a Itália, não só o término da linha e do desenho acadêmico, mas também, o fim da pintura escura, betuminosa.

Mesmo que por breve tempo, marcou igualmente o fim da pintura religiosa enquanto suscetível de constituir obra de arte e o aparecimento da caricatura moderna na Itália, com

\footnotetext{
${ }^{33}$ MALTESE, Corrado.Storia dell'arte in Itália: 1785 - 1943. Torino: Einaudi, 1992, p.171.

${ }^{34}$ Seria importante lembrar que segundo alguns críticos italianos como Bargelini e Argan, esses paisagistas italianos diferenciavam-se dos impressionistas, no que diz respeito ao uso da cor. Os impressionistas utilizavam a cor para chegar à sensações de luminosidade, já os macchiaioli a utilizavam como mancha, ou macchia, para chegarem à forma. BARGELINI, Piero. Il café Michelangiolo. Firenze: Vallechi, 1944, p.198.
} 
expressão de liberdade crítica e auto-crítica dos novos grupos sociais. Demarcou, assim, a afirmação da possibilidade humana de conhecer o mundo em toda sua consistência objetiva por meio da observação e experiência direta da natureza que era, no fundo, a essência do movimento macchiaiolo. Mas, segundo Maltese, devido à falta de uma elaboração teórica mais coesa na Itália, o movimento perdeu-se na busca vazia de efeitos de luz e cor, chamada de divisionismo ou numa retomada do historicismo romântico, indo desdobrar-se mais tarde numa pintura simbolista, meramente cenográfica. ${ }^{35}$

Maltese afirma que tanto na França, quanto na Itália, o Realismo iria desembocar na pintura divisionista, derivada do Impressionismo no primeiro país e dos macchiaioli, no segundo. $\mathrm{O}$ autor continua dizendo que também na França, a pintura histórico-romântica renasceria num curioso "setecentismo" concentrado na pintura de Meissonier, dando margem a um virtuosismo exagerado, apreciado por uma burguesia de gosto duvidoso. Seria contra esses tipos de pintura que as vanguardas iriam se rebelar no início do século XX. Mas por hora, não deve ser esquecida a importância que o Realismo/Naturalismo teve para "afugentar" da pintura os cânones acadêmicos, valorizando a observação direta da natureza.

No Brasil, foi exatamente essa possibilidade de olhar e valorizar o entorno que chamou a atenção de artistas brasileiros ou residentes no país - como Jorge Grimm, entre outros -, interessados em uma arte alternativa para o país que desse conta de suas peculiaridades físicas e humanas..$^{36}$

Com as lutas pela proclamação da República no final do século XIX, surgiu no Brasil, entre os artistas e a crítica, a necessidade de ir contra a produção da Academia Imperial, tida como espelho do atraso do Império em relação às artes. Assim, adotaram a estética naturalista

\footnotetext{
${ }^{35}$ MALTESE, Corrado. Storia dell'arte in Itália: 1785 - 1943. Torino: Einaudi, 1992, p.225.

${ }^{36}$ CHIARELLI, Tadeu. Um Jeca nos Vernissages. São Paulo: EDUSP, 1995, p. 82.
} 
como uma forma de oposição àquela situação. O Realismo/Naturalismo foi mesclado então a ideais nacionalistas, pois entrava no Brasil, em um período de transição de governos.

O primeiro pintor brasileiro ligado ao Realismo/Naturalismo foi Almeida Jr. Retratou caipiras e pequeno-burgueses em cenas cotidianas. Contudo, apesar de seu apego a representação naturalista, Almeida Jr., segundo Chiarelli, parece não ter pretendido, de fato, abrir uma tradição nova na arte brasileira. Seu Realismo/Naturalismo diferenciava daquele de Courbet ou Millet porque não mostrava em suas telas os habitantes do interior desenvolvendo atividades produtivas - onde ficasse patente seu envolvimento com a terra, com a produção de riquezas - mostrava-os apenas em atividades de laser ou repouso.

Embora no geral, o Realismo/Naturalismo no Brasil tenha carregado alguns resquícios da arte acadêmica, dela já se havia distanciado e a ela se opunha oficialmente, como esclarece Chiarelli:

(...) Com as lutas pela proclamação da República, surgiu no Brasil uma vertente da crítica que, vendo na produção veiculada pela Academia Imperial de Belas Artes os índices do atraso do Império em relação às artes, adotará a valorização da estética naturalista e o apoio a artistas a ela ligada, como mais uma forma de oposição ao status quo. Será essa oposição que de fato irá instaurar o debate artístico no Brasil, propondo uma arte alternativa para o país, uma arte que desse conta de suas peculiaridades físicas e humanas. (...) ${ }^{37}$

Neste trecho, Chiarelli caracteriza o tipo de produção pictórica que havia desde o final do século XIX no Brasil, chamando atenção para o Naturalismo, devido à vontade de uma parcela da crítica da época de caracterizar aspectos da vida cotidiana, ou do povo brasileiro, na busca de uma identidade nacional.

Nas linhas seguintes, o autor atenta para a falta de clareza dos intelectuais da época para definirem puramente esse Naturalismo, sendo ele ainda carregado de certos resíduos acadêmicos. No entanto afirma que "tal fato não impediu que esse segmento se caracterizasse

\footnotetext{
${ }^{37}$ CHIARELLI, Tadeu. Um jeca nos vernissages. São Paulo: EDUSP, 1995, p.82.
} 
como opositor à oficialidade e detentor de valores de cunho naturalista". ${ }^{38}$ Segundo o autor, será dentro desse Naturalismo que surgiriam as contribuições mais contundentes de oposição à arte oficial ou acadêmica, caracterizado por uma representação realista/naturalista, que privilegiava a observação do entorno e a cor local do país. Vê-se que tanto na França como no Brasil, essa arte se virou contra a Academia; e no Brasil, foi associada à busca de uma identidade nacional.

No Brasil, assim como ocorreu nos países acima citados, o Realismo/Naturalismo iria diluir-se numa pintura retórica, comprometida com o gosto da burguesia cafeeira, repudiada por Mário de Andrade e seus seguidores modernistas na década de XX.

${ }^{38}$ Ibidem, p.83. 
I.c. - Os primeiros professores de Adami e sua produção inicial

Ao iniciar suas atividades pictóricas, Adami teve contato com esse Realismo/Naturalismo, já distante do gosto acadêmico. Mesmo porque, como será visto, os primeiros professores de Adami - Giuseppe Barchitta e Alfredo Norfini - entrosavam-se já com a pintura do grupo de artistas italianos do século XIX, os macchiaioli, que não apresentava nada de acadêmico, pois valorizavam a construção da forma por meio de massas de cor, como visto há pouco. E existiria um outro motivo para que Adami não pudesse ter recebido uma orientação acadêmica no início de sua formação. Além de Barchitta e Norfini, é importante não se esquecer de J. Fischer Elpons, com quem o então jovem pintor também estudou. Elpons desenvolvia um trabalho bastante distanciado, igualmente, do gosto acadêmico.

\section{Giuseppe Barchitta}

Giuseppe Barchitta, natural de Cattania, Itália, radicado em São Paulo, em 1911, havia participado da I Exposição de Belas Artes na cidade de São Paulo e, em 1913, já lecionava na Escola Profissionalizante Masculina do Brás, onde teve como alunos César Lacanna, Aldo Malagoli, Otávio Araújo e Hugo Adami. ${ }^{39}$

Fez seu aprendizado no Instituto de Belas Artes de Roma, tendo pintado as telas: "Madonna della Salute" e "Sagrada Família", na igreja de San Giuseppe em Cattania. ${ }^{40}$ Mais tarde, passa pela formação divisionista da pintura macchiaioli e apresentaria a seus alunos no Brasil, as pinceladas nervosas e a prioridade da cor pura. ${ }^{41}$ Era admirador de Cézanne, Pelliza

\footnotetext{
${ }^{39}$ LEITE, José Roberto Teixeira. Dicionário crítico da pintura no Brasil. Rio de Janeiro: Artlivre, 1988.

${ }^{40}$ CONSOLI,T. Chiesa di San Giuseppe.http:/www. Scordia nell Sito della Chiesa di San Giuseppe.com.it [Scordia della Província], s/d.

${ }^{41}$ LEITE, José Roberto Teixeira. Dicionário crítico da pintura no Brasil. Rio de Janeiro: Artlivre, 1988.
} 
da Volpedo, Segantini e Previati, ${ }^{42}$ pintores que nada tinham de acadêmico. Assim, embora tivesse uma pintura naturalista, próxima ao real, sua orientação jamais poderia ter privilegiado os ideais da Academia.

Adami foi seu aluno na Escola Profissional Masculina do Brás, entre 1911 e 1913, aproximadamente.

\section{Alfredo Norfini (1867 - 1944)}

Embora tenha tido formação na Academia de Belas Artes de Lucca, Alfredo Norfini desenvolveu um tratamento da cor e composição livre das regras acadêmicas. Para seus quadros, valorizava mais a paisagem, retratos e cenas cotidianas.

A pesquisadora Ruth Tarasantchi afirma ter sido Norfini, um bom animalista, “especialmente quando se tratava de cavalos, dos quais capta o movimento". ${ }^{43}$ Diz igualmente a autora que, ao usar a aquarela, seus traços eram rápidos com cores leves e que, grande ou pequena, sua pincelada era espontânea. $\mathrm{O}$ forte de seu trabalho, segundo ainda a estudiosa, era a cor quente, macia e viva, denotando sua preocupação em ser fiel à cor local, também deixando espaço para a imaginação. ${ }^{44}$

Norfini foi um importante documentarista, principalmente de paisagens das cidades brasileiras, como Rio de Janeiro e as cidades barrocas de Minas Gerais, como também de pessoas de diferentes povos, já que viajou muito, recolhendo de cada local visitado, composições vivas e realistas.

Na pintura a óleo, seu trabalho nem sempre alcançou resultados tão espontâneos e vibrantes como em suas aquarelas. ${ }^{45}$ A composição parece perder movimento e as figuras ganham certa

\footnotetext{
42 Ibidem.

43. TARASANTCHI, Ruth S. Pintores paisagistas em São Paulo $(1890-1920)$. Tese de doutorado. São Paulo: ECA/USP, 1986, p.233.

${ }^{44}$ Ibidem, p. 232.

45 Ibidem, p.230.
} 
rigidez; mas, apesar de contornar as figuras no óleo e, algumas vezes, deixar parecer o traço sutil do lápis com que foi feito o desenho, Tarasantchi assegura que isto não interfere na obra nem na sua leveza. Chega também a pintar marinhas, nas quais é claro seu interesse pelos reflexos coloridos das ilhas e rochas próximas. Suas composições com poucos traços chegam mesmo a ser vaporosas com riscos leves e colorido apurado.

Adami foi aluno de Norfini de 1913 a 1916, no período em que estudou no Liceu de Artes e Ofícios, em São Paulo. Lá, então, entrou mais uma vez em contato com as características da pintura dos macchiaiolli, antes vista com Giusepe Barchitta.

Levando-se em consideração esses dados levantados sobre seus primeiros professores, deve ser evitado, então, pensar que Adami tenha passado incólume aos ensinamentos desses seus mestres, pois, ao serem examinadas suas pinturas de paisagens entre 1917 e 21 , nota-se a observação naturalista da cor e do entorno, muito distanciado da orientação acadêmica.

$$
\text { Jorge Fischer Elpons (1895 - 1939) }
$$

Di Cavalcanti ao relatar o início de sua aprendizagem com Elpons assim o descreve:

(...) antiacadêmico, um misto de arte caricatural, pós-impressionismo, art-nouveau, expressionismo e estilização, temperados, sobretudo por uma inquieta vontade de explorar as diversas tendências modernas e romper com a tradição dominante. $(. . .)^{46}$

Um pouco exageradamente, Di conseguiu ressaltar duas características principais que distanciariam Jorge Fischer Elpons do universo da arte acadêmica. A primeira diz respeito a sua pincelada pastosa e rebuscada, ao uso de cores vibrantes, muitas vezes confundido com o impressionismo mais ligado, na verdade, a influências proto-expressionistas, pois se preocupava com as questões matéricas da cor.

\footnotetext{
${ }^{46}$ Catálogo: A Pinacoteca do Estado. São Paulo: Banco Safra, 1994, p.25.
} 
A segunda descreve o interesse que o pintor demonstrava pelas novas tendências que surgiam na pintura, como a obra de Vincent Van Gogh, ${ }^{47}$ por exemplo, artista que ele considerava.

Elpons pintou poucas paisagens, preferindo mais a natureza-morta com frutas e rosas, suas prediletas.

Formou-se em Munique, na Alemanha, vindo para o Brasil em 1912 e fundando, em 1914, uma escola de pintura com os artistas Wasth Rodrigues e William Zadig. Esses três artistas inauguraram o curso de desenho noturno com modelo vivo, o primeiro em São Paulo. ${ }^{48}$

Estudaram com Elpons, em seu atelier em São Paulo, por volta de 1917, Di Cavalcanti, Hugo Adami, Tarsila do Amaral e Anita Malfatti, entre outros, os quais encontravam na figuração naturalista do mestre alguns elementos inquietantes da pintura moderna como a pincelada vigorosa, matérica e o uso peculiar da cor.

Da produção de Hugo Adami, anterior ao seu deslocamento para a Europa em 1922, foram encontrados até o presente quatorze originais. A maioria paisagens noturnas, ou de dias nublados, onde predominam tons de cinza e verdes escuros, com exceção de "Morro do Castelo", 1921, (figura 12) e "Retrato de Mário de Andrade", 1922, (figura 13), cujas pinceladas são mais pastosas e o colorido mais vibrante, refletindo os ecos macchiaioli de seus professores.

Em outras obras - como "Paisagem de São Miguel Paulista" ou em "Frango", naturezamorta - as cores usadas pelo artista não denotam nenhum idealismo de viés acadêmico, mas apresenta-se como fruto da observação fiel do real.

\footnotetext{
${ }^{47}$ Ibidem, p. 26.

48 TARASANTCHI, Ruth S. Pintores paisagistas em São Paulo. Tese de doutorado. São Paulo: ECA/USP, 1986, p.237.
} 
São claros em suas pinturas dessa época dois princípios que norteavam também seus mestres: a "sinceridade" e a "acuidade".

O primeiro termo pressupunha que o artista traduzisse em suas obras a realidade que lhe fosse verdadeira.

A acuidade significava colocar-se diante da natureza, supostamente liberto de todos os preconceitos. Deste modo, o artista poderia experimentar o que ela oferecia de instantâneo, para captar-lhe o momento. Esses ideais já são típicos da pintura italiana que se desenvolveu na segunda metade do século XIX, aquela dos macchiaioli, a qual, Barchitta e Norfini tiveram contato. Esses pintores desenvolveram suas linguagens pictóricas particulares, mas nortearamse pelo mesmo apreço ao contato direto com a natureza ou realidade que iriam pintar.

Assim, tendo iniciado seu trabalho neste contexto, fica difícil vincular o Realismo Naturalismo das primeiras pinturas de Adami ao Acadêmico, ou mesmo continuar denominando toda a pintura realista/naturalista da época de academismo, pois há muito se distanciara daqueles valores. 


\section{CAPÍTULO II}

\section{O NOVO REALISMO: O RETORNO À ORDEM E O NOVECENTO ITALIANO}

O rastro de destruição deixado pela Primeira Guerra Mundial em 1918, fez com que a crença no positivismo, no materialismo e no cientificismo fosse abalada na Europa. Os intelectuais europeus passam a ver então, com certa ressalva, os progressos e maravilhas da tecnologia. A realidade torna-se ameaçadora e os artistas começam a questionar a arte de vanguarda, vinculada à celebração do progresso.

Na medida em que os anos se aproximam da Segunda Guerra Mundial, a situação se apresenta mais e mais inquietante, obrigando os artistas a se posicionarem basicamente em duas categorias: modernistas ou realistas. ${ }^{49}$

Os chamados modernistas ficariam ligados às vanguardas, Cubismo e Futurismo, enquanto os realistas, portariam em si, todas as ambigüidades do momento: ficariam entre a retórica da informação e da alienação; entre razão e imaginação; progresso e tradição; matéria e espírito; coletividade e individualidade.

Assim, surgia na Europa um novo Realismo, diversificado, contraditório, que buscava encontrar enfim, o equilíbrio perdido entre Modernidade e natureza. ${ }^{50}$ Devido a tantas ambigüidades nele contidas, surgiriam várias facetas desse Novo Realismo: o Surrealismo, o Novo Realismo social e os movimentos de Retorno à Ordem na França, Alemanha e Itália. ${ }^{51}$

Contudo, todas essas facetas desse novo Realismo vão apresentar algo em comum. Fundamentavam-se na crença de um presente caótico e construíram sua arte como metáfora de uma realidade futura ou ideal e até mesmo passada.

\footnotetext{
${ }^{49}$ PAGÉ, Suzanne. “Les Temps Menaçant, 1929 - 1939”. In Les Annès 30 em Europe. Paris: Flammarion, 1997, p. 10 .

${ }^{50}$ FABRE, Gladys. “La Derniere Utopie: lê réel”. In Les Annès 30 em Europe. Paris: Flammarion, 1997, p.49.

${ }^{51}$ Ibidem.
} 
Nostálgicas ou progressistas, as resoluções artísticas desse Realismo estavam comprometidas com a noção de "projeto". Esta noção era idealista, utópica e atribuía à arte a função de construir uma realidade melhor e mais “democrática”. Este preceito era ainda comum ao período modernista e por isso, aquele novo Realismo, não deve ser confundido com passadismo.

O Retorno à Ordem foi uma tendência realista que propiciou a retomada da pintura figurativa tradicional, filtrada por alguns avanços na pintura do final do século XIX, como a obra de Paul Cézanne. Os artistas ligados a ela eram contra os avanços mais radicais das vanguardas históricas, tidos por eles como exageros niilistas.

Tanto na França quanto na Itália e Alemanha, o Retorno à Ordem caracterizou-se basicamente pela reabilitação de valores culturais nacionais, pela recuperação do gosto pela obra bem acabada tecnicamente (gosto pelo métier), e pelo resgate do gosto pela tradição, principalmente no que diz respeito à antigüidade clássica italiana e ao "Classicismo" de Cézanne. ${ }^{52}$

O retorno a estilos de pintura mais conservadores por parte de Henri Matisse, Maurice de Vlaminck e André Derain, (figuras 14 e 15), anteriormente fauvistas, por exemplo, foi entendido por alguns intelectuais franceses como um retrocesso em relação às conquistas cubistas do entre-guerras; além do mais, muitos artistas cujos trabalhos não haviam recebido destaque antes do conflito, agora eram valorizados, como André De Segonzac, Maurice Utrillo, e Marie Laurencin.

O sucesso que esses pintores adquiriram comercialmente refletia na crítica, sendo Louis Vauxcelles, o crítico que os defendia mais ardentemente.

\footnotetext{
${ }^{52}$ Esse assunto será estudado mais detalhadamente no Capítulo III desta dissertação.
} 
Segundo ele, o trabalho desses artistas incorporava um conjunto de virtudes, tais como o amor e o respeito pela natureza e uma abordagem intuitiva e sensual, baseada em sentimento, honestidade, franqueza e inocência. ${ }^{53}$

A "Natureza-Morta com ovos" de Segonzac, (figura 16), baseia-se na observação: seu motivo rústico, as cores terra, os tons escuros, a superfície e o tratamento pesado eram sinais de uma tradição de naturezas-mortas rurais e realistas que iam de Courbet a Van Gogh.

Essas características encontradas na pintura de Segonzac seriam indicadores daquela direção geral que a arte tomava na época, segundo Vauxcelles. O valor dessas obras naturalistas era estabelecido à medida que eram dispostas em contraste direto com os "excessos" e as "falhas" do Cubismo que, para Vauxcelles, sempre personificou a antítese de tudo que tinha valor em arte; esse Movimento era excessivamente intelectual, frio, calculado, carente de espontaneidade ou sentimento. ${ }^{54}$

Porém, nem todos os pintores dessa época - pertencendo ou não à Escola de Paris ${ }^{55}$ iriam desenvolver trabalhos sob a mesma orientação realista; o que tinham em comum, de certo modo, era essa busca de formas mais convencionais de apresentação e um repúdio ao radicalismo das vanguardas.

O Retorno à Ordem na Alemanha concentra-se em um movimento chamado Nova Objetividade, surgido por volta de 1920, termo mais aceito para caracterizar um conjunto de tendências da arte figurativa alemã. Embora mais aceito, ele não era menos impreciso do que outras expressões também usadas para definir aquela manifestação da arte alemã: "Neo-

\footnotetext{
${ }^{53}$ BACHELOR, David. In FER, Briony et. al. Realismo, Racionalismo, Surrealismo. São Paulo: Cosac \& Naify, 1998, p.10.

54 Ibidem, p. 10.

${ }^{55}$ A Escola de Paris foi um grupo de artistas, vindos de várias localidades da Europa e até mesmo de fora dela, (na primeira metade do século XX), que se reuniam nos cafés de Montparnasse em Paris para discutir questões sobre arte e sociedade. Possuíam diferentes linguagens pictóricas sendo a única característica em comum, a preocupação de serem modernos. Argan. Arte Moderna. São Paulo: Cia das Letras, 1992, p.341.
} 
Naturalismo", "Novo Realismo". 56 Foi também caracterizada por uma retomada do clássico, retomada do Realismo engajado de Courbet, e abarcou da mesma forma, preocupações com o Nacionalismo.

Dentro dessas idéias, situou-se também o Novecento Italiano. O Novecento, termo ideado pelo pintor Anselmo Bucci, configura-se numa tendência pictórica figurativa que nasceu em 1922, numa reunião numa galeria de arte milanesa de Lino Pesaro, por iniciativa da crítica de arte Margherita Sarfatti. Sete pintores constituíam o grupo: Anselmo Bucci, Leonardo Dudreville, Piero Marussig, Emílio Malerba, Ubaldo Oppi, Mario Sironi e Achille Funi.

O grupo surgiu então da convivência destas pessoas, sem propósitos definidos ou algum manifesto. Dudreville deixaria o grupo não muito tempo depois de sua fundação por razões ideológicas. A primeira exposição foi em Milão, em 1923. No ano seguinte os seis pintores acima citados, se apresentaram na Bienal de Veneza, da qual Hugo Adami também participou. ${ }^{57}$

Entre 14 de fevereiro e 31 de março de 1926, com o grupo ampliado para 110 expositores, realizaram a primeira Mostra del Novecento Italiano, em Milão, da qual Adami também tomou parte.

Esse novo título do grupo teve o intuito de alargar a sua significação, dando-lhe um sentido mais nacionalista. Após a Bienal de Veneza, muitos artistas aderiram às exposições, entre eles: Ardengo Soffici, Carlo Carrà, Felice Carena, Felice Casoratti, Filippo De Pisis, Gino Severini, Giorgio De Chirico, Giorgio Morandi, Ottoni Rosai e outros.

Na mostra veneziana de 1924, apesar do movimento não ter tido bases definidas, Sarfatti esboçou alguns elementos que integrariam sua poética, mesmo reconhecendo a visão

\footnotetext{
${ }^{56}$ WOOD, Paul. In FER, Briony et. al. Realismo, Racionalismo, Surrealismo. São Paulo: Cosac \& Naify, 1998, p.286.

${ }^{57}$ Sobre as exposições das quais participou Adami, consultar o Capítulo III desta dissertação.
} 
particular de cada artista. Definiu a pintura de Funi como compacta e sólida, identificando-a com os quatrocentistas de Ferrara; Malerba e Dudreville como objetivos; Sironi, destacando sua síntese formal e qualidade da pintura. ${ }^{58}$

No sentido de esclarecer uma suposta orientação estética no movimento, a pesquisadora italiana Rossana Bossaglia redimensiona as leituras correntes sobre o Novecento, evidenciando apenas as proposições formais que seus integrantes colocavam na cena artística italiana e internacional do período, na tentativa de resgatar o que de estético e artístico existiu na produção daqueles artistas. Assim, Bossaglia irá apontar três características básicas do Novecento:

1) a adoção de um estilo fiel ao reconhecível, um caráter naturalista, mas de viés idealizante;

2) uma expressão não descritiva da realidade, idealizada ou não e

3) a consciência de ser uma superação das vanguardas. ${ }^{59}$

Percebe-se assim, que essas três características estão intimamente ligadas àquelas do retorno a ordem no restante da Europa.

Segundo Tadeu Chiarelli, a autora, apesar da acuidade com que descreveu e avaliou o Novecento, parece limitar sua compreensão da arte produzida por ele apenas à sua vertente mais conhecida - aquela que apresenta uma produção voltada para a recuperação dos valores estéticos da primeira Renascença italiana, (e que teria na obra de Mário Sironi o ponto principal). Bossaglia, continua Chiarelli, parece não reconhecer outras vertentes que também foram importantes para o movimento e que talvez, no caso brasileiro, tiveram maior influência.

Já o estudioso Marco Lorandi caracteriza algumas correntes dentro do Novecento e escolhe três artistas que, segundo ele, orientam a compreensão das mesmas: Achille Funi

\footnotetext{
${ }^{58}$ RIBEIRO, Niura. Rossi Osir. Dissertação de mestrado. São Paulo: ECA/USP, 1995, p.52.

${ }^{59}$ BOSSAGLIA, Rossana.Il Novecento Italiano. Milano: Feltrinelle, 1979, p.71.
} 
(figura 17), Mário Sironi (figura 18) e Arturo Tosi (figura 19). A esses três artistas uniriam-se as instâncias estéticas do Novecento, que eram: o Neo-Classicismo ou Neo-Renascimento de Funi, o Classicismo arcaico-mítico de Sironi, o Neo-Cezannismo anti-impressionista de Tosi. ${ }^{60}$ Dentro dessas três orientações, é possível integrar praticamente todos artistas do grupo: no seguimento neo-renascentista estariam: Achille Funi, Andreotti Bacci, Anselmo Bucci, Felice Carena, Felice Casoratti, Giorgio De Chirico dos anos vinte, Antônio Donghi, Leonardo Dudreville, Piero Marussig, Ubaldo Oppi e outros. No grupo arcaico-mítico, junto a Sironi, estariam Massimo Campigli, Carlo Carrà e Alberto Salietti, Raffaele De Grada e os escultores Arturo Martini e Adolfo Wildt, entre outros. No grupo neo-cezanniano, além de Tosi, poderiam ser alinhados Alberto Caligiani, De Grada, entre outros. ${ }^{61}$ É necessário lembrar que essa divisão proposta por Marco Lorandi, não almejava fechar a produção daqueles artistas em modelos estanques, mas apenas facilitar o estudo do Novecento.

A corrente "arcaico-mítica" buscava uma concepção clássica de arte, onde a idealização da realidade unia-se rigorosamente à captação de um real reconhecível. A idealização ocorrida nesta vertente tenderia ao desejo de criação de uma realidade utópica, atemporal e heróica, vazada, porém, por uma plasticidade giottesca, filtrada pelo saber cezanniano. Essa combinação de elementos clássicos de Giotto à geometrização das figuras de Cézanne, confere à essa vertente um caráter mágico-realista.

A corrente "cezanniana", de acordo com Lorandi - como o próprio nome demonstra foi influenciada pelo pintor francês e surgiu nas novas pinturas italianas de então, mediante a geometrização volumétrica do espaço que, por sua vez, decantava a sensação de qualquer resíduo verista, de qualquer reprodução descritiva. A experiência cezanniana parecia,

\footnotetext{
${ }^{60}$ LORANDI, Marco. "Classicismo trionfante: Sironi, Fattori e derivati". In BOSSAGLIA, Rossana. Il Novecento Italiano. Milano: Feltrinelle, 1979, p.63.

${ }^{61}$ Ibidem, p.64.
} 
portanto, repropor aos olhos dos novecentistas, a mesma ótica do processo abstratizante do mundo antigo, clássico/classicista/neoclássico, ao submeter o natural aparente a uma norma capaz de modificar a visão puramente anedótica da realidade.

A pintura de Cézanne possuía um filtro particular e geometrizado para olhar a natureza e este seu Classicismo muito interessou os paisagistas lombardos, entre eles Tosi:

(...) Herdeiro da tradição tonal lombarda, de Leonarso a Ranzoni e Rosso e, ao mesmo tempo, do Classicismo francês de Poussin a Cézanne, Tosi encontrava-se assim na posição de elo de junção com o Ottocento e de primeiro e mais completo representante do Novecento Italiano, como espaço de confluência e síntese dos dois filões estilísticos históricos. $(\ldots)^{62}$

Mas, além dos influxos cezannianos, os paisagistas italianos do período entre-guerras, impregnaram-se igualmente das soluções dos principais paisagistas da Itália no século XIX, os já citados macchiaioli, tanto na estruturação de suas obras quanto na captação da luminosidade regional.

Se alguns artistas do grupo macchiaiolo vinham sendo recuperados desde antes da Primeira Guerra Mundial - como Giovanni Fattori (figura 11), e Daniele Ranzoni - após o conflito sua recuperação estendeu-se e, para os novecentistas, a produção dos macchiaioli foi considerada sempre a partir das relações formais que poderiam ser feitas entre eles e os pintores do Quattrocento. Tal associação, na verdade, era uma estratégia que visava rebater a supremacia da arte francesa na Itália e criar pontes entre a grande tradição da arte italiana e a produção paisagística do pós-guerra.

Para definir a corrente neo-renascentista, Lorandi, compara o Classicismo de Sironi ao de Achille Funi, (este último, principal intérprete desta corrente.). Afirma que, em Funi, o recurso arqueológico é mais abertamente demonstrado, pois segundo o autor, antes de tudo, a

${ }^{62}$ MOLA, Paola. In BOSSAGLIA, Rossana. Il Novecento Italiano. Milano: Feltrinelli, 1979, p. 64. 
tipologia feminina de Vênus - descendente dos parâmetros Ticiano-Giorgione e giorgionescos - o influencia deliberadamente. Ou seja: a corrente "neo-renascentista", representada por Funi, seria uma tentativa de operar dentro da grande tradição da arte italiana, não se restringindo a fazer reviver a visualidade apenas proposta pelos artistas do Quattrocento mas, igualmente, a visualidade dos artistas dos séculos seguintes, que transformaram e enriqueceram aquela mesma tradição. No contexto do Novecento, diz Chiarelli, a corrente "neo-renascentista" seria a principal responsável pela recolocação da tradição artística do Renascimento italiano, do Maneirismo e do Barroco. ${ }^{63}$

Essa postura dos neo-renascentistas novecentistas, ao ser comparada com as outras duas vertentes, parece muito mais radical, do ponto de vista da recuperação da "italianidade" da arte italiana dos anos vinte e trinta. Outro dado significativo sobre os neorenascentistas, é o fato de que seria principalmente por meio de suas obras que o Novecento revitalizaria a produção de pinturas de gênero como retratos e naturezas-mortas. ${ }^{64}$

O pesquisador Kenneth Silver atenta para o perigo de se confundir intencionalmente ou não, o nacionalismo existente nos movimentos de Retorno à Ordem na Europa com um engajamento político. Na Itália, por exemplo, nem todos os artistas do Novecento - para não dizer a maioria - eram a favor de Mussolini, ou desenvolveram pinturas orientadas por seus ideais de poder.

O crítico norte-americano David Bachelor afirma que essas tendências de justificar a arte pela política, geralmente lidam com amplas generalizações e tratam um extenso conjunto de obras individuais como se fossem todas idênticas e, além disso, fazem julgamentos antecipados à observação das evidências da obra. O autor ainda alerta sobre o perigo de

\footnotetext{
${ }^{63}$ CHIARELLI, Tadeu, Arte Internacional Brasileira. São Paulo: Lemos, 1999, p.70

${ }^{64}$ Ibidem, p.71.
} 
reduzir a questão sobre estética e política a uma fórmula, por meio da qual se possa entender que a arte, em razão de certas características gerais, deva apresentar algum viés político.

A pesquisadora Rossana Bossaglia, antes de caracterizar propriamente o Novecento, preocupase em retirar de seu entendimento alguns preconceitos que o envolveram, como o seu suspeito vínculo com o Fascismo. A historiadora italiana faz com o Novecento aquilo que Bachelor e Wood tentaram fazer com a Nova Objetividade Alemã: separar os fatores estéticos que a estruturavam das questões políticas.

Para Bossaglia, o Novecento surge num momento histórico no qual o Fascismo na Itália não possuia condições para produzir uma política para a arte. Por outro lado, sustenta que o Novecento sofreria oposição ao longo de seu percurso, dentro do próprio regime. Afirma em seguida que aquele não foi um movimento provinciano, na medida em que se inscrevia, como visto há pouco, no contexto mais geral do chamado Retorno à Ordem.

Chiarelli afirma que a intenção de Bossaglia em retirar logo de início a possibilidade de pensar o Novecento apenas como arte oficial do Fascismo, pode ter se originado de pelo menos três circunstâncias bastante peculiares, que reforçariam aquele preconceito: as relações de amizade entre a idealizadora do grupo, a crítica Margherita Sarfatti, e Benito Mussolini; o fato de Sarfatti ter escrito no jornal Popolo di Itália, jornal fascista; Mussolini ter marcado presença em duas exposições novecentistas, a de 1923 e a de $1926 .{ }^{65}$ Segundo a autora, esses dados não justificariam o engajamento de todos os membros do Novecento ao Fascismo.

Por outro lado, a única característica que poderia aproximar o Novecento do Fascismo seria a questão do nacionalismo, mas não se deve esquecer que, antes mesmo de ser iniciado o Fascismo, Carrà, desde 1916, revia Giotto, e que o retorno às tradições nacionais não foi um fenômeno isolado na Itália, ou seja, estritamente fascista. Existiu mais a vontade do Fascismo

\footnotetext{
${ }^{65}$ CHIARELLI, Tadeu. Arte Internacional Brasileira. São Paulo: Lemos, 1999, p.62.
} 
em se impor como arte do que propriamente uma iconografia novecentista comprometida com aquele movimento político. ${ }^{66}$ Isto é, o Fascismo almejava utilizar-se da arte novecentista para fins propagandistas e aproveitou a questão nacionalista de retorno à história da arte italiana própria do Novecento - para fundir-se com ele.

Esse regime nunca elaborou uma cartilha, um programa que o Novecento devesse seguir, até mesmo porque não foi um movimento organizado e sim, agrupamentos de artistas de diversas tendências visando a produção de exposições de trabalhos de arte. ${ }^{67}$

O objetivo deste estudo foi estabelecer breves considerações sobre o Retorno à Ordem em seus aspectos gerais e sobre o Novecento em particular. As várias facetas que esse novo Realismo teve na Europa não foram por inteiro tratadas aqui, porque o mais interessante para este estudo foi o período de 1922 a 1927, quando Adami entra em contato pela primeira vez com aquelas tendências e amadurece sua pintura.

Como foi visto no Capítulo I, é possível, de início, aproximar as primeiras pinturas de Adami à vertente realista/naturalista e suas pinturas realizadas entre 1923 a 1945, ao novo Realismo Europeu, caracterizado pelo Retorno à Ordem do entre guerras.

Pode-se até mesmo afirmar que, no decorrer do desenvolvimento das correntes de Retorno à Ordem na Europa, apareceu um novo tipo de Realismo, o "Realismo Clássico"; aquele que tentava recuperar os supostos valores eternos da arte, baseados na síntese formal e dos assuntos escolhidos para as obras.

Esses valores “eternos” estariam ligados à preservação do métier e dos valores essencialmente plásticos da pintura, fazendo com que essa última assumisse uma abordagem

\footnotetext{
${ }^{66}$ RIBEIRO, Niura. Rossi Osir. Dissertação de mestrado. São Paulo: ECA/USP, 1995, p.54.

${ }^{67}$ BOSSAGLIA, Rossana, (org.). Il Novecento Italiano. Milano: Feltrinell, 1979, p.19.
} 
historicista da própria pintura, já que iria buscar, no caso italiano do Novecento, os valores formais nos pintores da Renascença, como Masaccio, Giotto ou Piero Della Francesca Hugo Adami se deixaria impregnar por esses valores plásticos do Realismo Clássico principalmente dentro das correntes cezanniana (paisagens) e da pintura de De Chirico.

Nos capítulos seguintes serão estudadas detalhadamente como as questões do Novecento se manifestaram na pintura de Adami. 


\section{CAPÍTULO III}

\section{O APRENDIZADO NA ITÁLIA E PARIS}

Quando Hugo Adami chegou na Itália, na primavera de 1922, encontrou ainda um país abalado pelo desfecho da Primeira Guerra Mundial. Embora a Itália tivesse sido membro da vitoriosa coligação dos aliados, seu saldo de guerra não era nada animador: uma média de 650 mil homens haviam sido mortos ou feridos em campo; dez por cento dos trabalhadores industriais estavam desempregados; os preços subiam rapidamente e os salários baixavam. Além disso, a Itália se sentia traída, já que os países aliados (França, Alemanha e Inglaterra), não cumpriram o Tratado de Londres, que lhe asseguraria a posse das terras eslavas da Dalmácia. ${ }^{68}$ Essa situação contribuiu para que nascesse ali, uma política de caráter ditatorial, no caso, o Fascismo.

Após a Guerra, Benito Mussolini, líder fascista, apresentou um programa radical e nacionalista de mudança social, que favorecia os trabalhadores de indústria na Itália e instigava a população a ir contra os países capitalistas, que teriam privado sua terra natal do território eslavo. ${ }^{69}$ A Itália precisava de equilíbrio e ordem, o que acreditou encontrar na política de Mussolini.

Paralelamente à ascensão do Fascismo, surgia naquele mesmo ano em Milão, um grupo de artistas e críticos denominado Novecento Italiano, aqui já comentado, propondo no campo da estética a mesma segurança que o partido fascista propunha para a política da Itália.

O Novecento - assim como certos textos críticos presentes nas revistas que o

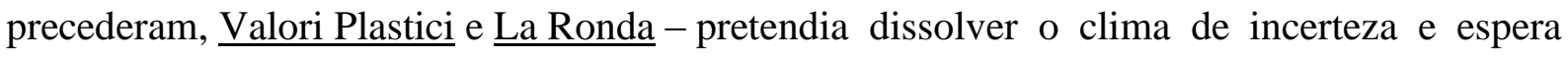

\footnotetext{
${ }^{68}$ Para aprofundar esse assunto, consultar o texto "The rise of Fascism in an Industrial City" in ABSE, Tobias. Rethinking Fascism. NY: The NY University Press, p.52-58.

${ }^{69}$ BRINTON, Crane, CHRISTOFER, John e WOLF, Robert. A History of civilization, V. II. New Jersey: Prentice Hall Inc.s/d, p.440.
} 
existente no país com a força de um projeto artístico que se baseasse no equilíbrio, na ordem e na moralidade. Um projeto que considerava a arte como tradição e continuidade étnica e histórica italiana, sem os exageros vanguardistas, experimentais e estrangeiros. ${ }^{70}$

E nesse panorama desembarcava Adami, instalando-se em Florença.

Uns três ou quatro dias após ter ali chegado, o artista contou ter entrado em um café chamado Giube Rosse, onde se reuniam vários intelectuais da época. Como não usava chapéu na ocasião - Adami havia notado que grande parte dos moços italianos não usavam chapéu, e assim, saiu sem o seu. O que não sabia era que "o não usar chapéu” em Florença, naquela época, era um código para os fascistas ou simpatizantes se identificarem. Assim, logo foi dado por fascista e incitado a uma briga no local pelo poeta, e seu futuro amigo, Berto Ricci:

(...) Estávamos na época do Mussolini, aquelas coisas, aquelas brigas, sabe como é...De repente, vem ali uma escaramuça, todo mundo começa a tomar partido, uns para a direita, outros para o lado esquerdo. E então, esse rapaz pensou que eu fosse fascista, porque os fascistas não usavam chapéu e nisso me convidou - você é um fascista, fica aí sentado? - ele estava com raiva, e então, entrei na briga. (... $)^{71}$

Assim Adami contou ter conhecido naquela oportunidade, não apenas o poeta Berto Ricci, mas também os pintores Ardengo Soffici e Otoni Rosai, que o convidaram para acompanha-los à abertura da exposição Primaveril de Florença, onde De Chirico expunha em uma sala especial.

\footnotetext{
${ }^{70}$ FOSSATI, Paolo. Valori Plastici: 1918 -1922. Torino: Einaudi, 1981, p.72.

${ }^{71}$. Entrevista concedida por Hugo Adami ao artista Antônio Hélio Cabral no Museu Lasar Segall, São Paulo, março de 1976, fita c, p.13.
} 


\section{III.a. - Artistas significativos para a formação de Adami}

\section{Giorgio De Chirico}

Adami se interessou muito pela pintura de De Chirico, sendo aquelas do período metafísico as que mais o haviam impressionado dentre todas presentes na exposição. Chegou a retornar à mostra por mais três ou quatro vezes até que De Chirico o abordasse. Ao perguntar a Adami se gostava de sua pintura, o artista brasileiro lhe respondeu que não sabia se gostava, mas que aquela pintura o instigava: "aquelas figuras de objetos, aquelas colunas gregas, os compassos, uma série de coisas, figuras geométricas, cópia de espaços infinitos, uma pintura mágica" ${ }^{72}$

Embora De Chirico já desenvolvesse na época uma pintura afastada de sua fase totalmente metafísica, indo - segundo Rossana Bossaglia - para um "Classicismo Simbólico", 73 naquela exposição Adami parece ter visto seus primeiros quadros metafísicos, devido a descrição que fez dos trabalhos que examinou: compassos, objetos e figuras geométricas, (típicos da pintura da primeira fase metafísica de De Chirico). ${ }^{74}$

\footnotetext{
72 Ibidem, fita a, p.32.

${ }^{73}$ BOSSAGLIA, Rossana. Il Novecento italiano. Milano: Feltrinelli, 1979, p.71.

74 A metafísica foi uma pintura desenvolvida por De Chirico a partir de 1911 em Ferrara tendo por objetivo apontar uma realidade absurda, sem vínculos com a natureza ou a história Vinha como oposição ao tumultuado precursionismo futurista, caracterizada por uma classicidade absoluta, exterior ao tempo. Não havia na metafísica nenhuma sombra de nacionalismo, mas apenas o desejo de mostrar uma dimensão interior inalcansável pelo alarido das fábricas, dos negócios e das guerras. Segundo as idéias metafísicas de De Chirico, a arte em suma, não poderia manter qualquer relação com o mundo presente, não poderia combater ou sequer defender uma ideologia, mas deveria ser ela mesma. A arte metafísica não tinha finalidades cognitivas nem práticas; sua presença era ambígua, inquietante, contraditória. Colocava formas sem substância vital num espaço vazio e inabitável, num tempo não eterno, mas imóvel. Muito antes dos dadaístas, De Chirico sentiu e denunciou a incongruência da arte na civilização moderna, ou seja, inútil procurar remédios impossíveis, sua razão de ser era o ser em contradição. Assim, descrente no presente, De Chirico iria procurar a arte nos antigos clássicos italianos, pois apenas na história da arte poderia haver arte. Mais tarde, Carrà iria incluir a história em sua metafísica, por meio da citação de suas memórias em seus trabalhos e de um espaço presente, realista, desenvolvendo sua pintura para uma abordagem histórica, vinculada de certa forma com o presente, o que caracterizaria a pintura do Novecento (pois tais pintores "retratavam" seu entorno real, paisagens pessoas e naturezas-mortas, mesmo baseando-se na estética dos mestres clássicos). ARGAN, Giulio C. Arte Moderna. São Paulo: Cia das Letras, 1992, p.372.
} 
Os dois tornaram-se amigos e passaram a conversar sobre pintura e até mesmo a pintarem lado a lado, quando estiveram em Paris, por volta de 1926/27. Naquele período, em contato com de Chirico e demais pintores, (como Rosai, Morandi, Soffici, Casorati), Adami aprendeu a valorizar a arte clássica italiana, o métier e a observar a natureza, sem, contudo, pretender imitala, ou subjugar-se a ela.

Em um de seus textos, publicado na revista Valori Plastici. ${ }^{75}$ De Chirico criticava avidamente a produção de vanguarda existente na Itália e na Europa da época, chamando-a de anárquica e indisciplinada. Afirmava não haver ninguém para corrigir, julgar, aconselhar, ensinar ou ditar uma lei, estabelecer um princípio. Dizia que a obra medíocre não corria mais os riscos que corria antigamente, já que, tendo sido apagada nos pintores de então a verdadeira paixão, o mesmo aconteceria com o público, que não saberia mais como exigir e apreciar. Insistia que os artistas de sua época não buscavam entusiasmo na arte, mas na agitação coletivista, ou seja, um mero desejo de seguir a tendência em voga, por "divertimento". Segundo ele, em oposição, os artistas antigos, ou clássicos, do período quatrocentesco, preocupavam-se com o real valor pictórico, com o domínio do métier ou técnicas da pintura. Aquelas excelentes construções plásticas emergiam na massa de suas formas livres da sensualidade mundana do modismo. ${ }^{76}$

De Chirico defendia o retorno ao métier, ao aprendizado nos museus: Nossos artistas deveriam estar atentos ao aperfeiçoamento dos meios - telas, cores, pinceladas, óleos, vernizes - deveriam ser escolhidos entre aqueles de melhor qualidade. ${ }^{77}$

Dos anos vinte até os anos trinta, De Chirico orientou-se pela valorização da produção clássica italiana e retomou temas mitológicos passando a rever sobretudo a tradição barroca e

\footnotetext{
${ }^{75}$ Valori Plastici foi uma revista editada por Mário broglio na Itália, entre 1918 e 1922, precursora do Novecento Italiano.

76 DE CHIRICO, Giorgio.DELL'ARCO, Maurizio F. (org.). Il meccanismo del Pensiero: crítica, polemica, autobiografia, 1911 - 1943. Torino: Einaudi, 1985, p.97.

${ }^{77}$ Ibidem, p.127.
} 
a do período Seicento, que antes desprezava. Afastou-se um pouco da metafísica, produzindo uma pintura de influência clássica, guiada pelos mitos greco-romanos, ${ }^{78}$ mas não abandonando totalmente a simbologia daquela sua pintura anterior.

Tanto De Chirico quanto os outros pintores da época, não prezavam somente os pintores clássicos do Quatrocento, Trecento ou Seicento italianos, mas também pintores franceses que consideravam mestres, como Nicolas Poussin, Jean Baptiste Simeon Chardin e Paul Cézanne. Em entrevista, Adami mencionou um episódio, ocorrido em 1926, quando estava em Positano. Lá, encontrou um pintor norueguês chamado Roft, que lhe ensinou uma mistura para preparação de telas, criada por Renoir.

Dias depois, em Paris, Adami reencontrou-se com De Chirico e lhe passou a tal fórmula: "Era feita com carbonato de cálcio, óleo de oliva, gostosa até, gesso, gelatina e cola... De Chirico sempre teve muita curiosidade quanto à inovação, preparação de telas; sabe, você inventava uma fórmula para a tela e ele fazia a experiência". ${ }^{79}$

Assim, prepararam as telas e depois de uns quinze dias, De Chirico procurou Adami para lhe mostrar os quadros prontos. Segundo o pintor brasileiro, eram três ou quatro naturezasmortas onde De Chirico havia voltado completamente ao figurativo e ao Naturalismo, com um colorido luminoso lembrando propositalmente o colorido de Renoir. ${ }^{80}$

Esse episódio serve para ilustrar a importância e o valor que os artistas italianos daquela época davam para o domínio de técnicas pictóricas, lembrando também que preparavam suas tintas. Adami relatou:

(...) Numa fase, também cheguei a preparar minhas tintas. Achava que era interessante ficar um conhecedor da maneira de produzir sua própria tinta, até aquele ponto que condiz com a personalidade... que faz parte da gente, que não perece, é uma característica.... pode-se descobrir até tons novos, como os pintores da

\footnotetext{
${ }^{78}$ CARLUCCIO, Luigi. La faccia nascosta della luna: scritti scelti. Itália: Umberto Alemandi \& Cia, 1974, p.118. ${ }^{79}$ Entrevista concedida por Hugo Adami ao artista Antônio Hélio Cabral no Museu Lasar Segall, São Paulo, março de 1976, fita b, p.5.

${ }^{80}$ Ibidem, p.7.
} 
Renascença que tinham cores que outros não tinham. Seus tons eram pessoais, ficavam quase que fazendo parte da palheta do artista e revelavam sua preferência por certos cobaltos, lápis lazuli, que usavam muito. (...) ${ }^{81}$

Mas, como dizia De Chirico, tornar ao métier não seria coisa fácil e demandaria tempo e fadiga. ${ }^{82}$ Mas Adami não se intimidou com o desafio que a pintura italiana exigia na época e procurou sempre observar, experimentar e aprender. De seu companheiro De Chirico, herdou a atenção ao apuro técnico, o apreço aos mestres clássicos italianos e ao que chamou de "magia metafísica”, vista claramente em algumas de suas naturezas-mortas.

\section{Felice Carena}

Logo que chegou a Florença, em 1922, Adami freqüentou a Academia de Belas Artes, tendo como professor Felice Carena. Porém, depois de dois meses e meio, desistiu das aulas. De acordo com Adami, Carena era um ótimo pintor, porém um orientador difícil, pois não aceitava o que não fosse de seu gosto:

(...) Carena não gostava de certos pintores que não seguiam sua orientação, que tinham uma pintura completamente afastada das convicções dele e da imagem de sua pintura. Era de um narcisismo danado. Tanto que um de seus alunos confessou que seu maior sofrimento era não agradar o Carena. Mas não conseguia. A pintura dele era uma pintura que o Carena detestava e acabou indo embora para Roma. (... $)^{83}$

Tempos depois, contou Adami, o tal aluno teve sua obra reconhecida em Roma e Carena admitiu então, que ele não era um mau pintor. Ao contrário desse jovem, a pintura de Adami não desgostava o professor, pelo contrário, Carena apreciava seu figurativismo. Contudo, o

\footnotetext{
${ }^{81}$ Ibidem, fita d, p.22.

${ }^{82}$ DE CHIRICO, Giorgio. DELL'ARCO, Maurizio F. (org.). Il meccanismo del pensiero: critica, polemica e autobiografia, 1919 al 1943 . Torino: Einaudi, 1985, p.95.

${ }^{83}$ Entrevista concedida por Hugo Adami ao artista Antônio Hélio Cabral no Museu Lasar Segall, São Paulo, março de 1976, fita b, p.40.
} 
então jovem pintor brasileiro abandonou o mestre por temer o que chamava de "mimetismo" ou "imitação". Ao ver seu modo radical de orientar, temeu acabar por copiá-lo:

(...) eu não queria ceder em relação a nenhum pintor vivo, contemporâneo meu...Eu achava que os mestres antigos eram muito mais fabulosos que os pintores vivos, em torno de mim...Eu ficava assim preocupado em não ter influência dos pintores (...). ${ }^{84}$

Os ideais de simplicidade e honestidade adotados por Adami de seus professores italianos no Brasil (vindos dos macchiaioli), pareciam ainda reverberar, devido à ojeriza à idéia de copiar ou deixar que sua própria linguagem se anulasse em prol daquela de um outro pintor.

Queria desenvolver uma pintura sua, por meio da observação direta da natureza. Todavia Adami era consciente do importante papel que o diálogo com as obras dos outros pintores exercia para a formação de um artista, mas contanto que não visse sua pintura transformar-se ou confundir-se com a obra de outro pintor. ${ }^{85}$

Assim, o artista brasileiro abandona Carena e a Academia de Belas Artes de Florença para começar suas andanças pela Itália.

Porém, antes de iniciar suas viagens, ele se envolve rapidamente com o que chamou de "a pintura futurista".

Não há documentação alguma sobre essas suas experiências, a não ser em seus depoimentos, onde é claro o desinteresse de Adami por essa pintura. Ele contou que deixou de lado toda aquela "experiência futurista" em 1924, ao se deparar com os afrescos de Masaccio na capela Brancacci da igreja do Carmo, na capital toscana.

Não deve ser esquecido, contudo, que Adami naquele ano já havia entrado em contato com as idéias de De Chirico quanto a valorização dos antigos pintores italianos, e assim,

\footnotetext{
${ }^{84}$ Ibidem, fita a, p.37.

${ }^{85}$ Ibidem, fita a, p.56.
} 
desistiu precocemente do Futurismo para dedicar-se à observação das obras de Masaccio, devido a orientação dechiriquiana. ${ }^{86}$

Vindo de uma formação realista/naturalista no Brasil, influenciada pelos pintores italianos do final do século XIX, os elementos da corrente de Retorno à Ordem na Itália iriam encontrar terreno fértil nas idéias de Adami sobre a pintura; e por isso, como afirmou Mário Barata, Adami, ao ver os trabalhos de Masaccio, “já estava preparado para compreender o que poderia utilizar da estupenda forma plástica e da cor simplificada do grande quatrocentista italiano". ${ }^{87}$ Isso sem se esquecer o fato de Adami já ter assimilado, com De Chirico, algumas idéias sobre o Retorno à Ordem, como a volta aos clássicos e a valorização do métier.

\section{Masaccio e Giotto}

Adami descreve os afrescos de Masaccio como documentação fabulosa do drama religioso da época, possuindo um rigor que, até então, não havia encontrado em nenhuma outra pintura. ${ }^{88}$

Masaccio derivava claramente de Giotto, com um Naturalismo mais acentuado ao elaborar a figura humana e ao descrever seu espaço em perspectiva, tendo assimilado seu gosto pela impressão tridimensional através da perspectiva de Bruneleschi.

Na capela Brancaccio, Masaccio teve a oportunidade de trabalhar em grande escala. Seu Realismo era completamente maduro, mas se mantinha austero e controlado. Nas pinturas do artista que Adami pôde observar, a figura humana era representada de maneira sólida, mas não rígida; apresentavam movimento, mas continha certo equilíbrio em si mesmas, o que dava

\footnotetext{
${ }^{86}$ Além disso, como bem observou o Professor Lorenzo Mammi, teria sido impossível Adami só ter visto as obras de Masaccio depois de 1924, já que chegou em Florença em 1922.

${ }^{87}$ BARATA, Mário. Dados Histórico-críticos sobre Hugo Adami. São Paulo: Instituto Cultural Itaú, centro de Informática e Cultura, 1991, p.4.

${ }^{88}$ Entrevista concedida por Hugo Adami ao artista Antônio Hélio Cabral no Museu Lasar Segall, São Paulo, março de 1976, fita a, p.31.
} 
a impressão de peso, volume, solidez. Toda informação trivial e mundana havia sido descartada; seu Classicismo preocupava-se com a figura humana em sua unidade e as faces eram moldadas com o feitio maciço das esculturas arcaicas. Muitas dessas características como volume, sobriedade e solidez, serão vistas na produção pictórica de Adami entre 1937 e 45, quando para de produzir.

Os pintores novecentistas não prezavam Masaccio e Giotto simplesmente por ambos terem apurado o Naturalismo e saído da rigidez formal absoluta da arte bizantina e medieval. Eles se sentiam atraídos por suas obras, tanto pelo fato de serem italianos (nacionalismo novecentista), quanto pelo seu Realismo envolto em uma atmosfera mística. Para os pintores do Novecento, a realidade não lhes interessava pelo simples fato de ser realidade, nem o fantasioso pelo simples fato de o ser; queriam a tensão entre o real e o ideal, por eles definida como o algo mágico, possível de ser encontrado no cotidiano dos homens e das coisas. ${ }^{89}$

Carlo Carrà se interessou por Giotto por achar que seu Naturalismo ainda não havia sido corrompido pelo Romantismo ou Barroco, conservando uma austeridade religiosa:

(...) dizer que Giotto não era místico, mas somente naturalista é dizer menos que nada, sua realidade plástica é diferente de muitos realistas/naturalistas, assim, é na sua generosidade de beleza que se encontra a admiração que agrada o espírito. (...) $)^{90}$

Não deve ser esquecido de acordo com Lorandi, que Carrà caracterizou uma das correntes do Novecento - a "arcaico-mítica" - retornando aos clássicos por meio dos temas míticos, e adotando para sua pintura uma forma rígida, arcaizante.

\footnotetext{
${ }^{89}$ BONTEMPELLI, Massimo in BAROCCHI, Paola. Storia moderna dell'arte in Italia. Torino: Einaudi, 1990, p.32.

${ }^{90}$ CARRÀ, Carlo. CARRÀ, Massimo (org.). Tutti gli scritti. Milano: Feltrinelli, 1978, p.69.
} 
Mas Adami não segue a linha de Carrà, adotando temas nitidamente míticos ou enrijecendo a forma das figuras em sua pintura. Parece ter compreendido esse lado espiritual, de uma outra maneira.

Segundo o crítico de arte Mário Tinti, ${ }^{91}$ o espiritual dos trabalhos do Quatrocento estava no fato de idealizarem a forma. Assim, Adami encontrará o espiritual naquelas pinturas por meio do volume e da cor, elementos que caracterizam sua produção pictórica da época.

Após examinar os afrescos de Masaccio, Adami vai até Assis para conhecer a pintura de Giotto. Impressionou-se com seu Realismo inovador na Renascença primitiva, com sua síntese formal e suas cores. ${ }^{92}$ Foi para Assis com a intenção de ficar duas semanas e acabou ficando ali por dois meses, pintando e estudando Giotto. Fez amizade com os frades franciscanos e, por meio deles, tomou conhecimento da história de São Francisco e de alguns de seus poemas inéditos, o que deve tê-lo ajudado a apreciar as passagens da vida do santo, realizadas pelo mestre renascentista.

Adami chegou a pintar paisagens em Assis e redondezas e, ao se pronunciar sobre elas, usou expressões como "arquitetura medieval" e "campos geométricos", para descrever as paisagens que via. ${ }^{93}$ Sua visão de Assis, na verdade, pode ser em parte derivada da maneira como De Chirico considerava os trabalhos de Giotto. De Chirico valorizava a arquitetura sóbria do mestre e a modelagem geométrica das figuras, fechadas em si mesmas. ${ }^{94}$ Depois de estar em Assis, Adami passou pela costa Amalfitana, visitando Sorrento e Positano, onde pintou predominantemente paisagens. Seguiu então para San Giminiano, continuando a dar grande atenção às paisagens.

\footnotetext{
91 TINTI, Mario “Il Convegno d'arte”. Cronache D’Arte, sem mais referências.

92 Entrevista concedida por Hugo Adami ao artista Antônio Hélio Cabral no Museu Lasar Segall, São Paulo, março de 1976, fita e, p.1.

${ }^{93}$ Ibidem, fita a, p.3.

${ }^{94}$ CALVESI, Maurizio. La metafisica schiarita. Milano: Feltrinelli, 1982, p.61.
} 
Dos mestres renascentistas, o artista brasileiro parece ter assimilado o tratamento volumétrico da figura e o tonalismo na cor. Mas ao observar suas paisagens desse período, não é possível descartar a atenção que certamente deu a outro importante artista, Cézanne, sobretudo no que diz respeito ao estudo da natureza e à busca do desenvolvimento de uma linguagem pessoal.

\section{Cézanne}

Paul Cézanne é considerado por muitos críticos (Erle Loran, Roger Fry e Clement Greenberg, entre outros), como um pintor clássico. Não por seu trabalho possuir qualquer semelhança com aqueles dos clássicos antigos, mas pelo modo como conduziu e pensou sua arte.

Em 1904, o crítico francês Emile Bernard dizia que Classicismo significava qualquer estilo de arte governado por princípios fundamentais de expressão comunicativa. ${ }^{95}$ Ou seja, o artista deveria desenvolver um modo particular seu, sua própria linguagem, que apresentasse seu pensamento plástico.

Roger Fry diria que um trabalho de arte é clássico quando depende de sua organização formal para evocar emoção. ${ }^{96}$ Essa questão ficará mais clara ao se examinar a poética de Cézanne. O artista acreditava que a natureza caía diante de nossos olhos e nos dava a pintura; que deveríamos dar a imagem do que víssemos, esquecendo tudo que existiu antes de nós em arte. Cézanne falava em pintar a natureza de acordo com sua personalidade e não de acordo com um modelo. Queria trazer para a arte o frescor da natureza em uma nova linguagem. ${ }^{97} \mathrm{Ou}$ seja, queria olhar para a natureza por meio de sua própria linguagem ou concepção, além de

\footnotetext{
${ }^{95}$ SHIFF, Richard. Cézanne and the end of Impressionism: a study of the theory, technique and critical evaluation of modern art. Chicago: Chicago University Press, 1984, p.125.

${ }^{96}$ FRY, Roger. In SHIFF, Richard. Ibidem, p.142.

${ }^{97}$ FRY, Roger. Ibidem, p. 183.
} 
considerar a pintura não como uma mera representação do real, mas como um novo espaço onde as suas questões pictóricas se resolveriam.

Depois de tanto estudar e pesquisar, Cézanne amadureceu sua poética, encontrada na composição de seus quadros pelo contraste modular de tons de cor. De fato, a plasticidade e luminosidade de suas pinceladas coloridas, animadas por seu temperamento, (como se fossem contrastes dramáticos), não foram usadas para adequar os efeitos naturais à pintura ou para analisar uma cena. Elas foram usadas para formar um "lugar de realização". Isto é: em vez de ser uma cena da natureza, a pintura era um local abstrato a ser animado pela projeção do temperamento artístico de Cézanne; e as pinceladas coloridas, fragmentadas, eram os sinais desse temperamento ali realizado. ${ }^{98}$

Com essas pinceladas, Cézanne também conseguiu um efeito de volume sólido. Ele modulava a cor do quente ao frio, em justaposições; e, por meio dessas modulações estilhaçadas, conseguia uma noção de perspectiva e volume na sua pintura. Sua perspectiva não era mais a euclidiana, renascentista por excelência, porque suas áreas de cor ou espaço mantinham-se no mesmo plano, dando a noção de profundidade apenas pelos contrastes de cor. Por outro lado, as verticais e horizontais não podem ser esquecidas nesse processo de construção espacial de Cézanne. Sua perspectiva começa a distanciar-se da euclidiana devido ao fato de construir seu espaço mediante contrastes de planos verticais e horizontais e pinceladas fragmentadas de cor. ${ }^{99}$

Mesmo dando tanta ênfase à cor na construção de seus quadros, Cézanne não negava a importância do desenho. A definição dos contornos desenvolveu-se simultaneamente com o preenchimento das áreas de cor. Quando a cor atropelava as bordas de um plano, fazendo o desenho indistingüível, uma nova linha era superposta. À medida que a cor se tornava

\footnotetext{
${ }^{98}$ MEDINA, Joyce. Cézanne and modernism: the poetics of painting. New York: State University of N.Y. Press, s/d, p.91.

${ }^{99}$ LORAN, Erle. Cézanne’s composition. Califórnia: University of California Press, 1963, p.10 - 13.
} 
mais intrusa, ou mais rica e translúcida, os contornos precisariam ser alterados de camada em camada. É um único método de desenvolver linha e cor simultaneamente. ${ }^{100}$

Em antigos procedimentos na história da pintura, desenho e chiaroscuro eram os responsáveis pela forma e composição em um quadro, deixando a cor em segundo plano.

O que chamaria a atenção dos pintores novecentistas em Cézanne, era a modulação da cor e seu efeito volumétrico, assim como sua harmonização entre linha e cor e seu modo de olhar a natureza como mundo que envolve o artista e o motiva a criar uma nova realidade na tela. Lorandi define bem a influências das idéias de Cézanne sobre os pintores do Novecento:

(...) no geral, a ligação de Cézanne surge interpretada nas inovações mais vitoriosas de redução do particular e do anedótico, unidade e síntese de visão mediante a geometrização volumétrica do espaço que decanta a sensação de qualquer resíduo verista, de qualquer reprodução descritiva. A experiência cezannianaana parecia, portanto, repropor aos olhos dos novecentistas, a mesma ótica do processo abstratizante do mundo antigo, clássicoclassicista-neoclássico, ao submeter o natural aparente a uma norma capaz de quintessenciar o valor ideal ou simbólico da imagem. (... $)^{101}$

Neste trecho, fica claro a relação que os novecentistas estabeleceram com a pintura de Cézanne. Queriam fazer uma pintura realista, mas não fiel ao Naturalismo. Viam nas inovações formais de Cézanne uma possibilidade de entrarem em contato com a natureza e, a partir dela, desenvolverem suas linguagens plásticas.

Embora afirmasse ter ligado sua obra aos primitivos, como Masaccio e Giotto, Adami não nega ter sempre estudado e apreciado Cézanne. Afirmava descobrir novos aspectos no artista francês, a cada vez que olhava sua pintura. (Chegou a visitar uma exposição do mestre de Aix, em 1926, quando morava em Paris). ${ }^{102}$

\footnotetext{
100 Ibidem, p. 15.

${ }^{101}$ LORANDI, Marco. In BOSSAGLIA, Rossana. Il Novecento Italiano. Milano: Feltrinelli, 1979, p.71.

102 Entrevista concedida por Hugo Adami ao artista Antônio Hélio Cabral no Museu Lasar Segall, São Paulo, março de 1976, fita f, p.16.
} 
Adami parecia dividir com seus colegas novecentistas e Cézanne, a maneira de ver a natureza. $\mathrm{O}$ artista confessou nunca ter desejado afastar-se do figurativo, pois queria uma pintura "reconhecível" por todos. Dizia que a natureza estava pronta, bastava olhar para ela e pinta-la; mas sem imita-la ou a outro pintor; cada artista deveria descobrir sua própria pintura, sua própria personalidade, ou linguagem. ${ }^{103}$

Adami viu a natureza, assim como Cézanne: um campo envolvente no qual o artista existia; uma fonte perene de inspiração pictórica, filtrada pela consciência do artista.

Embora construísse suas paisagens toscanas por meio de formas cúbicas (pertencentes à consciência humana), Adami não rompeu com o contorno volumétrico herdado dos clássicos, definindo sua composição não por contrastes - como na pintura de Cézanne, mas pelo tonalismo harmonizante de suas cores e sombras.

\section{Morandi}

As idéias de Cézanne ecoaram também em Morandi. Ao falar sobre o último, Adami parece ter sido cativado por sua linguagem pictórica e pela postura perante a natureza e a criação de trabalhos de arte, que ambos haviam assimilado do mestre francês:

(...) era um pintor fabuloso, de uma honestidade. Esse tem uma sinceridade, sabe como é? Continuidade; desenvolveu a personalidade; há um crescendo dentro da própria formação dele... Ele não traía o próprio físico, digamos. (...). ${ }^{104}$

O que Adami chama de "honesto e sincero" na pintura de Morandi, é o fato de basearse na observação da natureza, do entorno, e daí desenvolver sua própria linguagem plástica, ou seja, sua própria personalidade, como havia ensinado Cézanne.

\footnotetext{
103 Ibidem, fita d, p.9.

${ }^{104}$ Ibidem, fita a, p.44.
} 
Para Morandi, o espaço era a realidade colocada e experimentada pela consciência ${ }^{105}$ ou seja, observava a natureza para desenvolver sua própria poética. Ele realizou figurativamente o espaço, isto é, em sua pintura, massas e luzes parecem feitas da mesma matéria; os objetos representados, relacionam-se com o fundo em pé de igualdade. O vazio é preenchido, modelado, em volta das figuras retratadas. ${ }^{106}$ Captou o núcleo completo da metafísica de De Chirico, recusando a ambígua temática das praças italianas, das musas inquietantes e das perspectivas enganadoras.

O que para De Chirico era um outro espaço, para Morandi era um espaço concreto, saturado, resultante de uma equivalência entre nível e tensão, profundidade e densidade, entre a consciência do próprio ser e do ser no mundo, integralmente vividos por igual, comunicandose entre si, como numa "osmose contínua". ${ }^{107}$

Durante a sua vida, pintou quase as mesmas coisas, garrafas, vasilhas e potes. Fez poucas paisagens e flores, pois eram as paredes, nelas e em torno delas, que o espaço se preenchia e saturava-se de luz e matéria. O ponto de vista de Argan deixa claro a questão da construção espacial de Morandi, que tanto atraiu Adami: "é um trabalho onde a gente sente a força da matéria, do colorido". ${ }^{108}$

De acordo com Maurizio Dell'Arco, Morandi foi um dos primeiros artistas a realmente compreender o sentido de ausência na metafísica de De Chirico e, daquele ponto, ir além. ${ }^{109}$

A pesquisa de Morandi, partindo de um espaço teórico cuja possibilidade de existência pretendia verificar, veio da perspectiva cúbica e vazia da metafísica de De Chirico; mas enveredou por outro caminho. A pintura de Morandi rejeitou a perspectiva fundada na

\footnotetext{
105 ARGAN, Giulio C. Arte Moderna. São Paulo: Cia das Letras, 1992, p.504.

${ }^{106}$ MAMMI, Lorenzo. “Morandi no Brasil”. In Morandi no Brasil. São Paulo: Edições Pirelle, 1995, p.11.

107 ARGAN, Giulio C. Arte Moderna. São Paulo: Cia das Letras, 1992, p.374.

108 Entrevista concedida por Hugo Adami ao artista Antônio Hélio Cabral no Museu Lasar Segall, São Paulo, março de 1976, fita a, p.45.

${ }^{109}$ DELL'ARCO, Maurizio F. The world in a bottle. P. 101.Texto sem mais referências.
} 
geometria euclidiana, isto é, destruiu a concepção espacial sobre a qual, desde Giotto, fundavase a tradição italiana.

Essa perspectiva clássica também já fora negada por De Chirico, que a apresentara significando a nulidade ou o vazio e não a realidade. O processo destrutivo de Morandi é ao mesmo tempo construtivo, porque não só demonstra a sobrevivência do espaço além da perspectiva, como prova ainda que apenas para além da abstração perspéctica, apresenta-se o espaço da consciência como realidade concreta e consciente. ${ }^{110}$

Em seus trabalhos, Adami parece ter herdado de Morandi o abandono da geometria euclidiana, não chegando, porém, a um espessamento de seu espaço, como ocorrido com o pintor italiano. Isto é, a pincelada de Adami e a construção de seu espaço pictórico não se basearam na massa pastosa de tinta, como em Morandi. O pintor paulista construiu sua noção realista de perspectiva por meio do efeito de tatilidade ou volume, ao representar os objetos no espaço. Ou seja, o volume desses objetos era definido por luz e sombra e sutis variações de cor, derivados do tonalismo de Morandi. Isto é claramente visto em suas telas "Arenques defumados” (figura 29), “Cebolas” (figura27), “Concha e Vaso”, e em San Giminiano I (figura 32).

${ }^{110}$ ARGAN, Giulio C. Arte Moderna. São Paulo: Cia das Letras, 1992, p.504. 
III.b. - Exposições na Europa e últimos anos na Itália e em Paris.

Logo que chegou a Florença, Hugo Adami se relacionou com vários intelectuais italianos, e graças a esses contatos, chegou a participar da Décima Quarta Mostra de Arte Internacional de Veneza, em 1924, com o único auto-retrato que fez em sua vida, ${ }^{111}$ (figura 37).

No ano seguinte, participa do Convegno D'Arte em Livorno, com três telas ("NaturezaMorta com vaso e concha", entre elas.); em 1931 participa da V Mostra Regional de Arte em Florença, também com três telas, dentre as quais, uma paisagem intitulada "Positano".

Adami era reconhecido por críticos italianos da época como Verano Magni, Aniceto del Massa e Mário Tinti. Este último declarou:

(...) Adami opera com qualidades instintivas que denotam o pintor de raça, com uma segurança e solidez de forma, com uma vontade e um gosto pela composição, que pressupõem uma capacidade incomum de organização intelectiva, senão espiritual. (... $)^{112}$

Este breve comentário do crítico sobre a pintura do artista brasileiro deixa claro a valorização de alguns elementos ligados ao Novecento, como domínio do métier e o alcance de plasticidade formal.

Outro crítico a falar sobre sua pintura foi Aniceto del Massa, chamando atenção também para o nacionalismo e a composição de Adami:

(...) Hugo Adami, brasileiro de nascença, mas italiano de sangue. A sua educação pictórica se formou entre Florença e Pari s e se apresenta pela primeira vez entre nós com um núcleo de obras, entre paisagens e

\footnotetext{
${ }^{111} \mathrm{O}$ auto-retrato de Adami encontra-se em São Paulo com o colecionador Geraldo Modesto.

112 TINTI, Mário. “Il Convegno D’Arte”. Cronache D’arte, sem mais referências.
} 
naturezas-mortas, nas quais o equilíbrio entre fantasia e disciplina técnica é sustentado com tal vigorosa consciência, para descobrir rapidamente um estilo pessoal, uma linguagem pictórica inconfundível. (...) ${ }^{113}$

Del Massa não privilegia apenas as características plásticas de Adami, mas ressalta o valor do artista em construir uma linguagem própria, deixando evidente o legado de Cézanne aos pintores novecentistas. A propósito, Adami participou em 1926 da primeira exposição novecentista, realizada em Milão, organizada por Margherita Sarfatti.

Em seu depoimento, o artista afirmou que Mussolini ficou meio chateado com as características da pintura de Cézanne encontradas nas obras italianas da exposição:

(...) participei do "Novecento Italiano", aquela famosa mostra que foi organizada por Mussolini, e que foi uma demonstração da pintura italiana, e que estavam todos os valores da pintura naquela época, todos presentes, Carrà, Papini, o De Chirico, todos eles estavam no "Novecento Italiano"; foi justamente nesta ocasião que ele, Mussolini, chegou na exposição, examinou os quadros todos e ficou decepcionado; então chamou os organizadores... a Sarfatti, então, achou que a exposição estava muito influenciada pelos pintores franceses. (.... $)^{114}$

O descontentamento de Mussolini em relação à influência de Cézanne ou de outros pintores franceses não foi sem motivo, já que o objetivo daquela exposição era definir uma arte italiana, colocando-a em lugar de destaque no mundo ocidental, e tiveram êxito, pois a mostra inaugurada em quatorze de fevereiro de 1926, teve uma larga ressonância na Europa. Nessa época, Adami já havia assimilado muito bem os valores da pintura novecentista, e por isso era incluído nas exposições da época, sendo quase sempre lembrado pelos críticos que era um brasileiro, porém, “com sangue italiano". ${ }^{115}$

\footnotetext{
${ }^{113}$ DEL MASSA, Aniceto. "La V Mostra Regionale d'Arte". La Nazione, maio, 1931.

${ }^{114}$ Entrevista concedida por Hugo Adami ao artista Antônio Hélio Cabral no Museu Lasar Segall, São Paulo, março de 1976, fita b, p.25.

${ }^{115}$ Durante a abertura da exposição do Novecento, Adami conta ter sido apresentado a Mussolini por seus colegas artistas e que depois de olhar sua pintura, falou: "O senhor é um bom brasileiro, conheces muito da Itália". Entrevista concedida por Hugo Adami à autora, São Paulo, dezembro de 1999, fita 2, p.2.
} 
Em 1930, Adami participou mais uma vez da Bienal de Veneza (Décima Sétima Mostra Internacional de Arte de Veneza), com dois quadros, um deles, "Natureza-Morta com Lagosta", (figura 23), onde aparece ao fundo, uma paisagem marinha. A sobrinha do artista, Valéria Adami afirmou que seu tio dizia que esse quadro havia sido muito comentado na época, por apresentar uma natureza-morta em primeiro plano, e uma janela grande, aberta, deixando ver ao mesmo tempo, uma paisagem. ${ }^{116}$

Quando esteve mais uma vez em Paris, em 1932, Hugo Adami expôs no Salon des Tuileries com o quadro "Natureza-morta com faisões". Naquele mesmo ano retorna ao Brasil, voltando à Europa apenas em 1937.

Ao revisitar o continente europeu naquele ano, o artista foi direto para Florença. Lá continuou a pintar paisagens como "Positano", de 1937 (figura 33), e naturezas-mortas. No final da década de trinta, mudou-se para Paris, chegando a dividir atelier com Di Cavalcanti. São dessa época, duas naturezas-mortas com frutas: pêssegos, cerejas e morangos, que Adami diz tê-las pintado ao lado de Di, que também as retratou. ${ }^{117}$

\footnotetext{
${ }^{116}$ Entrevista concedida por Valéria Adami, sobrinha do artista, à autora, São Paulo, dezembro de 1999.

${ }^{117}$ Entrevista concedida por Roberto Frizzo, colecionador e amigo do artista, à autora, São Paulo, março de 2001.
} 


\section{CAPÍTULO IV}

\section{A PINTURA DE HUGO ADAMI: NATUREZA-MORTA, PAISAGEM E RETRATO}

Tanto as naturezas-mortas, quanto as paisagens e retratos que Adami pintou no período entre 1923 e 1937, estão intimamente ligados aos elementos da pintura novecentista italiana. Em seus depoimentos, o artista deixava claro a constante preocupação que tinha com os valores estritamente plásticos da pintura, a cor, o volume, a profundidade: “desde a origem eu venho me preocupando com a forma, cor, volume, com a densidade, a distância e profundidade". ${ }^{118}$ A preocupação com o métier, ou o "fazer bem", esteve também presente nos trabalhos desse período, devido ao cuidado que tinha no preparo das telas e tintas e à opção pela pintura a óleo; por ser uma tinta mais maleável e de secagem demorada:

(...) o óleo era muito mais cômodo, pode pintar, raspar, voltar, secar, por verniz, pintar de novo; tem uma série de coisas, é infinita a condição do óleo, por isso achei sempre o óleo uma matéria interessante, porque dá essa condição da gente poder desenvolver ao infinito. Já a aquarela não permite, ela é baseada na luminosidade, naquela frescura, naquela coisa límpida. (... $)^{119}$

A escolha da natureza-morta, da paisagem e do retrato por Adami e os pintores novecentistas, explica-se pela postura que adotaram perante o real, ou seja, para eles, que não mais se consideravam simples observadores "euclidianos", mas inseridos na natureza, interessava-lhes o mundo em que viviam, seu entorno cotidiano, com paisagens, objetos familiares e pessoas de seu convívio, para daí desenvolverem suas poéticas.

Esses gêneros só começaram a receber reconhecimento pelos artistas e o público a partir de quando o gosto burguês inicia um lento processo de consolidação na arte. Os motivos

\footnotetext{
118 Entrevista concedida por Hugo Adami ao artista Antônio Hélio Cabral no Museu Lasar Segall, São Paulo, março de 1976, fita d, p.9.

${ }^{119}$ Ibidem, fita a, p.10.
} 
mais sóbrios ou idílicos ganharam então mais importância para aquela classe: as pessoas próximas, os objetos que possuíam e manipulavam. ${ }^{120}$ A paisagem passa a ser vista como universo a ser explorado pela ciência (a botânica), e se emancipa somente no século XVII, na Holanda, onde trechos de natureza eram representados, sem a presença da figura humana. ${ }^{121}$

Os objetos escolhidos para a pintura de natureza-morta, como a mesa com comida e bebida, as louças, os instrumentos musicais, o cachimbo, os livros, objetos de arte, etc, pertencem a campos de valores específicos burgueses, isto é, o privado, o doméstico, o gustativo, o artístico e, mesmo num clima mais negativo, objetos como a caveira, oferecida em meditação, como símbolo da vaidade, lembrança da vida efêmera e da morte.

O simples fato de se registrar essas qualidades é sugerir um tipo de visão de mundo burguesa. Esses objetos são manipuláveis pelo homem, subordinados a ele, devem sua presença à ação humana, a um propósito; ${ }^{122}$ assim também é a vida para o burguês, um tempo a ser aproveitado, lucrativo, e de preferência prazeroso; é a filosofia do carpe diem.

Os objetos transmitem o sentido do poder humano sobre as coisas, ao produzi-las ou utiliza-las. Quando enaltecidos por uma arte que celebra o visual (valores plásticos), apelam a todos os sentidos, especialmente ao tato e ao paladar. Assim, a natureza-morta é o exemplo de um ponto de vista empírico, segundo o qual o conhecimento humano vem dos objetos próximos, do entorno, do natural. ${ }^{123}$

Essa maneira de pensar vai ao encontro das idéias dos novecentistas e explica porque escolheram expressar-se por aqueles três gêneros da pintura, independentemente desses gêneros encarnarem valores burgueses. A natureza-morta, a paisagem e o retrato davam

\footnotetext{
${ }^{120}$ SCHAPIRO, Meyer. Modern Art: $19^{\text {th }}$ and $20^{\text {th }}$ centuries. New York: George Brasiler, 1974, p.59.

${ }^{121}$ TARASANTCHI, Ruth S. Pintores paisagistas em São Paulo $(1890$ - 1920). Tese de doutorado. São Paulo: ECA/USP, 1986, p.90.

${ }^{122}$ SCHAPIRO, Meyer. Modern Art: $19^{\text {th }}$ and $20^{\text {th }}$ centuries. New York: George Brasiler, 1974, p.61.

${ }^{123}$ Ibidem, p.62.
} 
oportunidade àqueles pintores de desenvolverem aspectos plásticos de sua pintura e a dominar seu métier, dentro de um mundo que os envolvia, servindo de inspiração para suas linguagens. Por essas razões, Adami também adotaria esses gêneros.

Os pintores novecentistas podem ter também privilegiado a paisagem, porque esta mostraria a natureza italiana, agradando seus intuitos nacionalistas, vindos desde a época dos macchiaioli, durante o período da unificação da Itália. ${ }^{124}$

Adami escolheu a paisagem toscana, mais para fins de pesquisa plástica do que pelo nacionalismo na Itália, já que era brasileiro. Tanto que, ao chegar no Brasil, o artista não tentou ver as formas cúbicas da paisagem italiana e adequá-las à paisagem local. Assimilou a cor, a luz e a forma da paisagem do país sendo, contudo, sempre fiel às suas convicções novecentistas que eram: a plasticidade pictórica, o domínio da técnica e a originalidade.

Embora Adami tenha produzido um número maior de pinturas de paisagem, esta análise irá concentrar-se primeiro em suas naturezas-mortas. Isso se dá pelo fato do artista, com esse gênero ter alcançado naquela época, o amadurecimento de seu tonalismo e uma maior liberdade e inventividade em suas resoluções compositivas, sempre observando a metafísica de De Chirico e seu Realismo Simbólico.

${ }^{124}$ Consultar Capítulo I desta dissertação. 
IV.a. - A natureza-morta

Ao referir-se à escolha da natureza-morta como objeto de seu interesse, a afirmação do artista pode levar a uma compreensão incompleta de suas intenções:

(...) eu sempre fiz naturezas-mortas com a preocupação de fazer, de desenvolver bem outros temas, para conquistar justamente profundidade, matéria, densidade, espaço, composição, equilíbrio e tom. (...) ${ }^{125}$

Por enquanto, fica entendido que Adami tenha escolhido a natureza-morta apenas como exercício para desenvolver os elementos plásticos de sua pintura. Ainda mais tendo dito que produziu muitas naturezas-mortas, ou composições com frutas, após estudar três mestres, Leonardo Da Vinci, Michelangelo e Rembrandt: "Michelangelo disse a seguinte frase a um pintor - se você fizer bem uma pera, fará bem centenas de figuras." ${ }^{\prime 26}$

Mas, o artista não teria aprendido com a natureza-morta, apenas a dominar seu métier. Estudou nela, o que apreendeu do contato com a metafísica de De Chirico.

Em 1919, De Chirico retomaria a natureza-morta não só como ponto de partida para o exercício de pura pintura, mas como imagem espectral da realidade, matérias e elementos mortos vivos, ou vivos mortos, chamando a atenção para a efemeridade das coisas do mundo. ${ }^{127}$ De Chirico mostrava em suas naturezas-mortas o "outro tempo", depois da morte; não o triunfo visionário ou paradisíaco, mas o silêncio metafísico, ou seja, mostrava o espetáculo de um mundo habitado somente por livros fechados, esculturas reclinadas,

\footnotetext{
${ }^{125}$ Entrevista concedida por Hugo Adami ao artista Antônio Hélio Cabral no Museu Lasar Segall, São Paulo, março de 1976, fita d, p.46.

${ }^{126}$ Como observou o Professor Lorenzo Mammi, é curioso notar que nenhum desses artistas citados por Adami produziu naturezas-mortas.

${ }^{127}$ Esta preocupação com o efêmero da vida e a existência da morte, seria definida no século XVII como vanitas; também o nome de um tipo de natureza-morta com caveiras ou esqueletos. CALVESI, Maurizio. La metafisica schiarita. Milano: Feltrinelli, 1982, p.256.
} 
ampulhetas implacáveis e bolhas de sabão vagantes, como símbolo/eco da fragilidade revelada do universo. ${ }^{128}$

Assim, para De Chirico, a natureza-morta evocaria um mundo silencioso, isolado e distante, descrevendo a ausência, ou o vazio da morte. Ela seria a composição de um espaço transcendente, suspenso entre morte e vida.

Apesar de não mencionar em nenhum depoimento qualquer outro interesse pela natureza-morta, senão o de exercitar sua pintura, Hugo Adami incorporou em algumas de suas naturezas-mortas sua própria compreensão da metafísica. O artista paulista constrói uma realidade paralela, como um espelho fantasioso, levando o espectador a um estranhamento, causado pela adição de paisagens insólitas ou de objetos não pertencentes ao meio retratado em suas pinturas. (vulcão ao longe - como fundo de uma pacífica cena de faisões mortos - muros medievais alaranjados e estátuas de gesso, ou abóboras na areia das praias).

Por outro lado, mesmo incorporando o que chamava de fantasia ou magia, em suas naturezas-mortas, Adami não se desligava da observação da natureza, do real:

(...) se vê que dentro dessa pintura tem uma certa unidade entre os morangos e a atmosfera lá fora, uma atmosfera de primavera, onde aparecem os morangos... é uma tonalidade primaveril, uma tonalidade alegre...e os tons, todos eles, só tem rosa aqui. (...) ${ }^{129}$

Quando sua intenção era evocar imagens não pertencentes à situação que retratava, recorria aos próprios objetos e à atmosfera real para deles buscar suas lembranças e imagens:

(...) a magia que dos próprios objetos vinha... me levavam a fundos como o mar, o Vesúvio e coisas medievais... tenho naturezas-mortas com castelos, pedaços, coisas de reminiscências de viagens... os objetos

\footnotetext{
128 Ibidem, p.257.

${ }^{129}$ Entrevista concedida por Hugo Adami ao artista Antônio Hélio Cabral no Museu Lasar Segall, São Paulo, março de 1976, fita d, p.48.
} 
levam você para outros mundos, outras visões, outras imagens...então, muitas de minhas naturezas mortas tem um fundo de paisagem... tudo é feito um pouco de memória, em geral, sempre fazendo de fundo. (...) ${ }^{130}$

Adami dizia que os objetos observados sugeriam a tonalidade da natureza-morta, assim como as paisagens imaginárias. Essas características se encontram nas seguintes telas: “Natureza-Morta com Faisões" (figura 8), 1932, "Natureza-Morta com Lagosta", 1930 (figura 23) e “As Artes”, 1925 (figura 24), entre outras.

A primeira pintura citada acima, constitui-se de detalhada composição de um recinto com uma mesa, jarro, frutas e faisões, tendo ao fundo uma janela dando vista a um vulcão em erupção.

$\mathrm{Na}$ segunda, depois da mesa com a lagosta e frutos do mar, abrem-se dois muros de tijolos alaranjados, deixando ver um mar e céu revoltos, com um barco.

Já na pintura “As Artes”, Adami mostra sobre uma mesa, alguns objetos que simbolizam as artes (a pintura, a música a literatura e a escultura). Há também romãs que, segundo a mística cristã, significam a perfeição divina e, sua redondeza, a eternidade; contudo, podem simbolizar igualmente a fecundidade e a sensualidade. ${ }^{131}$ A presença do elmo medieval pode lembrar o poder de invisibilidade de Hades, ${ }^{132}$ ou mesmo a morte invisível, à espreita.

Não parece casual ou simplesmente a título de exercício pictórico, a presença desses objetos e frutos simbólicos, já que todos os demais objetos escolhidos para representar as artes parecem vir da Idade Média ou Renascença primitiva: o alaúde; um canudo de papel e não um livro; uma estátua branca de um torso feminino em estilo clássico. Adami parece querer lembrar uma tradição artística, ou mesmo fazer uma ponte entre a arte clássica da primeira

\footnotetext{
${ }^{130}$ Ibidem, fita d, p.47.

${ }^{131}$ CHEVALIER, Jean. Dicionário de símbolos. Rio de Janeiro: José Olímpio, 1988, p.787.

${ }^{132}$ De acordo com a mitologia grega, o capacete de Hades tornava quem o usasse, totalmente invisível, até mesmo para os deuses. Ibidem, p.184.
} 
Renascença e a arte da época - pois os objetos selecionados para simbolizar a pintura, não são antigos, mas pertencentes a sua época: godê, tubos de tinta óleo e uma garrafa de solvente.

A paisagem de fundo é uma vista toscana da época, mas diante dela, surge um muro semelhante àqueles dos castelos da Idade Média. É intrigante a relação que esses elementos possam estabelecer entre si. Na composição, o torso feminino aparece de frente, mostrando os seios e o ventre e, em diagonal, estão as duas romãs, num colorido róseo, sensual. O elmo corta essa diagonal e impõe-se na composição, contrastando seu volume e tom sombrio com a luminosidade que vem do fundo. Isso faz pensar que simbolize a morte. Está ali como substituto da caveira na vanitas. ${ }^{133}$

Neste quadro há, portanto, o contraste entre vida e morte e entre a eternidade da arte e a transitoriedade da vida (representado na dualidade entre os seios da estátua e as frutas). Por ser tão imponente, o elmo parece querer questionar até mesmo a eternidade da arte, estando ali para lembrar que tudo que é vivo ou mesmo criado pelo homem, pode um dia chegar a perecer, deixar de existir.

Para melhor compreender a concepção metafísica de Adami, seria interessante a comparação entre seu quadro "As Artes” e o quadro de De Chirico, "A sala de Apolo", (figura 25).

Nesse quadro, De Chirico cria um ambiente de solidão e ausência, por meio da perspectiva de Piero Della Francesca. Seu fundo lembra muito o pórtico da "Flagelação de Cristo" de Piero (figura 26). De Chirico acreditava que para criar um espaço isolado, ausente, teria que recorrer à arquitetura e perspectiva dos clássicos renascentistas. No primeiro plano, estão representados um violino, uma partitura musical e um busto em estilo clássico.

\footnotetext{
133 Tipo de natureza-morta que mostra a imagem de caveiras ou ossos contraposta a imagens de seres vivos e jovens ou a de frutas recentemente colhidas, como alegoria da morte ou brevidade da vida. Fala das vaidades e glórias do mundo terreno, lembrando de sua perenidade. Além da caveira, podem aparecer símbolos como colunas derrubadas, campos em ruínas ou a ampulheta. REVILLA, Federico. Diccionario de Iconografía y simbologia. Madrid: Cátedra, 1999, p.446.
} 
É possível ver que De Chirico pretendia referir-se à antigüidade clássica, devido ao tema da pintura e da perspectiva renascentista. Sua composição mostrava um espaço isolado da realidade, suspenso, em total silêncio. Mesmo evocando Apolo, o deus da música, o violino de De Chirico não estava representado num momento ou situação que estivesse disponível para ser tocado, mas encontrava-se isolado naquele espaço ausente de vida.

As naturezas-mortas de De Chirico nessa época, derivadas da metafísica, habitavam um tempo e um espaço suspensos, fora da realidade. Mesmo referindo-se à história, por englobarem a mitologia grega e os clássicos, encontravam-se isoladas, à parte, em sua existência absoluta, cristalizada.

Já as naturezas-mortas de Adami, aproximavam aqueles objetos simbólicos ou mesmo de referência histórica, da realidade presente. Ao organizar, numa mesma composição, os objetos quietos e silenciosos das naturezas-mortas com o movimento dos mares revoltos, do vulcão em erupção e as vistas cotidianas, triviais, o artista criava um elo entre eles.

As dualidades, presença/ausência; fantasia/realidade e vida/morte, não se separam na pintura de Adami, mas convivem em harmonia. Assim, o artista não suspendia sua natureza-morta em um espaço e tempo herméticos, silenciosos, mas a trazia para o ritmo natural das coisas.

Quando não tratam de elementos da metafísica, as naturezas-mortas de Adami apresentam grande preocupação tonal, herdado de Morandi. Embora admirasse o espaço denso desse pintor italiano, ficou ainda ligado à construção do volume e solidez pela luz e sombra, e não pela corporeidade da tinta ou materialidade da luz, como mencionado no capítulo anterior.

Em suas naturezas-mortas, Adami constrói o espaço pela noção de profundidade e volume das figuras, utilizando-se da gradação e combinação de cores e com a luz e sombra. Embora não seguisse piamente a perspectiva euclidiana, seus trabalhos diferenciavam de Morandi e Cézanne, quanto à organização espacial. Os objetos em suas naturezas-mortas, pareciam ter sido colocados na tela, um a um, dando a impressão de poder serem tocados. 
Seus garrafões herdam o brilho e a textura lisa do vidro, assim como a concha cor de rosa em “Concha e Vaso", lembra a superfície lisa do modelo.

As figuras pintadas por Adami possuem tatilidade. Em "Cebolas", (figura 27), o pano branco adquire volume; a composição é resolvida por uma combinação de cores apurada e suave. Como dizia Mário de Andrade, ali pulsava pura plasticidade. ${ }^{134}$ Para ficar mais clara a solução volumétrica de Adami por meio da luz e sombra, o trabalho de Casorati, "Ovos sobre baú" de 1920, (figura 28) deve ser lembrado.

Essa obra de Casorati tornou-se quase um emblema, uma síntese de idéias novecentistas. Os quinze asteróides de um branco calcinado, agrupados sobre um plano de madeira escura, podem figurar como a tendência pictórica mais concisa e mais evidente de um mundo de fantasia, da representação, que o artista resumiu com o seguinte dizer: número ou ritmo, peso, quantidade ou massa. ${ }^{135}$

É uma pintura que indica os resultados acurados, os quais foram os novos orientadores da pintura da época. O diálogo entre luz e espaço, entre cor e forma, se tornou mais próximo. Pode-se distinguir o novo curso da luz vindos dos efeitos que ela produz, a começar pela sombra.

Na base do baú, em primeiro plano, as sombras contribuem com a luz para criarem um ligeiro movimento rítmico. Sobre o plano da caixa, a sombra levada de um canto da moldura, se alonga e esvanece como a sombra de uma luz meridiana e induz a pensar em valores ambíguos de verdade e ilusão. Em torno dos quinze ovos, a sombra começa como uma notação científica, mas se conclui como zona de cor intensa e mais grave, utilizada para dar relevo e vivacidade. A sombra, deste modo, deixa de ser a contraposição da luz, transforma-se em complemento ou qualidade da luz.

\footnotetext{
${ }^{134}$ ANDRADE, Mário de. "Hugo Adami”. Diário Nacional. São Paulo, 11/09/1928, p.9.

${ }^{135}$ CARLUCCIO, Luigi. La faccia nascosta della luna. Itália: Umberto Alemandi \& Cia, 1974, p.142.
} 
Em "Cebolas" (figura 27) e "Arenques defumados" (figura 29), de Hugo Adami, é evidente a função coadjuvante da sombra em relação à cor, como nessa pintura de Casorati.

O pintor paulista elabora seu espaço por continuidade, por meio de seu tonalismo e não por contrastes de cor modulados por pinceladas fragmentadas, como em Cézanne, ou por meio da massa luminosa de Morandi. Constrói como Casorati, um espaço preenchido passo a passo, por cores, luz e sombra, dando a impressão de volume.

O espaço pictórico concebido por Adami e Casorati difere também daquele de Morandi, pela densidade e intensidade com que esse último tratou a massa de tinta. Poderia ser dito que a pintura de Morandi é opaca e as de Adami e Casorati, ainda apresentam uma atmosfera límpida, transparente, devido à definição do volume ser dada pela luz e sombra sutis, e não pela massa pictórica.

Com suas naturezas-mortas, Adami teve êxito em seu projeto de aprimorar sua linguagem plástica, pois nelas não se vê apenas representação realista, mas a preocupação com o tratamento de elementos inerentes à pintura, como cor, luz e sombra, composição e forma.

Adami prezava a harmonia entre os componentes de sua pintura, e não haveria nenhuma forma mais harmônica do que os contornos arredondados das frutas, cebolas e ovos.

Segundo o crítico Luigi Carluccio, a forma arredondada ou oval é tão importante quanto o manequim de De Chirico ou às garrafas de Morandi. Nenhuma outra figura, senão o ovo, exprimiria com tanto rigor a forma na sua plenitude absoluta, sem saliências, em seu equilíbrio alcançado, no perfeito domínio do espaço que sugeria. ${ }^{136}$

O ovo casoratiano, segundo Carluccio, se transformou no modelo de uma substância viva, sem distúrbios, absorta e concluída em sua racionalidade e distância platônica. Não é

${ }^{136}$ Ibidem, p. 149. 
somente um esferóide dado a significar uma espécie de quintessência plástica num certo senso ainda ambíguo, mas é o símbolo, o fenômeno evidente de uma realidade que se libera da paixão e é todo contido na linha contínua de sua racionalidade. É ainda o símbolo do destaque, do cálculo, a figura mais feliz pelo motivo que o artista havia escolhido como registro de sua visão da arte e da vida, ritmo, dimensão e quantidade, condensados em um único contexto formal. ${ }^{137}$ A partir da figura do ovo, fica ainda mais fácil compreender a harmonia espacial e tonal conseguida por Adami em suas naturezas-mortas. Sua composição é macia, ou seja, o olhar passa sem turbulência, sem cortes abruptos, de uma forma a outra, de um tom a outro. Suas sombras e cores sutis harmonizam côncavos e convexos, cheios e vazios, dando às suas figuras, volume, brilho, tatilidade. Adami consegue obter em sua representação, o equilíbrio clássico e sóbrio, ao criar um espaço onde as formas se encaixam e harmonizam, por meio das gradações de cor.

Esse equilíbrio tonal e espacial de Adami poderia ser sintetizado pelo quadro "Virgem e santos com Federico de Monte Feltro", de Piero Della Francesca, (figura 30) onde, ao fundo, no alto, se encontra uma grande concha em perspectiva, tendo sua parte côncava indicada pela luz e sombra; e de sua crista, na parte central, pende, em contraste, um pequeno ovo, descrevendo todo o equilíbrio da composição em sua forma convexa - equilíbrio entre cheio e vazio, grande e pequeno, espaço e luz.

${ }^{137}$ Ibidem, p. 150 . 


\section{IV.b. - Paisagens e Retratos}

É difícil olhar para as pinturas de paisagens de Hugo Adami sem ver nelas a lição de Cézanne. Como em suas naturezas-mortas, o pintor paulistano encontrou na paisagem o volume e a solidez da forma plástica, com o auxílio do mestre francês.

Bem cedo em suas pesquisas Cézanne descobriu que, do Impressionismo, poderia e deveria nascer um novo Classicismo, não mais fundado na imitação escolar dos antigos, e sim dedicado a formar uma imagem nova e concreta do mundo, procurada não na realidade exterior, mas na consciência.

Segundo Argan, Cézanne não podia pensar a realidade, senão enquanto fosse recebida por meio da consciência, e não podia pensar a consciência, se não viesse preenchida pela realidade. $^{138}$

A ponte sugerida por Cézanne entre a consciência e a realidade, seria portanto, olhar ou tratar esta última, por meio do cone, da esfera e do cilindro; formas racionais, pertencentes à consciência humana. Contudo, Cézanne não afirmou que se devesse reduzir as aparências naturais à formas geométricas, ele não se referia a um resultado, e sim a um processo, As formas geométricas, expressivas do espaço, eram instrumentos mentais com que se efetuava a experiência do real. Isto é, se uma laranja, no quadro, aproxima-se da esfera, ou uma pera, do cone, não significa que a laranja seja esférica e a pera cônica, mas que o artista conseguiu especificar a relação entre os dois objetos singulares e o conjunto da realidade. Ou seja, fazer com que essa laranja e essa pera, sejam uma laranja e uma pera, e uma esfera e um cone simultaneamente.

${ }^{138}$ ARGAN, Giulio Carlo. Arte Moderna. São Paulo: Cia das Letras, 1992, p.113. 
Como as formas geométricas não são o espaço, mas meios pelos quais o homem pensa o espaço, elas não são idéias inatas, e sim formas históricas; e assim, fortalecida pela sua característica histórica, a consciência se apresenta para a experiência do real presente. ${ }^{139}$

Adami parece ter assimilado bem essa lição de Cézanne, pois afirmou que pintava sempre observando o real, tinha a necessidade de integrar-se à atmosfera e, ao mesmo tempo, de não copiar o que via, mas buscar uma ordem formal pelo volume:

(...) estive lá em Assis pintando aquela arquitetura medieval... ficou intacta, a paisagem é a mesma, os ciprestes são os mesmos, aquelas casas dos camponeses, aquela beleza, aquela simplicidade, que são as casa dos camponeses, aqueles campos geométricos! Tudo no lugar, essa disciplina, a ordem que tem dentro daquilo tudo... toda aquela paisagem sombria, tem uma ordem... A gente percebe aqueles campos geométricos, os planos todos, está tudo pronto para você pintar... tal é a ordem e a disciplina... você vê a atmosfera limpa... você percebe os mínimos detalhes de casa, de árvores, cheio de árvores, no fundo de um cristalino limpo, impressionante aquela atmosfera, e assim foi que eu pintei Assis. (... $)^{140}$

Nesse trecho, fica claro o interesse que Adami tinha pelos "campos geométricos" da paisagem toscana. Todas as suas paisagens produzidas na Itália, entre 1924 e 1937, aproximadamente, (figuras 31, 32 e 33), mostram essa preocupação com o geométrico, com o volume e a profundidade. Todas as casas são apresentadas em formas quadradas ou cúbicas. A profundidade é conseguida por diferentes planos ordenados, onde ainda é possível diferencialos pela perspectiva - criada mais pela luz e sombra do que por pontos de fuga.

Cézanne chegou a uma resolução formal facetada, composta por pequenas pinceladas de cor, ou seja, diferentes tons criavam a noção de volume e espaço por contraste, e não por luz e sombra, como no caso de Adami. Cézanne dava o primeiro passo que iria romper de vez

\footnotetext{
${ }^{139}$ Ibidem, p.112.

${ }^{140}$ Entrevista concedida por Hugo Adami ao artista Antônio Hélio Cabral no Museu Lasar Segall, São Paulo, março de 1976, fita e, p.4.
} 
com a perspectiva euclidiana, pois, ao negar a luz e a sombra, começava também a negar a representação naturalista. ${ }^{141}$

Mas o objetivo de Hugo Adami não era revolucionar a linguagem pictórica, mas encontrar nela o que entendia por "essencial": simplicidade e sobriedade. Para os novecentistas, o excesso na pintura traduzia-se pela efusão de cores e o caráter cientificista da pintura Impressionista, e nos arroubos ou ousadias das vanguardas. Portanto era necessário retornar ao comedimento e disciplina dos clássicos (sem desprezar é claro, algumas conquistas formais da pintura, conseguidas por Cézanne). Esse pensamento, compartilhado entre os novecentistas e Adami, derivou das diretrizes anti-românticas dos macchiaioli, no século XIX, então novamente em voga naquela primeira metade do século XX. ${ }^{142}$

Ao falar sobre sua produção de paisagens feitas no Brasil, os objetivos do artista em relação à pintura, ficam mais claros:

(...) queria fazer uma pintura mais profunda, mais análise, mais ordem...mas, a nossa paisagem é toda desorganizada... o artista tem que aliar as leis de harmonia, de equilíbrio, geometria, porque pintar a paisagem toscana é sopa, ela está pronta, ela está feita, é a mesma de Masaccio, a de Giotto, aquela gente, dos homens da Renascença, as casa dos campônios têm a mesma arquitetura, a mesma coisa, então ali é fácil, mas aqui a nossa natureza é toda, toda... bagunça, toda desordem, com ausência de geometria, então tem que eliminar, tirar umas tantas coisas, fazer só o essencial... não é fácil. (...) $)^{143}$

Em uma de suas paisagens brasileiras, produzida entre 1932 e 1937, "Pico da Vitória" (figura 34), é possível perceber o contraste entre a paisagem toscana, produzida anteriormente, com sua lógica geométrica, e a paisagem brasileira, caótica e orgânica.

${ }^{141}$ TASSINARI, Alberto. O espaço moderno. São Paulo: Cosas \& Naiffy, 2001, p.21.

142 TARASANTCHI, Ruth S. Pintores paisagistas em São Paulo $(1890$ - 1920). Tese de doutorado. São Paulo: ECA/USP, 1986, p.96.

${ }^{143}$ Entrevista concedida por Hugo Adami ao artista Antônio Hélio Cabral no Museu Lasar Segall, São Paulo, março de 1976, fita d, p.9. 
Adami harmoniza sua representação por meio de um tonalismo sutil. Ao pintar no Brasil, o artista parece deixar de lado a premissa de Cézanne, que dizia para tratar a natureza pela visão geometrizada da razão. Rende-se à sensualidade da forma orgânica, ou ao que chamava de "sensualidade latina" na pintura. Dizia que os pintores toscanos, venezianos e os franceses (Renoir), apreciavam as formas sensuais como as curvas das frutas e das mulheres.

Por outro lado, sem dúvida, deixou-se envolver pelo nacionalismo e questões sociais do Modernismo brasileiro dos anos trinta. Isso é claro na escolha de seus temas e também no fato de trazer para a sua pintura temas da realidade brasileira. Pintou uma fábrica, uma vista de favela "Favela dos meus Amores", (figura 35) e um rapaz fugitivo da polícia, "O Fugitivo". ${ }^{144}$ Adami manteve o apuro colorístico e formal conquistado na Itália, nas paisagens que produziu aqui no Brasil. Uma dessas paisagens, "Fábrica", de 1934 (figura 36), é muito interessante, porque nela, o pintor parece relembrar a imaginação herdada da metafísica.

Apresenta um galpão retangular industrial de onde sobe um grupo de chaminés alaranjadas, desprendendo linhas horizontais de fumaça. A perspectiva é inusitada nesse trabalho, comparada com todos os demais encontrados nesta pesquisa. O caminho descrito do rodapé da pintura até a fábrica, foi feito em forma de semi-círculo, acentuando a bidimensionalidade do chão. Essa perspectiva chapada, só é atenuada por dois montes de areia: um maior, à frente, e o menor, atrás, dando idéia de profundidade. As sete chaminés imponentes e as janelinhas enfileiradas do galpão, lembram muito a solidão metafísica dos quadros de De Chirico ou mesmo alguns de Sironi. As chaminés só quebram seu silêncio, por despejarem na área estática de céu azul, linhas horizontais de fumaça branca.

\footnotetext{
${ }^{144}$ Nessa época Adami auxiliava a produção dos cenários do filme "Favela dos Meus Amores", de Humberto Mauro, no Rio de Janeiro; e deu a seu quadro o mesmo título do filme.
} 


\section{Retratos}

Embora Adami tenha dito, em seu longo depoimento a Antônio Hélio Cabral, que pintou muito mais paisagens e retratos do que naturezas-mortas, não foram encontrados muitos de seus retratos. Parece que a preocupação plástica encontrada em suas demais pinturas, estende-se também para esse gênero. Suas cores continuam sensuais e suas formas obedecem aos traços do modelo observado. $\mathrm{O}$ apelo tátil permanece.

Em seu único auto-retrato, datado de 1923 (figura 37), o artista define a composição por meio de um tonalismo primoroso entre o rosa, o lilás e o negro. A luz e sombra, sutilmente empregadas na pintura, lhe conferem a impressão de volume. Já em "Fugitivo" (figura 39) e "Figura de mulher" (figura 38), da década de trinta, as figuras parecem estar mais envolvidas pelo fundo e não volumetricamente destacadas dele como no auto-retrato.

Em "Fugitivo" essa interação entre fundo e figura se faz por meio de uma languidez que invade toda a obra. A terra do chão, a calça branca do moleque e seu corpo são definidos por contornos macios, sendo essa maciez reforçada pelo azul esmaecido dos troncos de árvore que rodeiam a figura do rapaz. Tudo ali convida ao sono pesado de um dia de calor. Mas essa tranqüilidade é rompida por um tom de laranja berrante e chapado, que vem do fundo. Esse laranja - herança do simbolismo de De Chirico - pode ser entendido como a metáfora da condição ameaçadora que rodeia o garoto e, da qual, ali, rodeado por grossas árvores azuladas e mergulhado no sono, está protegido.

Ao rever as pinturas de Adami, realizadas entre 1923 e 1937, parece justo afirmar que elas foram marcadas por duas correntes novecentistas definidas por Marco Lorandi como a neocezanniana e a neo-renascentista. ${ }^{145}$ Contudo, sua produção pictórica não deve ser classificada como exemplo específico de uma ou de outra.

${ }^{145}$ Sobre essa questão, ver Capítulo II desta dissertação. 
O que houve na formação de Adami, foi a absorção de várias idéias que circulavam entre os novecentistas na Itália, nem sempre seguidas à risca pelo artista.

Com certeza, seu trabalho dialogou com os de Cézanne, Morandi, De Chirico e os pintores renascentistas, mas tendo sempre em vista o desenvolvimento de uma linguagem pessoal, a não deformação da figura, ou a preservação do Naturalismo - mesmo que idealizado, em suas pinturas simbólicas - e o aprimoramento plástico.

Essas idéias eram típicas dos pintores do Novecento Italiano, e caracterizaram a corrente de Retorno à Ordem na Itália. E foi dentro desse novo Realismo, que Adami produziu grande parte de suas pinturas. 


\title{
CAPÍTULO V
}

\section{HUGO ADAMI NO BRASIL: ANOS 20/40}

\author{
V.a. - De volta à terra do Pau Brasil
}

No ano de 1927, quando Adami volta de sua primeira viagem à Europa, o Brasil estava às vésperas de grandes mudanças políticas. Durante toda a República Velha (1889-1930), o desenvolvimento econômico local passou a depender cada vez mais das atividades urbanas, sobretudo aquelas do setor industrial. Contudo, a política do governo continuava privilegiando os lucros das atividades agrícolas, em detrimento da indústria. O domínio político dos fazendeiros garantia o protecionismo agrícola, embora os industriais reclamassem e suas queixas encontrassem eco em boa parte da população urbana. Por essa razão, o crescimento da produção nas cidades intensificou a pressão por mudanças.

São Paulo tornava-se um grande pólo industrial no país, tendo sua indústria e população crescido muito rápido durante as primeiras décadas do século XX. Sendo um dos maiores centros econômicos brasileiros, a cidade foi também palco de transformações culturais.

Oswald de Andrade e Tarsila do Amaral já haviam desenvolvido o movimento Pau Brasil, que apresentou um novo direcionamento para o Modernismo brasileiro: redimensionar o Modernismo local para a criação de uma arte moderna nacional. Não bastava mais romper com a arte realista/naturalista aburguesada da época e atualizar a inteligência brasileira; ser moderno, no Brasil, era buscar e caracterizar sua própria identidade em relação ao mundo ocidental. A absorção que Tarsila fez do pós-Cubismo esteve intimamente ligada à apreensão do Brasil. "Vendo com olhos livres", como dizia o manifesto Pau Brasil, a pintura de Tarsila 
demarcava a paisagem brasileira, reelaborando-a em termos pictóricos, fundindo o estilo pósCubista a elementos populares. ${ }^{146}$

Na busca de elementos nacionais, os modernistas da época iriam apegar-se à expressões da cultura popular, como o circo. Separavam por meio de sistematização, valores da cultura popular que julgavam válidos para a cultura erudita. Isto é, colhiam informações da estética circense. Essa adesão da criação artística à cultura popular, não significou conformar-se e aterse ao nível cultural do povo, mas transferir para a esfera erudita os seus valores para que, transformados, pudessem agir e refletir sobre a nação. ${ }^{147}$

Valorizando o circo, os modernistas da época estabeleceram contato com um famoso palhaço da época: Piolim. O palhaço interessava aos modernistas por ser brasileiro, produto nacional, e assim aprendiam com ele humorismo e estudavam a psicologia do brasileiro. Freqüentavam o circo de Piolim e o levavam para passeios e reuniões. Uma dessas ocasiões foi um almoço dado em sua homenagem, em março de 1927, no Mappin Stores, do qual Hugo Adami participou. O almoço não só homenageava o palhaço, mas tratava-se também do primeiro evento social do Clube de Antropofagia.

Para Mário de Andrade, a figura de Piolim condensava algumas características do típico brasileiro, servindo para definir alguns de seus personagens na literatura, como Macunaíma e Pedro Malazarte. Mas seu objetivo de criar uma identidade brasileira e assim dar feição ao Modernismo se estendia não só à literatura, mas também as artes plásticas.

Segundo Tadeu Chiarelli, Mário de Andrade seria o crítico a tornar clara a empreitada modernista, de conectar as artes plásticas no Brasil com o mundo e ao mesmo tempo, não perder as características nacionais.

\footnotetext{
${ }^{146}$ FABRIS, Annateresa. O Futurismo Paulista. São Paulo: Perspectiva, 1994, p.215.

${ }^{147}$ LOPEZ, Telê Porto A. "Os modernistas de São Paulo e o Circo”. Suplemento Literário, O Estado de São Paulo, 26/04/1969.
} 
Para tanto, do ponto de vista de Andrade, o Modernismo paulistano não poderia aderir simplesmente às correntes mais radicais das vanguardas européias - que negavam a noção vigente de arte como representação da realidade exterior - pois tal adesão impossibilitaria que os modernistas, no campo das artes plásticas, construíssem uma iconografia brasileira. ${ }^{148}$

Desse modo, impossibilitados de aderirem incondicionalmente ao Realismo/Naturalismo das correntes brasileiras alternativas do período anterior, e impedidos por outro lado - de aderir aos contornos mais radicais das vanguardas históricas, teria restado aos modernistas abraçar as tendências de Retorno à Ordem que, como foi visto, passavam a dominar a Europa, a partir do final da Primeira Guerra Mundial.

Como os avanços estéticos das vanguardas de modo geral direcionavam a produção artística para o Abstracionismo, Mário de Andrade escolheu para a idealização do Modernismo no Brasil, os elementos das correntes de Retorno à Ordem condensados, sobretudo nas teorias de Jeanneret e Ozenfant.

Uma das principais publicações européias, ligadas a esse clima restaurador e que Mário de Andrade selecionou e estudou, foi a revista francesa L’Esprit Nouveau, fundada em 1920 pelos artistas Amedèe Ozenfant e Charles Edouard Jeanneret (Le Corbusier), em circulação até 1925. ${ }^{149}$

Os dois artistas citados, criadores do Purismo, afirmavam que o Cubismo se tornara uma arte decorativa, de ornamentalismo romântico e que, na hierarquia da arte, seu "decorativismo" ficaria na base da hierarquia da arte.

Diziam igualmente que a pintura era boa quando as qualidades de seus elementos plásticos superavam suas possibilidades de representação ou narrativa.

\footnotetext{
${ }^{148}$ CHIARELLI, Tadeu. "Entre Almeida Jr. e Picasso". In FABRIS, Annateresa. Modernidade e Modernismo no Brasil. Campinas: Mercado de Letras, 1994, p.62.

${ }^{149}$ CHIARELLI, Tadeu. De Almeida Jr à Almeida Jr. Tese de doutorado. São Paulo: ECA/USP, 1996, p.30.
} 
O Purismo expressava o invariável, ou seja, o trabalho não deveria ser acidental, experimental, impressionista ou pitoresco, mas, pelo contrário, geral, estático. O Purismo almejava conceber claramente, executar lealmente, sem falsidade. Ele abandonava concepções desordenadas, execuções ásperas, sumárias.

A arte consistia, segundo Jeanneret e Ozenfant, antes de qualquer coisa, na concepção. A técnica era apenas uma ferramenta, subordinada a seu serviço. O Purismo temia o bizarro e o original, já que procurava o elemento puro no sentido de reconstituir pinturas organizadas que deveriam ser elas próprias, fatos da natureza. O método deveria ser correto o suficiente para não obstruir a concepção. O Purismo não acreditava que retornar à natureza significasse copiala.

Ele admitia que toda deformação fosse justificada pela procura do invariável. Concebido como uma superação imediata do Cubismo e de todas as outras tendências de vanguarda que o antecederam, o Purismo propunha uma arte pautada em valores plásticos absolutos, não estabelecendo, porém, o afastamento total do referencial da natureza. ${ }^{150}$

Posicionando-se a favor de uma arte que não admitia o contingente, o circunstancial, a experimentação técnica e estética, tal movimento tendia nitidamente para uma proposta de arte clássica que significava recuperar aquilo que se acreditava ser a grande tradição da visualidade francesa, o caráter nacional da arte naquele país. Para os puristas e grande parte dos artistas franceses da época, a nova arte do pós-guerra, deveria tentar revitalizar a arte francesa, voltando a artistas que engrandeciam a tradição do país, como Poussin, Chardin, Dominique Ingres e Courbet. ${ }^{151}$

\footnotetext{
${ }^{150}$ Ibidem, p.31.

151 Ibidem, p.31.
} 
Ao observar a definição da filosofia purista e o que propunha para a linguagem plástica, ficam evidentes vários pontos de contato entre ela e os ideais dos novecentistas, resumidos em uma outra revista aqui já mencionada: Valori Plastici.

Em alguns artigos dessa revista, fica claro o desejo de reafirmar a concepção da arte como experiência tradicional italiana, por meio de um grupo heterogêneo em formação, mas ciente da crise da Modernidade e das experiências de vanguarda do início do século. Queriam uma arte alternativa, em nome de um "novo" ou renovado Classicismo.

Almejava a formação de uma arte e de uma cultura figurativa, guiadas por um repensar radical do fazer em pintura, pela valorização do métier e de valores eternos da arte, como os valores essencialmente plásticos da pintura. ${ }^{152}$

Assim, ao deparar-se com as pinturas de Hugo Adami, em setembro de 1928, em uma exposição individual que o artista apresentava na Casa das Arcadas, em São Paulo, Mário de Andrade reconheceria nelas toda a prática das teorias de Retorno à Ordem que estudara e escolhera para fundamentar a sua própria proposta para uma arte moderna brasileira.

Parece que Hugo Adami foi o primeiro artista moderno que Mário de Andrade encontrou, cuja produção pictórica - impregnada pelo respeito aos valores intrínsecos da pintura - estava ligada às correntes tipicamente realistas do Retorno à Ordem internacional. Até então, o crítico apenas pudera ter contato com esta vertente através de reproduções fotográficas. ${ }^{153}$

A ressonância imediata da pintura de Adami sobre Mário de Andrade foi enorme, mas não tão duradoura quanto o interesse que lhe despertaram a pintura Pau Brasil de Tarsila, a pintura de Lasar Segall e mesmo o trabalho de Portinari na década posterior.

\footnotetext{
${ }^{152}$ FOSSATI, Paolo. Valori Plastici: 1918 -1922. Torino: Einaudi, 1982, p.4.

${ }^{153}$ CHIARELLI, Tadeu. De Almeida Jr à Almeida Jr. Tese de doutorado. São Paulo: ECA/USP, 1996, p.42.
} 
Segundo Tadeu Chiarelli, pode-se inclusive deduzir que o interesse primeiro de Mário de Andrade pelas pinturas de Cândido Portinari e Vittorio Gobbis no Salão Modernista carioca de 1931 deveu-se, pelo menos em parte, à compreensão da arte de fundo realista de Hugo Adami. ${ }^{154}$

Comparando a pintura de Adami com aquela de Fernand Léger, também em seu período de Retorno à Ordem, nos anos vinte, Mário de Andrade tentou confrontar aquela tendência pictórica que estava vendo pela primeira vez frente a frente (pinturas de Adami) com obras até então estudadas por meio de reproduções (Léger dos anos vinte). Apesar da retomada de Léger de uma figuração mais convencional, sua pintura possuía, sem dúvida, um grau de síntese maior de que aquela de Adami, ${ }^{155}$ o que de início preocupou um pouco Andrade, já que defendia mais certas deformações da figura, do que o Realismo.

Porém, essa comparação parece ter sido a única maneira encontrada por Andrade de enquadrar a obra de Adami dentro de um repertório "moderno", ou dentro daquilo que entendia como tal: uma pintura que não se interessava pelos radicalismos das experiências das vanguardas e adotava a representação do real despida do caráter anedótico.

É preciso salientar o fato de Mário de Andrade escrever que, para ele, não importava a semelhança da representação pictórica de um pêssego pintado como um pêssego de verdade, abrindo mais uma vez a possibilidade para que a pintura de preocupações analógicas adentrasse de maneira sutil o universo de suas preocupações estéticas. Isto seria fundamental, de acordo com Chiarelli, para a constituição de seu interesse por uma pintura que, moderna (isto é, nem anedótica e descritiva, mas igualmente, não experimental e tendente ao Clássico), fixasse as peculiaridades físicas e humanas do país:

\footnotetext{
154 Ibidem, p.44.

155 Ibidem, p.45.
} 
(...) Eu falei que Hugo Adami tinha um caso psicológico bem complicado e que na Europa, se preocupou principalmente em adquirir o metiê dele.

Com efeito, está com uma técnica tamanha que chega à virtuosidade. Se observe a variedade estupenda com que maneja o pincel. Adquiriu o valor objetivo que quer. A interioridade de certos pêssegos, a dureza quebradiça, sem elasticidade da "Concha", o valor tactil dos panejamentos provam a variedade inventiva com que ele consegue por meios plásticos reproduzir exatamente a sensação objetiva. Tudo isso, sob o ponto de vista propriamente pictural me parece uma ninharia e hei de preferir sempre um pêssego de verdade embora pareça com pirarucu a uma abóbora de quadro parecendo bem abóbora mesmo.

Porém, essa ninharia era falsa se Hugo Adami pintasse os excelentes "Arenques Defumados", unicamente prá pintar arenques parecidos com os tais. Mas é que peixes, ovos, casas chão, adquirem quase sempre valores plásticos absolutos e livres. Não faz mal que um pêssego de pintura se pareça com um pêssego de verdade, contanto que na pintura ele viva um valor plástico essencial (...) Hugo Adami pinta exatamente "naturezas-mortas". Por mais que uma abóbora, uma cebola, estejam silenciosamente vivendo, cada um por si, Hugo Adami assassinou a natureza. O que está vivendo é o quadro como objeto plástico e nada mais. (...) ${ }^{156}$

Continuando a análise das obras, Mário de Andrade irá afirmar que preferia as naturezas-mortas de Hugo Adami às suas paisagens italianas, por considerar essas últimas mais convencionais. Porém, valorizava as paisagens que ele já havia pintado no Brasil:

(...) São quadros sem nada do convencionalismo estético ou da boa educação falsa com que nacionais e estrangeiros andam malbaratando o pão de Açúcar, a terra roxa. O mercado de Peixe de Belém, ou a Rosário de Ouro Preto. Mais que a paisagem, esses quadros expressam o sentimento de alma que o pintor sentiu mirando a tal. Eles manifestam uma expressão de tragicidade bem intensa. (...) $)^{157}$

Parece que Mário de Andrade percebeu no paisagismo não anedótico de Adami, segundo Chiarelli, a possibilidade de captar a natureza física do Brasil sem os prejuízos da descrição detalhada, mais comum na pintura brasileira do século XIX e início do XX.

Para Andrade, Hugo Adami parece ter sentido e expressado por meios puramente plásticos o drama da paisagem brasileira.

O crítico tentou compreender a objetividade do pintor como uma tendência eterna dentro da história da arte, uma tendência que se manifestava na cena contemporânea da época.

\footnotetext{
${ }^{156}$ ANDRADE, Mário. “Hugo Adami”. Diário Nacional. São Paulo, 11/09/1928, p.9.

${ }^{157}$ ANDRADE, Mário. "Hugo Adami”. Diário Nacional, setembro de 1928.
} 
Assim, Mário de Andrade percebeu que não era mais possível entender o Realismo e o Realismo/Naturalismo com preconceito. Era necessário reintegrar essa corrente dentro do campo de validade da arte moderna, uma vez que nela podiam ser percebidos certos valores eternos da arte. $^{158}$

O crítico cindiu seu próprio conceito de Modernidade para que, transformado em duas correntes, nele coubessem seus aspectos plurais e até um pouco antes antagônicos: de um lado Hugo Adami, um realista não-anedótico e do outro, Lasar Segall, um realista mais expressionista, engajado na busca de uma síntese entre as estruturas do fato plástico e as suas preocupações de ordem social:

(...) Pois creio que essa sensualidade primordial no pintor, foi o que o tornou tão plástico. Talvez Hugo Adami seja o mais exclusivamente plástico dos pintores modernos que têm exposto em São Paulo. Lasar Segall, por exemplo, que eu considero declaradamente um mestre, une à plasticidade um valor expressivo social formidável. $(\ldots)^{159}$

Tadeu Chiarelli demonstrou claramente a importância que a pintura de Hugo Adami representou para auxiliar Mário de Andrade a definir sua própria idéia de Modernismo.

Ao ver pessoalmente as obras do artista, o crítico pôde conceber com clareza suas diretrizes para o Modernismo no Brasil, um Modernismo ligado à representação não literal do real circundante.

Mais tarde, Andrade abandonaria as pinturas de Adami e Segall, para eleger a obra de Cândido Portinari como aquela que englobava todos os caracteres que definiam sua concepção de Modernismo ideal para o Brasil: valorização de elementos plásticos ou eternos na pintura, e ao mesmo tempo, a representação de elementos tipicamente brasileiros, evidenciando assim, o elemento nacional, característico de uma identidade brasileira.

\footnotetext{
${ }^{158}$ CHIARELLI, Tadeu. De Almeida Jr. A Almeida Jr. Tese de doutorado. São Paulo: ECA/USP, 1996, p.46. ${ }^{159}$ Ibidem, p.48.
} 
Depois da exposição na Casa das Arcadas, onde Mário de Andrade veria as pinturas de Adami, o artista fez algumas outras exposições em São Paulo e no Rio e logo em 1929 viaja novamente para a Europa, voltando ao Brasil no início de 1932. 
V.b. - As sociedades de artistas e Salões de arte.

Hugo Adami não ficou no país para ver de perto a derrocada do império cafeeiro, devido à crise de 1929. O preço do café no mercado internacional havia desabado e, com ele despencou também o valor total das exportações e o governo. Antes que o último pudesse reagir à crise, foi derrubado pelo golpe de estado de 1930. Terminava assim a República Velha e a primeira fase do Modernismo no Brasil.

Do Modernismo, o Brasil intelectual caminhava agora para a "Modernidade", que se caracterizava por uma busca generalizada de interação da arte com a imediata realidade física, humana e social do país. ${ }^{160}$ O próprio Mário de Andrade criticaria o individualismo elitista do Primeiro Modernismo, reivindicando uma arte que se comprometesse mais com o ritmo social e à realidade brasileira. ${ }^{161}$

Essa nova situação coincide com a emergência de artistas provenientes de estratos sociais de menor renda (grupo Santa Helena e a Família Artística Paulista), que, por sinal, não tiveram a mesma formação dos primeiros modernistas. ${ }^{162}$

Esse fato evidencia a importância de artistas com forte embasamento teórico e prático como Paulo Rossi Osir, Vittorio Gobbis e Hugo Adami nos anos futuros da década de trinta. O envolvimento desses artistas com aqueles da nova leva, proporcionará o enriquecimento do leque de informações dos últimos, guiando-os fortemente à valorização dos elementos do Novecento Italiano e ao comprometimento social.

Logo no segundo ano da década de trinta, o governo sofreria com a chamada revolução de 1932, que foi a maior oposição política ao governo de Getúlio Vargas, ocorrida em São

\footnotetext{
${ }^{160}$ ZANINI, Walter. História Geral da Arte no Brasil. São Paulo: Instituto Walter M. Sales, 1983, p.568.

161 AMARAL, Aracy. Da feijoada ao xburguer.São Paulo: Nobel, 1987, p.91.

${ }^{162}$ LOURENÇO, Maria Cecília F. Operários da Modernidade. São Paulo: Hucitec/EDUSP, 1995, p.17.
} 
Paulo. Hugo Adami já se encontrava no Brasil naquela época e se filiava ao grupo de artistas fundadores da Sociedade Pró Arte Moderna, a SPAM.

Os grupos exclusivos, antes presentes nos salões de D. Olívia Guedes Penteado, Tarsila, Paulo Prado, ou na casa de Mário de Andrade, reuniram-se sob a égide da SPAM, organizando salões e bailes de carnaval. A elite cultural paulista passava então a freqüentar locais fora de suas casas, em sociedades mais ou menos abertas, o que caracterizava certa redução do "elitismo modernista" criticado por Mário de Andrade. ${ }^{163}$

A SPAM planejava promover exposições, concertos, conferências, reuniões literárias, festas e instalar uma sede social, com salões grandes para exposições, ateliers e sala de leitura. E mesmo tendo durado tão pouco tempo, cerca de um ano e meio, a SPAM cumpriu quase todas as suas metas.

Em janeiro do ano seguinte, 1933, a SPAM já iniciara suas atividades, mas precisava angariar fundos para continuar seu projeto. Assim, organizou um baile carnavalesco em fevereiro daquele ano, no Salão do Trocadero, em São Paulo.

O baile denominou-se "Carnaval na Cidade de SPAM", sob projeto e direção de Lasar Segall. O salão foi transformado numa autêntica cidade, como relata Paulo Mendes de Almeida, com cadeia, praça pública e monumentos. ${ }^{164}$ Algumas centenas de metros quadrados foram pintados, tendo tomado parte da decoração, além de Segall, Gobbis, Rossi Osir, Anita Malfatti, Hugo Adami, entre outros. Adami ficou encarregado de uma parede:

(...) eu me lembro que meu tema foi até uma cafetina enorme, diante dessas portas tradicionais de bordéis daqui de São Paulo, em que há uma persiana e há lá dentro uma mulher de seios de fora, mais ou menos assim. Este foi o tema que eu pintei dentro da Cidade. (...) ${ }^{165}$

Com o sucesso financeiro esperado, a Sociedade pôde realizar a Primeira Exposição de Arte Moderna da SPAM, da qual Adami participou. A exposição foi aberta ao público em 28

\footnotetext{
163 ALMEIDA, Paulo Mendes de. De Anita ao Museu. São Paulo: Perspectiva, 1983, p.92.

${ }^{164}$ Ibidem, p.89.

165 Entrevista concedida por Hugo Adami ao artista Antônio Hélio Cabral no Museu Lasar Segall, São Paulo, março de 1976, fita d, p.40.
} 
de abril de 1933 e contou com a presença de grandes pintores e escultores da época, tanto brasileiras quanto estrangeiras, pertencentes a coleções particulares de São Paulo. ${ }^{166}$

Alguns meses mais tarde, a SPAM inaugurava sua sede e, em fins de 1933, realizou ali sua Segunda Exposição de Arte Moderna. Desta vez apresentou além dos que participaram na exposição anterior, artistas radicados no Rio: Portinari, Di Cavalcanti e Teruz.

Mas logo viriam novas dificuldades financeiras e a SPAM organizaria outro baile de carnaval, do qual Hugo Adami também participaria. Desta vez o baile intitulou-se "Expedição às Matas Virgens da Spamolândia”. Adami contou ter auxiliado na elaboração de máscaras que seriam penduradas nas paredes do salão. ${ }^{167}$ Logo após esse baile, a SPAM seria fechada.

Além da SPAM, surgiu na mesma época, em São Paulo, outra sociedade de artistas, o Clube de Artistas Modernos, o CAM, liderado por Flávio de Carvalho - no qual a participação de Adami foi mais evidente.

Inaugurado um dia depois da SPAM, em 1932, o CAM durou pouco - apenas até 1933 - e apresentava algumas diferenças da outra agremiação. O CAM não era patrocinado pela burguesia paulistana, mas formado por artistas geralmente de classe média e de orientação esquerdista. ${ }^{168}$ Mas essas diferenças não impediriam que houvesse um intercâmbio de artistas entre ambas associações. Hugo Adami é um bom exemplo disso, já que participou das duas, além de outras várias manifestações culturais da época.

Por volta de 1933, Flávio de Carvalho decidiu instalar no andar térreo do prédio em que se localizava o CAM, o seu Teatro da Experiência. O local era um armazém de

\footnotetext{
${ }^{166}$ Era uma das raras vezes que o público da cidade via pessoalmente trabalhos de artistas como Picasso, Leger, Lipchitz ou Brancusi. Entre os demais artistas estrangeiros estavam Lhote, De Chirico, Delaunay, Dufy e Le Corbusier. Dos artistas nacionais, marcaram presença: Anita Malfatti, Antônio Gomide, Brecheret, Hugo Adami, Rossi Osir, Segall, Tarsila e Gobbis. ALMEIDA, Paulo Mendes de. De Anita ao Museu. São Paulo: Perspectiva, 1983, p.95.

${ }^{167}$ Entrevista concedida por Hugo Adami a Maria Cecília Kunigk e à autora, São Paulo, outubro de 1997.

168 Por essa razão, o CAM apresentava ao público, conferências de tom mais político, como a de Mário Pedrosa, “Teoria Marxista sobre a evolução da arte" e a de Caio Prado Jr., a propósito de sua viagem à Rússia. ZÍLIO, Carlos. A querela do Brasil. Rio de Janeiro: FUNARTE, 1982, p.59.
} 
proporções modestas, onde foi construído um palco e se alinharam cadeiras em número restrito, devido à proporção do lugar.

Ali foi encenado "O bailado do deus morto", peça falada, cantada e dançada.

O enredo envolvia uma escala de alguns milhões de anos e mostrava as emoções dos homens para com seu deus. O primeiro ato tratava-se da origem animal da divindade, o aspecto e a emotividade do monstro mitológico e as razões que levaram a mulher inferior a transformalo num objeto de dimensões infinitas. Mostrava a vida do deus pastando entre as feras do mato e os laços afetivos que mantinha com elas. Era um deus peludo, de cabelo ondulado e longo, como o da mulher que praticou a grande traição. A traição de sangue por matar seus amigos, as feras, abandonando seus companheiros de pasto pelo amor de uma mulher inferior, um ser de uma outra espécie.

No segundo ato, a mulher inferior explica ao mundo porque ela seduziu o monstro mitológico e pacato, entre os animais e colocá-lo como deus entre os homens. Fica claro que por inveja de sua superioridade. Entre um coro de mugido de vacas, os homens do mundo imploram em vão, um deus calado e desaparecido. Perplexos, eles decidem controlar seus destinos, marcam e especificam o fim do deus e o modo de usar seus resíduos no novo mundo. ${ }^{169}$ Hugo Adami disse ter aceito participar do espetáculo (seu personagem era "lamentador"), devido ao fato de reconhecer nele, um teatro avançado para a época, com idéias semelhantes ao que acabara de ver na Europa. Assim descreveu sua impressão da peça:

(...) Nós tínhamos então essa bestialidade, e nós manifestávamos, uma dança, realmente, eu não sei onde é que ia buscar coreografia para isso, era de uma bestialidade, de uma agressividade, com todos aqueles negros

${ }^{169}$ ALMEIDA, Paulo Mendes de. De Anita ao Museu. São Paulo: Perspectiva, 1983, p.82. 
dançando, e eles dentro do ritmo deles mesmos, macumba e não sei quê, africanos, aquilo tudo, coisa fabulosa. E eu envolvido com aquilo tudo, sabe, mas não durou muito, logo em seguida a polícia apareceu lá um dia e, com metralhadora, acabou, fechou o negócio, a peça, fechou inclusive aquela coisa toda. (...) $)^{170}$

Como relata Adami, infelizmente durou pouco. Apenas três apresentações, pois o teatro foi fechado pela polícia e uma guarda especial de quinze homens, armada de carabina e revólver, permaneceu postada durante meses para isolar o público da manifestação de arte. Era esse o fim do Teatro da Experiência.

Esse episódio levaria brevemente ao fechamento do CAM. Numa época de ditadura de direita, o CAM, de tendência esquerdista, não deveria ser mesmo bem visto pelo poder, e, como afirma Carlos Zílio, o Teatro da Experiência foi apenas um pretexto para fechar o clube. $\mathrm{O}$ único crime da peça, afirma o autor, era ser moderna. ${ }^{171}$

A peça possuía tendência sensivelmente expressionista, mesclada a certos elementos da tragédia clássica. O cenário era simbólico e sucinto, fundo negro e uma pira, isolada no meio do palco. Os atores diziam o papel em tom declamatório, dirigindo-se à platéia e fazendo uso às vezes, de palavrões. Havia ainda o sentido plástico na movimentação dos personagens e em suas atitudes. Usavam máscaras de alumínio e uma túnica branca. Em suma, afirma Paulo Mendes, um teatro avançado para a época. ${ }^{172}$

Adami mencionou outro espetáculo que iriam montar, não fosse o fechamento do CAM. A peça era "A ceia dos cardeais" de Júlio Dantas. Contou que iriam modificar o texto, dandolhe inflexões marotas, cheias de intenções. Adami contou que num certo trecho da peça, deveria perguntar sobre as "fugas" do personagem Larandi. Daria duplo sentido à

\footnotetext{
${ }^{170}$ Entrevista concedida por Hugo Adami ao artista Antônio Hélio Cabral no Museu Lasar Segall, São Paulo, março de 1976, fita a, p.16.

${ }^{171}$ ZÍLIO, Carlos. A querela do Brasil. Rio de Janeiro: FUNART, 1982, p.59.

${ }^{172}$ ALMEIDA, Paulo Mendes de. De Anita ao Museu. São Paulo: Perspectiva, 1983, p.82.
} 
palavra "fugas", que poderia se referir às relações extra-conjugais ou às composições musicais do personagem. ${ }^{173}$

Tanto a SPAM, quanto o CAM, começaram a organizar exposições de artistas modernos, consolidando assim, a necessidade de haver um espaço para eles. Desse modo, vindo na seqüência de exposições periódicas da época, fundou-se em 1934, o salão oficial da Sociedade Paulista de Belas Artes. É interessante lembrar um pouco da trajetória dos Salões modernistas em São Paulo, para se verificar a modesta, mas relevante participação de Adami para a consolidação do Modernismo em São Paulo.

Naquele Salão, há pouco citado, apresentavam-se artistas modernos e conservadores. Entre esses últimos, encontravam-se Pedro Alexandrino, Oscar Pereira da Silva, Lucílio de Albuquerque e Antônio Rocco. Já entre os modernos estavam Anita Malfatti, Tarsila, Hugo Adami, Gobbis, Rossi Osir, Volpi, Bonadei e Mário Zanini. ${ }^{174}$

O primeiro Salão Paulista destacou-se pela qualidade das obras modernas expostas e também pelo reaparecimento das rixas entre modernos e conservadores.

O segundo Salão ofereceu o Prêmio Prefeitura, por iniciativa da gestão de Fábio Prado, tendo como exigência que a obra apresentasse temática paulista, o que era uma contribuição ao que Mário de Andrade havia chamado de "carência de universalidade no Modernismo de São Paulo. ${ }^{175}$ Outro prêmio a ser destacado foi o Prêmio Inteligência, destinado à obra de maior cunho nacionalista, conquistado por um artista conservador.

Os modernos então procuraram reverter a situação no quarto salão em 1936. A comissão de seleção estava formada por Gastão Worms, Rocco e Ernani Dias em pintura, mas

\footnotetext{
${ }^{173}$ Entrevista concedida por Hugo Adami ao artista Antônio Hélio Cabral no Museu Lasar Segall, São Paulo, março de 1976, fita a, p.17.

174 ZANINI, Walter. Arte no Brasil nas Décadas de 30 e 40 São Paulo: Instituto Moreira Sales, 1991, p.28.

175 ANDRADE, Mário de. Entrevistas e depoimentos. LOPES, Telê P. A. (org.). In LOURENÇO, Maria Cecília

F. Operários da Modernidade. São Paulo: Hucitec/EDUSP, 1995, p.116.
} 
às vésperas da abertura, pediram demissão, alegando pressão e descontentamento. Nelson Nóbrega recebeu então, delegação da comissão organizadora e convoca Quirino da Silva, Franco Cenni e Hugo Adami, fortalecendo assim, o número de não-conservadores.

Selecionaram apenas 40 artistas e uma ou duas obras exibidas de cada um, o que representou uma redução. Ficaram excluídos pintores como Pedro Alexandrino e Oscar Pereira da Silva, o que fez com que os acadêmicos se sentissem diretamente atingidos. ${ }^{176}$

Hugo Adami conta que Nélson Nóbrega o havia procurado e lhe pedido para realizar o Salão junto com os demais. Adami disse que desejava fazer muitas inovações. Queria dar outro sentido ao sistema de julgamento dos trabalhos:

(...) eu achava que como estava funcionando, estava sujeito ao pintor não julgar através da obra e sim através da capacidade de dialética do pintor, porque muitos têm lábia, outros têm menos. E então, pela ausência de capacidade de defender ou atacar, as vezes entram quadros que não deveriam estar lá, uma incapacidade, as vezes até acontece com um bom pintor, ele é excelente pintor, mas não tem capacidade, é um péssimo advogado, não sabe argumentar. Então, eu achei que era interessante, instituindo naquela ocasião, que o quadro tivesse um número, não mais o nome, que o artista se colocasse um distante de outro, e o contínuo, dava o número do quadro, número 23, olhávamos o quadro, analisávamos cada um se depois na lista, nós dávamos sim ou não, para não haver condições do sujeito mais hábil influir sobre o colega que tivesse menos qualidades de dialética. Isso foi feito e deu resultado fabuloso, porque não houve polêmica, não houve briga. (... $)^{177}$

Nesse trecho, fica clara a intenção de Adami de trazer ao Salão uma postura mais democrática, já que, dispensando os discursos e a proteção de muitos professores que desejavam ter seus alunos ali, ficavam selecionados os quadros que realmente tivessem boas qualidades. Desta feita, por ser o júri composto por partidários do Modernismo, os artistas modernos tiveram melhor chance. Essa situação iria mudar novamente no quinto Salão, em

\footnotetext{
${ }^{176}$ Ibidem, p.118.

177 Entrevista concedida por Hugo Adami ao artista Antônio Hélio Cabral no Museu Lasar Segall, São Paulo, março de 1976, fita c, p.9.
} 
1938, pois na comissão julgadora, Mário de Andrade era o único de tendência moderna, sendo os outros, Lopez de Leão, José Marques Campão e João Del Nero, mais conservadores.

Com os empecilhos causados pelos conservadores no SPBA, os artistas modernos partiram para a criação de associações próprias, resolvendo auto-patrocinar suas exposições, surgindo assim o salão de Maio e a Família Artística Paulista, da qual passou a fazer parte o Grupo Santa Helena. ${ }^{178}$

Em 1937 surgiria o Salão de Maio, cujas três edições de 1937, 1938 e 1939, foram relevantes para a aproximação e aceitação da arte moderna pelo público em geral. Os modernistas podiam já sentir, apesar das batalhas seguintes, que já haviam adquirido um espaço permanente na sociedade paulistana da época. ${ }^{179}$

Paralelamente ao Salão de Maio, em 1937, surgia também a Família Artística Paulista, a FAP, da qual Adami participou na primeira Exposição, no Hotel Esplanada. Expôs com os santelenistas, Volpi, Rebolo, Zanini e Rossi Osir.

Hugo Adami aproximou-se da FAP por ver em seus artistas certos interesses comuns: o senso de equilíbrio, o respeito pelos conhecimentos técnicos e a crença no métier como elemento indispensável para a realização da obra de arte. A FAP diferenciava-se por essa orientação menos "revolucionária", do Salão de Maio, mais ousado e vanguardista. A Família queria estabelecer um equilíbrio, retomar o fio da tradição em arte, prevenindo e prevenindo-se contra os "desvarios" cometidos em nome da expressão, como afirma Paulo Mendes de Almeida. ${ }^{180}$

A Família teria o apoio crítico de Mário de Andrade em seu artigo "Esta Paulista Família", pois seus ideais vinham ao encontro das tendências de Retorno à Ordem que o crítico adotara. Esse grupo de artistas, Rebolo, Volpi, Penacchi e Humberto Rosa, logo entrou

\footnotetext{
${ }^{178}$ LOURENÇO, Maria Cecília F. Operários da Modernidade. São Paulo: Hucitec/EDUSP, 1995, p.116.

${ }^{179}$ Hugo Adami expôs no primeiro e segundo Salões de Maio.

${ }^{180}$ ALMEIDA, Paulo Mendes de. De Anita ao Museu. São Paulo: Perspectiva, 1983, p.108.
} 
em contato com Gobbis, Rossi Osir e Hugo Adami, três artistas de consolidada formação européia, que muito contribuíram para a formação dos artistas do grupo.

A participação daqueles três artistas, todos com vivência na Itália, no ambiente paulista - capazes de conversar sobre pintura, diferenciar pinceladas de um Rafael e Ticiano, como exemplifica Mário de Andrade - foi de enorme auxílio para a educação em artes dos artistas do grupo da FAP, vindos de um meio desprovido de recursos financeiros para os estudos.

Muitos deles eram pintores de parede, que nas horas vagas enfrentavam o cavalete. Mesmo não tendo alcançado a projeção de Gobbis e Rossi Osir, a contribuição de Adami para o panorama artístico de São Paulo da época não deve ser desmerecida. Adami relatou que saía para pintar com Penacchi, Bonadei, Clovis Graciano e Gobbis, chegando a ministrar certa vez, uma palestra sobre arte italiana para o grupo Santa Helena. ${ }^{181}$

A segunda exposição da FAP ocorreu em 1939, da qual participaram Portinari, os integrantes do Santa Helena, Hugo Adami, Ernesto De Fiori, entre outros. Nesse ano Adami não estava mais no Brasil, (deixou contudo, trabalhos para setrem expostos) havia partido para a Europa em 1937 e ressentia não ter ficado aqui para estar junto dos seus amigos Santelenistas. ${ }^{182}$

Mas Adami não serviu de orientador somente para o pessoal da FAP e do Santa Helena, Já por volta de 1933, Adami transitou entre São Paulo e Rio de Janeiro, travando debates com Teruz, Portinari, entre outros. ${ }^{183}$

Devido à ebulição política da época, muitos intelectuais e artistas sentiram a necessidade de trazer para a arte e a cultura erudita, aspectos da realidade social. Como muitos

\footnotetext{
${ }^{181}$ Entrevista concedida por Hugo Adami ao artista Antônio Hélio Cabral no Museu Lasar Segall, São Paulo, março de 1976, fita a, p.57.

182 Ibidem.

${ }^{183}$ Sobre este assunto, consultar a Introdução desta dissertação.
} 
outros artistas, Adami foi contagiado por essa preocupação. ${ }^{184}$ Nessa época, o artista já conhecia Portinari e afirmou ter sido um pouco responsável pelo interesse do artista de Brodósqui em questões sociais. ${ }^{185}$

Em 1942 e 43, já definitivamente no Brasil expôs no Salão de Belas Artes do Rio de Janeiro e em 1944, foi membro da comissão organizadora da divisão moderna desse Salão.

Adami criticou alguns aspectos daquele Salão no que dizia respeito ao julgamento de alguns artistas, como Portinari, Volpi e Clóvis Graciano. Achava que eles já haviam adquirido maturidade e projeção suficientes para não precisarem ser julgados. Artistas como eles deveriam ser convidados e os julgados deveriam ser os novatos.

Num outro salão, realizado na Escola de Belas Artes do Rio, Adami modificou o julgamento de obras ao convocar novamente o júri, após feita a seleção. ${ }^{186} \mathrm{O}$ pintor tomou essa atitude por achar que haviam julgado os trabalhos precipitadamente no dia anterior:

(...) Então chamei todos de novo, falei, eu tenho a impressão que nós estamos cometendo injustiça. Há valores lá em baixo no porão e deve ter também, dos que nós escolhemos, alguns que não tenham condições... e foi feito, quebramos aquele tabu, nos reunimos de novo, então entraram uma porção dos que estavam no porão e saíram muitos daqueles já escolhidos. E assim é que entrou Renee Lefebvre, Mário Pedrosa. (...) ${ }^{187}$

\footnotetext{
${ }^{184}$ Assim, como foi mencionado, se envolveu com o filme de Humberto Mauro, "Favela dos meus amores", realizado no Rio de Janeiro em 1933. Humberto Mauro lhe havia solicitado que elaborasse os cenários, idéia que mais tarde, foi deixada de lado, pois o filme se desenvolvia melhor em cenas ao ar livre. Mesmo assim, Adami não se afastou da produção e da equipe, que passou a viver com o pessoal da favela. Foi assim que pintou uma paisagem com barracos, "Favela dos meus amores", o retrato do moleque 19 adormecido, (figurante do filme).Sobre essa obra - que levou o título de "Fugitivo" - o pintor contou certa vez, vir lhe procurar o moleque, para pedir abrigo, pois estava fugindo da polícia. Adami o acolheu em sua casa e o pintou repousando em seu quintal. BARATA, Mário. Dados histórico-críticos sobre Hugo Adami. São Paulo: Instituto Cultural Itaú, centro de informática e cultura, 1991, p.23.

${ }^{185}$ Em 1935, Adami participou da exposição coletiva de artes sociais no Clube de Cultura Moderna no Rio de Janeiro, com Portinari, Di Cavalcanti, Teruz e Guignard, entre outros. Aníbal Machado proferiu uma conferência sobre a exposição e afirmou ser ela, mais uma possibilidade de encurtar o distanciamento entre a arte e a coletividade.Ibidem, p.33.

${ }^{186}$ Entrevista concedida por Hugo Adami ao artista Antônio Hélio Cabral no Museu Lasar Segall, São Paulo, março de 1976, fita b, p.10.

${ }^{187}$ Ibidem, p. 12.
} 
Adami disse se preocupar com pintores cuja linguagem era muito "diferente", pois tinha medo de não compreender um novo trabalho e assim, cometer uma injustiça. ${ }^{188}$

Aquela preocupação de Adami em não ser “injusto”, mostrava que o artista já começava a questionar seus pressupostos realistas e o desenvolvimento que a pintura seguia no Brasil.

${ }^{188}$ Ibidem, p.13. 


\section{CONCLUSÃO}

Talvez por ter se afastado durante tantos anos da pintura e por ter possuído um caráter individualista, Adami tenha tido sua contribuição para o Modernismo paulistano, esquecida ou negligenciada.

Conforme visto, o pintor se envolveu em várias manifestações artísticas da época, tanto no Brasil quanto na Itália. Contudo, não se deixava tomar totalmente por uma ou outra causa. Envolvia-se, mas mantendo sempre certo distanciamento, certo limite, ou seja, para Adami era imprescindível conservar sua individualidade, a liberdade de seguir seus próprios anseios.

Ele dizia ter dentro de si uma constante "inquietação"; fato que o impulsionava a buscar vários contatos, com pessoas e linguagens artísticas. Por isso foi um artista tão plural, sem que isso significasse superficialidade ou o que chamou de "anulação da linguagem pessoal". Em sua pintura, estabeleceu diálogos com as obras de Morandi, De Chirico e Cézanne, principalmente. Herdando do primeiro uma preocupação tonal para resolver a composição, do segundo, a metafísica, desenvolvendo em suas pinturas, uma maneira peculiar de compreendêla e do último, a geometrização das paisagens, sem, contudo, preocupar-se em revolucionar a noção de espaço na tela.

Adami sempre foi fiel aos seus princípios realistas, assimilando facilmente as teorias novecentistas. O artista não iria questionar o Realismo até deparar-se com a pintura nãofigurativa,189 que floresceria no Brasil, no final da década de quarenta. Porém, no princípio daquela década, pára sua produção por estar descontente com o que chamou de "a invasão cubista", ocorrida entre os artistas da época. Adami foi um forte opositor à "contaminação"

\footnotetext{
${ }^{189}$ Adami não foi o único a preocupar-se com os rumos que a pintura tomava, no final da década de quarenta, aqui no Brasil. Tarsila do Amaral repensou sua obra, desenvolvendo o que foi chamado de Neo-pau-Brasil, na década de sessenta. Não abandonou, contudo, o Realismo. AMARAL, Aracy. Tarsila: sua obra, seu tempo. São Paulo: Perspectiva, 1975, p.349.
} 
cubista sofrida por seus colegas que, segundo ele, deixavam suas linguagens próprias serem anuladas pelas resoluções de Picasso. Mas até então, o artista não punha em cheque seus preceitos realistas, pelo contrário, agarrava-se a eles para defender seus colegas dos influxos cubistas.

O conflito de Adami se estabeleceria mais tarde, depois que já havia deixado de pintar, devido à pintura-não figurativa. $\mathrm{O}$ artista confrontou sua formação realista com aquela nova pintura e obteve o silêncio como resposta imediata. ${ }^{190}$ Adami só voltaria a pintar na década de setenta, quando pensou que poderia favorecer-se das impossibilidades físicas causadas pela idade, na busca de uma pintura mais solta, livre de sua "rigidez" realista. Todavia, Adami se enganou ao pensar assim. Sua formação realista era inseparável de seu olhar e assim o artista conseguiu alguma liberdade no tratamento da cor, mas não na concepção da forma.

Adami não conseguiu acompanhar a evolução das artes plásticas no Brasil, mesmo se permitindo certas modificações no pensar a cor.

Mesmo assim, sua contribuição para o desenvolvimento do Modernismo em São Paulo não deve ser negligenciada, principalmente no que diz respeito à sua pintura recém chegada da Itália, no final da década de vinte, que auxiliou Mário de Andrade a compreender visualmente as teorias de Retorno à Ordem de Jeanneret e Ozenfant.

\footnotetext{
${ }^{190}$ Adami parece ter sido o único pintor da geração modernista a interromper sua produção pictórica devido às questões impostas pela pintura não-figurativa. Di Cavalcanti, em uma conferência, realizada no Museu de Arte de São Paulo, em 1948, posiciona-se radicalmente contra a pintura não-figurativa, dizendo ser esta, individualista e alienada. Di Cavalcanti acreditava e propunha para as artes plásticas no Brasil, o Realismo Social, e dentro desse Realismo, continuou a desenvolver sua pintura. Portinari dizia-se igualmente contra a pintura não-figurativa embora, nos anos cinquienta, nas palavras do crítico brasileiro Mário Pedrosa, o artista tenha cometido um "deslize" ao sucumbir à tentação de se dispor do "Abstracionismo Geométrico" para elaborar seu painel de pastilhas no Edifício Califórnia, na rua Barão de Itapetininga, em São Paulo. Pedrosa chamou o painel de "grotesco Mondrian em vidrotil", para ressaltar a empreitada mal sucedida de Portinari. Segundo Pedrosa, as dúvidas de Portinari quanto ao que se chamou de Abstrato e seu confronto com o Realismo, fizeram com que o artista não resolvesse bem a composição daquele painel. Lasar Segall, por sua vez, não aderiu igualmente à pintura não-figurativa da época, mantendo-se fiel ao seu Realismo Expressionista. AMARAL, Aracy. Arte para quê? São Paulo: Nobel, 1984, pp.233-242.
} 
Foi a partir do contato com a produção de Adami e da reflexão que esta lhe possibilitou que Mário de Andrade pôde direcionar seu projeto modernista para São Paulo, nos anos trinta. Tamanho foi o interesse de Andrade pelas pinturas de Adami, expostas em São Paulo, em 1928, que o crítico lhes dedicou um longo ensaio no Diário Nacional e adquiriu o quadro "Cebolas".

Mário de Andrade reconheceu nas pinturas de Adami, guiadas pelos preceitos novecentistas, os elementos cruciais de sua teoria modernista: a atualização da linguagem plástica nacional, por meio do Realismo, não passadista de Adami, e a possibilidade oferecida por este Realismo para a criação de uma identidade brasileira, ou seja, uma arte que mostrasse traços típicos da realidade física e humana do país. 


\section{ANEXO 1 \\ INFORMAÇÕES BIOGRÁFICAS}

Pílade Francisco Hugo Adami nasceu em 8 de dezembro, no bairro do Brás na cidade de São Paulo, em 1899. Contudo, foi registrado em 2 de janeiro de 1900. Seus pais, Leoneto e Leoneta Adami vieram da Itália. Seu pai foi um próspero industrial no Brasil, (Tecelagem Brasil) e músico nas horas vagas. Aos cinco anos de idade, sua mãe o presenteou com um tambor e uma caixa de tintas e Hugo Adami deu preferência à caixa de tintas. Durante sua infância lia livros de literatura infantil e clássicos, assistia ópera e peças teatrais, sempre orientado por sua mãe.

Aos 11 anos de idade, pintava lenços com a lenda de Verônica - retrato de Cristo - e os vendia por encomenda a uma loja de artigos religiosos, na Rua Direita. Com o dinheiro dessas vendas, presenteava meninas com artigos de beleza. Neste mesmo ano, já havia começado a estudar pintura na Escola Profissional Masculina do Brás, tendo como professor, Giuseppe Barchitta. Assim que concluiu seus estudos na Escola, em 1913, Adami continuou a estudar pintura no Liceu de Artes e Ofícios, sendo, aluno de Alfredo Norfini.

Com 13 anos de idade, pintou o retrato do almirante Pedro Alexandrino Alencar, então Ministro da Marinha. O retrato foi ofertado ao Ministro pelas senhoras da sociedade paulistana, quando aquela autoridade visitou São Paulo pela primeira vez. O Ministro registrou o fato no Cartório Firmo e presenteou Adami com um relógio Girard Perregoux, que o artista paulista doou para uma jovem, aos 18 anos.

Mas não era somente a pintura que o interessava na juventude. Em 1914 estudava canto e artes cênicas com o tenor italiano De Cimoni, em São Paulo. No ano seguinte, formou com um grupo de jovens, o Grêmio Leopoldo Fróes. $\mathrm{Na}$ apresentação da primeira peça, realizada no Grêmio Almeida Garret, homenageou o próprio Leopoldo Fróes. Entusiasmado com o 
jovem ator, Fróes convidou-o para trabalhar com sua Companhia no Rio de Janeiro, o que ocorreria algum tempo depois.

Por vota de 1916, Adami ingressou no curso de pintura de J. Fisher Elpons, em São Paulo, tendo como colegas Di Cavalcanti e Tarsila do Amaral. Elpons e Adami acabam tornando-se admiradores recíprocos. Nessa época, Adami fazia retratos para a sociedade paulistana e para os mestres da Faculdade de Direito do Largo São Francisco, por encomenda do fotógrafo Hermann Storz. ${ }^{191}$ Passou a pintar paisagens nos arredores de São Paulo e a relacionar-se cada vez mais com os futuros artistas modernistas de São Paulo, fazendo nesse tempo o retrato de Menotti del Picchia.

Finalmente, integra-se ao elenco da Companhia de Teatro Leopoldo Fróes no Rio de Janeiro. Isso aconteceu por volta de 1918. Porém, mesmo dedicando-se ao teatro, Adami continuou a pintar paisagens por lá e fez de seu camarim um atelier. Mas sua primeira exposição aconteceu no Salão Nacional de Belas Artes no Rio de Janeiro, em 1921. Recebeu na ocasião, uma medalha de prata. Depois disso, convencido de seu talento para a pintura, voltou a morar em São Paulo e a relacionar-se novamente com os intelectuais e artistas simpatizantes do Modernismo. Freqüentava muitas reuniões do grupo, sem, contudo, chegar a participar da exposição de 22. Nesse ano, pinta o retrato de Mário de Andrade e em seguida, pela primeira vez, viaja para a Europa.

Chegando lá, estabeleceu-se em Florença, com um atelier situado na Praça Donatello. Logo na chegada conhece o poeta Berto Ricci e os pintores Otoni Rosai e De Chirico, tornandose grande amigo dos três. Provavelmente, o contato com De Chirico e de toda a conjuntura das artes na Itália da época fizeram com que Adami abandonasse a Academia de Belas Artes de Florença para viajar pelo país em busca dos mestres antigos da Renascença.

\footnotetext{
${ }^{191}$ Nem fotografias ou quadros atribuídos a Hugo Adami foram encontrados no acervo da Faculdade de Direito do Largo de São Francisco, da USP, na cidade de São Paulo.
} 
Em 1923 começam as exposições de Adami. Mesmo estando na Europa, participa do Salão da Primavera, no Rio de Janeiro. Em 1924, expõe na Décima Quarta Mostra Internacional de Veneza, com o único auto-retrato que pintou em sua vida. Adami foi o primeiro artista brasileiro a participar daquela mostra. Em 26, expõe em Florença, na Quinta Mostra Regional de Arte; expõe também em Milão, na primeira mostra do Novecento Italiano, no Convegno D' Arte e na corporação Intelectual em Florença. Um ano depois, retorna ao Brasil.

Ao chegar em seu país, Adami fixa-se em são Paulo e participa do almoço Antropofágico que homenageava Piolim. Em 1928, expõe na Galeria das Arcadas, em São Paulo, sua primeira exposição individual, visitada por Mário de Andrade; que iria escrever um longo ensaio sobre ela no jornal Diário Nacional. A segunda individual, aconteceu na Galeria Guatapará, também em são Paulo, no mesmo ano. Antes de retornar novamente à Europa, em 1929, expõe na Escola Nacional de Belas Artes, no Rio de Janeiro.

De volta à Europa, participa de mais exposições: Décima Sétima Mostra Internacional de Veneza de 1930 e Salon Des Tuileries, em Paris, 1932. No ano anterior, havia se casado em Florença, com Maria Paula de Barros Monteiro, brasileira, atriz e professora de dicção dramática.

Depois dessa curta estadia na Europa, de apenas três anos, Adami retorna a São Paulo e participa da fundação da Sociedade Pró Arte Moderna e do Clube dos Artistas Modernos. Em 1933, evolveu-se plenamente com aquelas sociedades. Auxiliou na organização do primeiro baile de carnaval da SPAM e participou de sua primeira exposição coletiva. No CAM, atuou na peça, “O bailado do deus morto" de Flávio de Carvalho e expôs no primeiro Salão Paulista de Belas Artes. Adami era o único ator branco no elenco da peça e talvez tenha sido o primeiro ator brasileiro a dizer um palavrão em cena. Expôs novamente na Galeria Guatapará, em 1933 (individual) e então, no ano seguinte, se mudou para o Rio de Janeiro, para participar da produção do cenário do filme, "Favela dos meus Amores" de Humberto 
Mauro. O diretor achou que seria mais significativo para o filme que as cenas fossem rodadas ao ar livre, e assim, restou muito pouco a fazer para Hugo Adami. Todavia o artista paulista não se separou da equipe de filmagem, nem dos moradores da favela.

Pinta o quadro "Fugitivo" e estreita relações com Portinari e Teruz, no Rio. Mas apesar de estar vivendo na antiga capital federal, auxiliou na decoração do segundo baile de carnaval da SPAM, em 1934. No ano seguinte, mais um ciclo de exposições: expôs no Salão de Belas Artes do Rio de Janeiro; na coletiva “Artes Sociais”, no Clube de Cultura Moderna, na mesma cidade. Participou do III Salão Paulista de Belas Artes, quando recebeu Grande Medalha de Prata e finalmente, expôs na "Só Retratos", exposição anual da Associação de Artistas Brasileiros, no Rio. Nesse ano também participou do almoço em homenagem a Portinari, (por ele ter recebido o prêmio Pittisburg).

Em 1936, participou do IV Salão Paulista de Belas Artes, quando recebeu a Medalha de Ouro. Fez parte do júri de seleção e premiação deste Salão ao lado de Quirino da Silva e Franco Cenni. Fez um desenho de Piolim para uma revista da época. Expôs no I Salão de Maio, no Hotel Esplanada, em São Paulo e pintou o retrato de Graciliano Ramos para ilustrar a revista Academia, número 36. Ilustrou a capa desta mesma revista com um retrato desenhado do escritor francês Romain Rolland, então homenageado pelo seu septuagésimo aniversário. ${ }^{192}$

Separou-se então de sua primeira mulher, Maria Paula. Nesse ano, muda-se para um apartamento na rua Barata Ribeiro, no Rio de Janeiro, onde realizava festas decoradas por Ibrahim Sued período em que, provavelmente conheceu sua segunda mulher, Jovita do Amaral, integrante da sociedade carioca.

${ }^{192}$ Foi apenas encontrada uma fotocópia da capa da revista, onde não constavam data e número. 
No ano de 1937, participou da primeira exposição da Família Artística Paulista, ao lado de Volpi, Bonadei, Graciano e Rossi Osir, entre outros. Vivia nessa época constantemente com os artistas da FAP e começava também a dedicar-se a apostas de cavalo. Nesse mesmo ano, viajou novamente para a Europa, levando consigo sua segunda mulher, Jovita do Amaral, que na época, já o sustentava.

Antes de retornar ao Brasil, em 1940, Adami participou do II Salão de Maio e fez outra individual na Galeria Guatapará, em São Paulo. Fez também uma exposição individual no Palace Hotel, no Rio de Janeiro, em 1939.

Já em 1940, em Paris com Di Cavalcanti, Noêmia Mourão e Jovita do Amaral, Adami produziu um programa radiofônico anti-hitlerista que, em Paris, transmitia boletins de guerra em língua portuguesa para o Brasil e Portugal, pontualmente à meia noite, de uma rádio em Paris. A Segunda Guerra Mundial já havia começado e os alemães já tinham tomado a capital francesa. Todavia, Adami e seus companheiros, que tinham combinado permanecer para conduzir o programa, se separaram. Adami, de repente, viu-se sozinho com a esposa e a situação começava a ficar insustentável. Assim, depois de muita espera e angústia, ele e Jô conseguiram voltar ao Brasil num navio chamado Massília, saído de La Rochelle. Trouxe com ele os quadros que havia produzido na época, não retornando mais à Europa em toda sua vida.

De volta à sua terra natal, Adami participou então, do VII Salão Paulista de Belas Artes e ainda em 1940, executou com Gobbis a decoração de um salão de carnaval no Hotel Copacabana Palace, no Rio de Janeiro. Em 1941, decorou o mesmo salão de carnaval no Copacabana Palace, mas desta vez, com Santa Rosa. Participou do debate "Arte Moderna", no Salão de Exposições da Associação de Artistas Brasileiros no Palace Hotel, Rio de Janeiro, juntamente com Santa Rosa, Aníbal Machado, Antônio Bento e Celso Kelly. 
Entre 1942 e 1944 participou do XLVIII Salão Nacional de belas Artes do Rio de Janeiro, quando recebeu Grande Medalha de Prata, expôs no XLIX Salão Nacional de Belas Artes do Rio de Janeiro, quando recebeu Grande Medalha de Ouro e fez parte da Comissão Organizadora da divisão moderna do Salão Nacional de Belas Artes, que deu o prêmio Viagem ao Exterior a Milton Dacosta. Em 1945, por contrato com a Prefeitura do Rio de Janeiro, organizou com Luiz Peixoto, a decoração do carnaval de rua da avenida Rio Branco. Por volta desse ano, interrompeu suas atividades pictóricas e dedica-se novamente a apostar em corridas de cavalo. Daí então, Adami passa a viver em contato com os integrantes da alta sociedade carioca até separar-se de Jovita na década de sessenta.

Depois da separação, por volta de 1964, passou a residir em São Paulo e a trabalhar como relações públicas na Gigante Pirani do Brás, loja de departamentos de seus primos. Na época em que trabalhou na Pirani, Adami organizou algumas exposições de arte moderna em suas instalações, especificamente no período mais próximo a década de setenta.

Em 1975 voltou decididamente a pintar. Expôs na retrospectiva "SPAM e CAM", no Museu Lasar Segall, em São Paulo; em 1976 expôs em outra retrospectiva no Museu Lasar Segall: “Os Salões” e, em 1980, participou da exposição “Três Pioneiros dos Tempos dos Salões”, no Museu Lasar Segall, quando foram homenageados, Hugo Adami, Joaquim Lopez Figueira e Mick Carnicelli. Em 1982 foi incluído na exposição “Do Modernismo à Bienal”, no Museu de Arte Moderna de são Paulo, (MAM), exposição comemorativa dos 60 anos da Semana de 22; em 1985, participou da exposição “A Outra Geração 80”, no VIII Salão Nacional de Artes Plásticas, no Rio de Janeiro, quando recebeu da comissão organizadora, um diploma, entregue pelo então presidente, José Sarney. No ano seguinte, houve sua Retrospectiva no MAM, em São Paulo. Continuou a pintar até por volta de 1996, quando abandonou definitivamente essa atividade. Faleceu em São Paulo, em 28 de dezembro de 1999, aos 100 anos de idade, vítima de parada respiratória. 


\section{ANEXO 2 \\ SOBRE O LEVANTAMENTO DE OBRAS DE ADAMI}

Para a realização desta pesquisa, foram localizados alguns trabalhos de Hugo Adami, no total de 282 obras, 185 pinturas e 97 desenhos. A maior parte da produção encontrada pertence a colecionadores particulares, sendo raros os museus que possuem obras do artista em suas coleções. O levantamento dessas obras foi dividido entre museus e colecionadores particulares, com o intuito de facilitar a busca às obras de Adami por futuros pesquisadores. Assim, os trabalhos foram organizados segundo as coleções, não obedecendo a outro critério como categoria, (desenho ou pintura), ou gêneros, (natureza-morta, paisagens ou retratos). Dentro de cada coleção, os trabalhos não datados vêm em primeiro lugar, seguidos por outros em ordem cronológica.

A maioria dos trabalhos não é datada, o que dificultou situa-los numa ordem precisa. Felizmente, muitos colecionadores sabiam pelo menos a década em que suas obras foram produzidas, auxiliando a organização cronológica das mesmas.

Este levantamento não abrange toda a produção do artista, pois muitos de seus trabalhos não têm paradeiro conhecido; alguns colecionadores não se interessaram muito em contribuir, e, algumas instituições sequer responderam aos pedidos de informação, como a Fundação Bienal de Veneza.

A maioria dos quadros encontrados estava na cidade de São Paulo, pois não foi encontrada a família de sua ex-mulher, Jovita do Amaral - apesar da ajuda de Mônica Xexeu, do Museu Nacional de Belas Artes do Rio - que deveria possuir muitos quadros do artista.

Não foram incluídas as imagens dos trabalhos de Adami neste levantamento, pois a documentação fotográfica recolhida não possuía características profissionais, servindo apenas como mera referência ao objeto, na hora de seu estudo. 
Embora não sendo completo, este levantamento foi extremamente útil para formar um primeiro conjunto da produção pictórica de Adami, possibilitando sua observação e análise. É de se esperar que, no futuro, este levantamento venha a servir de base para que outros pesquisadores da obra do artista realizem a catalogação definitiva de sua obra. 
ANEXO 3

LEVANTAMENTO PRELIMINAR DA OBRA DE HUGO ADAMI

MUSEUS

ACERVO DO INSTITUTO DE ESTUDOS BRASILEIROS DA UNIVERSIDADE DE SÃO PAULO - IEB, USP.

Título - Retrato de Mário de Andrade, (figura 13, no texto)

Categoria - pintura

Técnica - óleo s/tela

Dimensões - 45,5 x $36 \mathrm{~cm}$

Data -1922

Assinatura - assinado na frente com dedicatória a Mário. Canto inferior direito.

Título - Cebolas, (figura 27, no texto)

Categoria - pintura

Técnica - óleo s/tela

Dimensões -43 x 53,5 cm.

Data - 1926

Assinatura - assinado no verso. Canto inferior direito.

Título - Nu feminino

Categoria - desenho

Técnica - lápis e carvão s/papel

Dimensões - 37,7 x $31 \mathrm{~cm}$ 
Data -1928

Assinatura - assinado na frente em dedicatória a Mário: Ao Mário, do Hugo, São Paulo, 1928. Canto inferior direito. 
MUSEU DE ARTE CONTEMPORÂNEA DA UNIVERSIDADE DE SÃO PAULO MAC, USP

Título - Natureza-Morta

Categoria - desenho

Técnica - nanquim e grafite s/papel

Dimensões - 32,8 x 40,6 cm

Data $-\mathrm{s} / \mathrm{d}$

Assinatura - não assinado

Título - Nu feminino

Categoria - desenho

Técnica - crayon s/papel

Dimensões - 28,2 x 45,3 cm.

Data $-\mathrm{s} / \mathrm{d}$

Assinatura - não assinado

Título - Nu feminino

Categoria - desenho

Técnica - grafite s/papel

Dimensões - 45,3 x $28 \mathrm{~cm}$.

Data $-\mathrm{s} / \mathrm{d}$

Assinatura - não assinado

Título - Nu feminino

Categoria - desenho

Técnica - crayon s/papel

Dimensões - 28,2 x 44,7

Data - s/d 
Assinatura - não assinado

Título - Nu feminino

Categoria - desenho

Técnica - crayon s/papel

Dimensões - 44,5 x 31,3

Data $-\mathrm{s} / \mathrm{d}$

Assinatura - não assinado

Título - Nu feminino

Categoria - desenho

Técnica - pastel seco s/papel

Dimensões - 27,7 x 45,2

Data - s/d

Assinatura - não assinado

Título - Nu feminino

Categoria - desenho

Técnica - crayon s/papel

Dimensões - 45,1 x $28 \mathrm{~cm}$.

Data $-\mathrm{s} / \mathrm{d}$

Assinatura - não assinado

Título - Nu feminino

Categoria - desenho

Técnica - grafite s/papel

Dimensões - 28,2 x 45,3 cm.

Data $-\mathrm{s} / \mathrm{d}$

Assinatura - não assinado 
Título - Paisagem

Categoria - desenho

Técnica - nanquim s/papel

Dimensões - 33 x $41 \mathrm{~cm}$.

Data - s/d

Assinatura - não assinado

Título - Paisagem

Categoria - desenho

Técnica - nanquim e crayon s/papel

Dimensões - 33 x $41 \mathrm{~cm}$.

Data - s/d

Assinatura - não assinado 


\section{MUSEU DE ARTE MODERNA DE SÃO PAULO - MAM}

Título - Positano, (figura 33, no texto)

Categoria - pintura (paisagem)

Técnica - óleo s/tela

Dimensões - 73 x $60 \mathrm{~cm}$.

Data - 1937

Assinatura - assinado no verso. Canto inferior direito. 
MUSEU NACIONAL DE BELAS ARTES DO RIO DE JANEIRO - MNBA

Título - Fugitivo, (figura 39, no texto)

Categoria - pintura (retrato)

Técnica - óleo s/tela

Dimensões - $98 \times 148 \mathrm{~cm}$.

Data -1934

Assinatura - assinado no verso. Canto inferior direito. 


\section{GRUPO UNIVERSITÁRIO FIEO - UNIFIEO}

São Paulo

Título - Paisagem

Categoria - pintura

Técnica - óleo s/tela

Dimensões - 46 x $55 \mathrm{~cm}$.

Data - anos 90.

Assinatura - assinado no verso. Canto inferior direito. 
SOCIARTE,

São Paulo

Título - Paisagem

Categoria - pintura

Técnica - óleo s/tela

Dimensões - 50 x $70 \mathrm{~cm}$.

Data - s/d

Assinatura - assinado na frente e verso. Canto inferior direito. 
COLECIONADORES

\section{COLEÇÃO ADRIANA ADAMI}

São Paulo

Título - Poente

Categoria - pintura (paisagem)

Técnica - óleo s/tela

Dimensões - 56 × $71 \mathrm{~cm}$

Data $-\mathrm{s} / \mathrm{d}$

Assinatura - não assinado

Título - Os morangos

Categoria - pintura (natureza-morta)

Técnica - óleo s/tela

Dimensões - 53 x $64 \mathrm{~cm}$.

Data - anos 20 .

Assinatura - assinado no verso. Canto inferior direito.

Título - As Artes, (figura 24, no texto)

Categoria - pintura (natureza-morta)

Técnica - óleo s/tela

Dimensões -82 x $101 \mathrm{~cm}$.

Data -1925

Assinatura - assinado no verso. Canto inferior direito. 


\section{COLEÇÃO BELLKISS BARIONI}

\section{São Paulo}

Título - Natureza-Morta com Faisão

Categoria - pintura

Técnica - óleo s/tela

Dimensões - 50 x $65 \mathrm{~cm}$.

Data $-\mathrm{s} / \mathrm{d}$

Assinatura - não assinado

Título - A Velha Bretã

Categoria - pintura (retrato)

Técnica - óleo s/ cartão

Dimensões - 52 × $39 \mathrm{~cm}$

Data -1916 - 1918, (c.)

Assinatura - assinado no verso. Canto inferior direito.

Título - Frango, (figura 7, no texto)

Categoria - pintura (natureza-morta)

Técnica - óleo s/tela

Dimensões - 40 × $12 \mathrm{~cm}$

Data - 1916

Assinatura - assinado no verso. Canto inferior direito. Com uma etiqueta: grande medalha de ouro no Salão Paulista de Belas Artes e grande medalha de prata no Salão Nacional de Belas Artes do Rio de Janeiro.

Título - Natureza-Morta com Garrafão

Categoria - pintura

Técnica - óleo s/ madeira 
Dimensões -63 x $51 \mathrm{~cm}$

Data - anos 20.

Assinatura - não assinado

Título - Natureza-Morta com Garrafão.

Categoria - pintura (natureza-morta com 5 pêssegos e garrafa ao centro)

Técnica - óleo s/ madeira

Dimensões -50 x $65 \mathrm{~cm}$.

Data - anos 20.

Assinatura - não assinado

Título - Paisagem Toscana

Categoria - pintura

Técnica - óleo s/tela

Dimensões -29 × $35 \mathrm{~cm}$

Data -1926

Assinatura - assinado no verso. Canto inferior direito.

Título - Paisagem Toscana

Categoria - pintura

Técnica - óleo s/tela

Dimensões - 29 x $35 \mathrm{~cm}$.

Data -1926

Assinatura - assinado no verso. Canto inferior direito.

A colecionadora possui três desenhos de Hugo Adami: um nu feminino, um retrato de Walter Barioni e um Mandarim, mas não lembra onde os guardou. 


\section{COLEÇÃO BETE BARRETO}

\section{São Paulo}

Título - sem título

Categoria - pintura (natureza-morta na praia com abóboras)

Técnica - óleo s/tela

Dimensões -64 x $53 \mathrm{~cm}$

Data $-\mathrm{s} / \mathrm{d}$

Assinatura - assinado na frente e verso. Canto inferior direito.

Título - Paisagem com Abismo

Categoria - pintura

Técnica - óleo s/tela

Dimensões -54 x $73 \mathrm{~cm}$

Data - anos 70 .

Assinatura - assinado na frente e verso. Canto inferior direito.

Título - sem título

Categoria - pintura (paisagem com sol ao fundo e meio pinheiro no campo da frente)

Técnica - óleo s/tela

Dimensões - 54 × $73 \mathrm{~cm}$.

Data - anos 70 .

Assinatura - assinado na frente e no verso. Canto inferior direito. 


\section{COLEÇÃO CLARA ADAMI}

São Paulo

Título - Pai

Categoria -pintura (retrato)

Técnica - óleo s/tela

Dimensões - 77 x $44 \mathrm{~cm}$.

Data $-\mathrm{s} / \mathrm{d}$.

Assinatura - assinado na frente. Canto inferior direito.

Título - O Adeus do Marinheiro

Categoria - pintura (retrato)

Técnica - óleo s/tela

Dimensões - 54 X $65 \mathrm{~cm}$

Data -1930

Assinatura - assinado no verso. Canto inferior direito.

Título - Marinha

Categoria - pintura

Técnica - óleo s/tela

Dimensões - 40 x $50 \mathrm{~cm}$.

Data - 1941

Assinatura - assinado na frente. Canto inferior direito. 


\section{COLEÇÃO CLÁUDIA ADAMI}

São Paulo

Título - O velho

Categoria - pintura

Técnica - óleo s/tela

Dimensões -44 x $58 \mathrm{~cm}$.

Data - 1916

Assinatura - assinado na frente. Canto inferior direito.

Título - Natureza-Morta com faisões

Categoria - pintura

Técnica - óleo s/tela

Dimensões - 100 x $81 \mathrm{~cm}$.

Data - anos 20 .

Assinatura - assinado na frente. Canto inferior direito. 


\section{COLEÇÃO CONSTANTINO IGNÁCIO RIEMMA}

\section{São Paulo}

Título - Represa

Categoria - pintura (paisagem)

Técnica - óleo s/tela

Dimensões - 50 × $60 \mathrm{~cm}$

Data - anos 80 .

Assinatura - assinado na frente. Canto inferior direito. 


\section{COLEÇÃO EDA ADAMI}

\section{São Paulo}

Título - sem título

Categoria - pintura (paisagem com sol, montanha e coqueiro)

Técnica - óleo s/tela

Dimensões -60 x $50 \mathrm{~cm}$

Data $-\mathrm{s} / \mathrm{d}$

Assinatura - assinado no verso. Canto inferior direito.

Título - Casa com Árvore

Categoria - pintura

Técnica - óleo s/tela

Dimensões $-60 \times 50 \mathrm{~cm}$.

Data - anos 70 .

Assinatura - assinado no verso. Canto inferior direito.

Título - sem título

Categoria - pintura (paisagem com pinheiro e árvore de folhagem amarela)

Técnica - óleo s/tela

Dimensões -60 x $50 \mathrm{~cm}$.

Data - anos 70 .

Assinatura - assinado frente e monogramado no verso (H.A.). Canto inferior direito.

Título - Marinha

Categoria - pintura

Técnica - óleo s/tela

Dimensões -47 x $63 \mathrm{~cm}$

Data - 1995

Assinatura - monogramado no verso (H.A.). Canto inferior direito. 


\section{COLEÇÃO FÁBIO IONESCU}

\section{São Paulo}

Título - Paisagem imaginária

Categoria - pintura

Técnica - óleo s/tela

Dimensões $-61 \times 73,5 \mathrm{~cm}$

Data - 1945

Assinatura - assinado na frente. Canto inferior direito.

Título - Pico da Vitória, (figura 34, no texto)

Categoria - pintura

Técnica - óleo s/tela

Dimensões - 54 x $65 \mathrm{~cm}$.

Data -1937

Assinatura - assinado no verso. Canto inferior direito. 


\section{COLEÇÃO GERALDO MODESTO}

\section{São Paulo}

Título - Figos e Cesta

Categoria - pintura

Técnica - óleo s/tela

Dimensões - 55 x $67 \mathrm{~cm}$.

Data $-\mathrm{s} / \mathrm{d}$

Assinatura - assinado frente e verso. Canto inferior direito.

Título - Natureza-Morta na Praia com Frutas

Categoria - pintura

Técnica - óleo s/tela

Dimensões -50 × $63 \mathrm{~cm}$

Data $-\mathrm{s} / \mathrm{d}$

Assinatura - assinado no verso. Canto inferior direito.

Título - Paisagem com ipê roxo e lago

Categoria - pintura

Técnica - óleo s/tela

Dimensões - 63 x $55 \mathrm{~cm}$

Data - s/d

Assinatura - não assinado

Título - sem título

Categoria - pintura (paisagem com árvore central e montanhas)

Técnica - óleo s/tela

Dimensões - 53 x $61 \mathrm{~cm}$.

Data - s/d 
Assinatura - assinado frente e verso. Canto inferior direito.

Título - sem título

Categoria - pintura (paisagem com vale, pinheiros e estrada)

Técnica - óleo s/tela

Dimensões -63 x $77 \mathrm{~cm}$.

Data $-\mathrm{s} / \mathrm{d}$

Assinatura - assinado no verso. Canto inferior direito.

Título - sem título

Categoria - pintura (paisagem com muro ocre)

Técnica - óleo s/tela

Dimensões - 50 × $63 \mathrm{~cm}$

Data $-\mathrm{s} / \mathrm{d}$

Assinatura - assinado no verso. Canto inferior direito.

Título - sem título

Categoria - pintura (natureza-morta na praia com estátua, conchas e abóbora vermelha)

Técnica - óleo s/tela

Dimensões - 58 x $72 \mathrm{~cm}$.

Data $-\mathrm{s} / \mathrm{d}$

Assinatura - não assinado

Título - sem título

Categoria - pintura (paisagem com pinheiro seco e grande nuvem branca)

Técnica - óleo s/tela

Dimensões -63 x $55 \mathrm{~cm}$.

Data $-\mathrm{s} / \mathrm{d}$

Assinatura - assinado no verso. Canto inferior direito. 
Título - Vaso de flores

Categoria - pintura

Técnica - óleo s/tela

Dimensões -60 × $50 \mathrm{~cm}$

Data $-\mathrm{s} / \mathrm{d}$

Assinatura - não assinado

Título - Auto Retrato, (figura 37, no texto)

Categoria - pintura

Técnica - óleo s/tela

Dimensões -61 x $50 \mathrm{~cm}$

Data -1923

Assinatura - assinado no verso. Canto inferior direito. Etiquetado no verso: XIV-Exposizione Internazionale d'Arte - Venezia, 1924.

Título - Concha e Vaso

Categoria - pintura (natureza-morta)

Técnica - óleo s/tela

Dimensões - 52 × $54 \mathrm{~cm}$

Data -1923

Assinatura - assinado no verso. Canto inferior direito. Etiquetado no verso: exposto em Livorno e Florença

Título - sem título

Categoria - pintura (natureza-morta com peixes pequenos e trigo)

Técnica - óleo s/tela

Dimensões - 50 x $53 \mathrm{~cm}$

Data -1927

Assinatura - assinado na frente e verso. Canto inferior direito. 
Título - Natureza-Morta com Faisões, (figura 8, no texto)

Categoria - pintura

Técnica - óleo s/tela

Dimensões -70 x $80 \mathrm{~cm}$

Data -1932

Assinatura - assinado na frente e verso. Canto inferior direito. Etiqueta no verso: Salon des Tuileries e Salão de Maio

Título - Vista do rio de Janeiro

Categoria - pintura

Técnica - óleo s/tela

Dimensões -70 x $80 \mathrm{~cm}$

Data - 1936

Assinatura - não assinado

Título - Jardim da Luz, (figura 3, no texto)

Categoria - pintura (paisagem)

Técnica - óleo s/tela

Dimensões -67 x $53 \mathrm{~cm}$.

Data - anos 80 .

Assinatura - assinado no verso. Canto inferior direito.

Título - Paisagem azul com Montanhas

Categoria - pintura

Técnica - óleo s/tela

Dimensões - 51 x $64 \mathrm{~cm}$

Data - anos 80.

Assinatura - assinado no verso. Canto inferior direito. 
Título - Homenagem a Guignard

Categoria - pintura (paisagem)

Técnica - óleo s/tela

Dimensões - 50 × $67 \mathrm{~cm}$

Data - anos 90 .

Assinatura - assinado frente e verso. Canto inferior direito.

Título - Homenagem a Pancetti

Categoria - pintura (marinha)

Técnica - óleo s/tela

Dimensões - 50 x $66 \mathrm{~cm}$

Data - anos 90 .

Assinatura - assinado na frente e no verso. Canto inferior direito.

O colecionador possui um desenho de nu feminino da década de vinte, mas não se lembra onde o guardou. 


\section{COLEÇÃO GUIDO TÓTTOLI}

\section{São Paulo}

Título - sem título

Categoria - pintura (paisagem com canoa em dia nublado)

Técnica - óleo s/tela

Dimensões - 29 × 35

Data - anos 20.

Assinatura - assinado no verso. Canto inferior direito.

Título - sem título

Categoria - pintura (paisagem com montanhas em dia nublado)

Técnica - óleo s/tela

Dimensões - 30 × $32 \mathrm{~cm}$

Data - anos 20.

Assinatura - assinado no verso. Canto inferior direito.

Título - Natureza-Morta com Pimentões

Categoria - pintura

Técnica - óleo s/tela

Dimensões - 29 x $35 \mathrm{~cm}$.

Data - 1927

Assinatura - assinado no verso. Canto inferior direito.

Título $-\mathrm{Nu}$

Categoria - desenho

Técnica - grafite s/papel

Dimensões - 45 x $32 \mathrm{~cm}$

Data - anos 20 .

Assinatura - assinado na frente. Canto inferior direito. 
Título $-\mathrm{Nu}$

Categoria - desenho

Técnica - grafite s/papel

Dimensões - 45 × $32 \mathrm{~cm}$

Data - anos 20 .

Assinatura - assinado na frente. Canto inferior direito.

Título - Nu

Categoria - desenho

Técnica - grafite s/papel

Dimensões - 45 × $32 \mathrm{~cm}$

Data - anos 20 .

Assinatura - assinado na frente. Canto inferior direito.

Título $-\mathrm{Nu}$

Categoria - desenho

Técnica - grafite s/papel

Dimensões - 45 x $32 \mathrm{~cm}$

Data - anos 20 .

Assinatura - não assinado

Título $-\mathrm{Nu}$

Categoria - desenho

Técnica - grafite s/papel

Dimensões - 45 x $32 \mathrm{~cm}$

Data - anos 20 .

Assinatura - não assinado

Título - Nu

Categoria - desenho 
Técnica - grafite s/papel

Dimensões -31 x 23,5 cm

Data -1927

Assinatura - assinado na frente com dedicatória. Canto inferior direito.

Com esta mesma medida e técnica, diz possuir em torno de 50 desenhos. Além de possuir um caderno de 30 x $23 \mathrm{~cm}$. com 27 desenhos de Adami, entre nus e rostos. 


\section{COLEÇÃO JOÃO VICENTE DE AZEVEDO}

\section{São Paulo}

Título - Paisagem Lilás

Categoria - pintura

Técnica - óleo s/tela

Dimensões -52 x $65 \mathrm{~cm}$.

Data - anos 80.

Assinatura - assinado na frente. Canto inferior direito.

Título - sem título, (paisagem com montes esverdeados)

Categoria - pintura

Técnica - óleo s/tela

Dimensões -54 x $73 \mathrm{~cm}$.

Data - anos 80 .

Assinatura - assinado frente e monogramado no verso. Canto inferior direito. 


\section{QUADROS ENCONTRADOS COM O MARCHAND JOAQUIM NUNES}

\section{São Paulo}

Título - Pinheiros em Campos do Jordão

Categoria - pintura

Técnica - óleo s/tela

Dimensões - 49,5 x 39,2

Data $-\mathrm{s} / \mathrm{d}$

Assinatura - não assinado

Título - sem título

Categoria - pintura (marinha com árvores, em Ubatuba)

Técnica - óleo s/tela

Dimensões - $40 \times 52 \mathrm{~cm}$.

Data $-\mathrm{s} / \mathrm{d}$

Assinatura - assinado no verso

Título - Marinha em Ubatuba

Categoria - pintura

Técnica - óleo s/tela

Dimensões - 50 x 40

Data - 1975

Assinatura - assinado no verso

Título - Campos do Jordão, (figura 4, no texto)

Categoria - pintura

Técnica - óleo s/ madeira

Dimensões - 39,2 x 49,5 cm.

Data - 1975 
Assinatura - assinado no verso

Título - Paisagem d'este

Categoria - pintura

Técnica - óleo s/tela

Dimensões - 39,5 x 49,5 cm.

Data - 1975

Assinatura - assinado no verso. Canto inferior direito.

Título - Paisagem d'este

Categoria - pintura

Técnica - óleo s/tela

Dimensões - 34,5 x 49,5

Data - 1975

Assinatura - não assinado

Título - Paisagem d'este

Categoria - pintura

Técnica - óleo s/tela

Dimensões - 45,5 x 39,8 cm.

Data - 1975

Assinatura - não assinado

Título - Cabeça de Cristo

Categoria - pintura

Técnica - óleo s/ cartão

Dimensões - 40,5 x 32,5

Data - anos 80.

Assinatura - assinado no verso. Canto inferior direito. 
Título - Nordeste

Categoria - pintura

Técnica - óleo s/tela

Dimensões - 70 x $50 \mathrm{~cm}$

Data - anos 80 .

Assinatura - assinado no verso. Canto inferior direito. 


\section{COLEÇÃO LIA SCHULTZ}

\section{São Paulo}

Título - Morro do Castelo, (figura 12, no texto)

Categoria - pintura

Técnica - óleo s/tela

Dimensões - 57 x $73 \mathrm{~cm}$

Data - 1921

Assinatura - assinado na frente. Canto inferior direito. 


\section{COLEÇÃO LUIZ FERNANDO DA COSTA E SILVA}

\section{São Paulo}

Título - Natureza-Morta com objetos

Categoria - pintura

Técnica - óleo s/tela

Dimensões -68 x $53 \mathrm{~cm}$

Data $-\mathrm{s} / \mathrm{d}$

Assinatura - assinado no verso. Canto inferior direito.

\section{Título - Paisagem}

Categoria - pintura

Técnica - óleo s/tela

Dimensões $-60 \times 73 \mathrm{~cm}$

Data $-\mathrm{s} / \mathrm{d}$

Assinatura - assinado no verso. Canto inferior direito. 


\section{COLEÇÃO ORANDI MOMESSO}

São Paulo

Título - Vaso de Flores e Orquídeas

Categoria - pintura

Técnica - óleo s/tela

Dimensões -65 x $50 \mathrm{~cm}$.

Data - anos 20.

Assinatura - assinado na frente. Canto inferior direito. 


\section{COLEÇÃO OSWALDO DE PAULA SANTOS}

São Paulo

Título - sem título

Categoria - pintura (paisagem com casas)

Técnica - óleo s/tela

Dimensões -60 x $50 \mathrm{~cm}$.

Data $-\mathrm{s} / \mathrm{d}$

Assinatura - assinado na frente. Canto inferior direito. 


\section{COLEÇÃO PAULO DE TARSO AQUARONE}

São Paulo

Título - Cravinas Brancas

Categoria - pintura (natureza-morta)

Técnica - óleo s/tela

Dimensões $-60 \times 70 \mathrm{~cm}$.

Data - 1925

Assinatura - assinado no verso. Canto inferior direito. 


\section{COLEÇÃO ROBERTO DEL NERO}

\section{São Paulo}

Título - Paisagem Toscana, (figura 31, no texto)

Categoria - pintura

Técnica - óleo s/tela

Dimensões - 57 x $60 \mathrm{~cm}$.

Data - 1927

Assinatura - assinado no verso. Canto inferior esquerdo. 


\section{COLEÇÃO ROBERTO FRIZZO}

\section{São Paulo}

Título - Paisagem Rural com Porteira

Categoria - pintura

Técnica - óleo s/tela

Dimensões - 74 × $61 \mathrm{~cm}$

Data $-\mathrm{s} / \mathrm{d}$

Assinatura - Assinado no verso. Canto inferior direito.

Título - sem título

Categoria - pintura (natureza-morta com pêssegos e cerejas)

Técnica - óleo s/tela

Dimensões - 53 x $66 \mathrm{~cm}$.

Data - anos 30 .

Assinatura - assinado na frente. Canto inferior direito.

Título - sem título

Categoria - pintura (natureza-morta com morangos e pêssegos)

Técnica - óleo s/tela

Dimensões - 53 x $66 \mathrm{~cm}$.

Data - anos 30 .

Assinatura - assinado no verso. Canto inferior direito.

Título - Vaso de Flores

Categoria - pintura

Técnica - óleo s/tela

Dimensões - 67 x $54 \mathrm{~cm}$.

Data - anos 90 .

Assinatura - assinado na frente. Canto inferior direito. 


\section{COLEÇÃO ROBERTO IONESCU}

\section{São Paulo}

Título - Arenques Defumados, (figura 29, no texto)

Categoria - pintura

Técnica - óleo s/tela

Dimensões -57 x $70 \mathrm{~cm}$.

Data -1925

Assinatura - assinado na frente. Canto inferior direito.

Título - Lagosta

Categoria - pintura

Técnica - óleo s/tela

Dimensões - 54 x 65,5 cm.

Data - 1926

Assinatura - assinado no verso. Canto inferior direito. 
COLEÇÃO ROSA ADAMI

São Paulo

Título - Retrato de Mulher

Categoria - pintura

Técnica - óleo s/tela

Dimensões - 40 x $30 \mathrm{~cm}$.

Data $-\mathrm{s} / \mathrm{d}$

Assinatura - não assinado

Título - sem título

Categoria - pintura (marinha com canoa ao longe)

Técnica - óleo s/tela

Dimensões -50 x $60 \mathrm{~cm}$.

Data $-\mathrm{s} / \mathrm{d}$

Assinatura - não assinado

Título - sem título

Categoria - pintura (paisagem com pinheiros e monte amarelo)

Técnica - óleo s/tela

Dimensões - 50 x $60 \mathrm{~cm}$.

Data - anos 80.

Assinatura - assinado no verso. Canto inferior direito.

Título - sem título

Categoria - pintura (paisagem de montanha)

Técnica - óleo s/tela

Dimensões - 50 x 60

Data - anos 80 .

Assinatura - monogramado no verso. Canto inferior direito. 
Título - Paisagem, (figura 6, no texto)

Categoria - pintura

Técnica - óleo s/tela

Dimensões - 50 x $60 \mathrm{~cm}$.

Data - anos 90 .

Assinatura - monogramado no verso. Canto inferior direito.

Título - sem título

Categoria - pintura (paisagem com montanhas e pinheiros na frente)

Técnica - óleo s/tela

Dimensões - 50 x $60 \mathrm{~cm}$.

Data - anos 90 .

Assinatura - monogramado no verso. Canto inferior direito.

Título - sem título

Categoria - pintura (paisagem com pinheiro e araucária)

Técnica - óleo s/tela

Dimensões - 50 x 60

Data - anos 90 .

Assinatura - monogramado no verso. Canto inferior direito.

Título - sem título

Categoria - pintura (paisagem com pinheiros no primeiro plano)

Técnica - óleo s/tela

Dimensões - 50 x $60 \mathrm{~cm}$

Data - anos 90 .

Assinatura - monogramado no verso. Canto inferior direito. 
Título - sem título

Categoria - pintura (paisagem com céu amarelo)

Técnica - óleo s/tela

Dimensões -50 × $60 \mathrm{~cm}$

Data - anos 90 .

Assinatura - monogramado no verso. Canto inferior direito.

Título - sem título

Categoria - pintura (paisagem com árvores e céu laranja)

Técnica - óleo s/tela

Dimensões - 50 x 60

Data - anos 90 .

Assinatura - monogramado no verso. Canto inferior direito.

Título - sem título

Categoria - pintura (marinha com montanha)

Técnica - óleo s/tela

Dimensões - 50 x $60 \mathrm{~cm}$.

Data - anos 90 .

Assinatura - monogramado no verso. Canto inferior direito.

Título - sem título

Categoria - pintura (marinha)

Técnica - óleo s/tela

Dimensões - 50 x $60 \mathrm{~cm}$.

Data - anos 90 .

Assinatura - monogramado no verso. Canto inferior direito. 
Título - sem título

Categoria - pintura (marinha)

Técnica - óleo s/tela

Dimensões - 50 x $60 \mathrm{~cm}$.

Data - anos 90 .

Assinatura - monogramado no verso. Canto inferior direito.

Título - sem título

Categoria - pintura (marinha com canoa)

Técnica - óleo s/tela

Dimensões - 50 x $60 \mathrm{~cm}$.

Data - anos 90 .

Assinatura - monogramado no verso. Canto inferior direito.

Título - sem título

Categoria - pintura (marinha)

Técnica - óleo s/tela

Dimensões - 50 x $60 \mathrm{~cm}$.

Data - anos 90 .

Assinatura - monogramado no verso. Canto inferior direito.

Título - sem título

Categoria - pintura (estrada e sol)

Técnica - óleo s/tela

Dimensões -50 x $60 \mathrm{~cm}$.

Data - anos 90 .

Assinatura - monogramado no verso. Canto inferior direito. 
Título - sem titulo

Categoria - pintura (canoa e montanha)

Técnica - óleo s/tela

Dimensões - 50 x $60 \mathrm{~cm}$.

Data - anos 90 .

Assinatura - monogramado no verso. Canto inferior direito.

Título - sem título

Categoria - pintura (paisagem com pinheiros, montanha e cortina)

Técnica - óleo s/tela

Dimensões $-60 \times 70 \mathrm{~cm}$.

Data - anos 90 .

Assinatura - monogramado no verso. Canto inferior direito.

Título - sem título

Categoria - pintura (paisagem com árvores secas e céu amarelo)

Técnica - óleo s/tela

Dimensões $-60 \times 70 \mathrm{~cm}$.

Data - anos 90, (c.)

Assinatura - monogramado no verso. Canto inferior direito.

Título - Casas

Categoria - pintura

Técnica - óleo s/tela

Dimensões - 50 x $60 \mathrm{~cm}$

Data - anos 90 .

Assinatura - monogramado no verso. Canto inferior direito. 
Título - Paisagem do Rio de Janeiro

Categoria - pintura

Técnica - óleo s/tela

Dimensões $-60 \times 70 \mathrm{~cm}$.

Data - anos 90 .

Assinatura - monogramado no verso. Canto inferior direito.

Título - Para Vanessa

Categoria - pintura (natureza-morta, flores)

Técnica - óleo s/tela

Dimensões - 50 × $60 \mathrm{~cm}$

Data - anos 90 .

Assinatura - monogramado na frente. Canto inferior direito.

Título - Por do Sol

Categoria - pintura

Técnica - óleo s/tela

Dimensões $-60 \times 70 \mathrm{~cm}$.

Data - anos 90 .

Assinatura - monogramado no verso. Canto inferior direito.

Título - Por do Sol Vermelho

Categoria - pintura

Técnica óleo - s/ tela

Dimensões $-60 \times 70 \mathrm{~cm}$.

Data - anos 90 .

Assinatura - monogramado no verso. Canto inferior direito. 


\section{COLEÇÃO SÉRGIO HADEMAR E EDI ADAMI}

São Paulo

Título - sem título

Categoria - pintura (marinha)

Técnica - óleo s/tela

Dimensões -23 x $33 \mathrm{~cm}$.

Data - 1917

Assinatura - assinado no verso. Canto inferior direito.

Título - sem título

Categoria - pintura (natureza-morta com peixes e garrafa)

Técnica - óleo s/tela

Dimensões - 50 x $65 \mathrm{~cm}$.

Data - 1930

Assinatura - assinado na frente. Canto inferior direito.

Título - Fábrica, (figura 36, no texto)

Categoria - pintura

Técnica - óleo s/tela

Dimensões -73 x $60 \mathrm{~cm}$.

Data - 1934

Assinatura - assinado no verso. Canto inferior direito.

Título - Favela dos Meus Amores, (figura 35, no texto)

Categoria - pintura (vista da favela)

Técnica - óleo s/tela

Dimensões - 50 × $60 \mathrm{~cm}$

Data - 1934

Assinatura - assinado no verso. Canto inferior direito. 


\section{COLEÇÃO SIMÃO MENDEL GUSS}

\section{São Paulo}

Título - Fim de tarde

Categoria - pintura

Técnica - óleo s/tela

Dimensões - 46 x $55 \mathrm{~cm}$.

Data - anos 70.

Assinatura - assinado na frente. Canto inferior direito.

Título - Paisagem com Hortências

Categoria - pintura

Técnica - óleo s/tela

Dimensões -50 x $65 \mathrm{~cm}$.

Data - anos 70 .

Assinatura - assinado frente e verso. Canto inferior direito.

Título - Paisagem noturna com Hortências

Categoria - pintura

Técnica - óleo s/tela

Dimensões -60 x $50 \mathrm{~cm}$.

Data - anos 70 .

Assinatura - assinado frente e verso. Canto inferior direito.

Título - Paisagem com árvores

Categoria - pintura

Técnica - óleo s/tela

Dimensões -60 × $50 \mathrm{~cm}$

Data - anos 70 .

Assinatura - assinado na frente. Canto inferior direito. 
Título - Paisagem com lago

Categoria - pintura

Técnica - óleo s/tela

Dimensões -50 × $60 \mathrm{~cm}$

Data - anos 70 .

Assinatura - assinado frente e monogramado no verso. Canto inferior direito.

Título - Paisagem com Rochedos

Categoria - pintura

Técnica - óleo s/tela

Dimensões - 50 × $60 \mathrm{~cm}$

Data - anos 70 .

Assinatura - assinado frente e monogramado no verso. Canto inferior direito. 


\section{COLEÇÃO VALÉRIA ADAMI}

São Paulo

Título - Paisagem de São Miguel Paulista

Categoria - pintura

Técnica - óleo s/tela

Dimensões - 28 x 39

Data - 1919

Assinatura - assinado na frente. Canto inferior direito.

Título - Paisagem noturna com luar

Categoria - pintura

Técnica - óleo s/tela

Dimensões - 34,5 x 22,5 cm.

Data -1920

Assinatura - assinado na frente. Canto inferior direito.

Título - San Giminiano (II)

Categoria - pintura (paisagem)

Técnica - óleo s/tela

Dimensões -56 x $68 \mathrm{~cm}$.

Data -1928

Assinatura - assinado no verso. Canto inferior direito.

Título - Natureza-Morta Com Lagosta, (figura 23, no texto)

Categoria - pintura

Técnica - óleo s/tela

Dimensões - 79 x $100 \mathrm{~cm}$. (participou da Bienal de Veneza na década de 30)

Data - anos 30 . 
Assinatura - assinado na frente. Canto inferior direito.

Título - Paisagem de lago com por do sol

Categoria - pintura

Técnica - óleo s/tela

Dimensões - 43 x $54 \mathrm{~cm}$.

Data - anos 80 .

Assinatura - assinado na frente. Canto inferior direito.

Título - Poluição

Categoria - pintura (paisagem urbana)

Técnica - óleo s/tela

Dimensões - 43 x $54 \mathrm{~cm}$

Data - anos 80 .

Assinatura - assinado na frente. Canto inferior direito.

Título - sem título

Categoria - pintura (natureza-morta com caju)

Técnica - óleo s/tela

Dimensões - 39 x $54 \mathrm{~cm}$.

Data - anos 80.

Assinatura - assinado no verso. Canto inferior direito.

Título - sem título

Categoria - pintura (natureza-morta com gamela)

Técnica - óleo s/tela

Dimensões - 39 x $54 \mathrm{~cm}$

Data - anos 80.

Assinatura - assinado no verso. Canto inferior direito. 


\section{OBRAS COM O PARADEIRO IGNORADO}

Título - Araguaia

Categoria - pintura

Técnica - óleo s/tela

Dimensões - 50 x $60 \mathrm{~cm}$.

Data $-\mathrm{s} / \mathrm{d}$

Título - Bambuzal

Categoria - pintura

Técnica - óleo s/tela

Dimensões -50 x $60 \mathrm{~cm}$.

Data $-\mathrm{s} / \mathrm{d}$

Coleção - Mônica Giachini, (?)

Título - Barrancos

Categoria - pintura

Técnica - óleo s/tela

Dimensões -60 x $50 \mathrm{~cm}$.

Data $-\mathrm{s} / \mathrm{d}$

Coleção - New Building Const. E Incorp. LTDA, (?)

Título - Cerca florida

Categoria - pintura

Técnica - óleo s/tela

Dimensões -50 x $65 \mathrm{~cm}$.

Data $-\mathrm{s} / \mathrm{d}$ 
Título - Falésia com escadaria

Categoria - pintura

Técnica - óleo s/tela

Dimensões $-60 \times 50 \mathrm{~cm}$.

Data $-\mathrm{s} / \mathrm{d}$

Coleção - New Building Const. E Incorp. LTDA, (?)

Título - Frutas e Nozes

Categoria - pintura

Técnica - óleo s/tela

Dimensões - 21,5 x 27,5 cm.

Data $-\mathrm{s} / \mathrm{d}$

Coleção - Risoleta Barata, (?)

Título - Januária

Categoria - pintura

Técnica - óleo s/tela

Dimensões - 50 x $65 \mathrm{~cm}$.

Data $-\mathrm{s} / \mathrm{d}$

Coleção - Partinvest Agr. E Com. LTDA, (?)

Título - Nascente

Categoria - pintura

Técnica - óleo s/tela

Dimensões - 56 x $71 \mathrm{~cm}$.

Data - s/d

Coleção - Maria Lúcia de Oliveira, (?)

Título - Paisagem com água 
Categoria - pintura

Técnica - óleo s/tela

Dimensões - 65 x $50 \mathrm{~cm}$.

Data $-\mathrm{s} / \mathrm{d}$

Título - Pantanal I

Categoria - pintura

Técnica - óleo s/tela

Dimensões $-60 \times 73 \mathrm{~cm}$.

Data - s/d

Título - Pantanal II

Categoria - pintura

Técnica - óleo s/tela

Dimensões $-60 \times 73 \mathrm{~cm}$.

Data - s/d

Título - Porteira

Categoria - pintura

Técnica - óleo s/tela

Dimensões - 50 x $60 \mathrm{~cm}$.

Data $-\mathrm{s} / \mathrm{d}$

Título - Rio São Francisco

Categoria - pintura

Técnica - óleo s/tela

Dimensões - 50 x $60 \mathrm{~cm}$.

Data $-\mathrm{s} / \mathrm{d}$

Coleção - Grunatur - Grupo Nacional de Turismo LTDA, (?) 
Título - A árvore

Categoria - pintura

Técnica - óleo s/tela

Data - anos 20, (c.)

Título - Casas de colonos

Categoria - pintura

Técnica - óleo s/tela

Data - anos 20, (c.)

Título - Convento Velho

Categoria - pintura

Técnica - óleo s/tela

Data - anos 20, (c.)

Título - Natureza-Morta com beringelas

Categoria - pintura

Técnica - óleo s/tela

Data - anos 20.

Título - Paisagem de Florença

Categoria - pintura

Técnica - óleo s/tela

Dimensões - sem referência

Data - anos 20.

Coleção - Pietro Maria Bardi, quadro dedicado a Theodore Breger (?) 
Título - Retrato da mãe de Adami

Categoria - pintura

Técnica - óleo s/tela

Data - anos 20.

Título - Retrato de Menotti del Picchia

Categoria - pintura

Técnica - óleo s/tela

Data - anos 20.

Título - San Giminiano

Categoria - pintura

Técnica - óleo s/tela

Data - anos 20.

Título - San Giminiano

Categoria - pintura

Técnica - óleo s/tela

Data - anos 20.

Título - Vilarejo toscano

Categoria - pintura

Técnica - óleo s/tela

Data - anos 20.

Título - Casas nos arredores de Florença

Categoria - pintura

Técnica - óleo s/tela 
Dimensões -57 x 70,5 cm.

Data - 1927

Coleção - Francisco Márcio da Costa Carvalho, (?)

Título - San Giminiano (I), (figura 32, no texto)

Categoria - pintura

Técnica - óleo s/tela

Dimensões - 57 x 70,5 cm.

Data -1927

Coleção - Luigi Cavalieri, (?)

Título - Cogumelos

Categoria - pintura

Técnica - óleo s/tela

Dimensões - sem medidas

Data - 1929

Título - Cabeça de Etrusco

Categoria - pintura

Técnica - óleo s/tela

Data - anos 30.

Título - Ilha de Paquetá

Categoria - pintura

Técnica - óleo s/tela

Dimensões -70 × $90 \mathrm{~cm}$

Data - anos 30

Coleção - Júlio Vitor Lorenti, (?) 
Título - Retrato de Graciliano Ramos

Categoria - pintura

Técnica - óleo s/tela

Data - anos 30 .

Título - Retrato de Jovita do Amaral

Categoria - pintura

Técnica - óleo s/tela

Data - anos 30.

Título - Figura de Mulher (figura 38 no texto)

Categoria - pintura (retrato)

Técnica - óleo s/tela

Dimensões - 65 x $54 \mathrm{~cm}$.

Data - 1930 - 1932, (c.)

Assinatura - assinado no verso

Título - Paisagem com milho seco

Categoria - pintura

Técnica - óleo s/tela

Dimensões - 54 x $73 \mathrm{~cm}$.

Data -1932

Título - sem título

Categoria - pintura

Técnica - óleo s/tela

Dimensões - 57 x $70 \mathrm{~cm}$.

Data - 1933 
Coleção - Olinda Barros Monteiro, (?)

Título - Marrecos

Categoria - pintura

Técnica - óleo s/tela

Dimensões - 54 x $65 \mathrm{~cm}$.

Data -1933

Coleção - Mônica Giacchini, (?)

Título - Natureza-Morta com alcachofra e ovos

Categoria - pintura

Técnica - óleo s/tela

Dimensões - sem medidas

Data - 1933

Título - Flores

Categoria - pintura

Técnica - óleo s/tela

Dimensões -65 x $55 \mathrm{~cm}$.

Data - 1933

Coleção - H. Richetti, (?)

Título - Casas em Saint Deniz

Categoria - pintura

Técnica - óleo s/tela

Dimensões - sem medidas

Data - 1945

Título - Marinha de Pirangi do Sul

Categoria - pintura 
Técnica - óleo s/tela

Dimensões - 50 × $65 \mathrm{~cm}$.

Data - 1961

Coleção - Maria Lúcia de Oliveira, (?)

Título - Marinha da Ilha Porchat

Categoria - pintura

Técnica - óleo s/tela

Dimensões - 50 × $65 \mathrm{~cm}$.

Data - 1963

Coleção - Maria Lúcia de Oliveira, (?)

Título - Queimada

Categoria - pintura

Técnica - óleo s/tela

Dimensões -40 x $50 \mathrm{~cm}$.

Data - 1972

Coleção - Rodrigo Adami, Tableau

Título - Marinha de Ipanema

Categoria - pintura

Técnica - óleo s/tela

Dimensões - 50 x $65 \mathrm{~cm}$.

Data - 1974

Coleção - MTF Const. E Incorp. LTDA, (?)

Título - Crepúsculo

Categoria - pintura

Técnica - óleo s/tela 
Dimensões - 50 x $60 \mathrm{~cm}$.

Data - 1975

Coleção - MTF Const. Incorp. LTDA, (?)

Título - Marinha

Categoria - pintura

Técnica - óleo s/tela

Dimensões -50 x $60 \mathrm{~cm}$.

Data - 1978

Coleção - Ernesto Sampaio Vidal Filho, (?)

Título - Marinha com Casa

Categoria - pintura

Técnica - óleo s/tela

Dimensões - 45 x $55 \mathrm{~cm}$.

Data - 1978

Coleção - Rodrigo Adami, Tableau

Título - Montanha com Árvores

Categoria - pintura

Técnica - óleo s/tela

Dimensões - 45 x $55 \mathrm{~cm}$.

Data - 1978

Coleção - Rodrigo Adami, Tableau

Título - Enchente

Categoria - pintura

Técnica - óleo s/tela

Dimensões - 50 × $65 \mathrm{~cm}$ 
Data - 1980

Coleção - Ana Ducco, (?)

Título - Mata

Categoria - pintura

Técnica - óleo s/tela

Dimensões - 50 x $65 \mathrm{~cm}$.

Data - 1980

Coleção - Milton Fernandes, (?)

Título - Natureza-Morta

Categoria - pintura

Técnica - óleo s/tela

Dimensões - 40 x $50 \mathrm{~cm}$.

Data - anos 80.

Coleção - Rodrigo Adami, Tableau

Título - Paisagem, (figura 1 no texto)

Categoria - pintura

Técnica - óleo s/tela

Dimensões - 50 x $65 \mathrm{~cm}$.

Data - 1980

Título - Paisagem, (figura 5 no texto)

Categoria - pintura

Técnica - óleo s/tela

Dimensões - 50 x $60 \mathrm{~cm}$.

Data - 1980 
Título - Paisagem

Categoria - pintura

Técnica - óleo s/tela

Dimensões - 50 x $60 \mathrm{~cm}$.

Data - 1980

Coleção - Josef Levi, (?)

Título - Periferia

Categoria - pintura

Técnica - óleo s/tela

Dimensões - 50 x $65 \mathrm{~cm}$.

Data - 1980

Coleção - Stefano Cavaliere, (?)

Título - Solidão

Categoria - pintura

Técnica - óleo s/tela

Dimensões - 50 x $65 \mathrm{~cm}$.

Data - 1980

Coleção - Celso Guarita M. Russomano, (?)

Título - Campos do Jordão

Categoria - pintura

Técnica - óleo s/tela

Dimensões - 50 x $65 \mathrm{~cm}$.

Data - 1982

Coleção - New Building Const. E Incorp. LTDA, (?) 
Título - Clareira

Categoria - pintura

Técnica - óleo s/tela

Dimensões - 50 x $60 \mathrm{~cm}$.

Data - 1982

Coleção - Roberto Pereira de Castro, (?)

Título - Fazenda volta Grande

Categoria - pintura

Técnica - óleo s/tela

Dimensões - 50 x $65 \mathrm{~cm}$.

Data - 1982

Título - Margens do Rio

Categoria - pintura

Técnica - óleo s/tela

Dimensões -50 x $65 \mathrm{~cm}$.

Data - 1982

Coleção - Teresa François, (?)

Título - Natureza-Morta na Praia, (figura 2, no texto)

Categoria - pintura

Técnica - óleo s/tela

Dimensões - 50 x $65 \mathrm{~cm}$.

Data - 1982

Título - Os Pássaros

Categoria - pintura

Técnica - óleo s/tela 
Dimensões - 50 x $60 \mathrm{~cm}$.

Data - 1982

Coleção - Alida L., (?)

Título - Cipreste

Categoria - pintura

Técnica - óleo s/tela

Dimensões - 50 x $65 \mathrm{~cm}$.

Data - 1983

Coleção - Ernesto Sampaio Vidal Filho, (?)

Título - Marinha com algas

Categoria - pintura

Técnica - óleo s/tela

Dimensões - 50 x $60 \mathrm{~cm}$.

Data - 1983

Coleção - Renato de Luigi, (?)

Título - Natureza-Morta na Praia

Categoria - pintura

Técnica - óleo s/tela

Dimensões - 50 x $60 \mathrm{~cm}$.

Data - 1983

Título - Paineira

Categoria - pintura

Técnica - óleo s/tela

Dimensões - 50 x $60 \mathrm{~cm}$.

Data - 1983 
Coleção - Boris Kaufman, (?)

Título - Casas com Varanda

Categoria - pintura

Técnica - óleo s/tela

Dimensões - 50 x $60 \mathrm{~cm}$.

Data - 1984

Coleção - Eliana Marinho, (?)

Título - Paisagem

Categoria - pintura

Técnica - óleo s/tela

Dimensões - 50 x $65 \mathrm{~cm}$.

Data - 1984

Coleção - Stefano Cavaliere, (?)

Título - Portas

Categoria - pintura

Técnica - óleo s/tela

Dimensões -65 x $50 \mathrm{~cm}$.

Data - 1984

Coleção - Newton de Oliveira, (?)

Título - Tempestade

Categoria - pintura

Técnica - óleo s/tela

Dimensões -50 x $60 \mathrm{~cm}$.

Data - 1984

Coleção - Pascoal Amêndola, (?) 
Conforme depoimento de Hugo Adami para Antônio Hélio Cabral em 1976 (museu Lasar Segall) e para Maria Cecília Kunigk, em 1997, (residência do artista na Aclimação), talvez ainda existam na Itália alguns quadros seus do que chamou: experiência Futurista. 


\section{ANEXO 4 \\ ENTREVISTAS COM HUGO ADAMI}

Entrevista do artista Hugo Adami concedida a Maria Cecília Kunigk e à autora, em outubro de 1997, em sua residência no bairro da Aclimação em São Paulo.

Fita 1, lado A.

M.C. - Quais as fases de sua pintura?

H.A - Houve uma fase, um desenvolvimento natural, pelas coisas que vão acontecendo em torno da gente.

M.C. - O senhor começou a pintar ainda moço?

H.A. - De criança. Eu era garotinho, já pintava com tintas. Não larguei a pintura. É uma coisa que está comigo, brota; está dentro de mim.

M.C - O senhor foi influenciado por algum artista?

H.A - Eu tive uma vida muito cheia de relações, que foram surgindo em contato com pessoas... fui também ator da companhia Leopoldo Fróes.

M.C. - Quando?

H.A. - Quando eu era jovem. Mas não durou muito porque o Leopoldo Fróes, grande ator brasileiro, viu um dia um trabalho meu, uma paisagem com árvore e sol e me aconselhou a pintar mais. O Zé Paulista, que era colunista, chamou o quadro de gargalhada do sol e sem eu saber, inscreveu o quadro no Salão de Belas Artes do Rio. Ganhei uma medalha de prata e assim, com esse quadro, larguei o teatro, para me dedicar só à pintura. ${ }^{193}$ (silêncio) Nasci dia 8 de dezembro, dia de Nossa Senhora da Conceição. A minha mãe foi me registrar no ano seguinte, no dia 6 de janeiro. Ela achou interessante fazer isso, porque eu ganharia um ano.

M.C. - E sua pintura metafísica?

H.A. - É chamada metafísica, mas é a opinião de quem vê. Estão me filiando à pintura metafísica de De Chirico. Eu me lembro desta exposição. Eu cheguei em Florença e fui tomar um café. Um que tinha ali na praça, o Giube Rosse. Quando cheguei lá, na mesa ao lado havia 3 pessoas. Otoni Rosai, Berto Ricci...Um deles disse: “de onde você é da Itália?” Disse que eu era brasileiro e começaram a se divertir às minhas custas, cobras, índios... Esses 3 caras foram

${ }^{193}$ Fato ocorrido em 1921. 
formidáveis em minha vida. Um foi Otoni Rosai, um grande pintor; Berto Ricci, crítico de arte... e o outro..... "Então venha conosco visitar uma exposição", disseram, era a exposição de De Chirico, a pintura metafísica.

M.C. - E o senhor gostou da exposição?

H.A. - No início levei um choque. Não posso dizer que tenha gostado. Um cara que sai do Brasil e encontra lá um mundo completamente oposto ao que era o Brasil daqueles tempos. Eu olhei os quadros de De Chirico e fiquei impressionado com aqueles símbolos, aquelas imagens oníricas. Voltei lá umas três vezes, até que um dia De Chirico veio conversar comigo. Ele me perguntou se eu gostava da pintura dele e eu respondi que não sabia se gostava, mas que me intrigava muito. Os símbolos, as imagens fora da realidade comum. Nos tornamos bons amigos. M.C. - Como então o senhor classificaria sua pintura?

H.A. - Eu não sei como classificar minha pintura. É uma pintura que tem um certo Realismo e nada mais. Quem tem que ver coisas são os outros. Não se pode pintar senão com a emoção. Pintar era uma necessidade minha. Exteriorizava através da pintura e do teatro.

M.C. - E sua pintura sempre teve esse Realismo? Sempre pintou paisagens?

H.A. - Pintei muitas paisagens. O tempo que passei na Itália foi uma época maravilhosa, vendo a pintura de De Chirico.

M.C. - Teve outro artista importante para o senhor?

H.A. - Carena, Rosai..., mas não como influência, cada um com sua personalidade ou modo de ser.

M.C. - O senhor não identifica influências que recebeu?

H.A. - Não, não. Não tem influência. Assim, a minha única influência foi Cézanne. Ele criou todo aquele movimento moderno.

M.C - Qual foi seu interesse em Cézanne?

H.A. - Era um novo Realismo, formidável. Não era uma pintura vazia, estéril. Despertava muita força. Cézanne foi o mestre da pintura moderna.

M.C. - O senhor estudou na Itália?

H.A. - Nunca fiz curso nenhum. Fui pintando, convivendo com artistas e realizando minha obra.

M.C. - O senhor sempre gostou do Realismo na pintura? 
H.A. - O Realismo é uma coisa da qual você não pode se afastar totalmente. Você tem que reproduzir o que está vendo. Nessa passagem que existe entre eu e o gesto é que existe o célebre. M.C. - Por quê?

H.A. - Não se tem nenhum interesse nessa pintura abstrata...

M.C. - O senhor pertenceu a algum grupo de artistas?

H.A. - Nunca pertenci a grupo nenhum. Sempre estive sozinho, nunca me filiei a escola, grupos, nada disso.

M.C. - Não pertenceu ao Grupo Santa Helena?

H.A. - Não, absolutamente.

M.C. - O senhor fez algumas exposições na Itália?

H.A. - Sabe que eu não lembro se fiz alguma exposição na Itália... Em Veneza, na Bienal de Veneza.

M.C. - O senhor foi convidado?

H.A. - Não. Foi a base de júri. Você manda o trabalho, aí, cinco artistas julgam se a obra pode ficar ou não. Eu sempre fiquei. Aí na Bienal de Veneza que eu comecei a desenvolver. Era o maior acontecimento na Europa, e eu fui muito bem.

M.C. - E no Brasil, muitas exposiç̧̃es?

H.A. - Não sou muito de exposições. Sou meio preguiçoso.

M.C. - Mas o senhor sempre trabalhou, sempre viveu em função da arte?

H.A. - Claro, mas eu tive meios próprios. Vim de uma família muito abastada, meu pai tinha uma fábrica de tecidos naquela época e me mandava dinheiro para eu ficar sossegado. Tive um pai maravilhoso.

M.C. - Seu pai sempre apoiou sua carreira?

H.A. - Sempre apoiou. Tinha orgulho de ter um filho pintor. Tive pai e mãe maravilhosos. Me lembro que minha mãe um dia me pegou pela mão e disse: "Sabe o que você é, meu filho? Um diabo. Eu pus no mundo um diabo, porém, um bom diabo". Existe um bom diabo...

M.C. - Sei que seus pais eram italianos, porque vieram para o Brasil?

H.A. - Eles necessitavam de um ambiente novo para se desenvolverem. Não vieram como imigrantes, já tinham um encosto, compraram passagem. Meu pai tinha a segunda maior fábrica de tecidos no Brasil. Tecidos de casimira, lá no Brás. A indústria chamava-se Tecelagem Brasil. 
Fita 1, lado B.

M.C. - É verdade que o senhor gostava de canto?

H.A. - Eu gostava de cantar. Tinha voz boa de barítono. Naquele tempo fui muito amigo de artistas como Mário Pinheiro e outros. As companhias líricas traziam elementos formidáveis naquele tempo...

M.C. - O senhor não pensa em voltar a pintar?

H.A. - Não, não mais. Não há mais necessidade. Descanso um pouco a cabeça.

M.C. - O senhor pintava suas paisagens ao ar livre ou em casa, no atelier?

H.A. - Em geral pintava sempre no local, pintava diretamente. Uma vez ou outra que não.

M.C. - Com cavalete?

H.A. - É eu me lembro, pintava com cavalete. Numa ocasião eu estava... Está acontecendo um fenômeno muito curioso comigo: a noite, quando vou para cama, existe uma espécie de magia que me leva ao que já fiz em outras épocas. É um sonho cheio de novas revelações. Me lembro que em um desses sonhos eu estava em Sorrento, uma bela cidade. Estava pintando uma paisagem de lá quando chegou perto de mim um senhor de aparência forte, com uma bengala na mão que disse: "Me permite que veja o que pinta?" Eu então continuei pintando e ele ali, por uns quinze minutos me vendo pintar. De repente, ele falou: "Giovane, tu sei um bravo pittore". E dizendo isso, se afastou. Depois de alguns dias, eu estava em Nice tomando um café quando avistei esse mesmo senhor do outro lado da rua. Perguntei então ao cara que estava comigo quem era aquele senhor. Meu companheiro respondeu que aquele era o maior escritor russo, Leon Tolstoi. Ele elogiou minha pintura... Quando vou para a cama, tudo volta de novo, um Realismo extraordinário, inclusive revelações de coisas que já estavam esquecidas. Voltam uma beleza. Vale a pena ir para a cama, para relembrar esses contatos maravilhosos.

M.C. - O senhor só se interessou por paisagens?

H.A. - Fiz alguns retratos e alguns nus bonitos na pintura.

M.C. - O senhor conheceu Morandi?

H.A. - Conheci todos, quase pessoalmente. Convivi com todos os pintores italianos. (silêncio).

M.C. - Teve alguma fase mais importante em sua vida?

H.A. - Tudo é importante, é difícil responder. Florença é uma cidade mágica.

M.C. - O que o senhor tem a dizer sobre sua arte, sobre a simplicidade, a pureza? 
H.A - Reproduzir numa tela o que estava se passando em torno da gente. Eu reproduzia a paisagem copiando do natural. Do natural para a tela. Sempre fui estimulado pela imagem já realizada. Pintura é uma fuga extraordinária. É uma fuga de todos nós, da vida miserável que a gente vive. Pintura é uma coisa mágica, para mim, é isso. E o Realismo é uma pintura real, uma pintura física.

M.C. - Sua pintura é mais física ou metafísica?

H.A - De vez em quando, surgiam aspectos metafísicos, mas eram fases, momentos diferentes. M.C. - O senhor considera sua pintura pura?

H.A. - Sim, é direta, não tem artifício nenhum. Procuro uma pintura direta, simples, de modo que todo mundo participe. Nada que necessite de explicação; é o Realismo puro, direto, sem artifício nenhum.

M.C. - Como o senhor usava as cores? Como escolhia as cores para pintar, era intuitivo?

H. A. - Não há paleta, você tem vários tons, vai misturando e vai pintando. Punha um pouquinho de cada tinta.

Entrevista do artista Hugo Adami, concedida à autora, realizada na casa de repouso onde se encontrava então já com 100 anos de idade, no bairro Ana Rosa, em São Paulo, no dia 15 de dezembro de 1999.

Fita 2, lado A.

I.P. - O senhor conheceu Mário de Andrade, Tarsila do Amaral....

H.A. - Conheci todos eles, todos os pintores daquela época eu conheci.

I.P. - O senhor ajudou, vamos dizer assim, a realizar a Semana de Arte Moderna em 1922?

H.A. - Ajudei. Naquela época eu tinha idade já para compreender, para participar.

I.P. - Vocês conversavam muito, faziam reuniões?

H.A. - Fazíamos reuniões, foi uma época muito boa para o desenvolvimento da pintura.

I.P. - Então por que o senhor não mostrou nenhum quadro seu na exposição da Semana de $22 ?$

H.A. - Não dá para eu explicar as razões por não ter mostrado um quadro, já faz muito tempo. I.P. - Mas o Mário de Andrade o senhor conheceu, então? 
H.A. - Muito. Mário era muito meu amigo, escreveu vários artigos sobre o meu trabalho.

I.P. - Vocês conversavam muito sobre pintura?

H.A. - É uma pergunta difícil, pois ou falávamos de pintura, ou falávamos de mulher.

I.P. - Logo quando chegou à Europa, o senhor estudou na academia de artes de Florença.

Lembra-se de seus professores?

H.A. - Carena.

I.P. - Quanto tempo estudou lá?

H.A. - Não me lembro...

I.P. - Quando de volta da Europa, no início da década de trinta, o senhor participou de uma peça de teatro de Flávio de Carvalho, "O bailado do deus morto".

H.A. - É, lembro de ter participado. O Flávio de Carvalho era meu amigo e de todo mundo, ele era muito acessível, muito fácil, não tinha problemas.

I. P. - Se lembra por que o Flávio de Carvalho o chamou para participar daquela peça?

H. A. - Não me lembro disso.

I.P. - O senhor estudou com um professor italiano, o Barchitta; sabe por que ele veio para o Brasil?

H. A. - Veio por conta dele. Ele conheceu Aprígio Gonzaga, aquele diretor da Escola Profissional do Brás que o convidou para dar aulas na escola.

I.P. - E como era a pintura dele?

H. A. - Era Realismo, ele pintava o que via. Uma maçã era uma maçã, uma banana, uma banana. Não tinha aquela deformação, não tinha aquela nova revelação de realidade. Era uma pessoa muito boa. Um professor muito bom, foi meu primeiro professor.

I.P. - Quanto tempo foi aluno dele?

H. A. - Uns seis ou sete anos. A Escola Profissional foi fundada ali no Brás, no largo da Concórdia, e eu fui aluno dessa escola. Ganhei medalha de ouro lá.

I.P. - Mais tarde, o senhor chegou também a decorar bailes de Carnaval, não foi?

H. A. - Sim, acho que foram dois bailes e carnaval de rua também. Tudo isso no Rio de Janeiro.

Fita 2, lado B

I.P - E o Teatro da Experiência, o senhor se lembra que papel fez na peça "O bailado do deus morto"? 
H. A. - Era uma coisa extravagante, meio irreal, para aquela época, era uma coisa nova. I.P. - Quase me esqueço de mencionar outro professor seu, o Alfredo Norfini...

H. A. - Foi meu professor lá no Liceu... Um navio de guerra esteve aqui em São Paulo, eu fiz o retrato do almirante do navio. Foi exposto, e ele então, como reconhecimento me deu um relógio de ouro. Está num tabelião a prova de que ganhei o relógio.

I. P. - E o que fez com o relógio?

H. A. - Eu dei à uma moça...

I. P. - E do movimento Novecentista, o senhor se lembra?

H. A. - É, era uma exposição de pintura. O apresentador era Mussolini, era o primeiro governador do estado e veio inaugurar essa exposição. Quando ele veio diante do meu quadro, o meu colega pintor disse: "Excelência, o Adami é um braziliano", então o Mussolini olhou para mim e falou: “Tu és um bom braziliano, conheces muito da Itália”. Eu fiquei lá na Itália uns cinco ou seis anos, depois retornei ao Brasil e daí, voltei de novo para a Itália. Foi uma época muito boa, formidável. 


\section{BILBLIOGRAFIA}

\section{TEXTOS SOBRE HUGO ADAMI}

“Adami, 86 anos e ainda pode surpreender”. Jornal da Tarde. São Paulo, 10/04/1986.

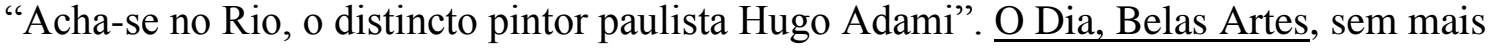
referências.

ANDRADE, Mário de. "Hugo Adami”. Diário Nacional. São Paulo, p. 07, 08/09/1928.

ANDRADE, José Roberto. "O modernista esquecido". Folha de S. Paulo, Mais, p. 22, $19 / 03 / 2000$.

“A volta de Adami”. Folha da Tarde. São Paulo, 02/04/1986.

BARATA, Mário. "Dados historico-críticos sobre Hugo Adami”. São Paulo: Instituto Cultural Itaú, centro de informática e cultua, 1991. “Época e visualidade na pintura de Hugo Adami”. Catálogo da exposição Hugo Adami, São Paulo, MAM, 1986.

BARIONE, Walter. "Sobre o Pintor Hugo Adami," artigo de jornal sem referências.

BRANDÃO, Francisco. "Modernista continua a pintar aos 97 anos.” O Estado de S. Paulo, Seu Bairro, p. 6, 07/06/1997.

DEL MASSA, Aniceto. “La V Mostra Nazionale d'Arte”. La Nazione, 10/05/1931.

D’HORTA, Vera. “Três bons artistas e uma sugestão aos jovens". Folha de S. Paulo, Ilustrada. São Paulo, p. 19, s/d.

"Hugo Adami, uma vida dedicada à pintura". Jornal das Artes, Personalidade Artística. São Paulo, p. 9, outubro/novembro de 1992.

“Il Convegno d'Arte”. Cronache D’Arte. Itália, sem mais referências.

LIMA, Yone Soares. “Encontro com Hugo Adami”. Folha de S. Paulo, Ilustrada. São Paulo, 28/03/1988.

MAGNI, Verano. "Hugo Adami: pittore”. Giornalle. Itália, sem mais referências. "L'Anta e il Selvaggio" .Giornalle. Itália, 28/05/1927.

MARTINS, Luiz. “Hugo Adami”. O Estado de S. Paulo. São Paulo, p.12, 18/08/1976. “Semana movimentada com Volpi e Adami”. Folha de S. Paulo. 09/04/1986. TINTI, Mário. “Il convegno d'arte”. Cronache D’Arte, sem mais referências. 


\section{LIVROS, TESES E DISSERTAÇÕES}

ABBUD, Marísia Costa. Mário de Andrade e as Manifestações Artísticas em São Paulo (1927 - 1930). São Paulo : ECA/USP, 1993. (dissertação de mestrado) ABSE, Tobias. Rethinking Fascism New York: The N.Y. University Press, p.52-58, s/d. AMARAL, Aracy. Arte para quê? São Paulo: Nobel, 1984. Artes Plásticas na Semana de 22. São Paulo: Perspectiva, 1973. Da Feijoada ao X Burguer. São Paulo: Nobel, 1987. Tarsila: sua obra e seu tempo. V.I e II. São Paulo: Perspectiva/EDUSP,

1975.

ALMEIDA, Paulo Mendes de. De Anita ao Museu. São Paulo: Perspectiva, 1976.

AQUARONE, Francisco. História da Arte no Brasil. Rio de Janeiro: Oscar Maro \& Cia, 1939.

ARGAN, Giulio Carlo. Arte Moderna. São Paulo: Cia das Letras, 1992. Guia de História da Arte. Lisboa: Estampa, 1992. História da Arte como História da Cidade. São Paulo: Martins

Fontes, 1992.

ÁVILA, Affonso. O Modernismo. São Paulo: Perspectiva, 1975.

BARGELLINI, Piero. Il Caffè Michelangiolo. Firenze: Vallechi, 1944.

BARDI, Pietro Maria. O Modernismo no Brasil. Brasília: Banco Francês e Italiano p/ a América do sul, 1978.

BAROCCHI, Paola. Storia moderna dell'arte in Italia. Torino: Einaudi, 1990.

BELLUZO, Ana Maria de M. (org.). Modernidade: vanguardas artísticas na América Latina. São Paulo: UNESP, 1990.

BENDINELLI, Goffredo. Compendio di storia dell'arte italiana del seicento ai giorni nostri. Milano: Allighi, Segati \& Cia, 1933.

BERNARDINI, Aurora F. O Futurismo italiano: manifestos. São Paulo: Perspectiva, 1980.

BIGONGIARI, Piero. L’opera completa di Carrà. Milano: Rizzoli, s/d.

BONI, Luiz. A presença italiana no Brasil. Porto Alegre: Escola Superior de Teologia, 1987.

BOSSAGLIA, Rossana et. al. Il Novecento italiano: storia, documenti, iconografia. Milano: FELTRINELLI, 1979.

BRINTON, Crane, CHRISTOFER, John e WOLF, Robert. A history of civilization, v.II. Nova Jersey: Prentice Hall Inc., s/d. 
BRION GUERRY, Liliane. Cézanne et l'expression de l'espace. Paris: Michel, 1966.

BRILL, Alice. Mário Zanini e seu tempo. São Paulo: Perspectiva, 1984.

BRITTO, Mário da Silva. Antecedentes da Semana de Arte Moderna. São Paulo: Saraiva, 1978.

BRUGHETTI, R. Pintura italiana del siglo XX. Buenos Aires: Associación Dante Alighieri, 1967.

CALVESI, Maurizio. La metafisica schiarita: da De Chirico a Carrà, da Morandi a Savino. Milano: Feltrinelli, 1982.

CAMARGOS, Márcia. Villa Kyrial: crônica da belle époque brasileira. São Paulo: Senac, 2000.

CANSOLI, T.Chiesa di San Giuseppe.http:/www.Scordia nell sito della Chiesa [Scordia Delle Provincie], s/d.

CARLUCCIO, Luigi. La faccia nascosta della luna: scritti scelti. Itália: Umberto Alemandi \& Cia, 1974.

CARRÀ, Carlo, a cura de CARRÀ, Massimo. Tutti gli scritti. Milano: Feltrinelli, 1978.

CENNI, Franco. Italianos no Brasil. São Paulo: Martins Fontes, s/d.

CHASTEL, André. A arte italiana. São Paulo: Martins Fontes, 1982.

CHEVALIER, Jean. Dicionário de símbolos. Rio de Janeiro: José Olímpio, 1988.

CHIARELLI, Tadeu. Arte internacional brasileira. São Paulo: Lemos, 1999.

De Almeida Jr. a Almeida Jr.: a crítica de Mário de Andrade, v. I e II.

São Paulo: ECA/USP. (tese de doutorado).

Um Jeca nos Vernissages. São Paulo: EDUSP, 1995.

CHIPP, Hershel B. Teorias da arte contemporânea. São Paulo: Marins Fontes, 1992.

CLARK, Kenneth. A paisagem na arte. Lisboa: Ulisséia, 1961.

COELHO, Teixeira. Moderno Pós Moderno: modos e visões. São Paulo: Iluminuras, 1995.

CONSTANTINI, Vicenzo. Scultura e pittura italiana contemporanea $(1880-1926)$.

Milano: Ulrico Hoepli, 1940.

COWLING, Elizabeth e MUNDY, Jennifer. On classic ground: Picasso, Léger, De Chirico And the new classicism 1910-1930. London: Tate Gallery, 1990.

CRISPOLTI, Enrico. Pittura d' avanguardia nel dopoguerra in Europa. Milano: Fratelli Fabri, 1970.

DELL'ARCO, Maurizio Fagiolo. Scuola Romana: pittura e scultura a Roma dal 1919 al 1943. Roma: De Lucca, 1986.

La vita di Giorgio De Chirico. Torino: U. Alemandi, 1988. 
DE CHIRICO, Giorgio, a cura di FAGIOLO, Maurizio. Il meccanismo del pensiero:

Crítica, polemica e autobiografia: 1911 - 1943. Torino: Giulio Einaudi, 1985.

DE FUSCO, Renato. História da arte contemporânea. Lisboa: Proença, 1988.

DE MICHELI, Mario. Las vanguardias artisticas del siglo XX. Madri: Aliança, 1966.

Dicionário brasileiro de artistas plásticos. Brasília: Instituto Nacional do Livro/MEC, 1973.

DUQUE, Gonzaga. Arte brasileira. Campinas: Mercado de Letras, s/d.

FABRIS, Annateresa, (org.). Modernidade e Modernismo no Brasil. Campinas: Mercado de Letras, 1994.

FABRIS, Annateresa. O Futurismo Paulista. São Paulo: Perspectiva, 1994. O Futurismo Paulista: hipóteses para a chegada da vanguarda no

Brasil. São Paulo: Perspectiva, 1993.

FER, Bryoni et. al. Realismo, Racionalismo, Surrealismo: a arte no entre-guerras. São

Paulo: Cosac \& Naify, 1998.

FOSSATI, Paolo. La pittura metafísica. Torino: Giulio Einaudi,1988. Storia dell'arte italiana. Torino: Giulio Einaudi, s/d. Valori Plastici. Torino: Giulio Einaudi, 1981.

FRANCASTEL, Pierre. Realidade Figurativa. São Paulo: Perspectiva, 1975. La figura y el lugar: el orden visual del Quatroccento. Venezuela:

Editorial Arte, 1969.

GATTO, Afonso. Carrà: tutta l'opera pittorica, v. I. Milano: Edizioni della Conchiglia, s/d. GLUSBERG, George. Retórica del arte latinoamericano. Buenos Aires: Nova Vision, s/d. GOMBRICH, E. H. História da arte. São Paulo: Círculo do livro, 1972.

GONÇALVES, Lisbeth R. Aldo Bonadei: o percurso de um pintor. São Paulo: Perspectiva, 1990. Sérgio Milliet, crítico de arte. São Paulo: EDUSP, 1992.

GUERRY, Liliane Cézanne et l'expression de l'espace. Paris: Flamarion, 1950.

HAUSER, Arnold. História da Literatura e da Arte, v. II. São Paulo: Mestre Jou, 1982.

KRAUS, Rosalind. The originality of avant guard and other modernst myths. Cambridge: The Mit. Press, 1997.

LAUDANA, Mayra. Raphael Galvez, 1907 - 1998. São Paulo: Momesso edições de elite, 1999.

LEITE, José Roberto Teixeira. Dicionário crítico da pintura no Brasil. Rio de Janeiro: Artlivre, 1988.

LEVEY, Michael. From Giotto to Cézanne: a concise history of painting. N.Y.: Thames 
\& Hudson, 1987.

LICHTENSTEIN, Jacqueline. A cor eloqüente. São Paulo: Siciliano, 1994.

LORAN, Erle. Cézanne’s composition. Berkeley: University of California Press, 1963.

LOURENÇO, Marília Cecília F. Operários da Modernidade. São Paulo: Hucitec/EDUSP, 1995.

Maioridade do moderno em São Paulo, anos 30 e 40. São

Paulo: FAU/USP, 1990. (tese de doutorado).

LOUZADA, JULIO. Artes Plásticas no Brasil, seus mercados, seus leilões, 1987, v. II. São

Paulo: Inter/Arte/Brasil, 1987.

Artes Plásticas no Brasil, seus mercados seus leilões, 1989, v. III. São

Paulo: Inter/arte/Brasil, 1989.

MACHADO, Lourival G. Retrato da arte moderna no Brasil. São Paulo: Dep. De Cultura, 1948.

MALTESE, Corrado. Storia dell' arte in Itália: 1785 - 1943. Torino: Einaudi, 1992.

MARTINS, Luiz. A pintura moderna no Brasil. Rio de Janeiro: Schimidt, 1937.

MEDINA, Joyce. Cézanne and modernism: the poetics of painting. New York: State

University of N.Y. Press, s/d.

MILLIET, Sérgio. Diário crítico de Sérgio Milliet. São Paulo: Martins Fontes, 1981. Marginalidade da pintura moderna. São Paulo: Dep. De Cultura, 1942. Pintores e pinturas. São Paulo: Liv. Martins, 1942.

MOTTA, Carlos G. Ideologia da cultura brasileira. São Paulo: Ática, 1977.

NAVES, Rodrigo. A forma difícil. São Paulo: Ática, 1996.

NOCHLIN, Linda. Realism. New York/Baltimore: Penguin Books Inc., 1971.

PEDROSA, Mário. Acadêmicos e modernos. Rio de Janeiro: Paz e Terra, 1977.

Dos murais de Portinari aos espaços de Brasília. São Paulo: Perspectiva,

1974.

PEVSNER, Nicolaus. Las academias del'arte: pasado y presente. Madrid: Catedra, 1982.

PRADO, Yan de Almeida. A grande semana de arte moderna. São Paulo: EDART, 1976.

REVILLA, Federico. Diccionario de Iconografía y Simbologia. Madri: Cátedra, 1999.

RIBEIRO, Niura. Rossi Osir: artista e idealizador cultural.. SãoPaulo, ECA/USP, 1995.

(Dissertação de mestrado).

SCHAPIRO, Meyer. Modern Art: $19^{\text {th }}$ and $20^{\text {th }}$ centuries. N. Y.: George Brasiller, 1974. Cézanne. N.Y.: Harry n. Abrams Inc., s/d.

SHIFF, Richard. Cézanne and the end of Impressionism: a study of the theory, technique and 
Critical evaluation of modern art. Chicago: Chicago University Press, 2984.

TARASANTCHI, Ruth S. Pintores paisagistas em São Paulo (1890-1920). São Paulo:

ECA/USP, 1986.(tese de doutorado).

TASSINARI, Humberto. O espaço moderno. São Paulo: Cosac \& Naify, 2001.

TELES, Mendonça G. Vanguarda européia e Modernismo brasileiro. São Paulo: Vozes, 1999.

VENTURI, Lionello. A pintura italiana: de Caravaggio a Modigliani. Lisboa: Estúdios Cor, 1987.

VERDI, Richard. Cézanne. N.Y.: Thames \& Hudson, 1984.

WALLIS, Brian. Art after modernism: rethinking representation. N. Y.: The New Museum of Contemporary Art, 1989.

WOLLHEIM, Richard. Painting as an Art. N.Y.: Thames \& Hudson, 1994.

ZANINI, Walter. História geral da arte no Brasil, v II. São Paulo: Inst. Walter M. Sales, 1983.

A arte no Brasil nas décadas de 30 e 40. São Paulo: Nobel, s/d.

ZILIO, Carlos. A querela do Brasil. Rio de Janeiro: FUNARTE, 1982.

JORNAIS, ARTIGOS E ENSSAIOS.

“Anita Malfati, a mártir do Modernismo”. O Estado de S. Paulo. São Paulo, 13/12/1969.

CARVALHO, Mário C. "Bye-bye província”. Folha de S. Paulo: Especial Bienal 50 anos, p. $15,20 / 05 / 2001$.

CONSOLI, T. Chiesa di San Giuseppe. http:/www.Scordia nell Sito della Chiesa di San

Giuseppe.com.it(Scordia della Província), s/d.

COUTO, José G. “Confissões do Modernismo”. Folha de S. Paulo, Mais, p. 22, 09/04/2000.

CALVESI, Maurizio. “Un sodalizio nel nome di Piero”. Ensaio, sem referências.

DELL'ARCO, Maurizio. “The World in a Bottle.” Ensaio, sem referências.

GRILLO, Cristina. “Guignard ganha retrospectiva no Rio". Folha de S. Paulo, Ilustrada.

São Paulo, p. 3, 30/05/2000.

GUERREIRO, Walter de Queiroz. Modernismo até certo ponto http:/www.na.com.br(anexo Joinville), 07/07/99.

“I Salão de Artes de Imigração e Integração". Jornal do Imigrante. São Paulo, p.8, 15/8/1990. LIMA, Leo. Di Cavalcanti: o poeta pictórico do populário carioca.http:/www.cenaurbana. 
Com.Br/cultura/arte/di [Cultura: Arte: Cena Urbana], s/d.

LOPES, Telê Porto Ancona. “Os modernistas de São Paulo e o circo". $\underline{\text { O Estado de S. }}$

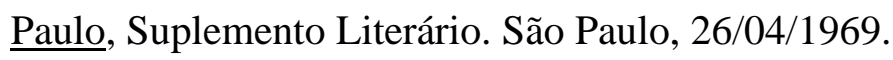

MAMMI, Lorenzo. "Linhas de Nossa Arte”. Folha de S. Paulo, Especial de Resenhas. São Paulo, p.12, 12/12/1998.

PEDROSA, Mário. “Giorgio Morandi”. Folha de S. Paulo, Mais. São Paulo, p.10, 16/04/00.

ROUANET, Sérgio. "A morte e o renascimento das utopias". Folha de S. Paulo, Mais. São

Paulo, p. 16, 25/06/2000.

\section{REVISTAS}

CHIARELLI, Tadeu. “O Novecento e a arte brasileira”. Revista de Italianística. São Paulo, Faculdade de Filosofia, Letras e Ciências Humanas da USP, número 3, 1995.

FABRIS, Annateresa. "A crítica modernista e a cultura do ecletismo". Revista de

Italianística. São Paulo, FFLCH/USP, número 3, 1995.

FRANCODOLMI. "Morandi: storia e leggenda". Grafis, sem mais referências.

HERKENHOFF, Paulo. “Brasil (es)”. Lapiz. Madri, jul./set. de 1997.

LUSARETA, Pilar de. “Clássicos e modernos de la pintura brasileña actual”. El Hogar. Argentina, 24, maio, de 1935.

SOARES, Flávia. "O artista e sua obra". Revista Mercado de Arte, sem mais referências.

NAVES, Rodrigo. “O complexo e o Confuso”. Novos Estudos, número 18, Set. de 1987.

TARASANTICH, Ruth. "O paisagismo: contribuição dos italianos à visão brasileira."

Revista de Italianística. São Paulo, FFLCH/USP, número 3, 1995. 


\section{CATÁlOGOS}

A Pinacoteca do Estado. São Paulo: Banco Safra, 1994.

ALMEIDA, Paulo Mendes de. A Família Artística Paulista, trinta anos depois. São Paulo: Auditório Itália, 1967.

PAGÉ, Suzanne. Anées 30 em Europe: 1929 - 1939. Paris: Musée d'Art Moderne de la Ville De Paris/Flammarion, 1997.

Arte in Itália: da valori plastici a Corrente. São Paulo: Pinacotecado Estado, 1998.

Desenovevinte, uma virada no século. São Paulo: Pinacoteca do Estado/ DEMA, 1986.

BARATA, Mário. Hugo Adami. São Paulo: MAM, 1986.

GOUVEA, Renato M. Hugo Adami. São Paulo: Renato Magalhães Gouvea, escritório de arte, 1993.

Morandi. São Paulo: União Latina e Museu de Arte de S.P., 1997.

EWALDO, Cecília e MONTEIRO, Paulo. Morandi no Brasil. São Paulo: Pirelli, 1995.

PARROCHI, Antonio. I Macchiaioli: 55 dipinti nelle colezione private. Florença, 1984.

Os Salões. São Paulo: Museu Lasar Segall, 1976.

Três pioneiros nos tempos dos Salões. São Paulo: Museu Lasar Segall, 1980.

\section{DEPOIMENTOS}

CABRAL, Antônio Hélio. Entrevista de Hugo Adami a Antônio Hélio Cabral. São Paulo, Museu Lasar Segall, São Paulo, 1976.

KUNIGK, Maria Cecília e PAIM, Ivana Soares. Entrevista de Hugo Adami. São Paulo, Outubro de 1997.

PAIM, Ivana S. Entrevista de Adriana Adami, sobrinha do artista à autora, em sua residência, São Paulo, 2002.

.Entrevista de Hugo Adami à autora. São Paulo, dezembro/1999. .Entrevista do Marchand Joaquim Nunes à autora. São Paulo, abril/2002. Entrevista do Prof. Dr. Luciano Migliaccio à autora. São Paulo, FAU/USP, abril/2001.

Entrevista da Profa. Dra. Mayra Laudana à autora. São Paulo, IEB/USP, junho/2001. 
. Entrevista do colecionador Roberto Frizzo à autora. São Paulo, março/2001.

Entrevista de Rosa Adami, filha adotiva do artista à autora. São Paulo, agosto/2000.

. Entrevista de Valéria Adami, sobrinha do artista Valéria Adami. São

Paulo, dezembro de 1999. 


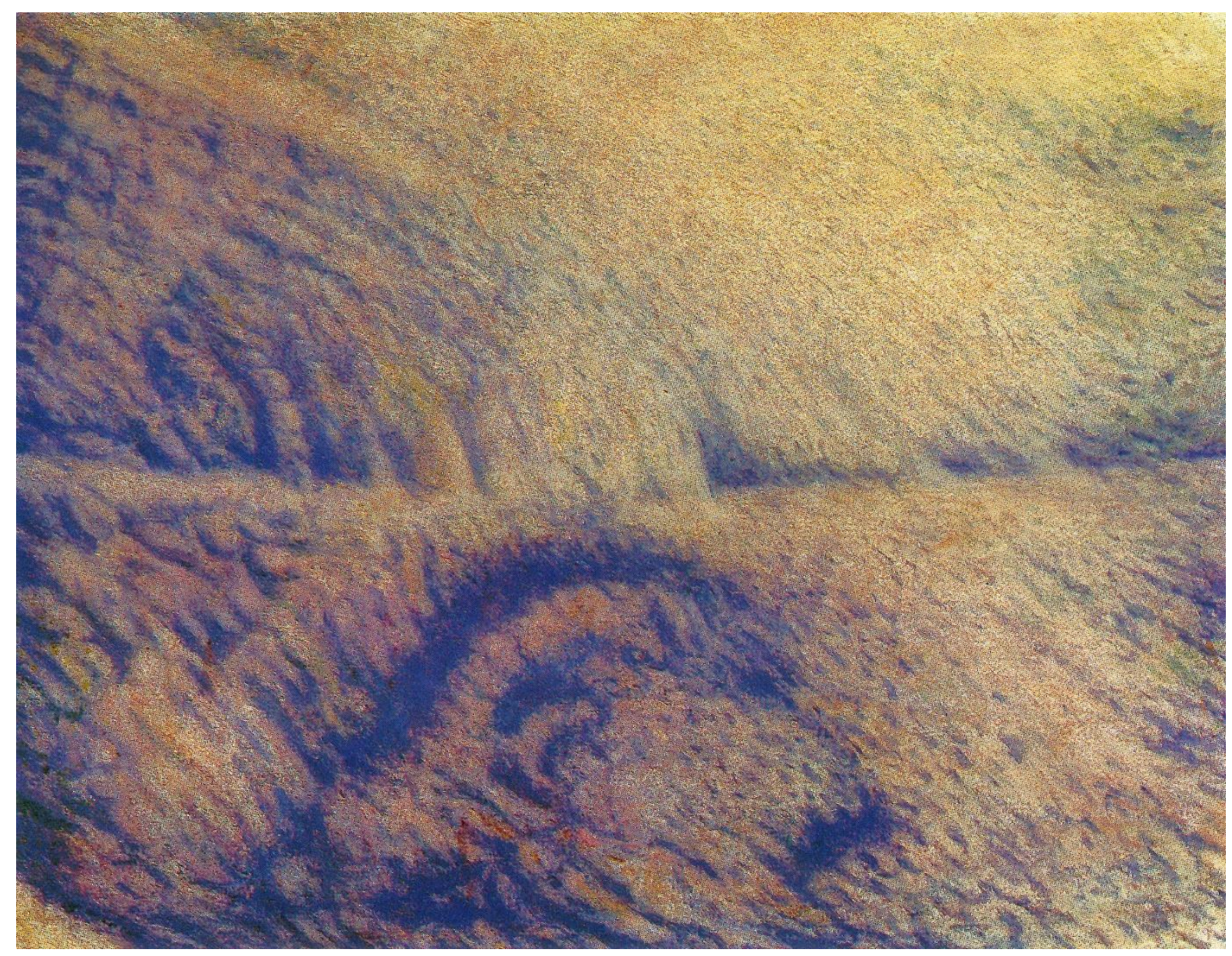

1 - Hugo Adami, Paisagem, anos 80;

50 x $60 \mathrm{~cm}$, óleo sobre tela. Paradeiro ignorado. 


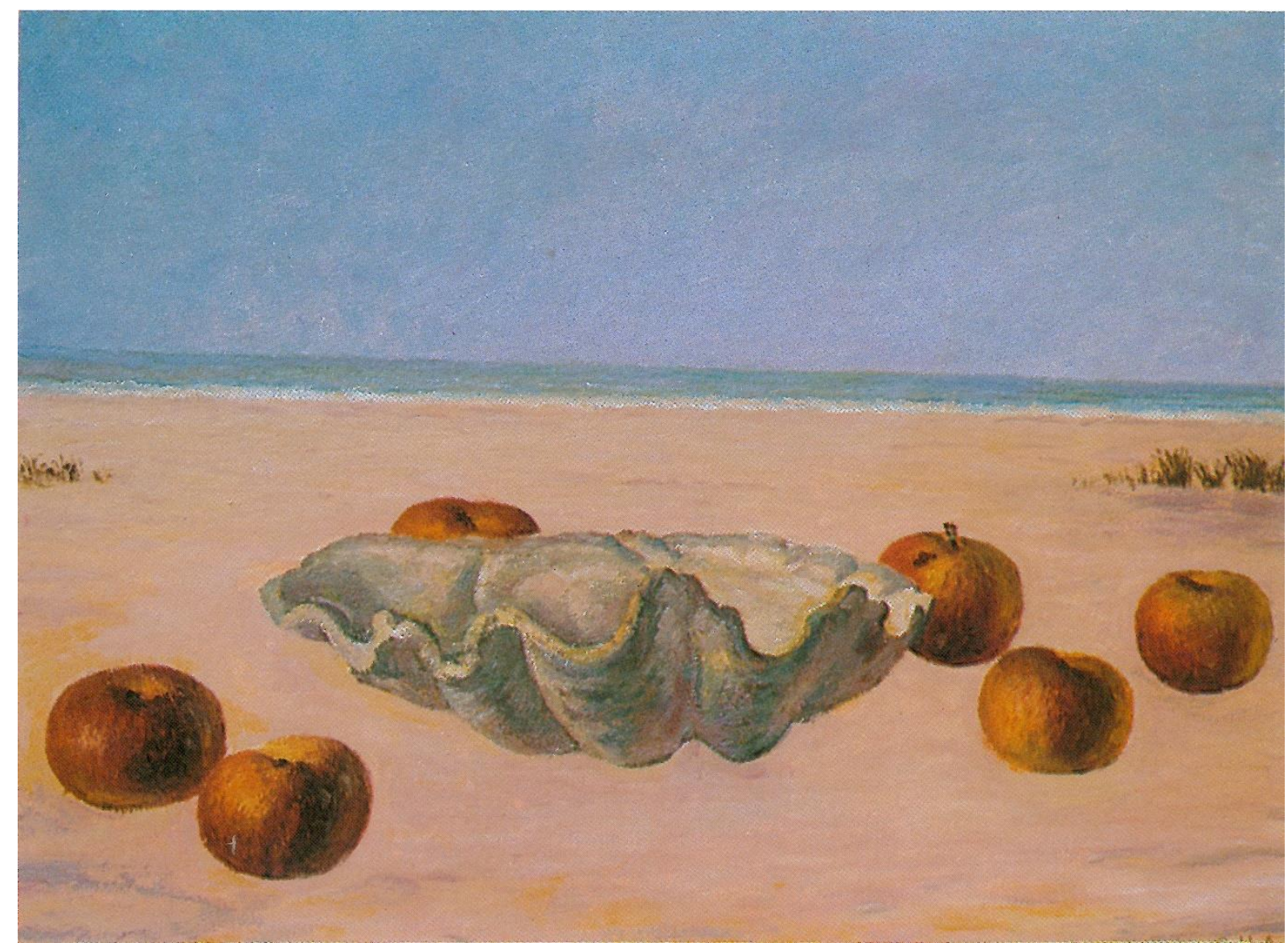

2 - Hugo Adami, Natureza-Morta na Praia, 1982;

50 x 60 cm, óleo sobre tela. Paradeiro ignorado. 


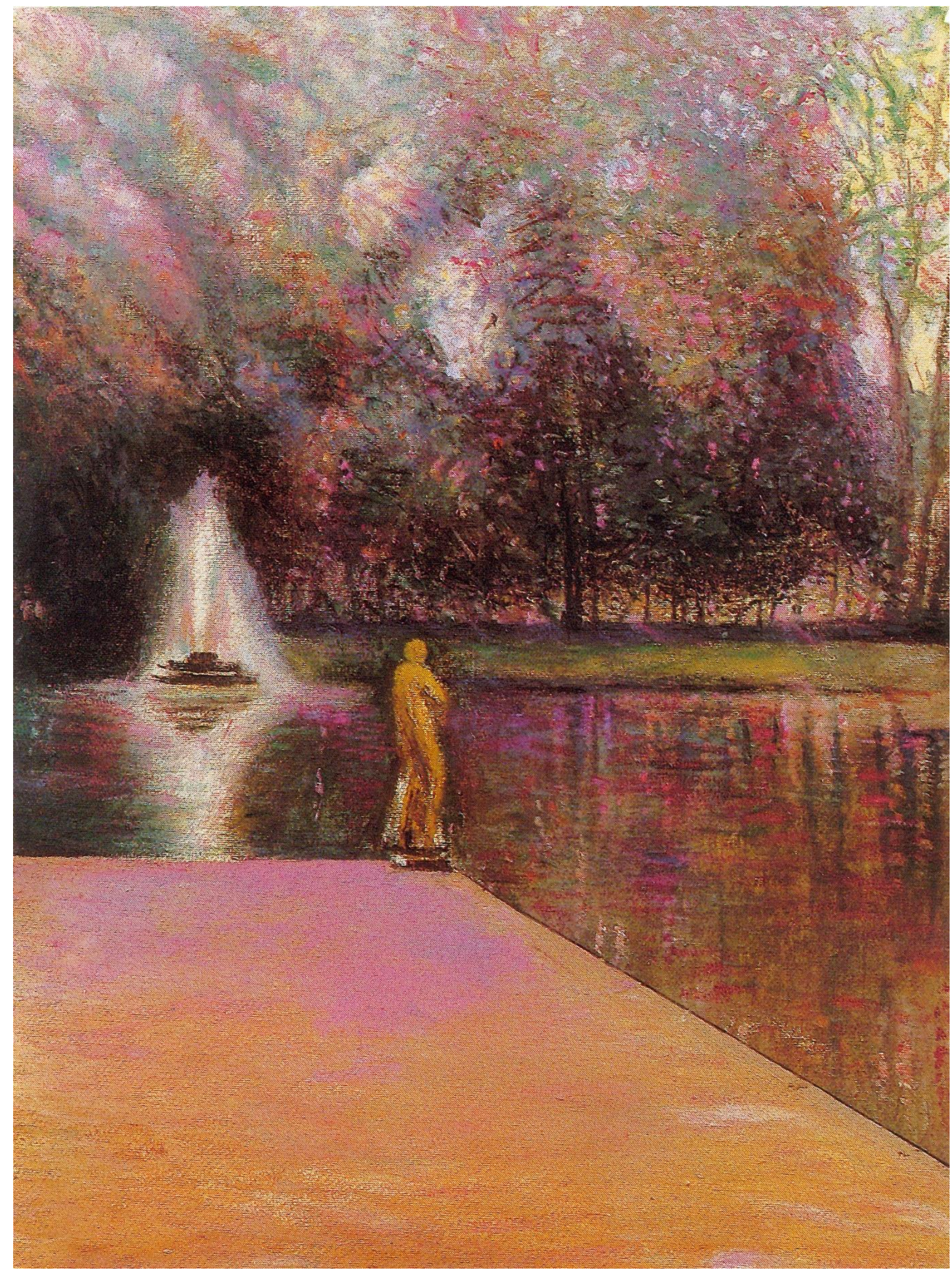

3 - Hugo Adami, Jardim da Luz, anos 80;

73 x 54 cm, óleo sobre tela, coleção Geraldo Modesto. 


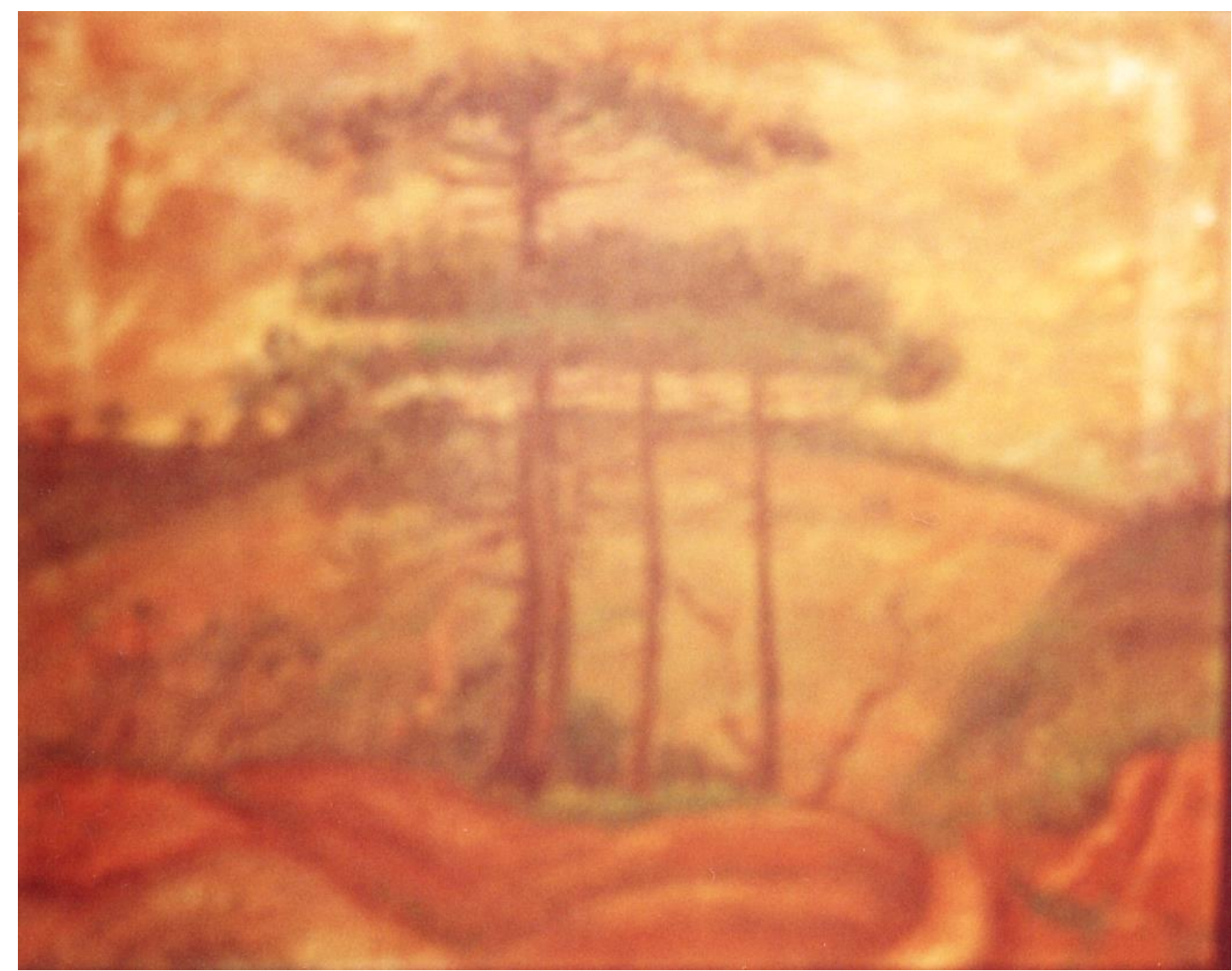

4 - Hugo Adami, Campos do Jordão, 1975;

39,2 x 49,5 cm, óleo sobre tela. Escritório de Arte Joaquim Nunes. 


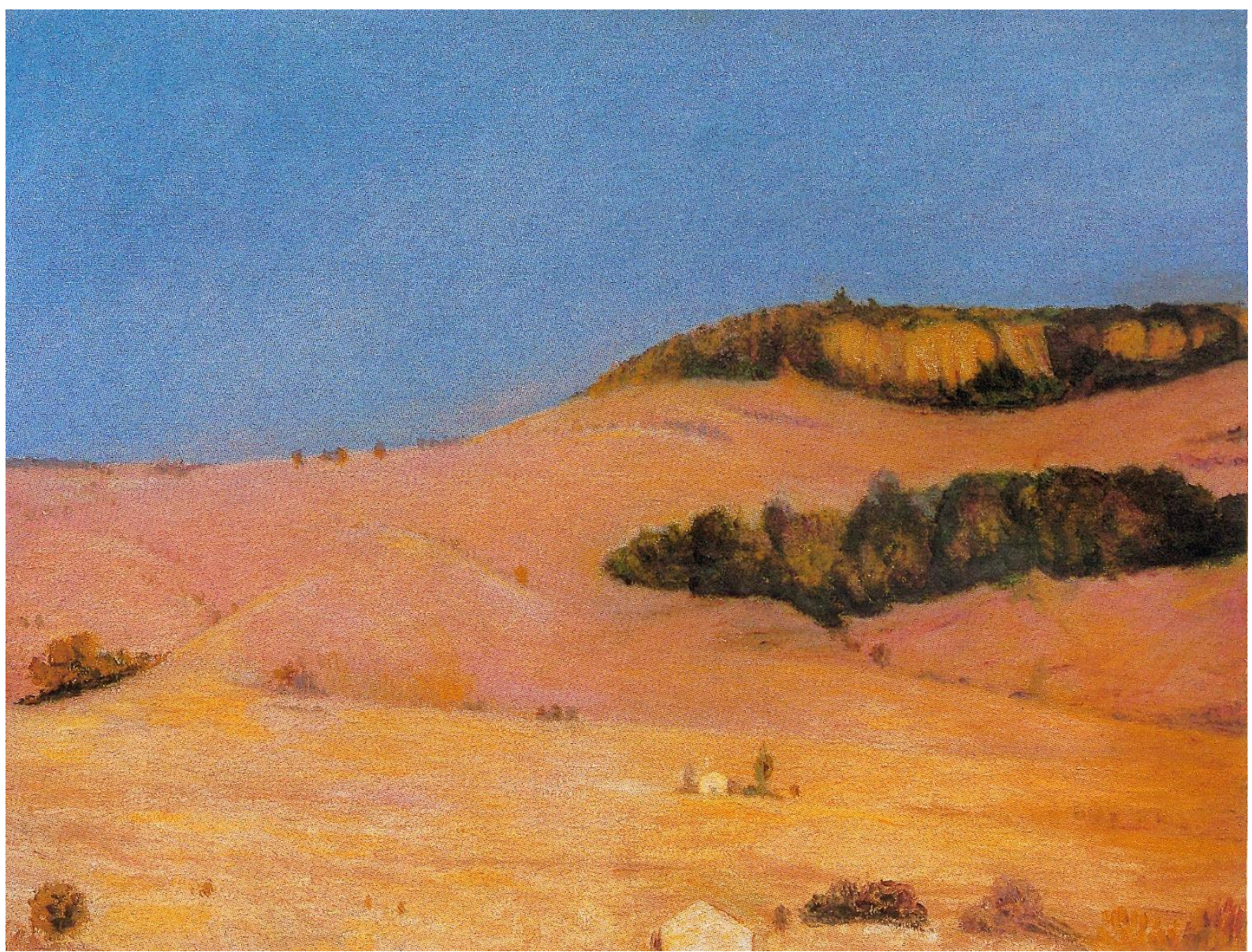

5 - Hugo Adami, Paisagem, anos 80;

50 x 60 cm, óleo sobre tela. Paradeiro ignorado. 


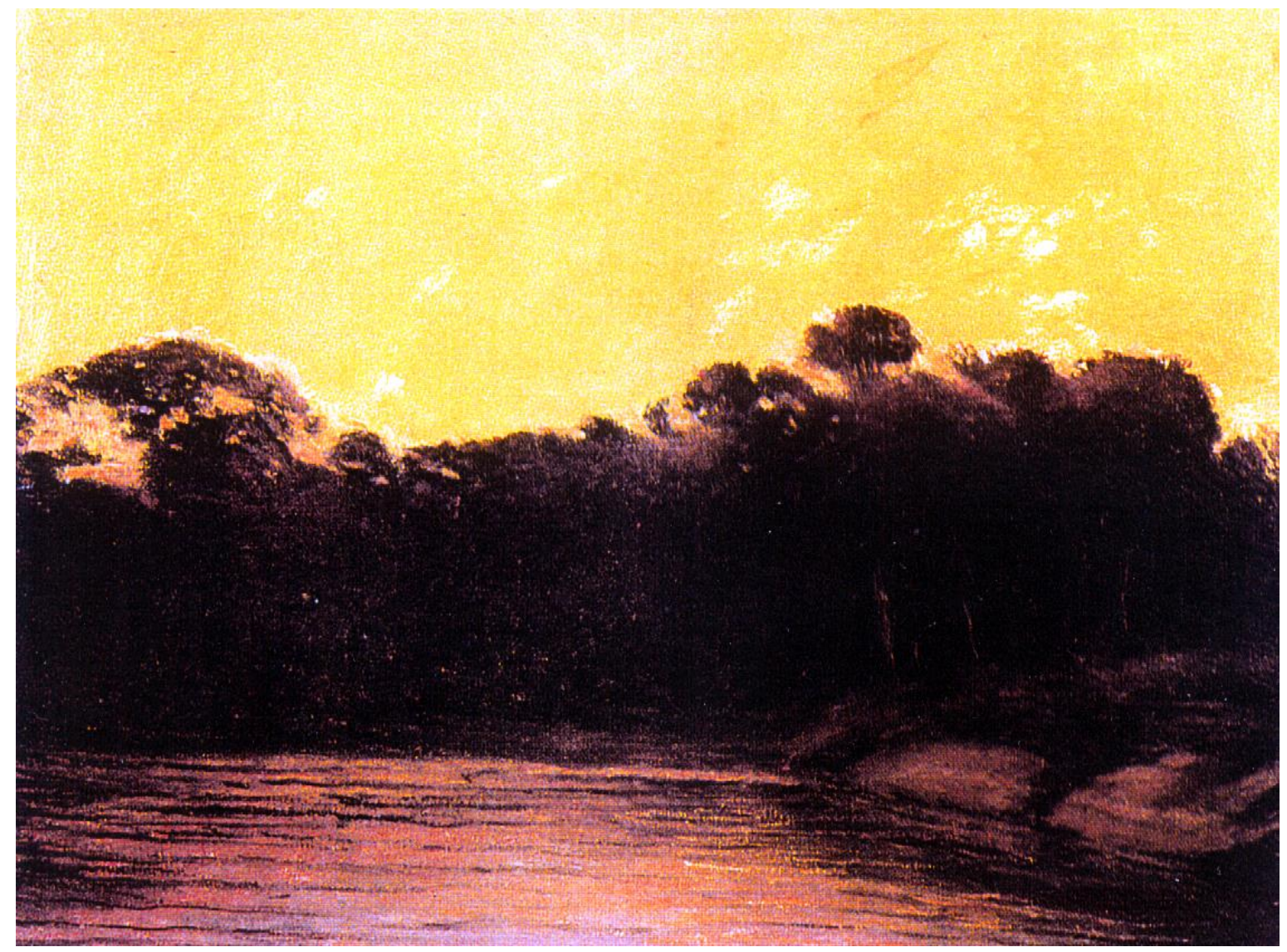

6 - Hugo Adami, Paisagem, anos 90;

50 x 60 cm, óleo sobre tela. Coleção Rosa Adami. 


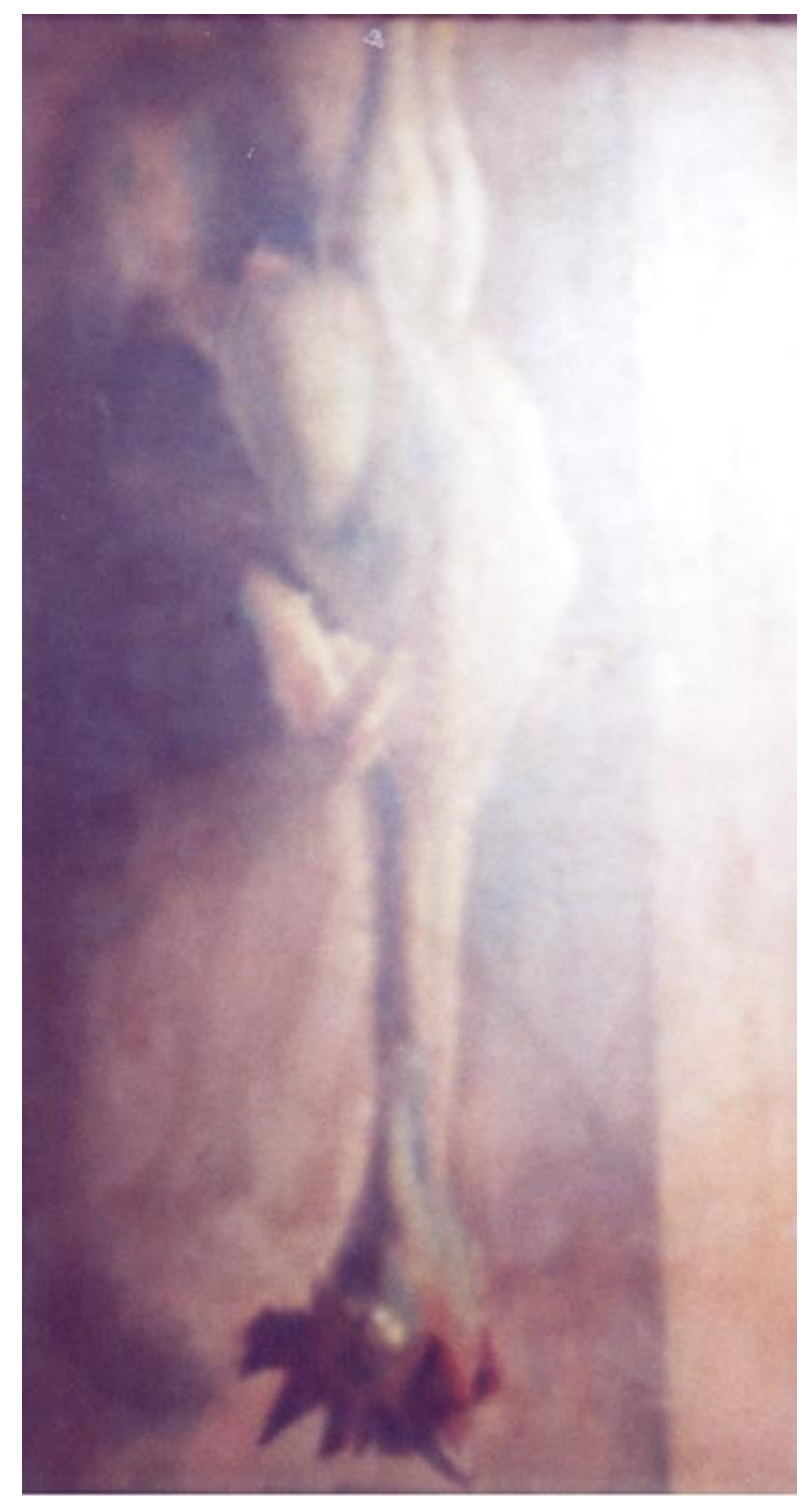

7 - Hugo Adami, Frango, 1916;

40 x 12 cm, óleo sobre tela. São Paulo, coleção Bellkiss Barioni. 


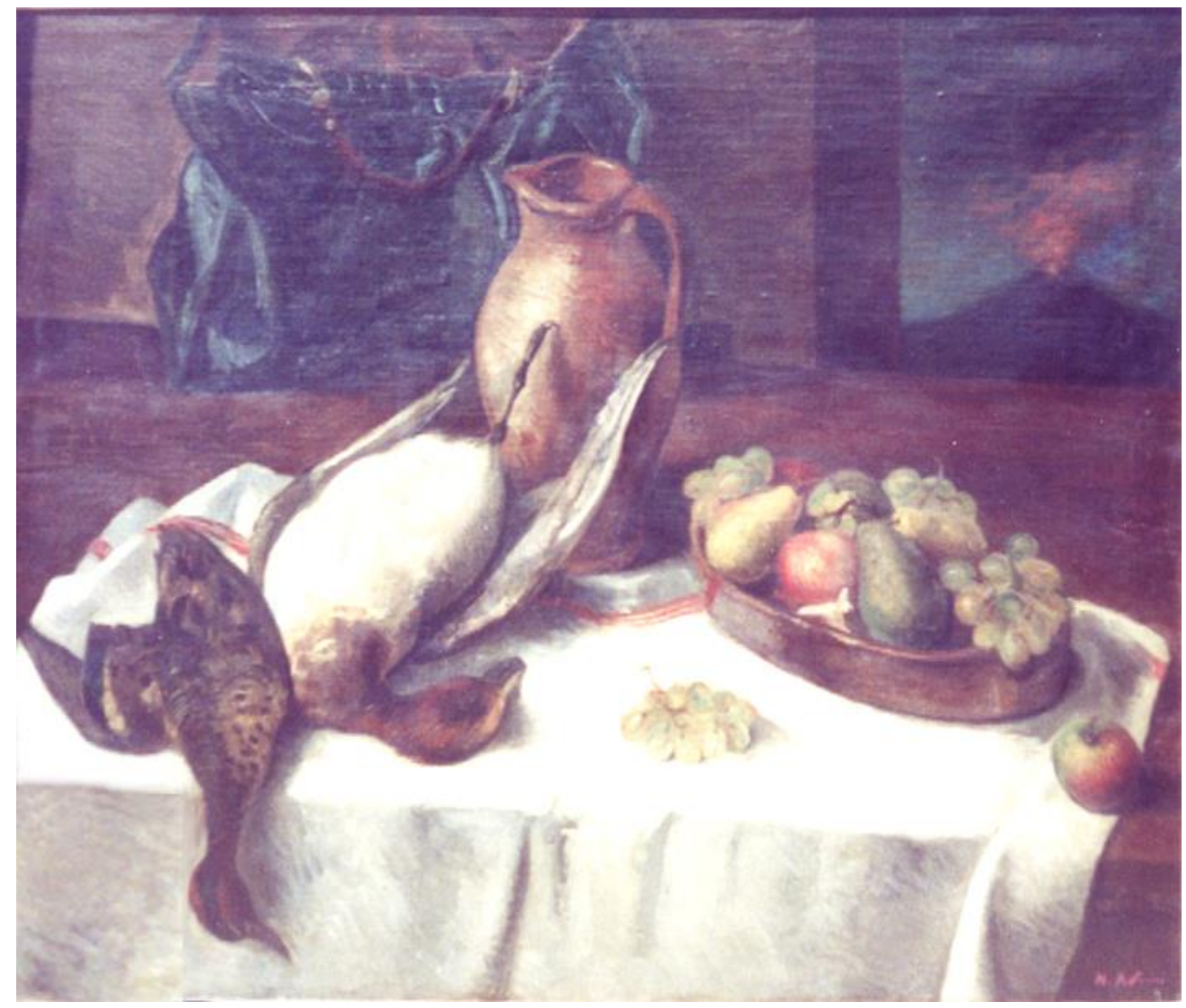

8 - Hugo Adami, Natureza-Morta com Faisões, 1932;

70 x 80 cm, óleo sobre tela. São Paulo, coleção Geraldo Modesto. 


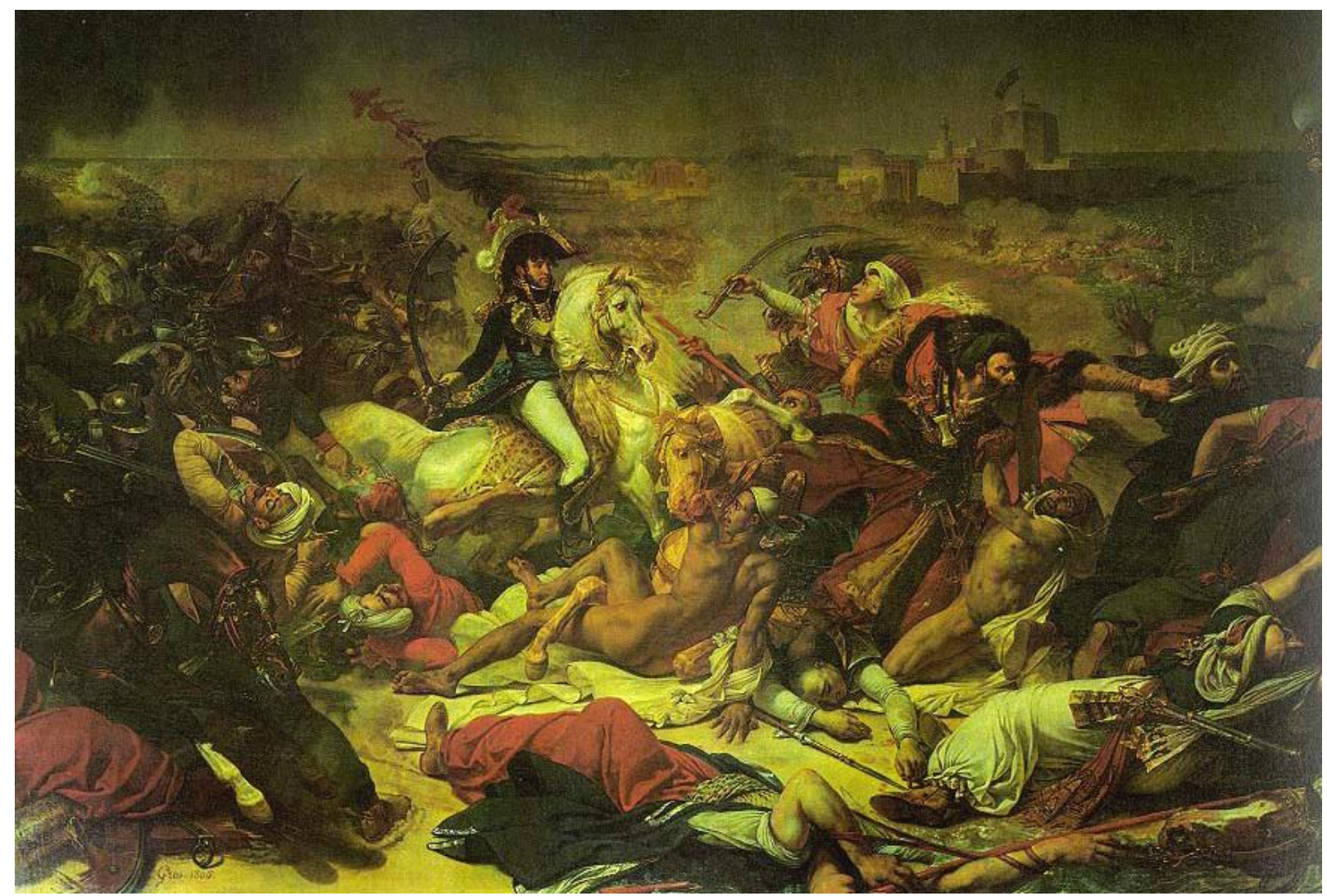

9 - Antoine Jean Gros, A Batalha de Aboukir, 1806;

578 x 968 cm, óleo sobre tela. Versalhes, Museu Nacional do Castelo. 


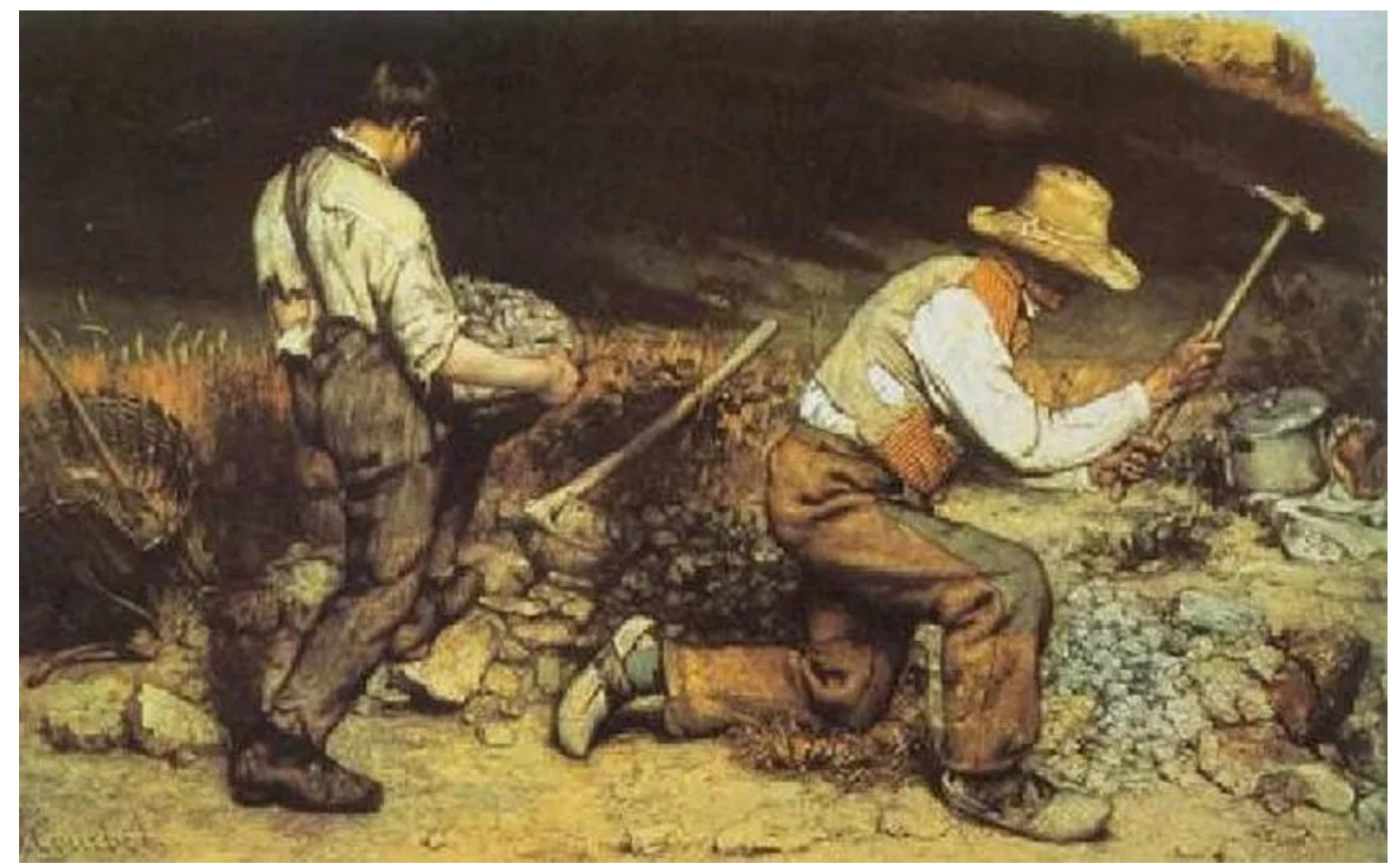

10 - Gustave Courbet, Britadores de Pedra, 1849;

159 x 259 cm, óleo sobre tela. Dresdem, Gemaldegalerie Neue Meister. 


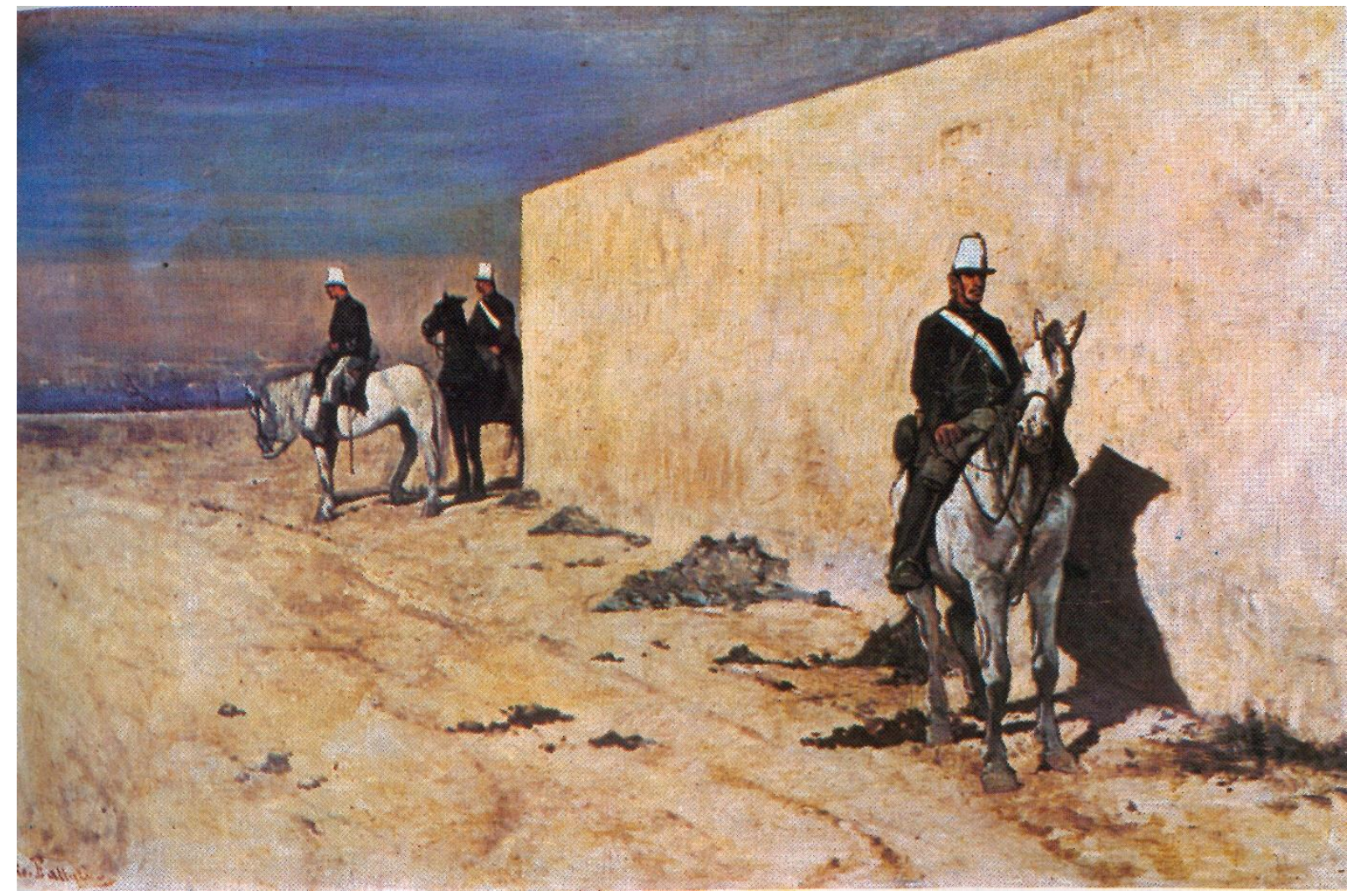

11 - Giovanni Fattori, De Sentinela, 1870;

37 x 56 cm, óleo sobre madeira. Valdagno, coleção Marzotto. 


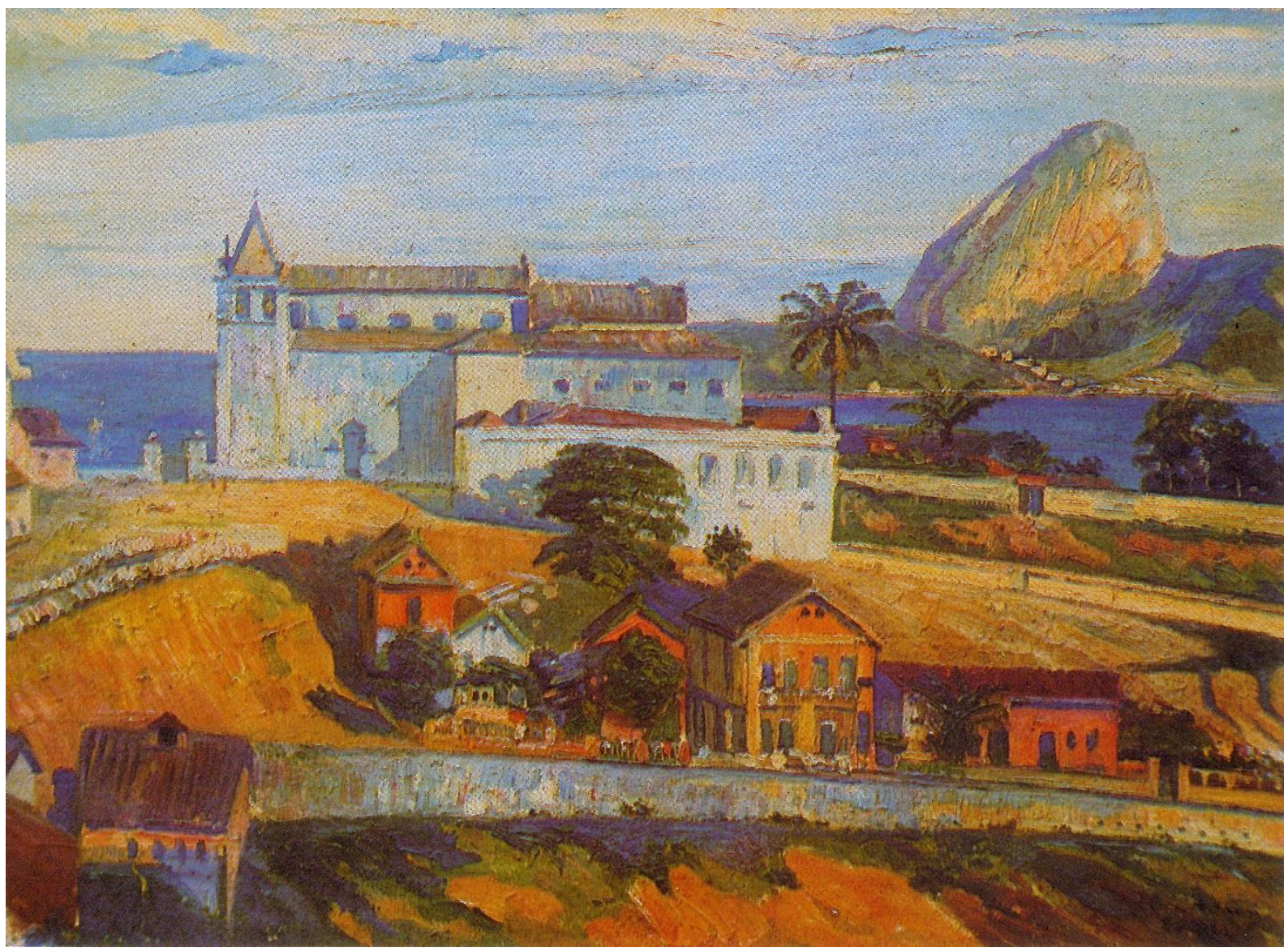

12 - Hugo Adami, Morro do Castelo, 1921;

57 x 73 cm, óleo sobre tela. São Paulo, coleção Lia Schultz. 


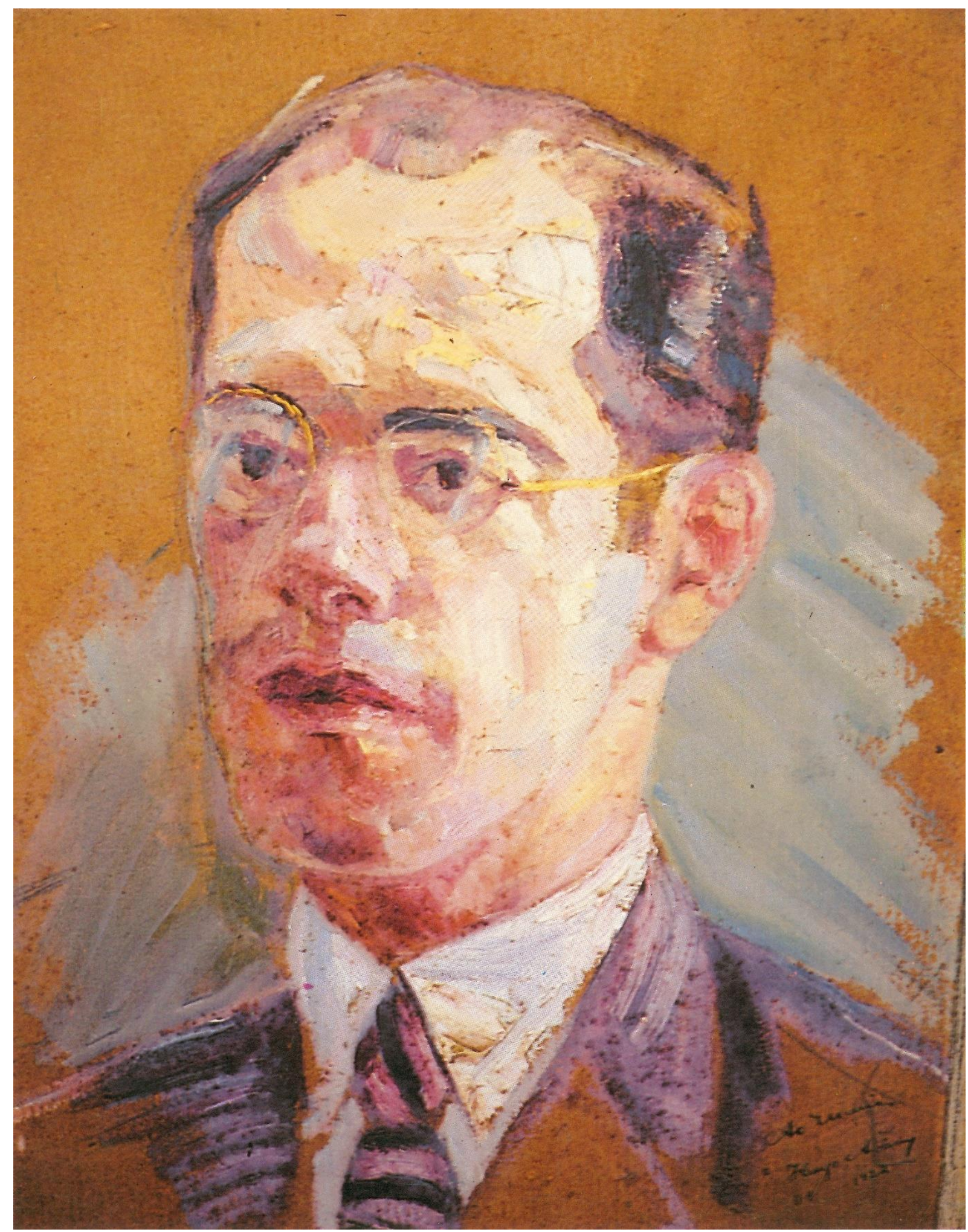

13 - Hugo Adami, Retrato de Mário de Andrade, 1922;

45,5 x 36 cm, óleo sobre tela. São Paulo, Instituto de Estudos Brasileiros da USP. 


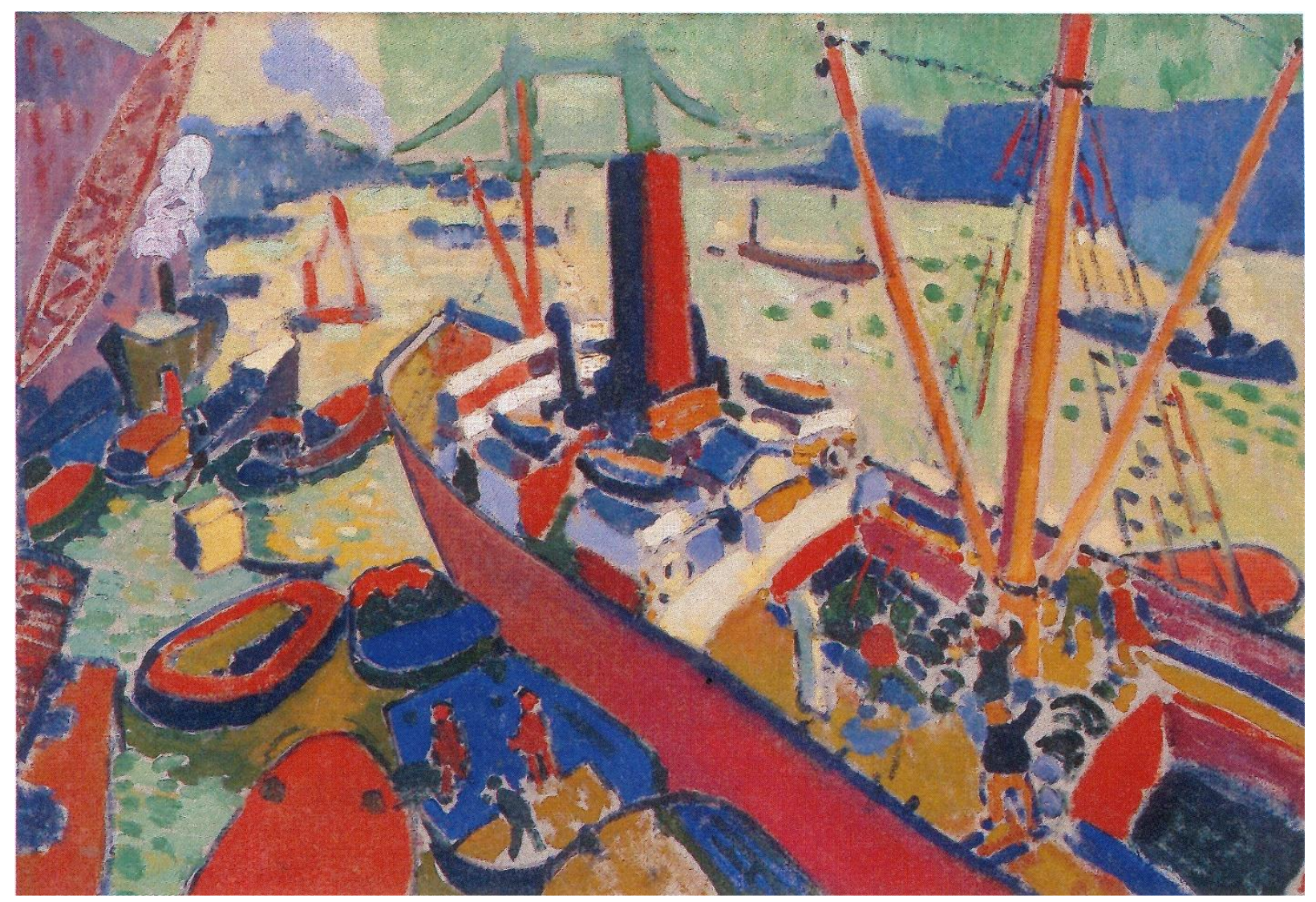

14 - André Derain, A Piscina de Londres, 1906;

66 x 99 cm, óleo sobre tela. Londres, Tate Gallery. 


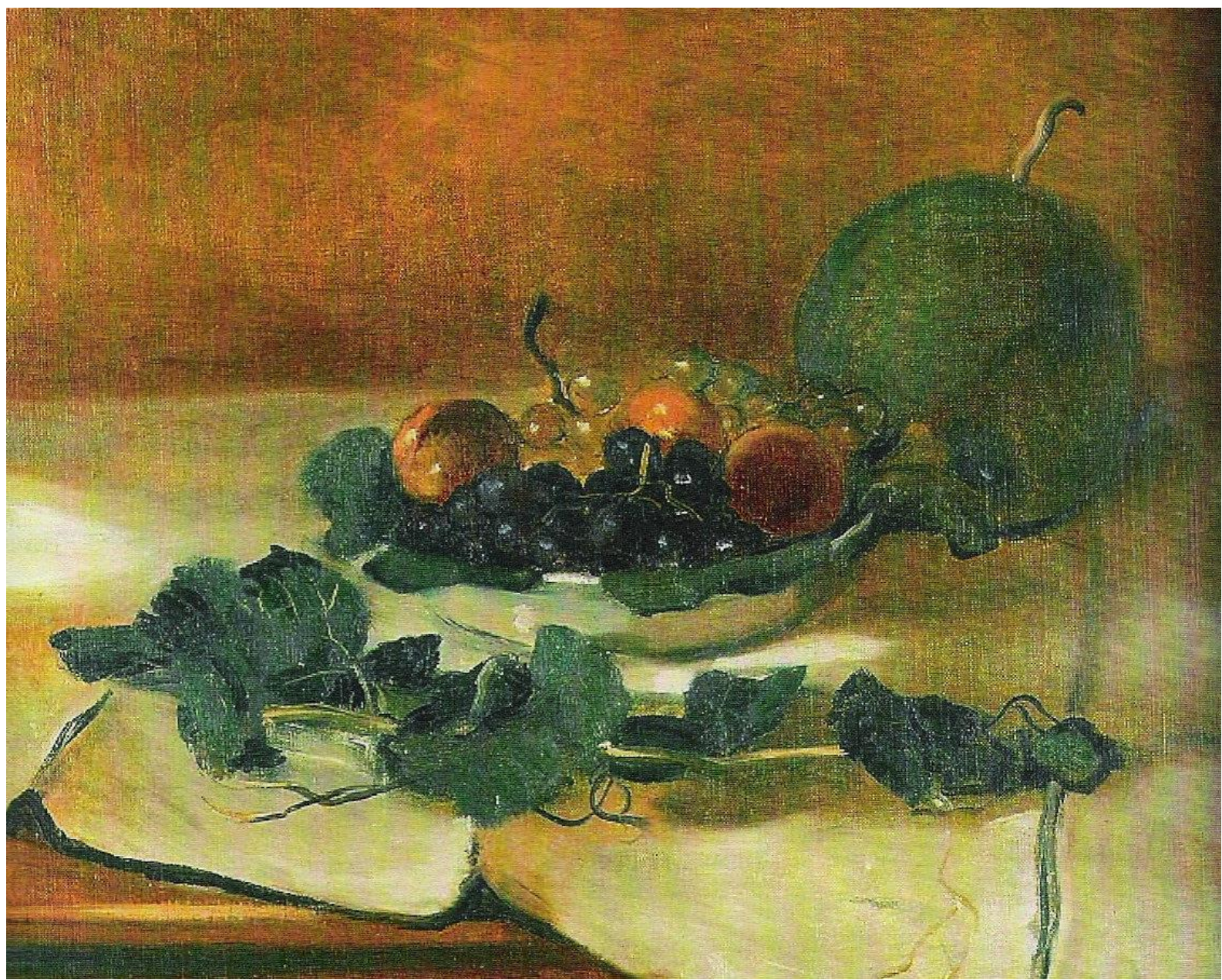

15 - André Derain, Melão e Uvas, 1927;

50 x $58 \mathrm{~cm}$, óleo sobre tela. Paris, Museu Nacional da Orangerie, coleção Jean Walter e Paul Guillaume. 


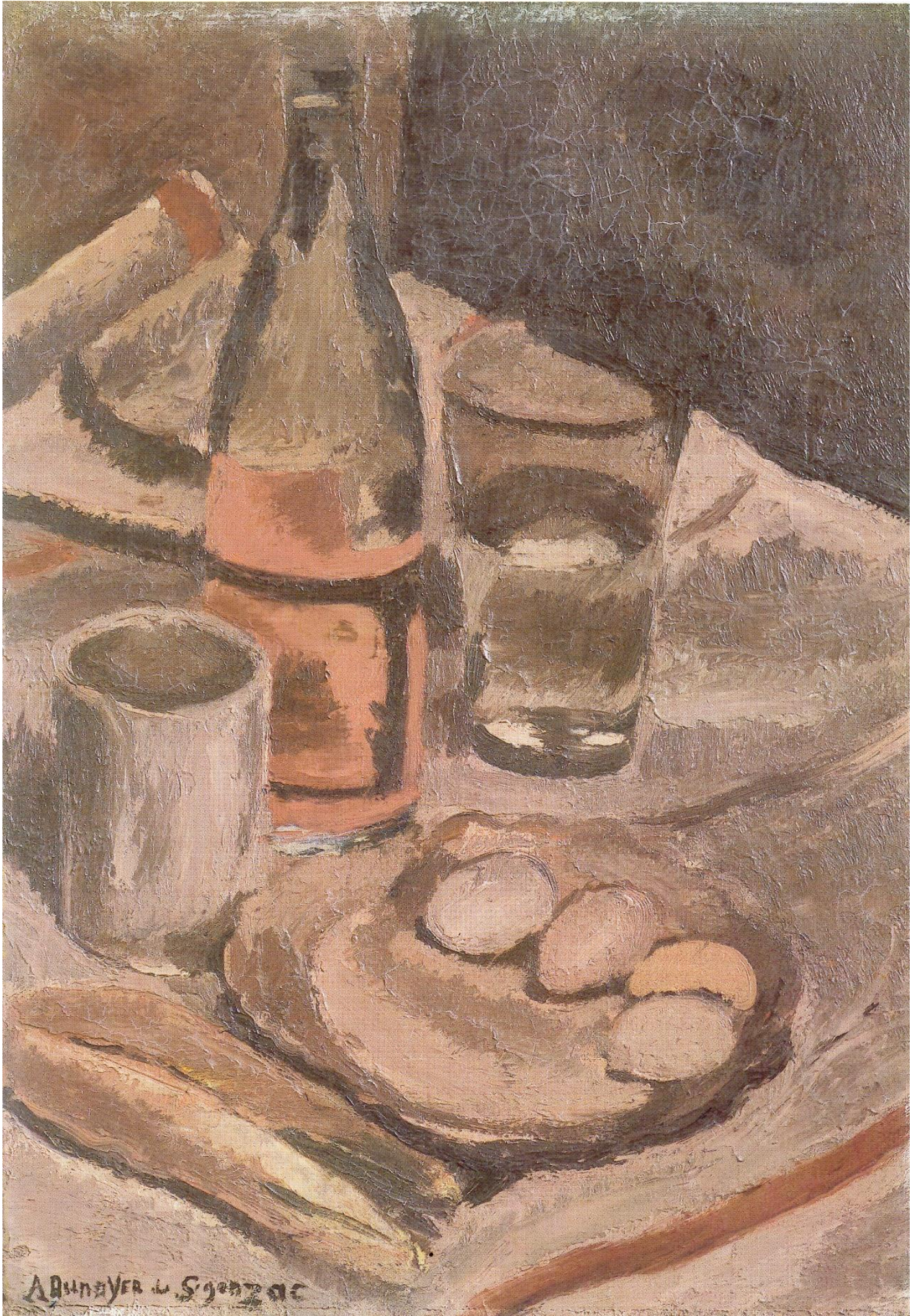

16 - André de Segonzac, Natureza-Morta com Ovos, 1923;

59 x 38 cm, óleo sobre tela. Londres, Courtauld Institute Galleries. 


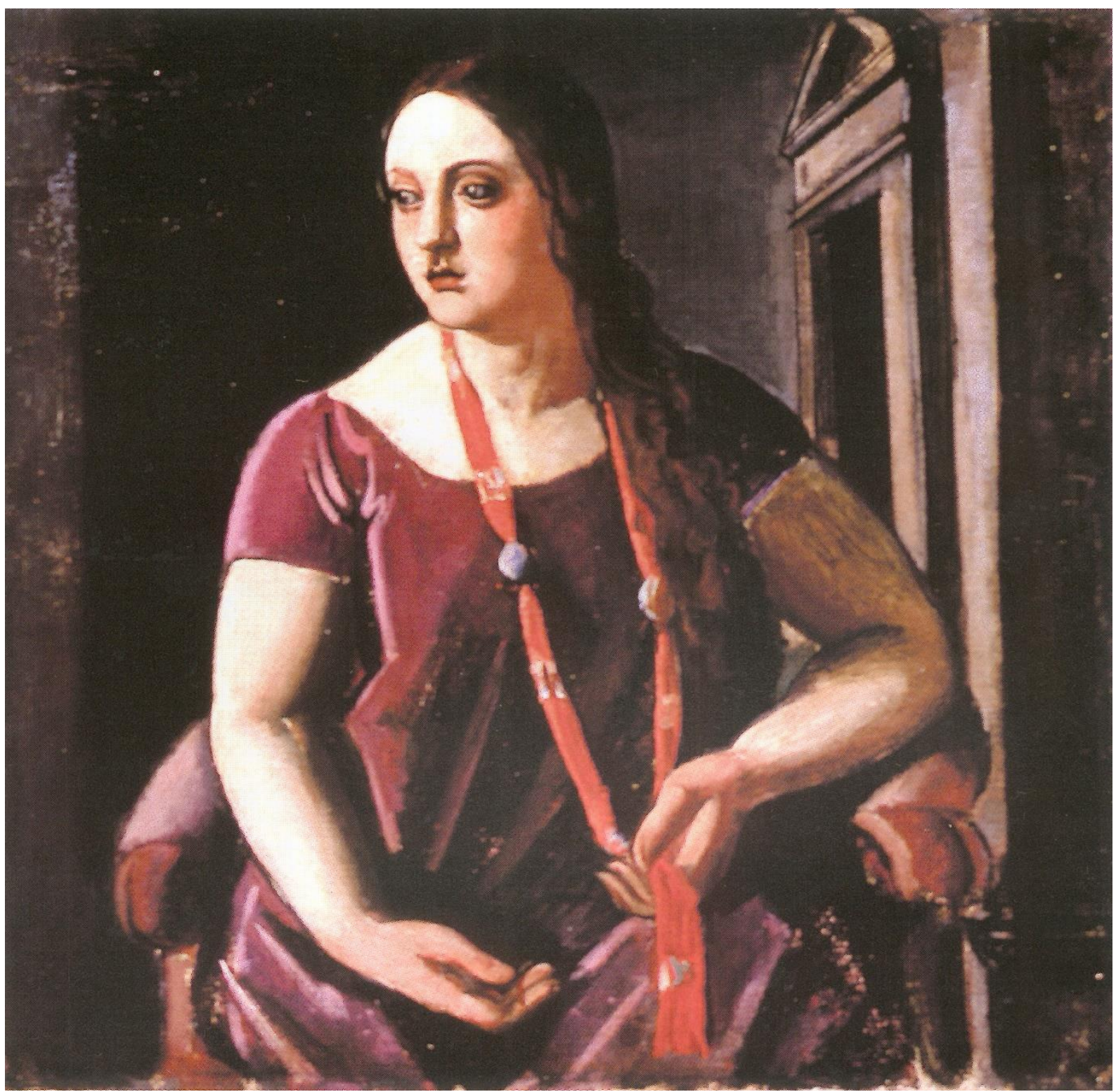

17 - Achile Funi, A Adivinha, 1924;

45,7 x 45,8 cm, óleo sobre madeira. São Paulo, Museu de Arte Contemporânea da USP. 


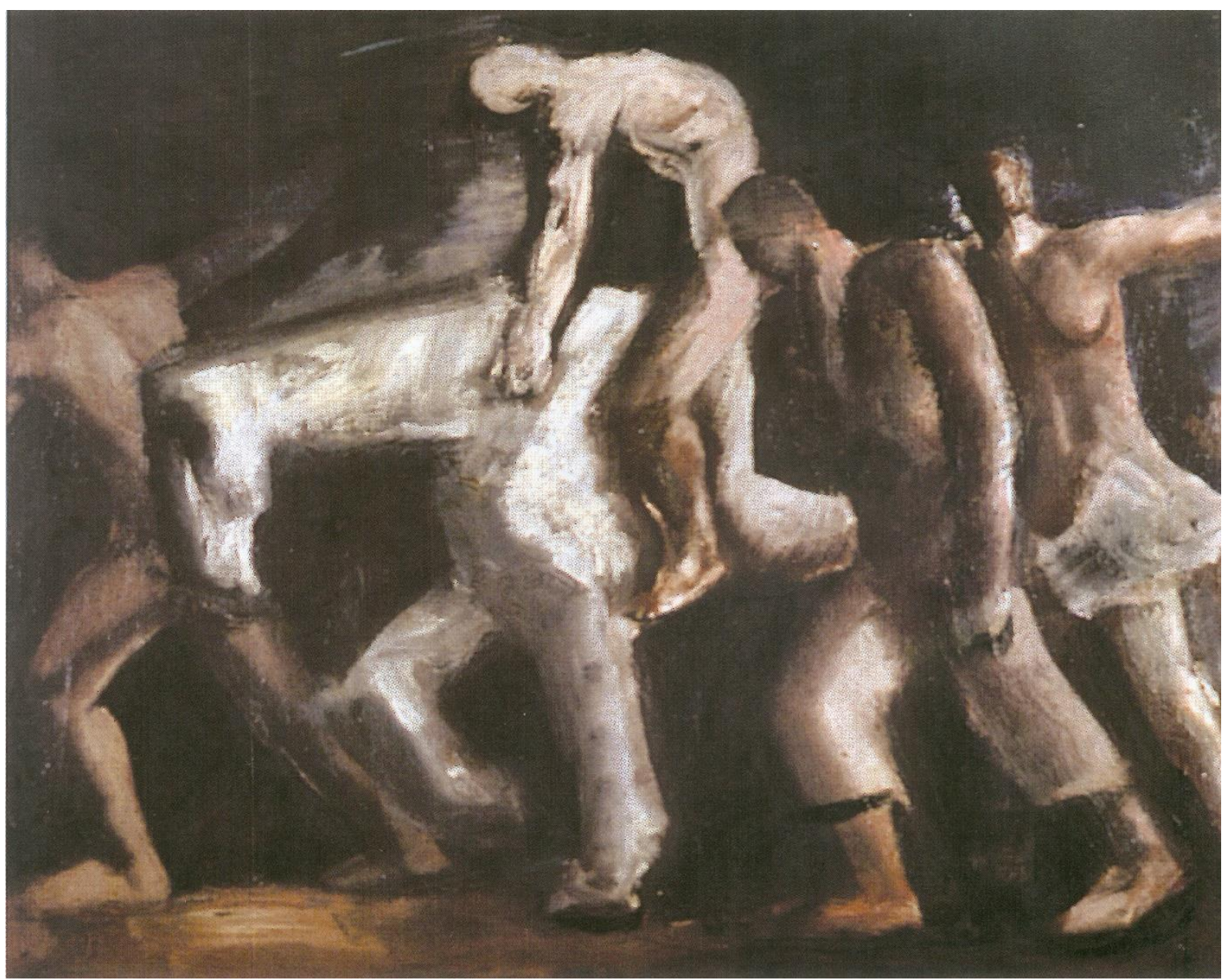

18 - Mário Sironi, Os Emigrantes, 1930;

68,8 x 79,2 cm, óleo sobre madeira. São Paulo, Museu de Arte Contemporânea da USP. 


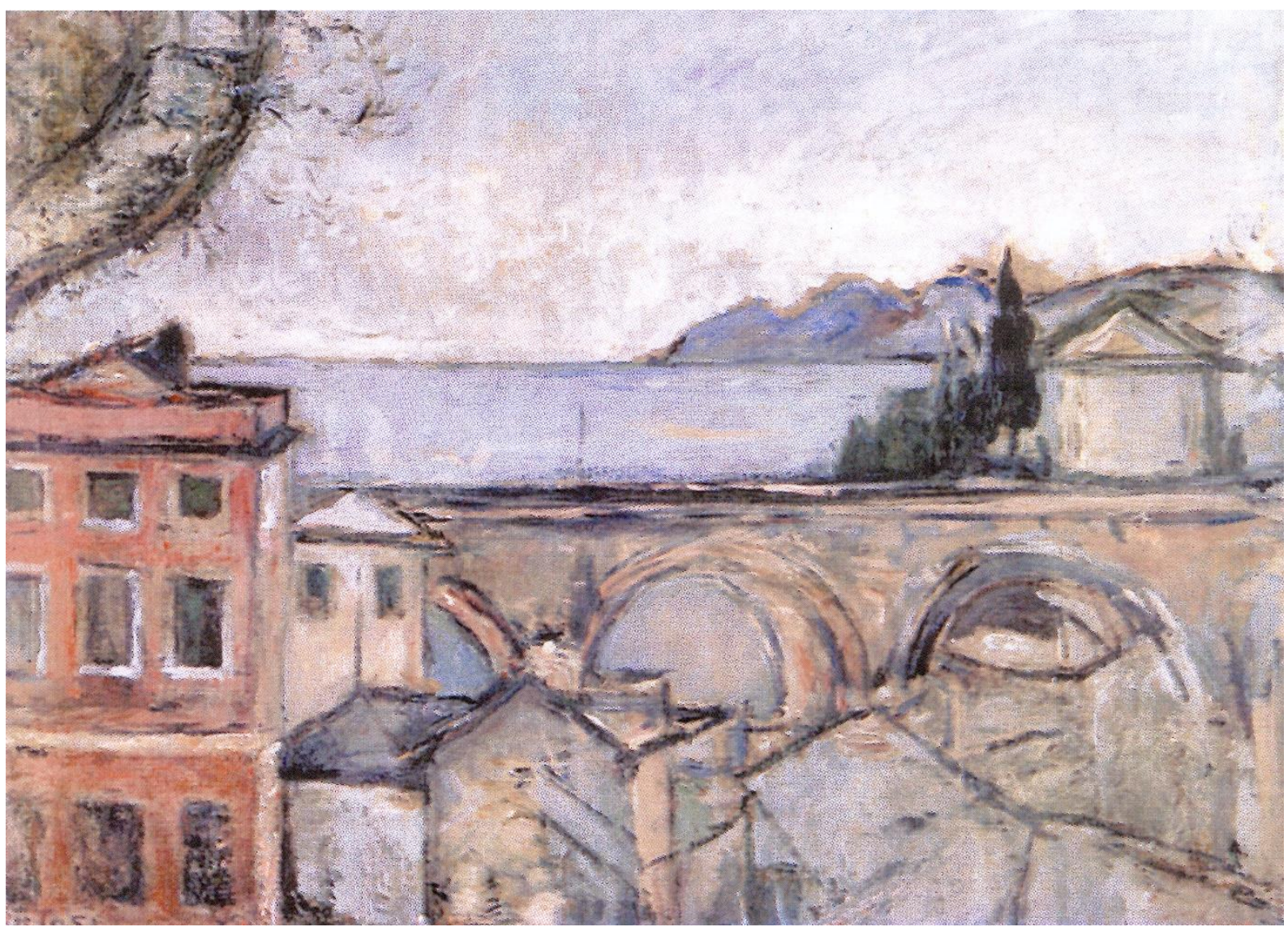

19 - Arturo Tosi, Ponte de Zoali, 1937;

70 x 90 cm, óleo sobre tela. São Paulo, Museu de Arte Contemporânea da USP. 


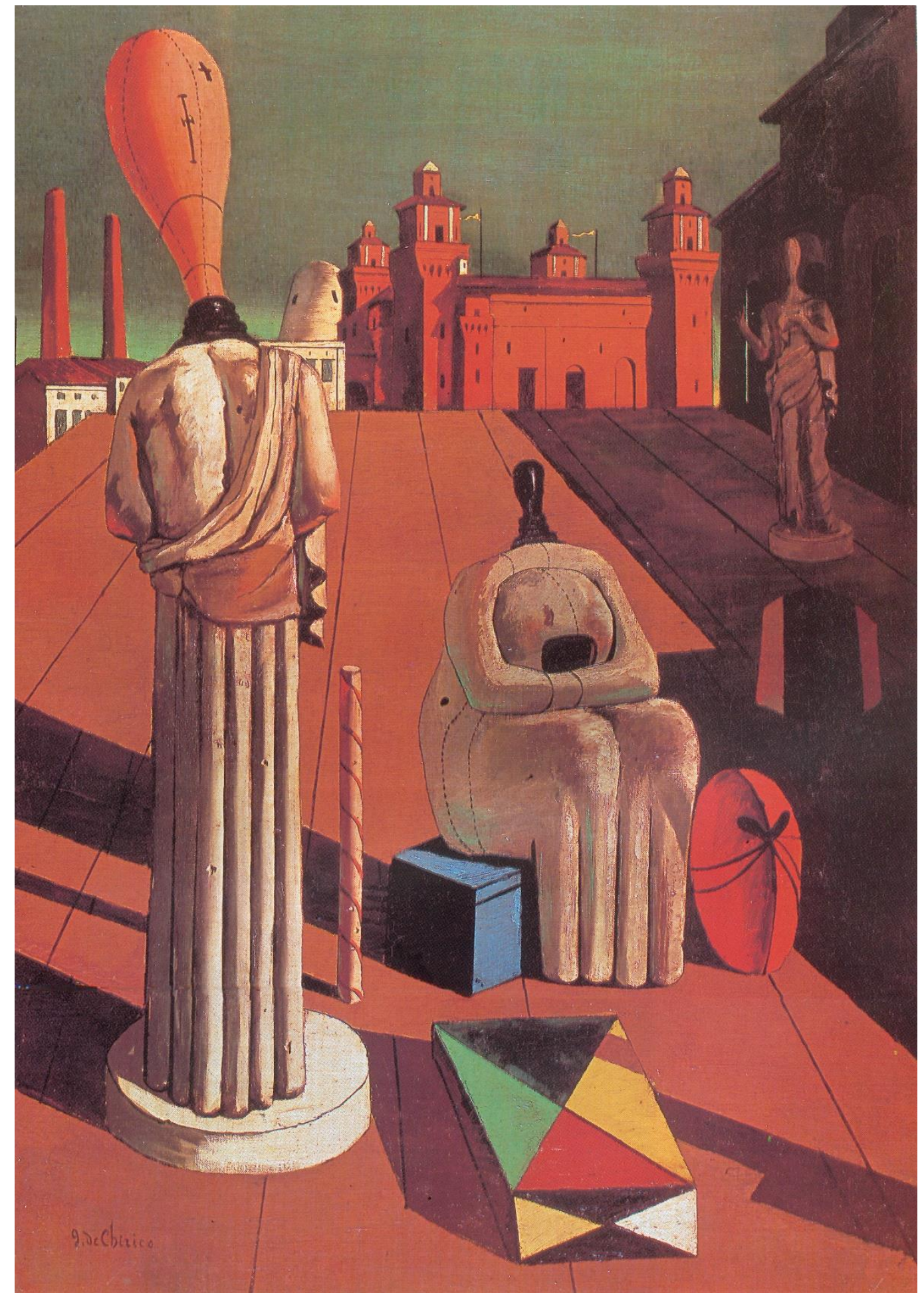

20 - Giorgio De Chirico, As Musas Inquietantes, 1916;

97 x 66 cm, óleo sobre tela. Milão, coleção particular de Arte Moderna. 


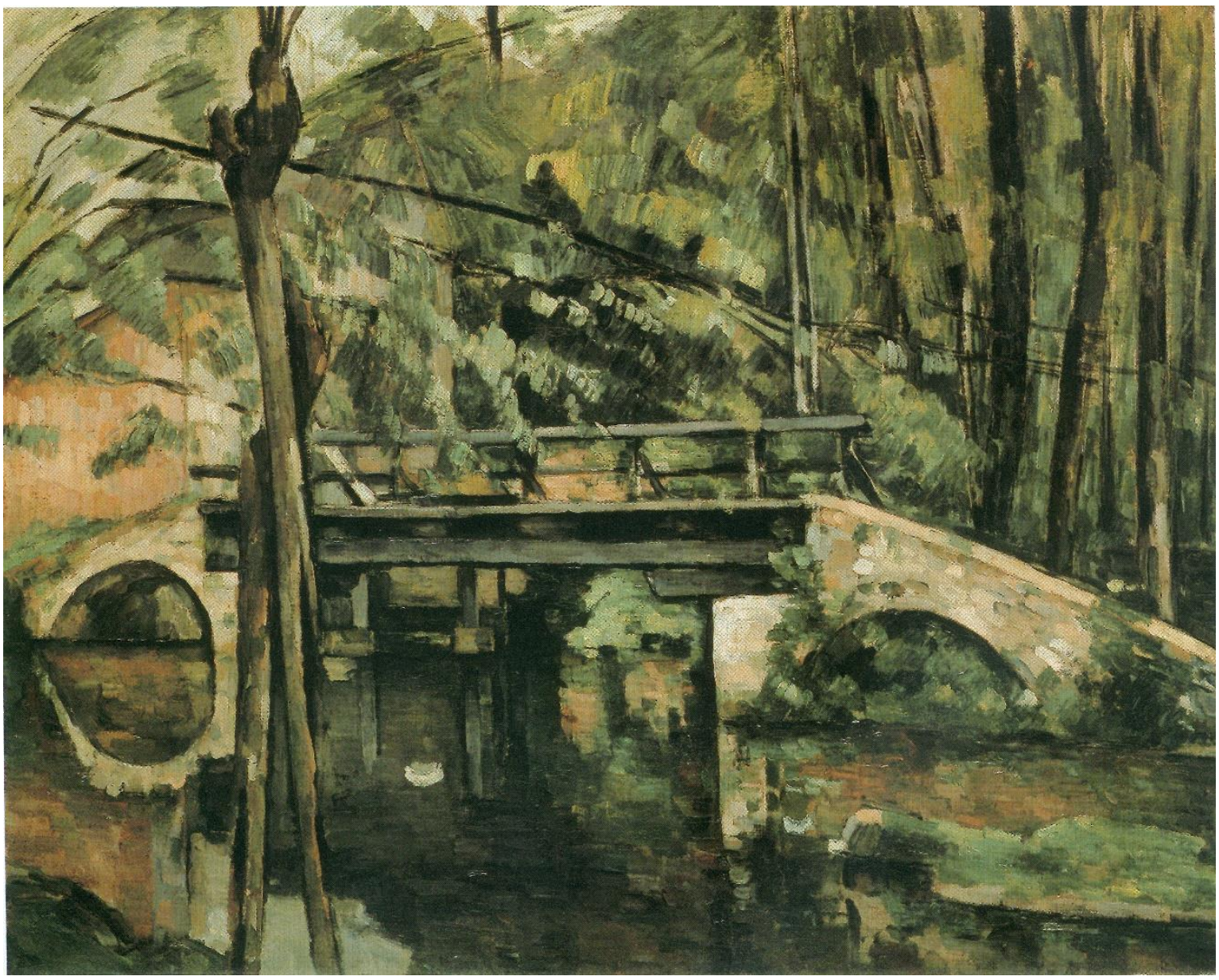

21 - Paul Cézanne, A Ponte de Maincy, 1879;

60 x 73 cm, óleo sobre tela. Paris, Musée d'Orsay. 


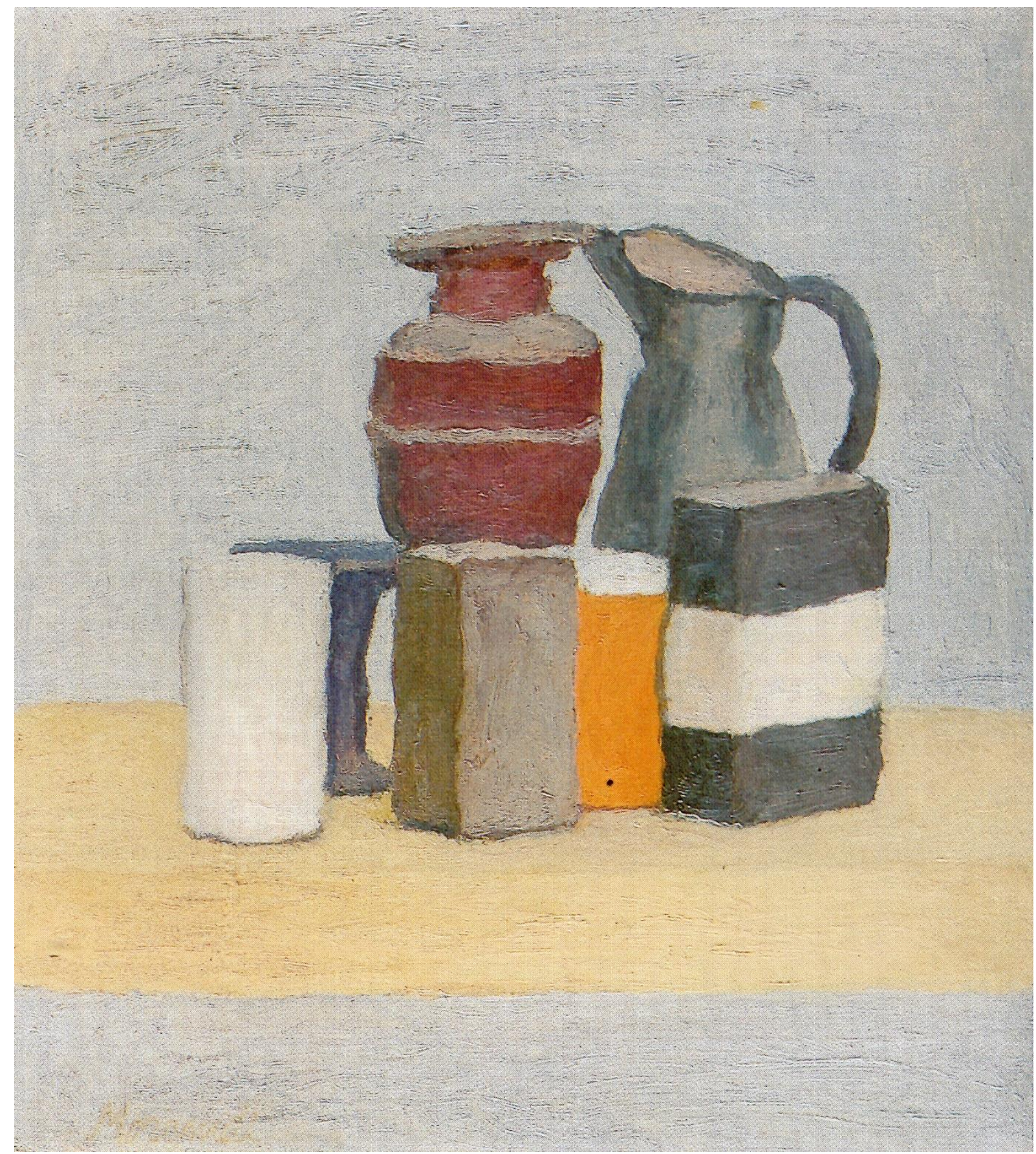

22 - Giorgio Morandi, Natureza-Morta, 1920;

38 x 35,5 cm, óleo sobre tela. Itália, coleção privada. 


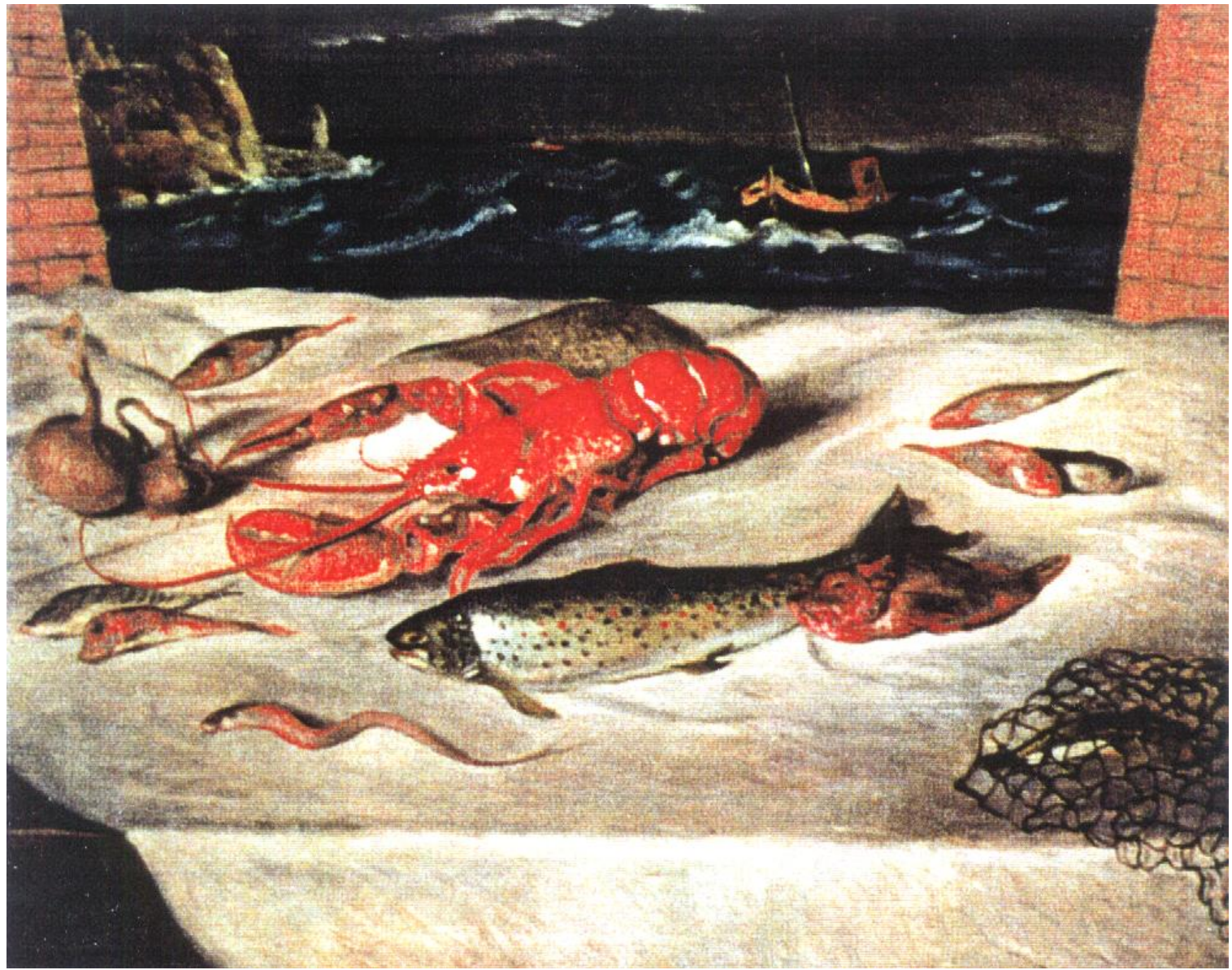

23 - Hugo Adami, Natureza-Morta com Lagosta, anos 30;

79 x 100 cm, óleo sobre tela. São Paulo, coleção Valéria Adami. 


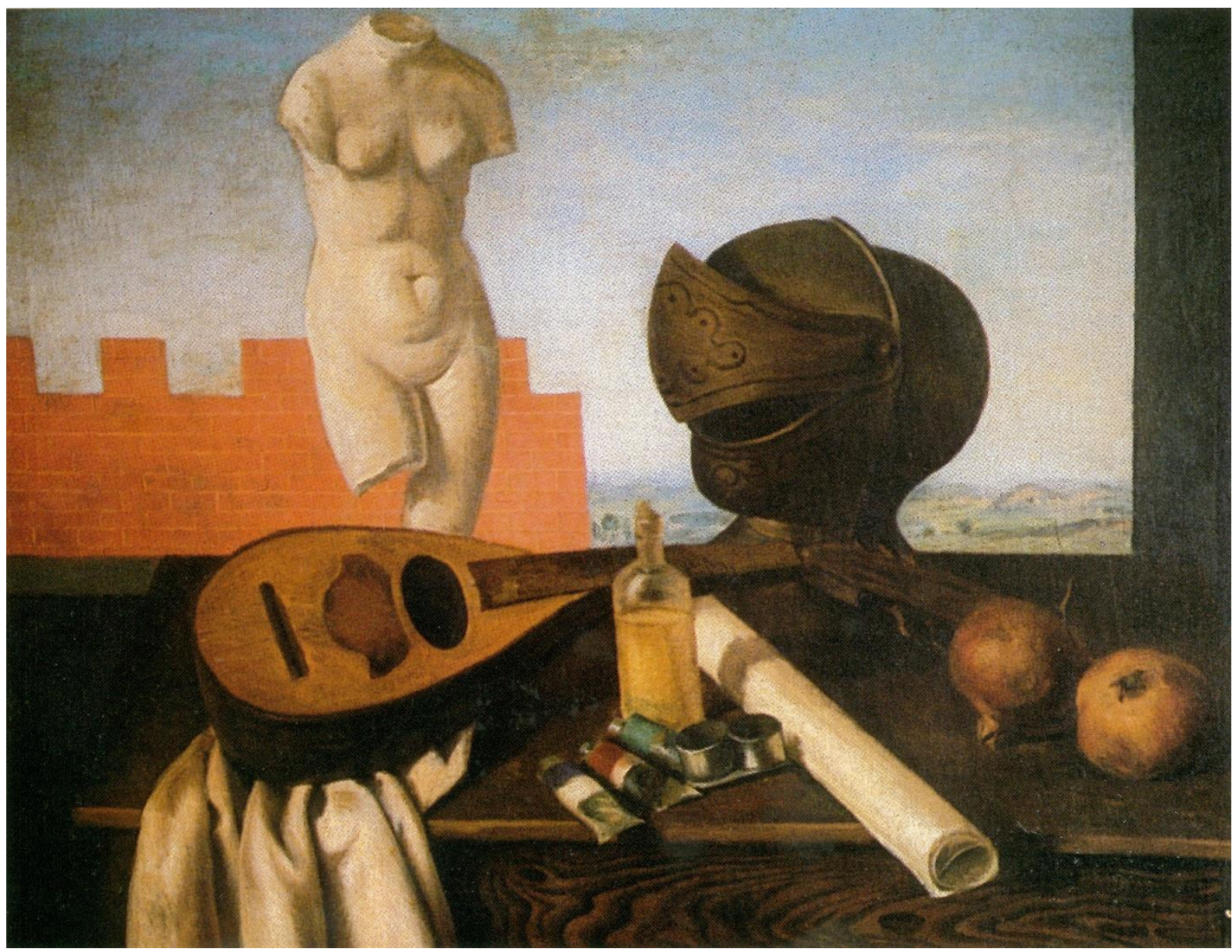

24 - Hugo Adami, As Artes, 1925;

82 x 101 cm, óleo sobre tela. São Paulo, coleção Adriana Adami. 


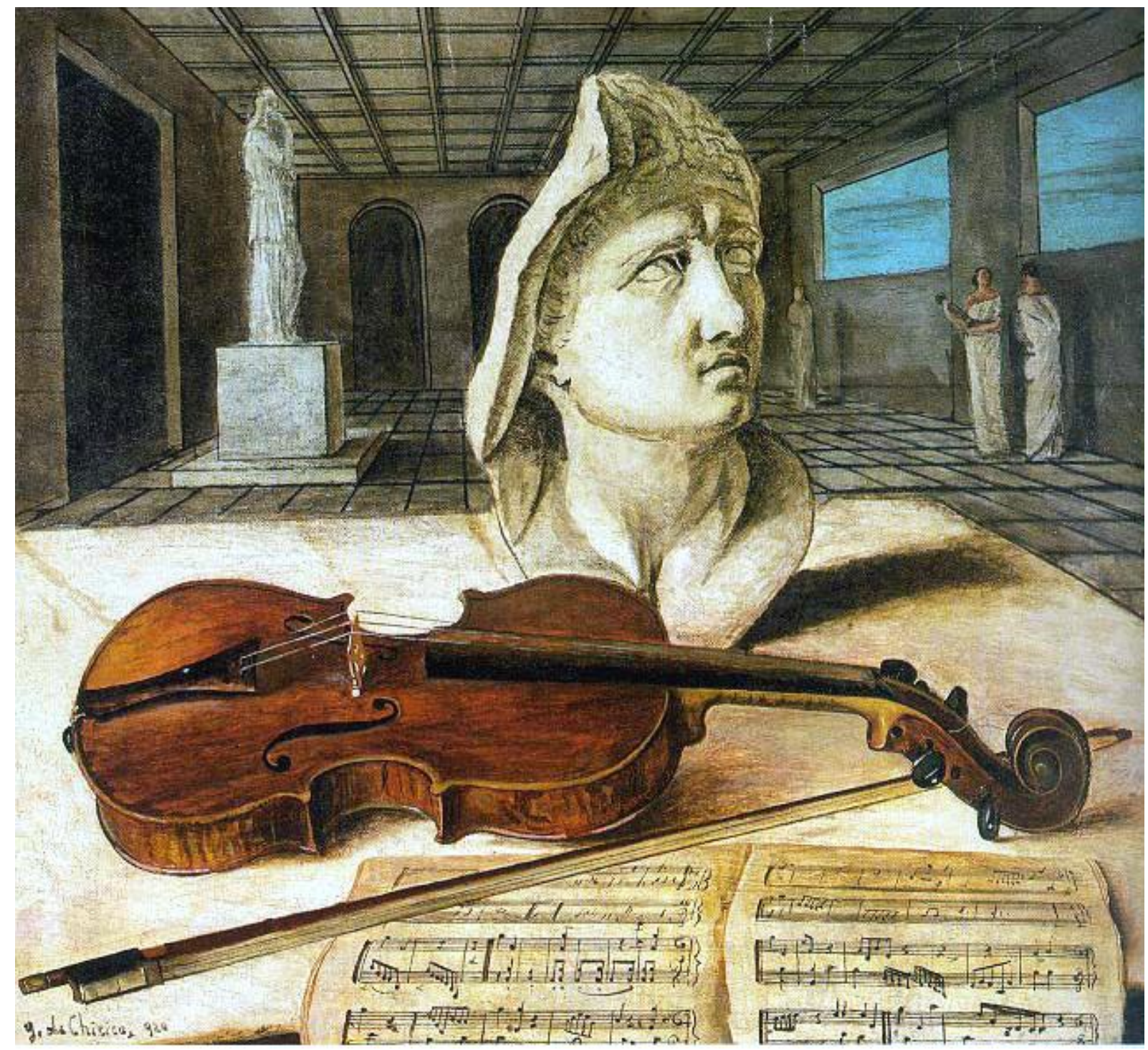

25 - Giorgio De Chirico, Sala de Apolo, 1920;

65 x $70 \mathrm{~cm}$, óleo sobre tela. Itália, coleção privada. 


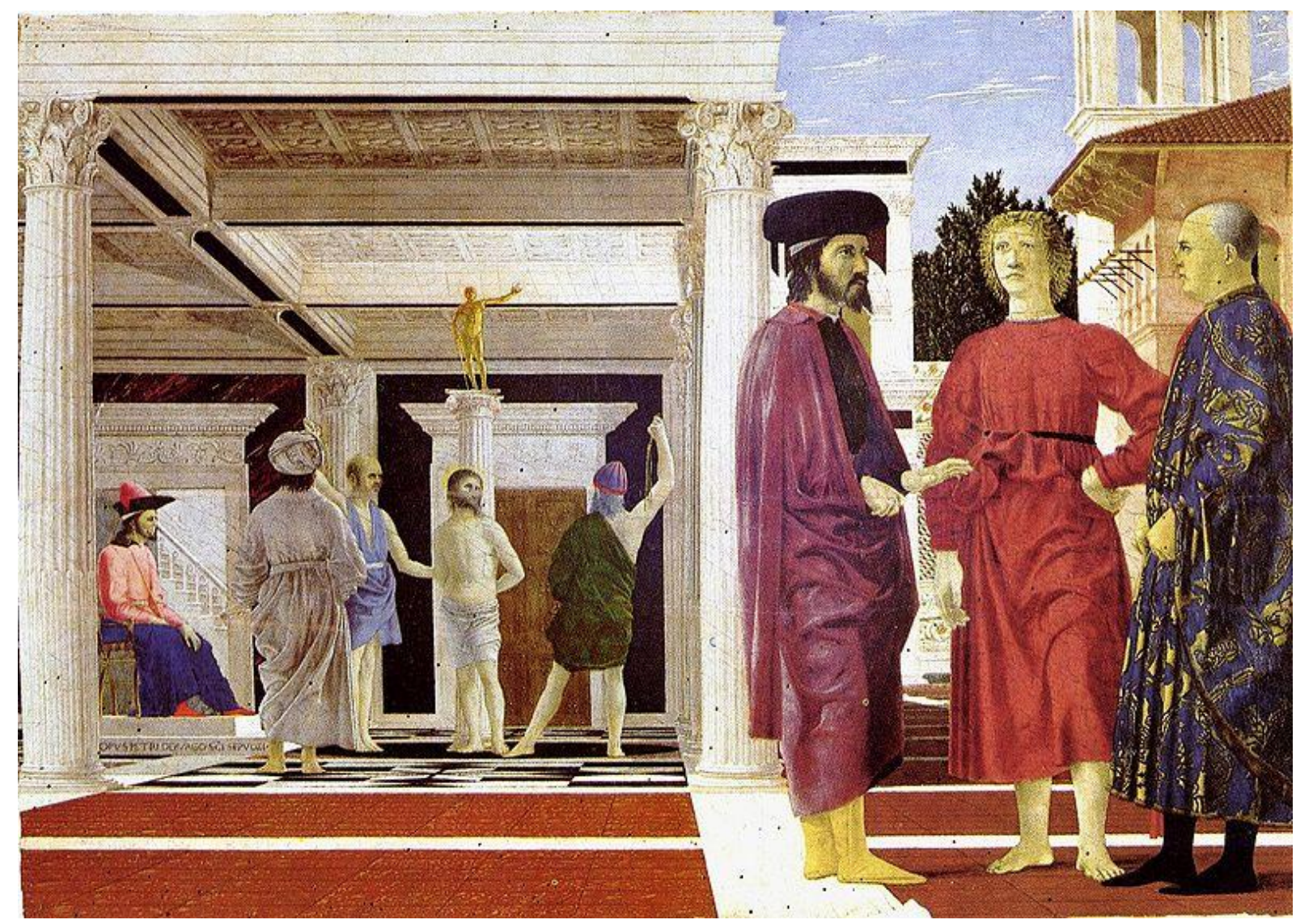

26 - Piero Della Francesca, Flagelação de Cristo, 1452;

59 x $81 \mathrm{~cm}$, têmpera sobre madeira. Urbino, Galeria Nacional. 


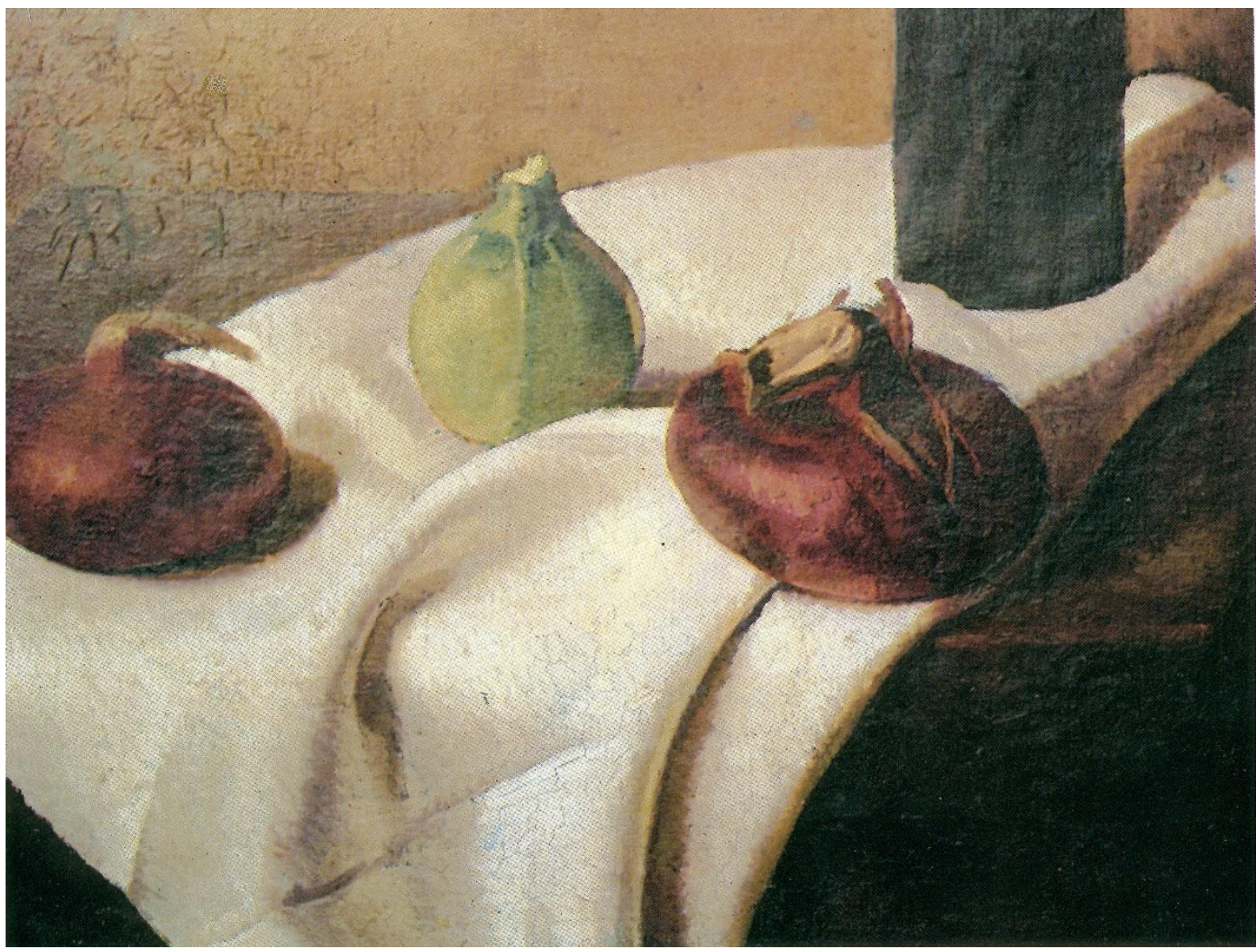

27 - Hugo Adami, Cebolas, 1926;

43 x 53,5, óleo sobre tela. São Paulo, Instituto de Estudos Brasileiros da USP. 


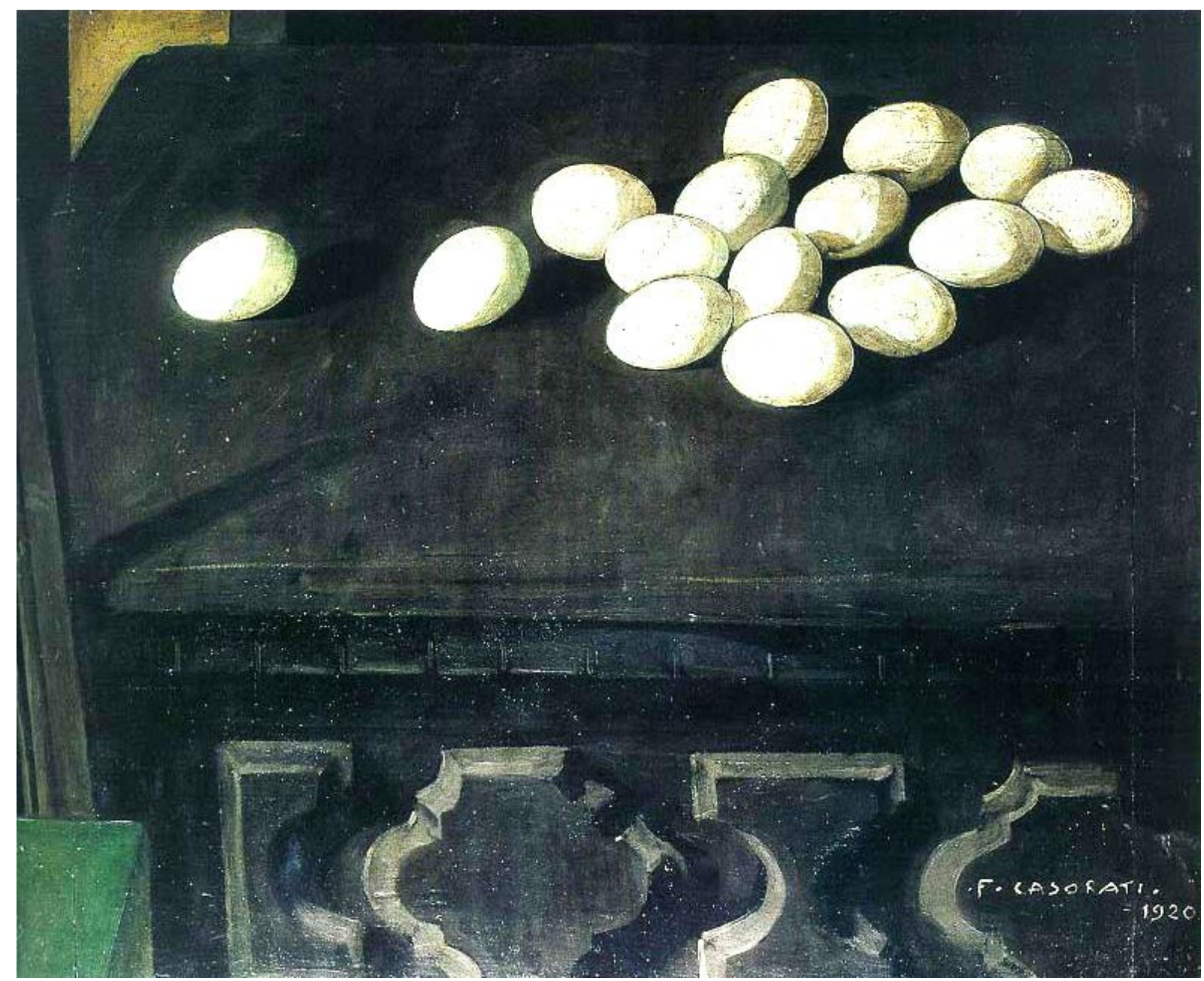

28 - Felice Casorati, Ovos sobre Baú, 1920;

48 x $63 \mathrm{~cm}$, têmpera sobre madeira. Turim, coleção privada. 


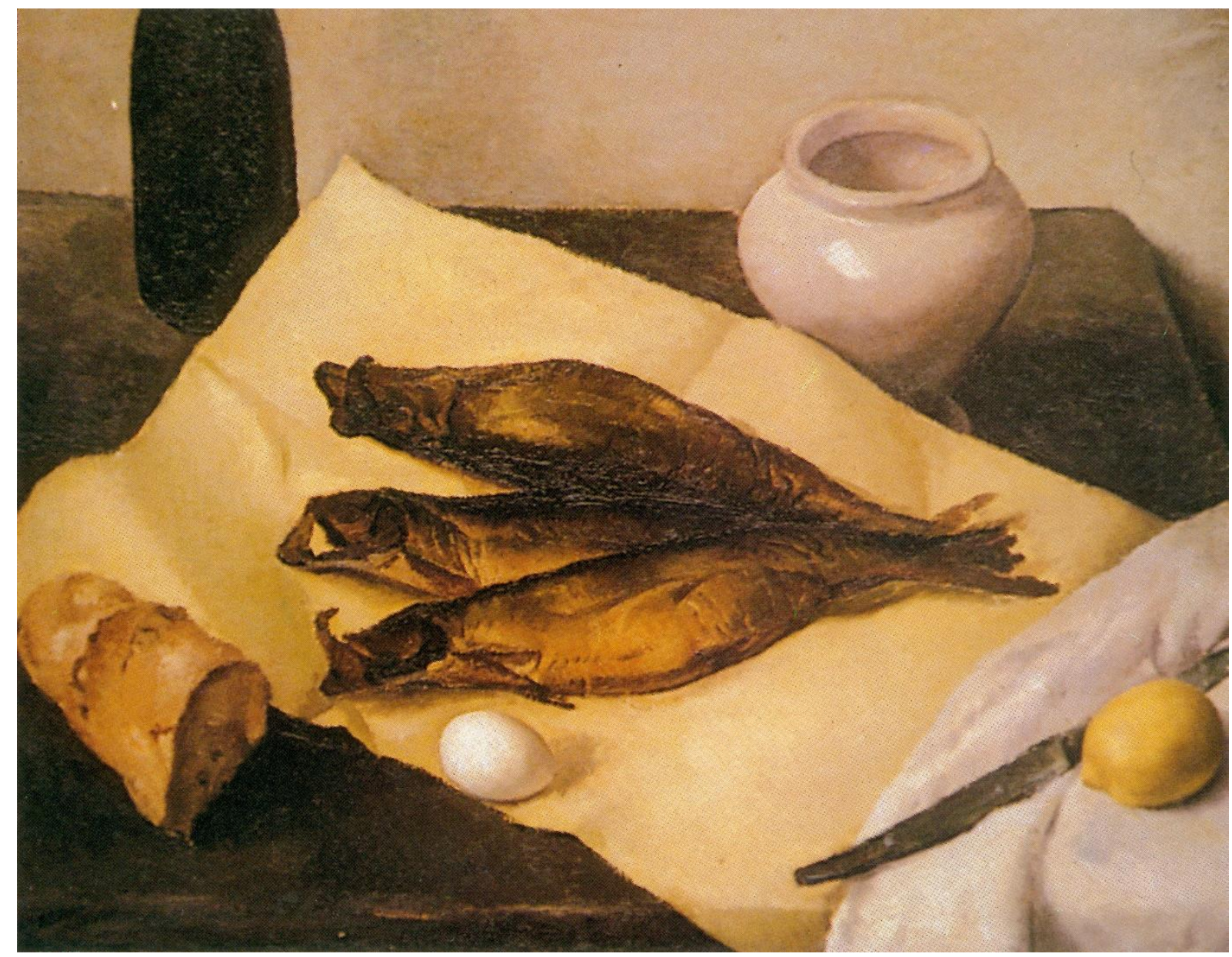

29 - Hugo Adami, Arenques Defumados, 1925;

57 x 70 cm, óleo sobre tela. São Paulo, coleção Fábio Ionescu. 


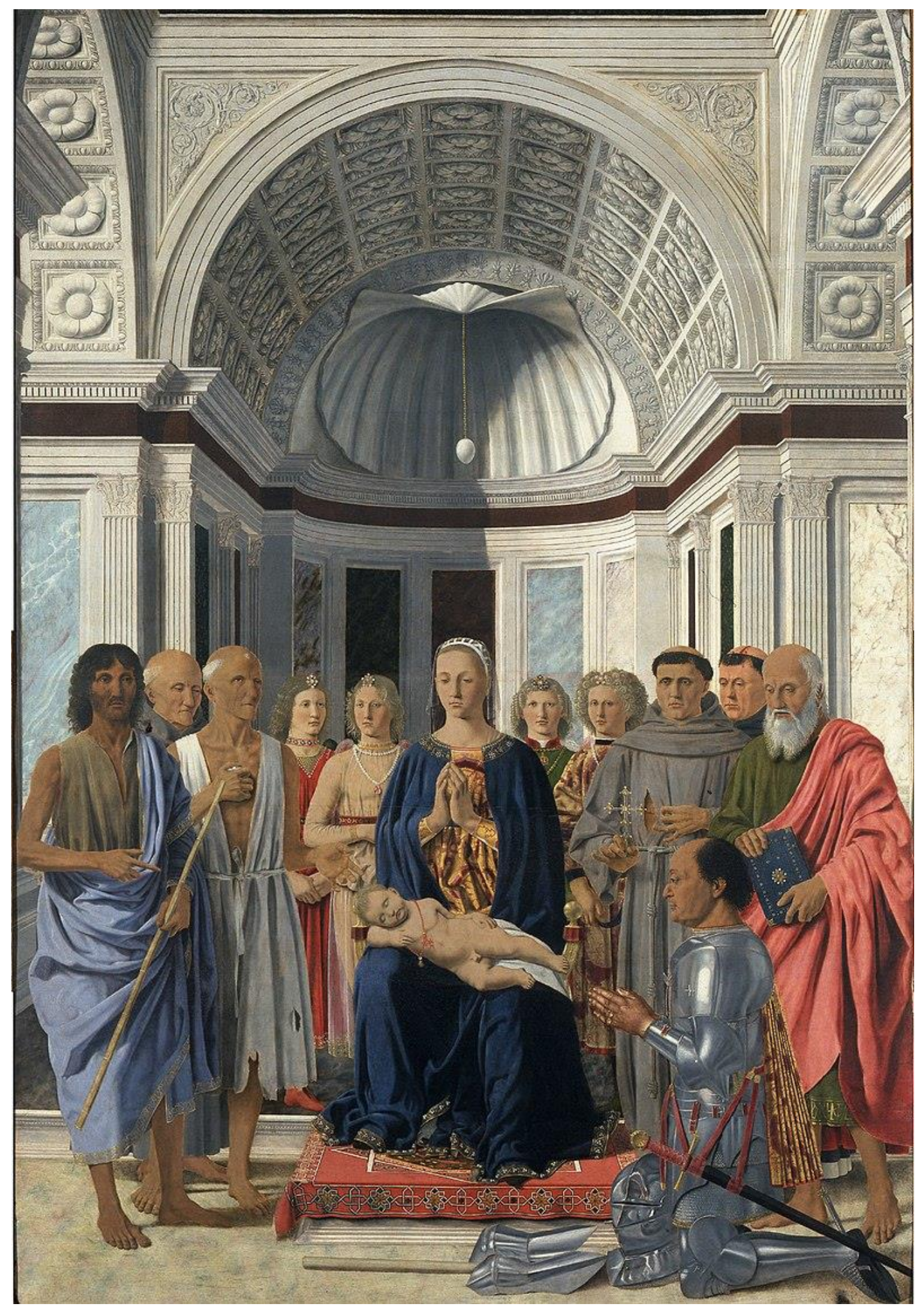

30 - Piero Della Francesca, Virgem e Santos com Federico da Montefeltro, 1470;

248 x 170 cm, têmpera sobre madeira. Brera, Milão. 


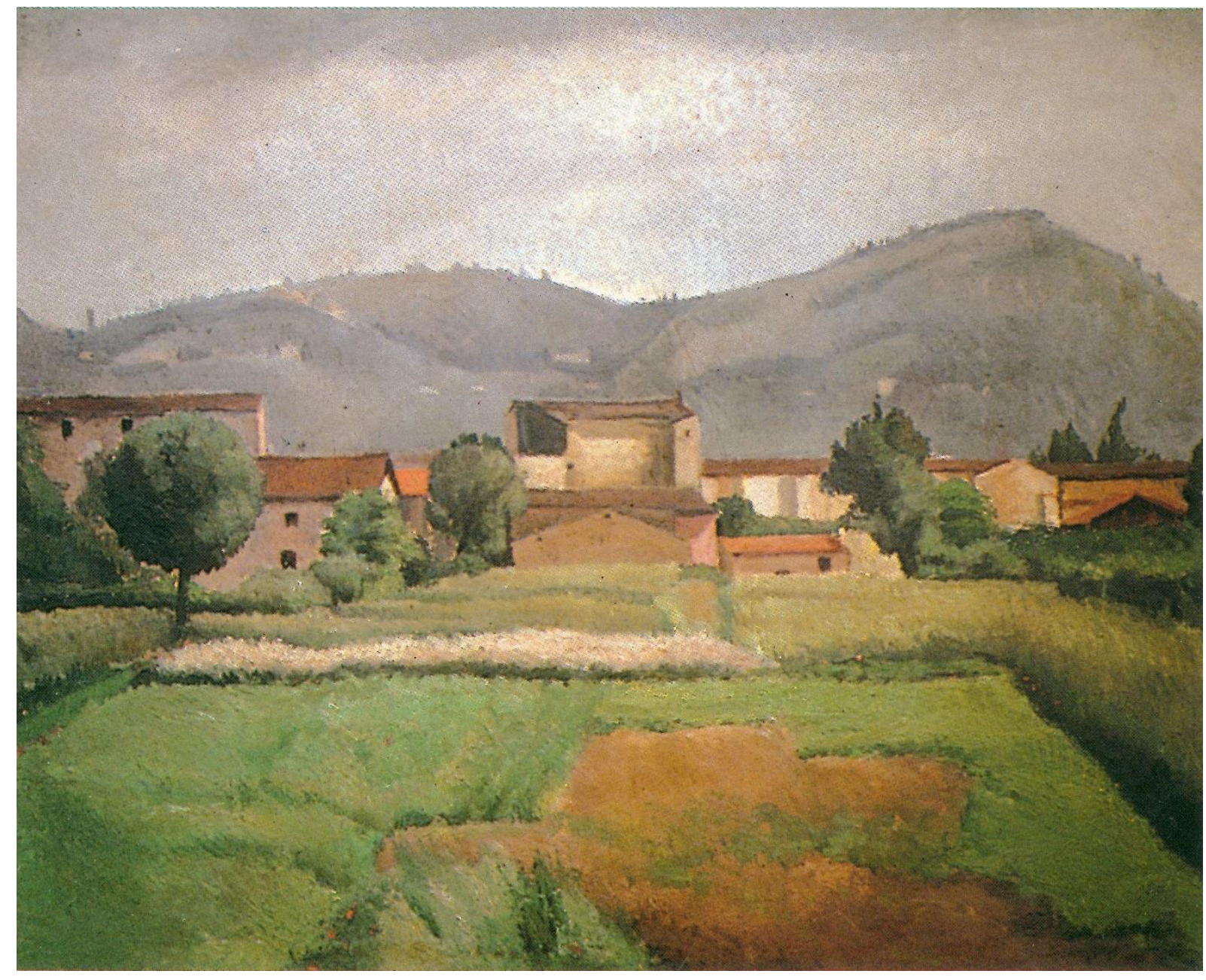

31 - Hugo Adami, Paisagem Toscana, 1927;

57 x 60 cm, óleo sobre tela. São Paulo, coleção Roberto de Nero. 


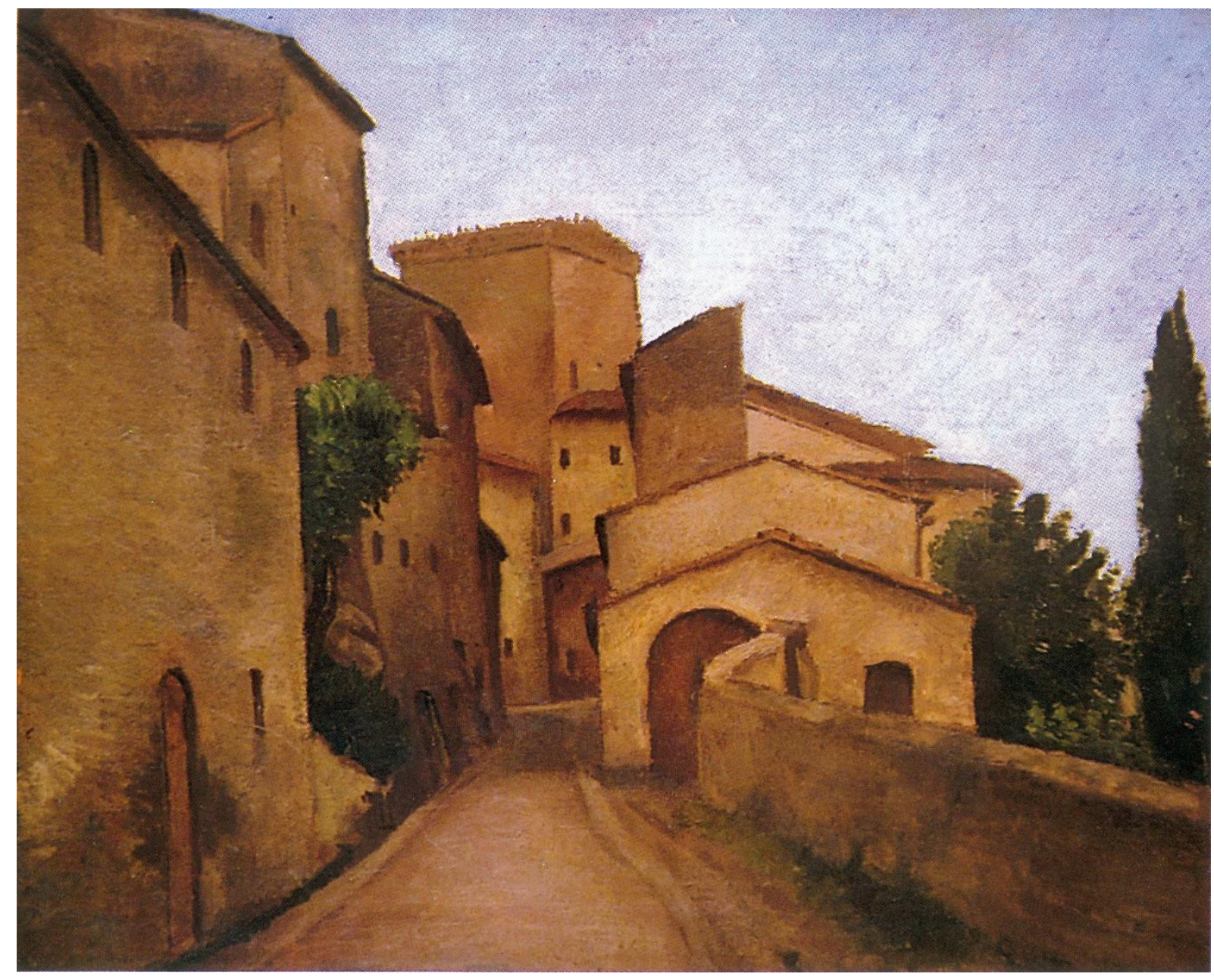

32 - Hugo Adami, San Giminiano (I), 1925;

57 x 70,5 cm, óleo sobre tela. Paradeiro ignorado. 


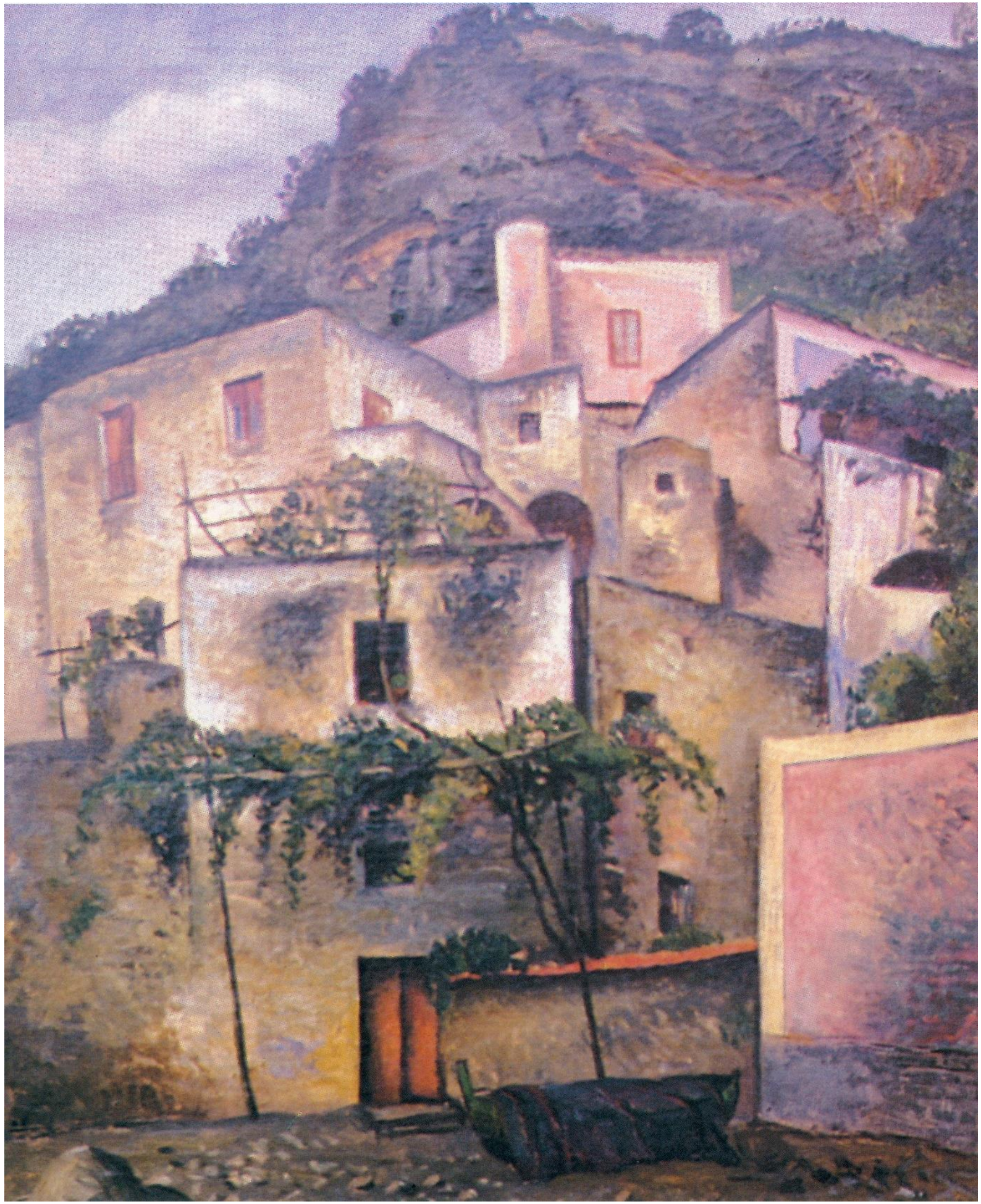

33 - Hugo Adami, Positano, 1933;

73 x 60 cm, óleo sobre tela. São Paulo, Museu de Arte Moderna. 


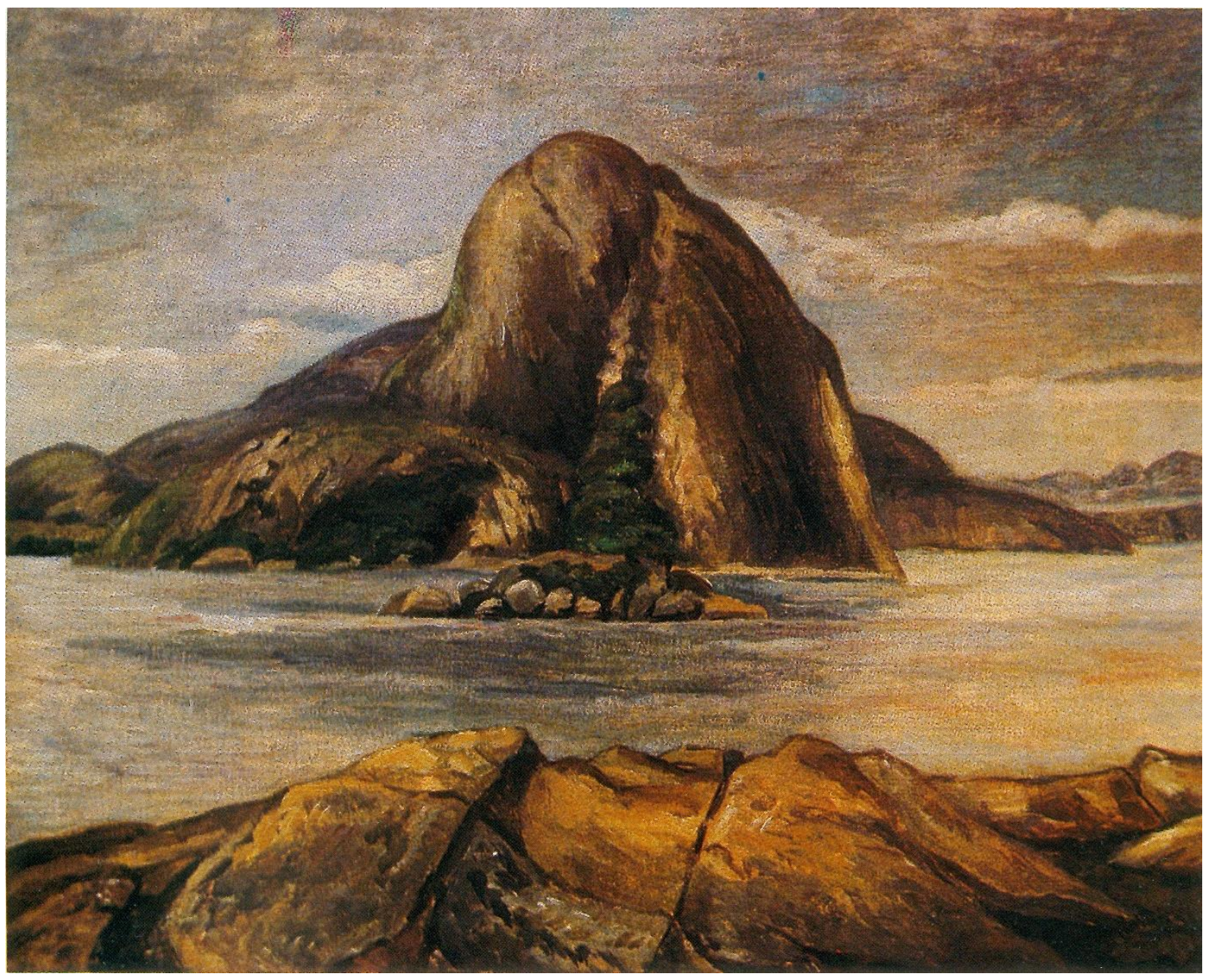

34 - Hugo Adami, Pico da Vitória, 1932;

54 x 65 cm, óleo sobre tela. São Paulo, coleção Roberto Ionescu. 


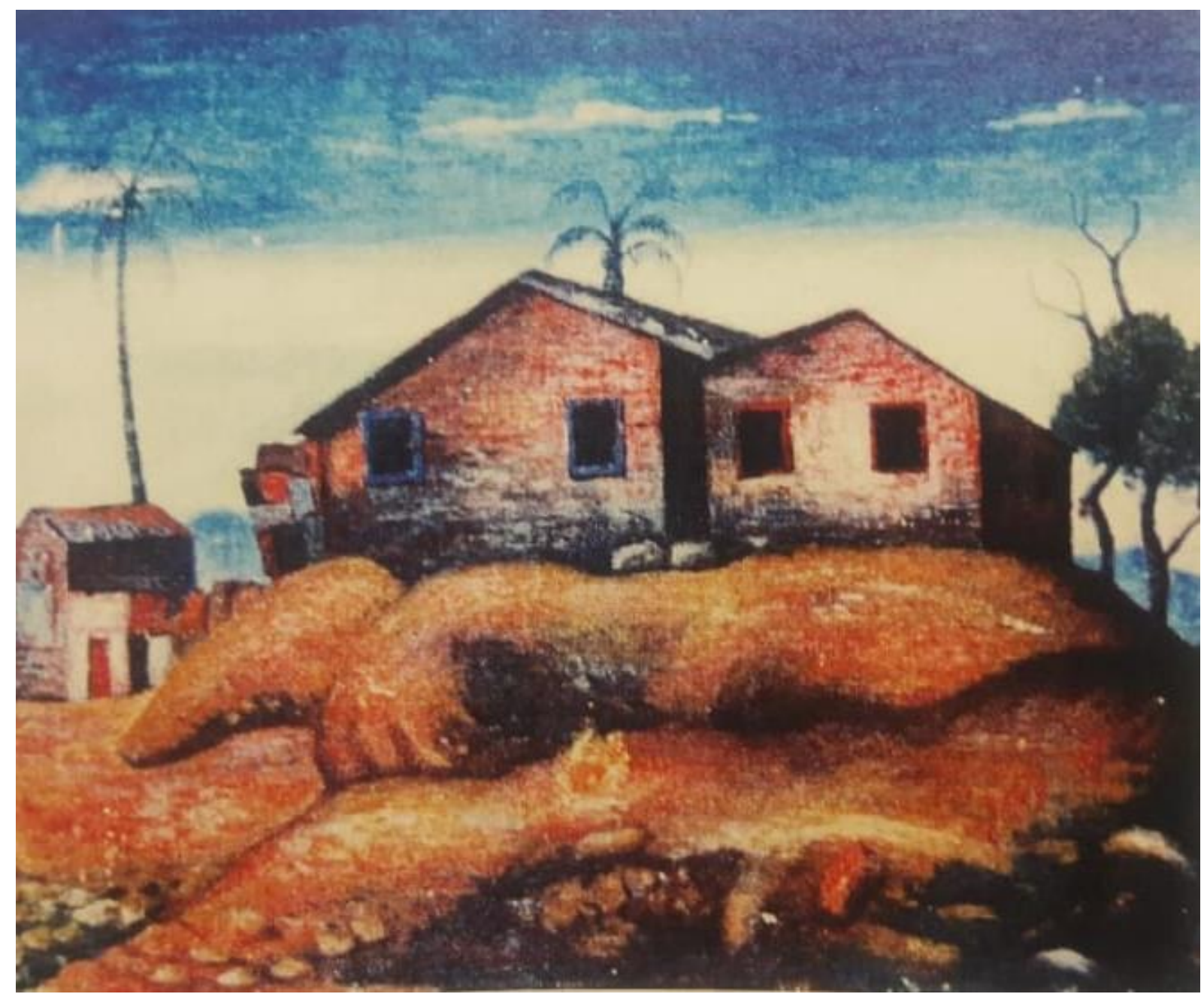

35 - Hugo Adami, Favela dos Meus Amores, 1930;

50 x 60, óleo sobre tela. São Paulo, coleção Sérgio Ademar e Edi Adami. 


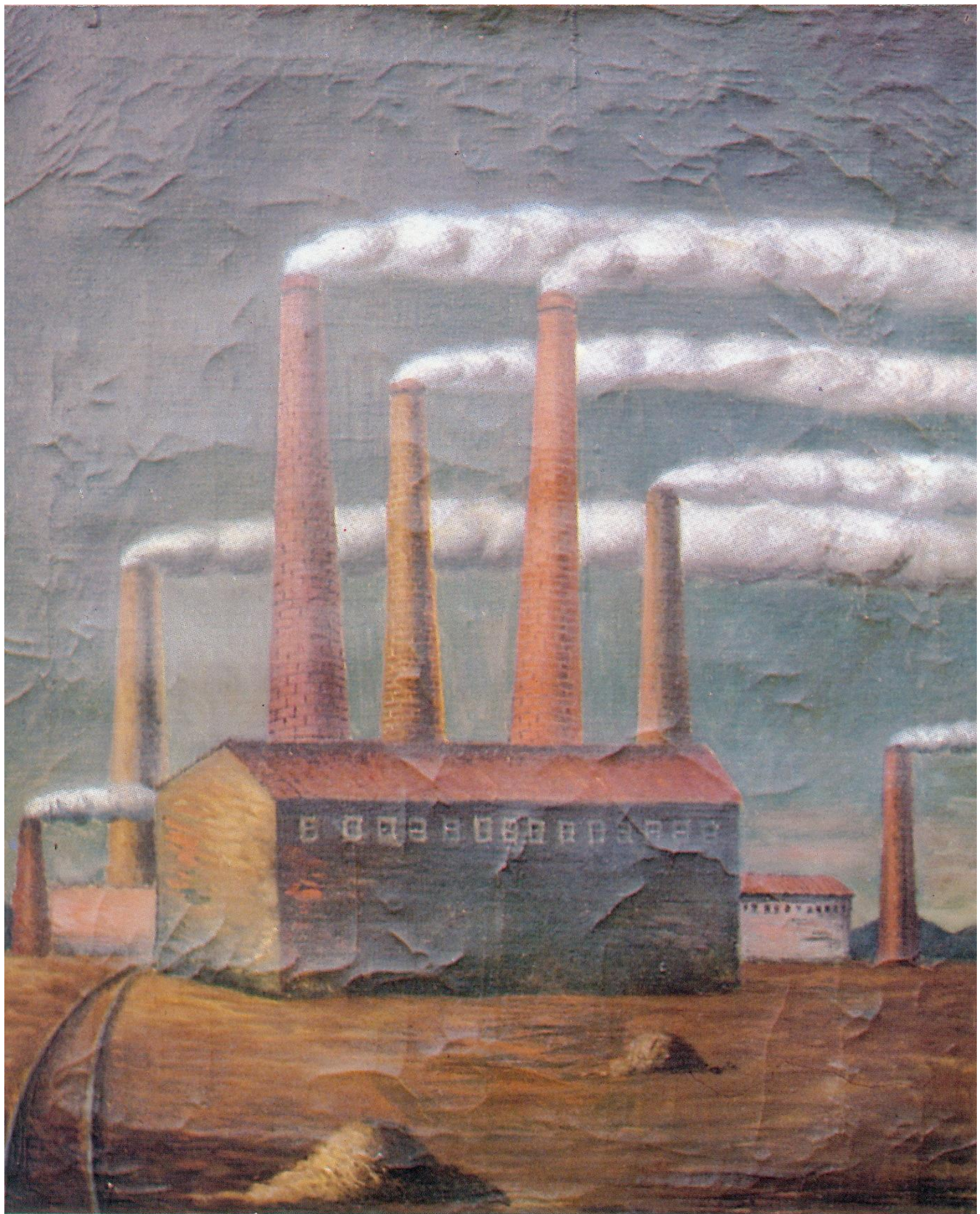

36 - Hugo Adami, Fábrica, 1934;

50 x 60 cm, óleo sobre tela. São Paulo, coleção Sérgio Ademar e Edi Adami. 


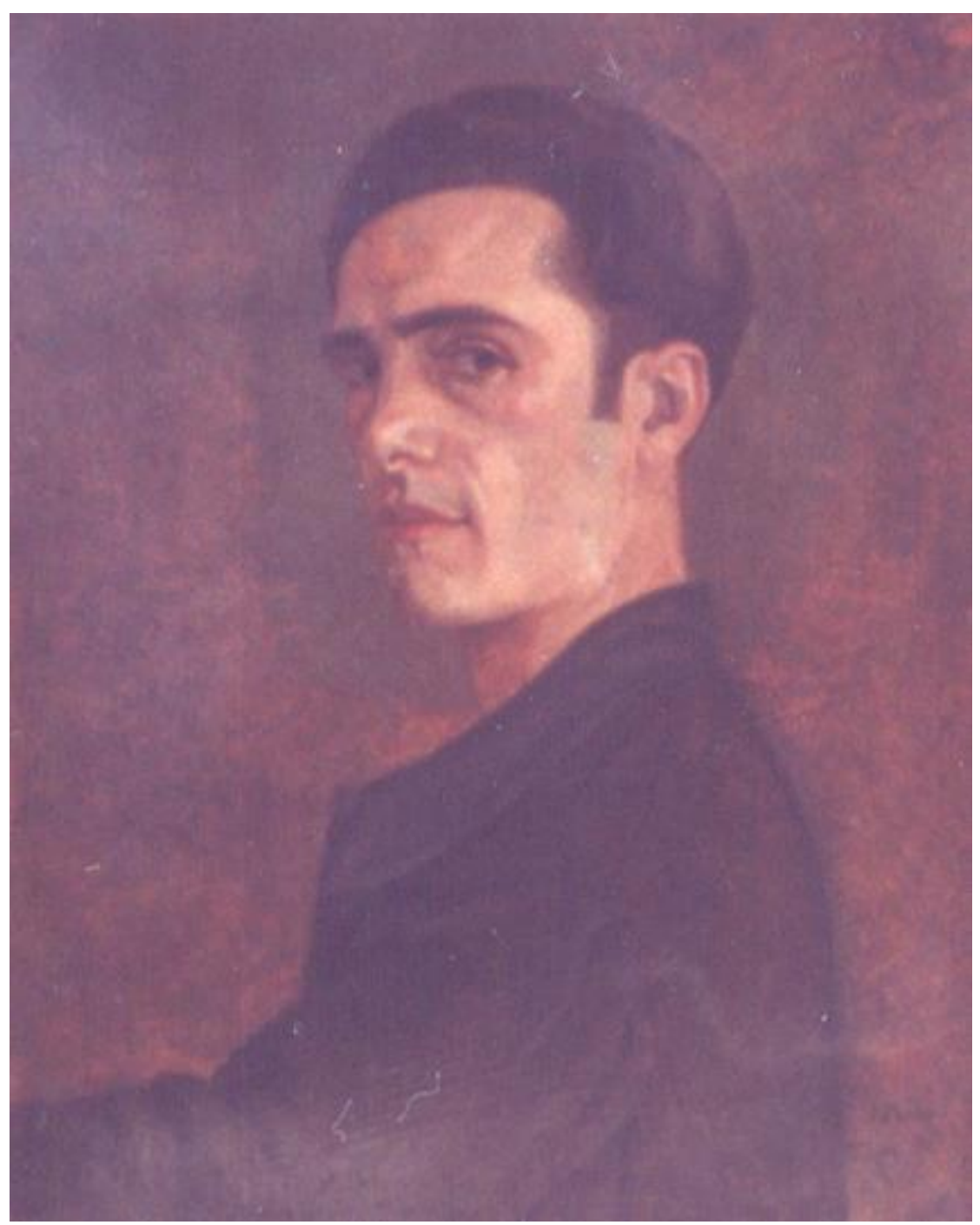

37 - Hugo Adami, Auto-Retrato, 1923;

61 x 50 cm, óleo sobre tela. São Paulo, coleção Geraldo Modesto. 


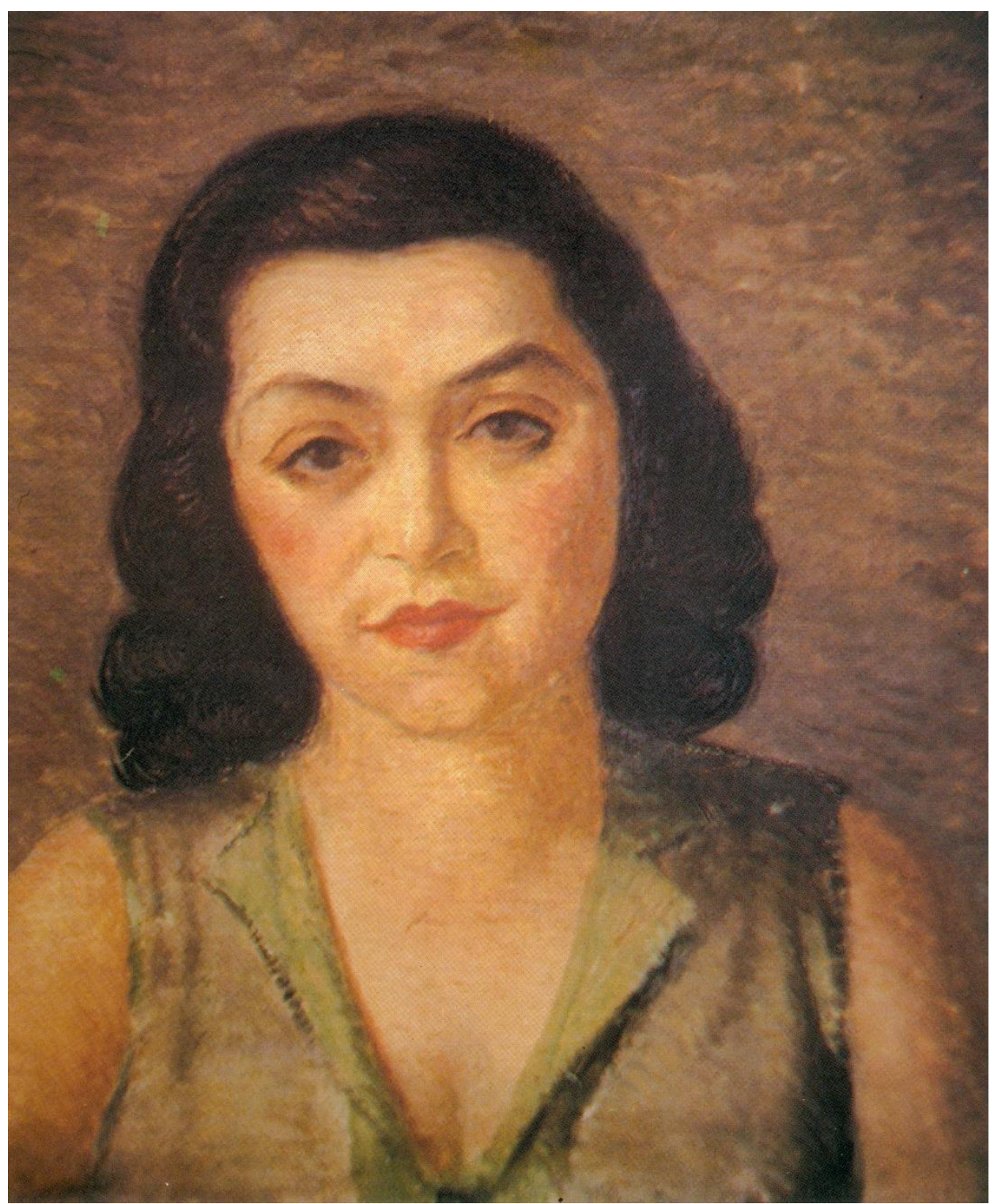

38 - Hugo Adami, Figura de Mulher, 1930-32;

65 x $54 \mathrm{~cm}$, óleo sobre tela. Paradeiro ignorado. 


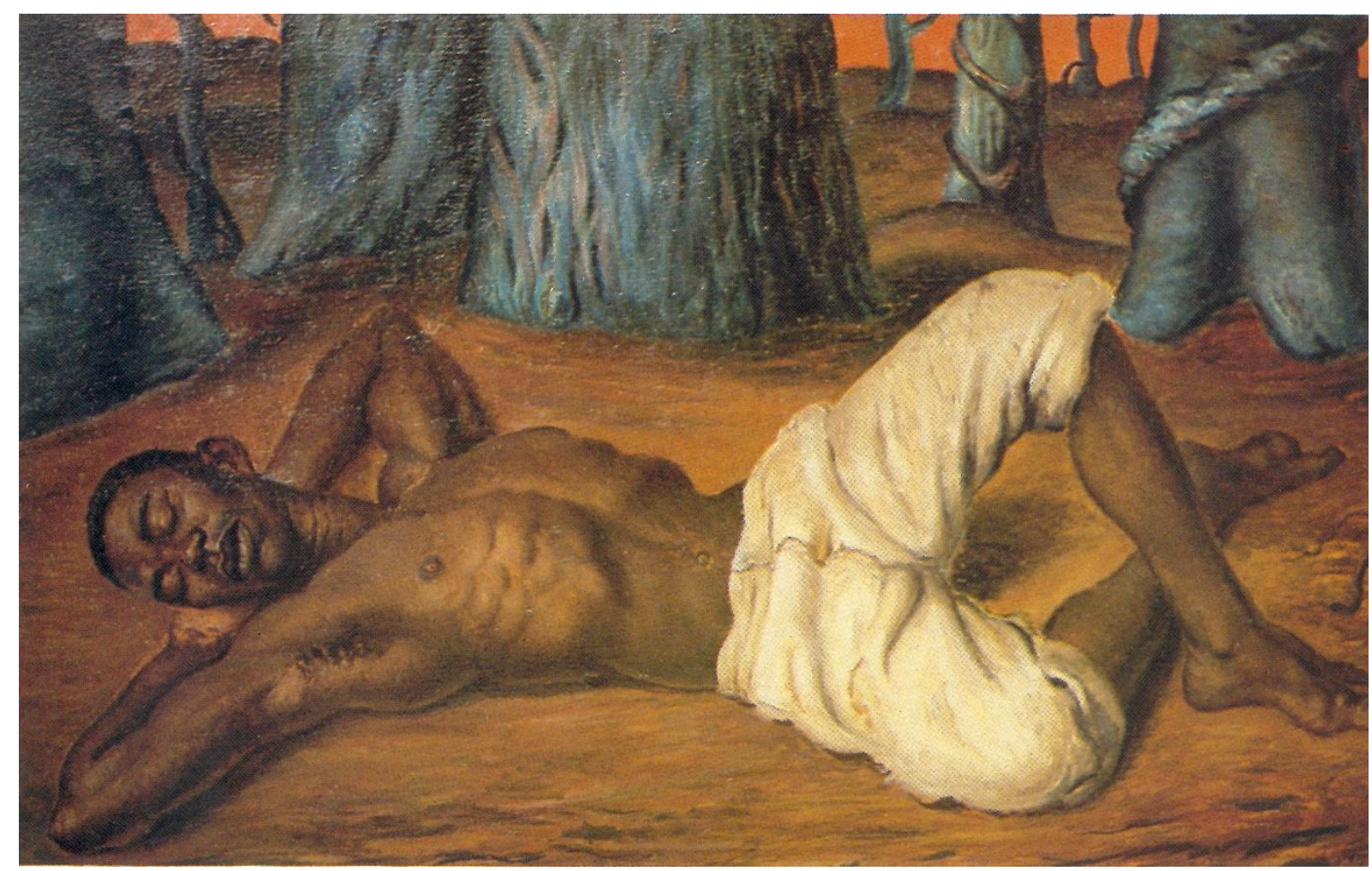

39 - Hugo Adami, Fugitivo, 1934;

98 x 148 cm, óleo sobre tela. Rio de Janeiro, Museu Nacional de Belas Artes. 